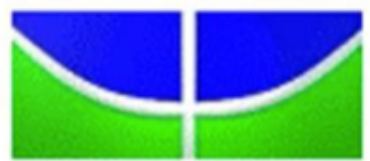

Universidade de Brasília

Universidade de Brasília - UnB

Instituto de Psicologia - IP

Programa de Pós-Graduação em Psicologia Clínica e Cultura PPG-PsiCC

A experiência de uma tv comunitária em saúde mental: do corpo invisível ao televisivo

Kéren Moreira de Alcântara

Brasília, DF

2015 


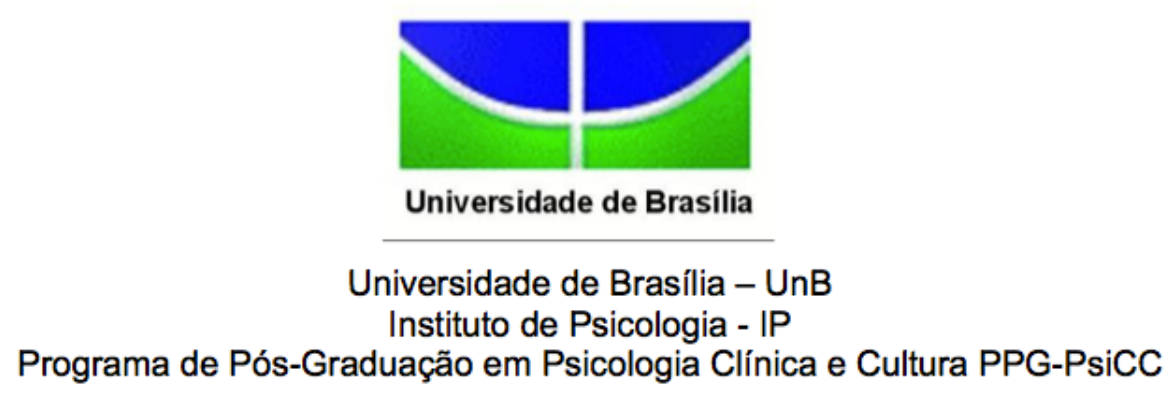

\section{A experiência de uma tv comunitária em saúde mental: do corpo invisível ao televisivo}

Kéren Moreira de Alcântara

Dissertação apresentada ao Programa de Pós-Graduação em Psicologia Clínica e Cultura do Instituto de Psicologia da Universidade de Brasília como parte dos requisitos para a obtenção do título de Mestre em Psicologia Clínica Cultura.

Orientador: Prof. Dr. Ileno Izídio da Costa

Brasília, DF

2015 
Alcântara, Kéren Moreira de.

A experiência de uma tv comunitária em saúde mental: do corpo invisível ao televisivo/ Kéren Moreira de Alcântara. Brasília: 0 autor, 2015.

$200 f$.

Orientador: Prof. Dr. Ileno Izídio da Costa.

Dissertação (Mestrado em Psicologia Clínica e Cultura) Instituto de Psicologa (IP), Universidade de Brasília (UnB).

Kéren Moreira de Alcântara 


\section{A experiência de uma tv comunitária em saúde mental: do corpo invisível ao televisivo}

Dissertação de Mestrado apresentada ao Programa de Pós-Graduação em Psicologia Clínica e Cultura do Instituto de Psicologia da Universidade de Brasília como parte dos requisitos para a obtenção do título de Mestre em Psicologia Clínica Cultura.

\section{Banca Examinadora:}

Prof. Dr. Ileno Izídio da Costa - Presidente da Banca - PsiCC/IP

Profa. Dra. Tatiana Lionço - Membro Externo - PED/IP

Profa. Dra. Elisa Walleska Kruger - Membro Externo - Personna/IP

Prof. Dra. Maria Inês Gandolfo - Membro Suplente - PsiCC/IP

Dissertação defendida e aprovada em

Brasília - DF

2015 
Dedico este trabalho ao Elias Batista. Ao compartilhar comigo sua vida, ele me mostrou que no caminho árduo da militância em saúde mental também é possível extrair a alegria da convivência. 


\section{Agradecimentos}

Ao Professor Dr. Ileno Costa.

Ao Professor Dr. José Bizerril.

À Professora Dra. Tânia Inessa.

Ao Conselho Nacional de Desenvolvimento Científico e Tecnológico (CNPq) pela concessão da bolsa de pesquisa durante o período de vigência dessa dissertação.

Ao Ministério da Cultura, pelo Programa de Intercâmbio e Difusão Cultural, por apoiar o projeto "Tv Loucura" desenvolvido em Porto, Portugal. 


\section{Resumo}

Percebe-se hoje no campo da saúde mental no Brasil certo movimento de politização protagonizado pelo "sujeito da desrazão". Esse grupo de usuários de saúde mental busca a extinção da lógica manicomial e a construção de uma sociabilidade nãohierárquica baseada na produção de instâncias coletivas que dão condições para que a saúde mental possa ser expressada livremente. Pensar o sofrimento psíquico hoje é inscrevê-lo num espaço criativo e inclusivo, portanto, o campo artístico-cultural representa mais que um potencial terapêutico, é um recurso de desenvolvimento político. Através da participação nas mídias comunitárias, de incapaz e irracional, o sujeito passa a ocupar a posição de protagonista, desejante, construtor de projetos, cidadão que participa e interfere no campo político. No intuito de explorar novos caminhos desinstucionalizantes, essa pesquisa teve como foco de estudo a atuação do Núcleo de Comunicação Comunitária em Saúde Mental no DF, grupo denominado Tv Sã. Esse trabalho teve como objetivo analisar as possíveis contribuições da tv comunitária no campo da saúde mental a partir dos discursos de seus participantes. Foi utilizada a metodologia de análise do Discurso do Sujeito Coletivo (DSC) associada ao software Qualiquantisoft que permitiu ordenar as entrevistas do grupo focal, sistematizar as informações e transformá-las em um discurso síntese. A Tv Sã mostrou-se um importante instrumento para a cidadania. É possível concluir que a filosofia de trabalho desse grupo rompe com a lógica do isolamento e estabelece vínculos de afetividade entre os membros; substitui o sujeito da razão pelo sujeito da criação capaz de tocar as pessoas por meio de suas produções; amplia o campo de visibilidade publicamente reconhecido e valoriza a democratização da comunicação pela expressão da diversidade humana. É um espaço em que a figura desumanizada do louco é desfeita e se constrói em seu lugar o sujeito da diferença enquanto sujeito de direitos. Tornar o invisível televiso é legitimar outros modos de ser, questionando as formas opressivas de convivência. A tv comunitária e o trabalho coletivo é, portanto, mais que um espaço de saúde, é um espaço de cultura e de transformação, é um espaço de produção de vida que indica novos caminhos de desinstitucionalização, caminhos de liberdade.

Palavras-chave: tv comunitária, saúde mental, cidadania, desinstitucionalização. 


\begin{abstract}
Currently, there is a movement of mental health in Brazil which is protagonized by those who are considered insane. The clients of mental health services want the end of the manicomial logic. Besides, they propose the construction of a non-hierarchical sociability based on the production of collective instances which give conditions for their subjective can be expressed freely. Today, we should consider creative and inclusive spaces in order to think about mental suffering. So, the artistic and cultural fields represent more than a therapeutic potential, it is a political and developmental resource. The participation in communitarian TV networks proves it is possible to transform the subject's representation: inefficient and irrationality are taking apart when they start to occupy the leading role, discovering theirselves and their desires, their potenciality to build new projects and to be a citizens who participate and interfere on the political field. Searching for new ways to produce life in a noninstitutionalized form, the goal of this study is researches the work of the Center of Communitarian Tv in Mental Health in Distrito Federal, called Tv Sã. This study aimed to analyze the speeches of the participants in order to realize the possible contributions of this communitarian $\mathrm{Tv}$ in the field of mental health. It used the analysis's methodology of the Collective Subject Discourse (CSD) associated with a Qualiquantisoft software which allowed the organization of the information from the focus group interviews and transform them into a speech synthesis. It is possible to conclude that TV Sã is an important instrument for citizenship. The philosophy's work of this group is: to break with the logic of isolation, to establish affective ties among the members; to replace the subject of reason by the subject of creation able to touch people through their productions; to extend the publicly recognized field of vision and to value the democratization of communication for the expression of human diversity. It is a space where the dehumanized figure of mental disorder is undone and is built in its place the subject of difference as a subject of rights. In conclusion, make the invisible be televisible is legitimize other ways of being, questioning the oppressive ways of living. The communitarian $\mathrm{Tv}$ and the collective work is more than a health space, is a space of culture and transformation, is a space of production of life in a perspective non-institutionalized. That's ways of freedom.
\end{abstract}

Key-words: communitarian Tv, mental health, citizenship, non-institutionalized. 


\section{Sumário}

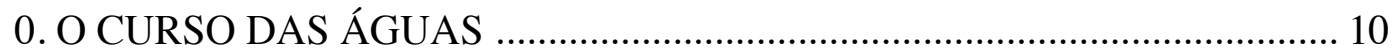

1. A NAU DOS LOUCOS: UMA VIAGEM SEM VOLTA? ............................. 13

1.1 - O Prisioneiro da Passagem ........................................................................ 13

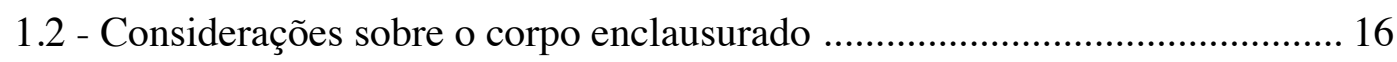

1.2.1 - A espacialidade ..................................................................... 22

1.2.2 - A temporalidade .................................................................... 26

2. DIVISÃO DE MARES: O MUNDO DA RAZÃO/DESRAZÃO ..................... 32

2.1 - Pathos: os efeitos dos afetos negados ....................................................... 32

2.2 - A crise da Razão e o declínio da modernidade ............................................ 40

2.3 - Colonialidade, modernidade e manicomialidade ....................................... 47

2.3.1 - A construção da cidadania no Brasil .............................................. 55

2.3.2 - Cidadania alienada: o sujeito de direitos é o sujeito do dinheiro ... 61

2.3.3 - Desconstrução, desinstitucionalização e desalienação ................... 71

2.4 - A reforma psiquiátrica brasileira e a presença da manicomialidade ............. 78

2.4.1 - As especificidades da reforma psiquiátrica brasileira ................... 79

2.4.2 - Os desafios da desinstitucionalização no plano sociocultural ........87

3. O DIREITO DE COMUNICAR A DIVERSIDADE ................................... 93

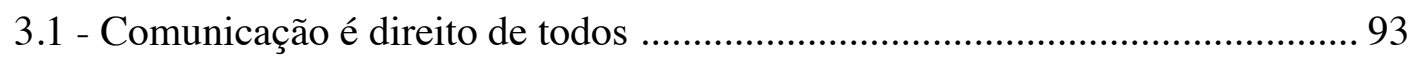

3.2 - Comunicação comunitária e saúde mental ................................................. 96

3.3 - Escutando as vozes: a proposta de uma tv comunitária em Saúde Mental ... 100

3.3.1 - Tv Pinel: por uma nova imagem da loucura ................................ 100

3.3.2 - ONG Inverso: espaço de re-criação ............................................. 101

3.3.3 - A experiência da Tv Sã .............................................................. 103

3.3.4 - As produções áudio-visuais do grupo ........................................... 106

3.3.5 - O processo de construção de um vídeo .......................................... 114

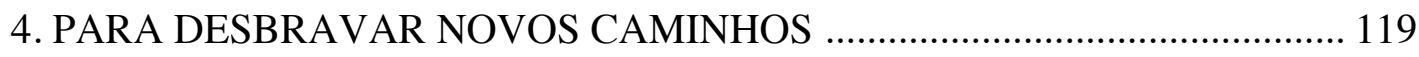

4.1 - Aspectos éticos e metodológicos da pesquisa ................................................. 119

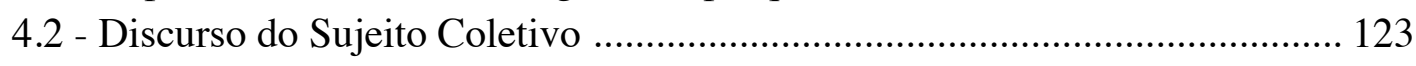

4.2.1 - O Software Qualiquantisoft ....................................................... 125

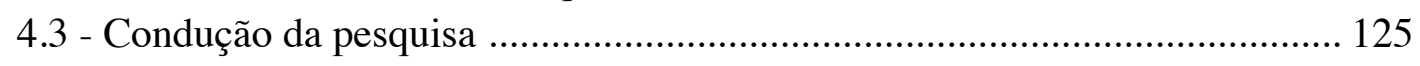

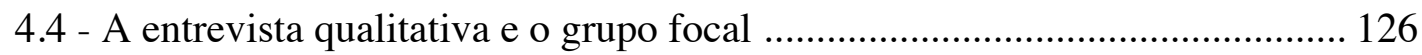

4.5 - Análise sobre a dinâmica da entrevista grupal ............................................ 127

4.6 - O Discurso Coletivo da Tv Sã .................................................................... 139

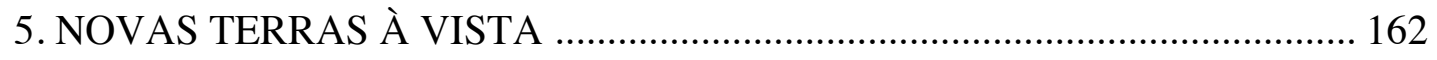

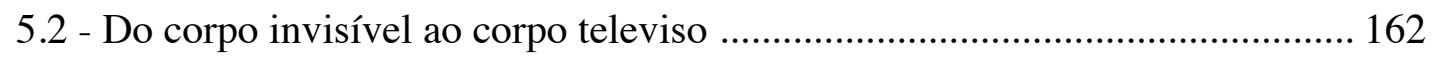

5.3 - Cidadania ampliada: uma construção coletiva ............................................ 167

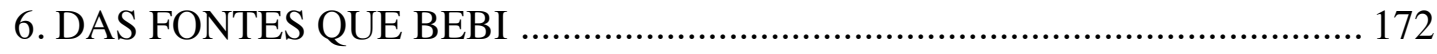

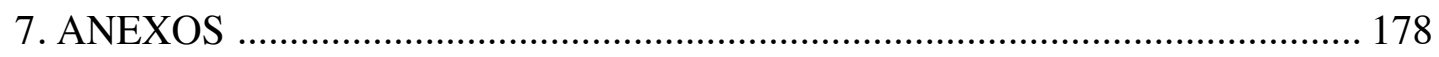




\section{O CURSO DAS ÁGUAS}

Escolher a saúde mental como campo de atuação e pesquisa não acontece por acaso. Por esse motivo, compartilharei um pouco sobre o meu trajeto universitário, período em que vivenciei um turbilhão de novos processos de identificação e novas possibilidades de escolha. Logo no início do percurso acadêmico, depararei-me com uma pergunta aparentemente simples, mas carregada de uma enorme complexidade: "quem sou eu?". Esse convite a uma revisão identitária me fez refletir e tornou mais claro alguns agenciamentos, por exemplo: como nos identificamos e somos identificados por um nome, pelo pertencimento a um território, por meio de recortes como idade, gênero, raça, classe, e ainda, como somos marcados pelos papéis sociais que desempenhamos. Para responder a essa pergunta, percebi que a reunião de todas essas características, essas pequenas partes que me integravam, não parecia ser suficiente para representar o todo. Preencher uma ficha cadastral mental não me situaria no mundo, muito menos me definiria. Fui percebendo que eu era mais que a percepção dos outros sobre mim e mais que minha própria percepção. Não era apenas performance pública, nem apenas uma manifestação intra-psíquica, não era uma única medida. Descobri, finalmente, que eu era movimento. Expandi esse raciocínio à compreensão do ser humano e percebi que a realidade e a virtualidade coexistem em todos nós, pois todos somos carregados de potência, de virtus, enquanto campo de possibilidades, como Pierre Lévy compreendeu.

A dimensão autoformativa presente nesse exercício de revisão das representações me levou a territórios existenciais marcados por um processo de constante desconstrução e politização. Para responder à pergunta "quem sou eu", outras perguntas precisavam ser feitas: com o que eu me identificava e por quê? Como estudante de psicologia, tinha a fantasia de que seria possível desvendar os significados ocultos de cada escolha individual, acreditava num certo poder de decifrar códigos mentais não-conscientes por meio de uma interpretação imparcial encontrando respostas na dissecação da dinâmica familiar. É verdade que demorei para ampliar essas explicações autocentradas e perceber que a subjetivação se constrói a partir da relação com outro, com a cultura e até com aquilo que ultrapassa o próprio entendimento. Foi aos poucos que reconheci a existência de tantas estruturas sociais invisíveis que condicionam nossos desejos, colonizam nossos afetos e que nos violentam silenciosamente todos os dias. 
Para conhecer o meu devir, parecia ser necessário descobrir todas as possibilidades de identificação que me foram negadas, os mais diversos sistemas simbólicos engolidos por um projeto civilizatório normatizador. Isso se refletiu claramente na graduação. Como qualquer estudante, o desejo de experimentar todos os campos possíveis de atuação em psicologia era um misto de entusiasmo e angústia. Era como se eu me deixasse apaixonar por todas as áreas simultaneamente, consciente da minha infidelidade. Gostava desse sentimento de exploração, de viver a dimensão multifacetada das minhas identidades e seguir diferentes caminhos: ter o privilégio de me deixar perder para depois me encontrar. Tomei gosto por trair a tradição, mesmo com algum (baixo) custo social implicado. Abandonando todos os ditames modernos, aprendi a aceitar minha própria desordem, incerteza, transitoriedade e contradição.

Foi assim que me aproximei da Psicologia Escolar, Social, Organizacional, da Saúde Mental e também da Antropologia. Dediquei-me às discussões sobre identidades sociais, preconceito, gênero, corpo e subjetivação. O fio condutor de todas essas áreas aparentemente marcadas por epistemologias tão distintas foi o descobrimento da diversidade humana em diferentes perspectivas. Uma diversidade que não habitava um mundo científico externo a mim, ao contrário, ela constituía meu corpo, meus desejos, minha subjetividade.

Inicialmente, eu alimentava certa aversão à prática clínica e usava como justificativa as supostas características individualizantes e elitistas desse tipo de setting de normatização e de adequação ao modo capitalista. Posteriormente, descobri que o incômodo poderia ter outra origem. Sabemos que o imaginário social ainda é permeado pela figura do psicólogo clínico como único representante da categoria e, por esse motivo, a presença da psicologia em outros campos (escolar, hospitalar, social, etc) parece ser ainda nebulosa. O desafio de desinstitucionalizar o próprio campo de atuação da psicologia me levou a pensar na desterritorialização como ponto de partida para uma reterritorialização.

Confesso que especialmente a Saúde Mental me capturou pela exigência de um olhar transversal a todos os campos, pelas discussões ético-políticas, históricoculturais e sociais que me mobilizaram intimamente. A integralidade de saberes, a valorização da arte e da diversidade estimularam os meus processos de identificação e trouxeram algumas respostas sobre aquele questionamento primeiro: quem eu sou. Se antes a Comunicação, a Saúde Mental e os Direitos Humanos pareciam estar em lados 
opostos, hoje percebo as infinitas conexões que precisam ser exploradas. Os interesses híbridos que, até então, provocavam certo sentimento esquizofrenizante constituem para mim a marca da singularidade.

Esse estudo é um compartilhamento de ideias, de pontos que foram conectados a partir da história de vida de alguém que teve oportunidades de escolha, que pôde celebrar a multiplicidade de identidades existentes no cenário pós-moderno. Muitos estão do lado de fora da festa, recebem uma identidade deteriorada e permanecem condenados à invisibilidade. Eu tenho o privilégio de usurfruir de alguma liberdade e, em alguma medida, ter alguma voz, mas quantos continuam tendo suas histórias apagadas, difamadas, violentadas, reduzidas a categorias abstratas, preconceituosas em nome de uma suposta ordem social de uma minoria hegemônica? As identidades desviantes correspondem à maioria quantitativa, melhor dizendo, correspondem à sua totalidade. Somos todos desviantes, pois permanecer sempre na linha é uma impossibilidade humana. A violência e a exclusão, entretanto, não atingem a todos de forma democrática, há uma injusta predileção de classe, gênero, raça, religião que são subjugadas para perpetuar uma cultura de colonialidade.

Colonialidade, modernidade e manicomialidade, compactuam a mesma lógica sob diferentes argumentos, formando o tripé da estrutura violenta da nossa sociedade. O nosso sistema de razão produziu um holocausto irreparável cujas consequências são visíveis ainda hoje pelo não-reconhecimento do outro como sujeito de direitos e pela interdição do olhar à alteridade. A invenção da psiquiatria é um exemplo disso.

Sendo assim, meu interesse nesse estudo não é explorar os subalternizados por um discurso de vitimização, nem delinear "quem são eles", como mero objeto de investigação. Prefiro romper com toda a pretensão de neutralidade e distanciamento científico, abandonar os princípios isomórficos e estabelecer uma reflexão aberta. Interessa-me saber "quem somos nós" e como podemos garantir o direito de comunicar livremente a nossa diversidade. É verdade que há sofrimento e as marcas de um corpo torturado pelas instituições de violência são irremediáveis, mas sempre é tempo de escutar o outro, sentir com o outro e agir. Os novos caminhos estão diante de nós. 


\section{CAPÍTULO I - A NAU DOS LOUCOS: UMA VIAGEM SEM VOLTA?}

A tarefa é, pois, alargar nossa razão para torná-la capaz de compreender aquilo que em nós e nos outros precede e excede a razão. (MERLEAU-PONTY)

\section{1 - O Prisioneiro da Passagem}

No início da Idade Média até o final das Cruzadas, uma onda de leprosários invade o cenário europeu. A representação dos leprosos era associada a uma manifestação de Deus, seja de sua cólera, seja de sua bondade. A doença, fundamentada num antagonismo essencial, era concebida como graça concedida pelos céus para punir os males cometidos neste mundo. Aceitando estes desígnios os leprosos receberiam a purificação espiritual. Pelas mãos dos padres e seus assistentes, os lazarentos eram arrastados para fora da Igreja, mas eram assegurados de que as portas da salvação lhe estariam abertas. Assim, a exclusão ofereceu-lhes outra forma de comunhão. O leproso torna-se, então, uma "figura insistente e temida que não se põe de lado sem se traçar à sua volta um círculo sagrado". (Foucault, 1978, p. 9)

Após o fim das Cruzadas e com a ruptura dos focos orientais de contaminação, a lepra também chega ao seu fim num estranho desaparecimento ocasionado pela própria segregação. Apesar dos leprosários vazios, continuavam vivas as inúmeras imagens atreladas ao personagem do leproso e a memória da exclusão. Eis que ao final do século $\mathrm{XV}$, as doenças venéreas surgem como a nova substituta. Por herança, são destinados aos mesmos hospitais antes ocupados pelos leprosos. Com o aumento do número de infectados, foi necessário pensar na construção de outros edifícios em certos lugares nos arredores - sem vizinhança. (Foucault, 1978)

Tal como a lepra, a doença venérea foi inicialmente considerada num conjunto de juízos morais, mas, posteriormente, a compreensão médica teve mais influência para enquadrá-la na ordem das demais doenças que exigiam tratamento. Curiosamente, no século XVII, período marcado pelo internamento, a doença venérea se aproximou da loucura pelo espaço comum da exclusão, todavia, não seria capaz de assegurar o papel cabido à lepra no mundo clássico. Por isso, os novos lazarentos apareceriam somente mais tarde, permanecendo no imaginário social um emaranhado de representações sobre a morte, a punição divina e a purificação. (Foucault, 1978). Uma nova representação do mal viria assombrar a população: envolta de uma 
obscuridade que a medicina tardaria a se apropriar, a loucura, então, seria a manifestação mais apropriada para encarnar os medos seculares herdados pela lepra.

Foi então que na paisagem imaginária da Renascença, surgia entre as ondas oníricas de heróis e viagens simbólicas, um estranho barco que navegava pelos rios da Renânia e dos canais flamengos e carregava para longe do mundo uma carga insana. Frequentemente marinheiros recebiam a tarefa de livrar a cidade de algum louco que por ali andava nu. Detidos pela autoridade, outros tantos indesejáveis também embarcavam num trajeto sem volta. Não se sabe ao certo o sentido exato sobre o nascimento desse costume, o fundo mítico dessa barca nunca esclareceu os motivos que levaram a existência errante dos loucos a uma medida de expurgo.

Por outro lado, é interessante notar que os loucos não eram corridos das cidades de modo sistemático, supõem-se que esse era o destino apenas dos estrangeiros, "aceitando cada cidade tomar conta apenas daqueles que são seus cidadãos $^{l "}$ (Foucault, 1978, p.14). E como procediam com os loucos não autóctones? A questão não era simples. Para embaralhar ainda mais, surgem os lugares de peregrinação organizados pelas cidades que, possivelmente, levavam os loucos como peregrinos para outras terras, purificando-se assim de sua presença. Ora, não era só pela utilidade social que existiam essas naus, mas havia certo ritual de purificação na exclusão.

A grande metáfora da nau era a água. Ela levaria embora, purificaria e entregaria os loucos à incerteza de um destino, em que cada navegação seria potencialmente a última. Aprisionados no interior de um barco, exterior às terras conhecidas e entregues à própria sorte, vagavam numa geografia semi-imaginária. Não havia o que se esperar do outro lado. Não havia lugar de pertencimento para o prisioneiro da passagem.

Fechado no navio, de onde não se escapa, o louco é entregue ao rio de mil braços, ao mar de mil caminhos, a essa grande incerteza exterior a tudo. É um prisioneiro no meio da mais livre, da mais aberta das estradas: solidamente acorrentado à infinita encruzilhada. É o Passageiro por excelência, isto é, o prisioneiro da passagem. E a terra à qual aportará não é conhecida, assim como não se sabe, quando desembarca, de que terra vem. Sua única verdade e

\footnotetext{
${ }^{1} \mathrm{O}$ termo "cidadão" aparece pela primeira vez na obra A História da Loucura aludindo a noção de cidadania ao pertencimento do sujeito à cidade. Interessante notar que o tom de aceitação ou tolerância em relação à presença dos loucos está ancorado à noção de território implicando em uma relação com o coletivo.
} 
sua única pátria são essa extensão estéril entre duas terras que não lhe podem pertencer. (Foucault, 1978, p.12).

O prisioneiro da passagem paira no tempo como se ninguém o houvesse parido. Sua identidade narrativa é borrada ao longo de uma viagem sem fim que culmina num esquecimento progressivo. Esse viajante não tem luxo algum, seus hábitos e seus prazes foram completamente desconsiderados e, assim também, foram suas lembranças. Seus laços já fragilizados com seus entes, com sua terra, foram desmanchados sem despedidas. Perderam-se nas águas. O que a razão não entendia, o mar engoliu.

Essa rica alegoria entre água e loucura poderia ser explorada pela leitura de tantos contos míticos que, na época, habitavam os sonhos do homem europeu. Não foi à toa que Foucault (1978) apontou a Nau dos Loucos como a figura mais simples e, no entanto, a mais simbólica. As percepções obscuras sobre a loucura e a ambiguidade de seus símbolos foram se transformando ao longo do tempo, mas certas estruturas segregatórias persistiram na história. Para continuar a demarcar o limiar com o mundo da sanidade, as embarcações nunca cessaram, mas seguiram em forma de internação. Trocamos a barca dos loucos pelo trem de doido, cujos prontuários podia-se achar registrado "tristeza" como sintoma responsável pela internação. A esses sintomas abstratos o desejo de punir lhes concedia a tortura sob pretexto de um tratamento psiquiátrico. As paredes de madeira do barco transformaram-se, então, em muros de concreto e janelas com grades.

Esse mélange de conto e realidade é o retrato mais fiel da incompreensão da loucura até a atualidade: o corpo arrastado para o enclausuramento no interior das instituições continua vagando num oceano de incertezas. Muitos profissionais da saúde, para evitar o esforço do descobrimento de novas terras e o consequente incômodo da novidade, não se aventuram a explorar outros caminhos. Contra a maré, tentamos mudar a rota da viagem para fazer com que a loucura não permaneça nesse mesmo (não) lugar. Entre avanços e retrocessos, o leme segue disputado por forças que se opõem em diversos campos, desse modo, resta-nos descobrir outras estratégias para que essa disputa - que é anterior a loucura - não nos leve a caminhar em círculos. 
1.2 - Considerações sobre o corpo enclausurado

Tal como as embarcações, os presídios, os hospitais, os exílios, os mosteiros, os conventos e outros claustros obrigavam o sujeito a se deparar com uma configuração estrangeira a ele. Sob o pretexto de retirar todas as inteferências que pudessem prejudicar o processo de inculcamento da ordem e da disciplina nas mentes desregradas, o isolamento era uma estratégia comum a essas instituições. Era assim que, conduzidos à exterioridade, tornavam-se "alguém de fora" (Amarante, 2013). Não por acaso, fora de si, fora da realidade ou fora do mundo são ideias associadas a origem etimológica do termo alienado.

Mesmo apresentando propósitos distintos, essas instituições possuem características semelhantes, como a vigilância perpétua e constante dos indivíduos e a sequência de atividades imposta por um sistema de regras formais baseado num plano racional único, supostamente planejado para atender aos objetivos oficiais da instituição. Em função do fechamento e do totalitarismo, Goffman (1974) denominou esses locais como instituições totais.

A partir de sua pesquisa etnográfica realizada no período de 1955 a 1956 no Hospital Sto Elizabeths em Washington, o autor descreve o mundo social do internado. Durante essa pesquisa, pode-se dizer que Goffman (1974) atuava num papel desconfortável de interlocutor, não era nem integrante da equipe médica, tampouco estava nominalmente internado. Assim, ele mesmo reconhecia as limitações de seu método e os riscos inerentes à interpretação parcial sobre o mundo vivido pelo interno: "Além disso, desejo advertir que minha interpretação tem, provavelmente, muita coisa de um homem de classe média; talvez eu tenha sofrido indiretamente com condições que pacientes de classe baixa suportavam com pouco sofrimento" (p. 8 grifo meu). Ainda que sua observação sobre o recorte de classe tenha se restringido a uma análise meramente metodológica sobre a sua atuação enquanto pesquisador, fica latente uma importante questão de ordem social, infelizmente ainda pouco explorada na literatura, assim como as demais marcações corporais que parecem ser desconsideradas na experiência da loucura, como gênero e raça, por exemplo. 
$\mathrm{Na}$ introdução do seu trabalho, Goffman (1974) traz uma interessante definição sobre os enclausuramentos: "são estufas para mudar pessoas; cada uma é um experimento natural sobre o que se pode fazer ao eu" (p. 22). Em geral, essa experiência era marcada por uma série de rebaixamentos, degradações, humilhações e profanações do eu que provocavam mudanças radicais na carreira moral do sujeito, alterando as crenças que eles tinham a respeito de si e dos outros.

De acordo com o autor, a primeira mutilação do eu era marcada pela própria barreira que as instituições colocam entre o mundo interno e o mundo externo; fechavam-se as portas, encerrando qualquer comunicação entre esses dois lados. Em seguida, os processos de admissão ou "as boas-vindas" anunciavam de forma clara a posição inferiorizada que deveria assumir, tanto em relação aos dirigentes, quanto em relação aos demais internos "veteranos". O novato tinha suas roupas e seus bens retirados e em troca recebia um traje padronizado. Uniformizado pela invisibilidade, seus bolsos não passavam despercebidos. Novatos e veteranos eram diariamente examinados e qualquer pedaço de papel, mola, colchão ou fragmentos de coisas que poderiam ter algum valor simbólico eram confiscados. Também fazia parte da vida do sujeito executar uma rotina completamente estranha a ele, com a qual em nada se identificava.

O interno, despido de sua aparência usual, tinha o seu eu sistematicamente mortificado. Se lá fora poderia ser marcado pela diferença, na instituição ela seria apagada, tornava-se simultaneamente igual a todos e a ninguém. A perda de seu conjunto de identidade e, consequentemente a perda de sua segurança individual, provocava uma deformação pessoal. Não é a toa que após um longo período de enclausuramento, o sujeito podia tornar-se temporariamente inapto a enfrentar algumas tarefas cotidianas como resultado de um processo de "desenculturamento" ou destreinamento (Goffman, 1974).

Nas atuais instituições psiquiátricas, por exemplo, não são raras as histórias de pessoas que, esquecidas nas instituições, também esqueceram como abraçar pela ausência do toque e da afetividade, foram emudecendo pela falta de escuta e pela indisponibilidade do outro. O retorno à convivência - especialmente no caso da Residências Terapêuticas - sempre causa um estranhamento para o sujeito, para os demais moradores da casa e para a comunidade. Poder controlar, ele mesmo, a iluminação do ambiente, redescobrir a higiene pessoal, aprender a contar o próprio 
dinheiro, dormir numa cama apenas sua, comprar roupas, reconhecer-se num retrato na parede e ser reconhecido pelos outros são situações inusitadas e embaraçosas, mas que carregam um grande potencial de resgate de alguns elementos identitários perdidos. (Arbex, 2013)

Para o corpo enrijecido e mortificado, a recuperação dos gestos mais simples e cotidianos é lenta e exige uma enorme dedicação do profissional e do paciente. Sem dúvida, a produção de um sujeito incapacitado pela tortura covarde e pela supermedicalização como parte do tratamento moral agrava o sofrimento do interno. No entanto, antes de analisar as relações de poder entre médicos e pacientes e todas as consequências do processo de institucionalização, proponho um olhar bastante específico sobre o fenômeno do enclausuramento.

Revisando a literatura sobre essas instituições, entendo que a privação de liberdade, em si - desconsiderando as outras violências que marcam a admissão do interno - já configura uma experiência intensa e desorganizadora o suficiente para produzir marcas profundas na história dos indivíduos, tanto em relação aos que sofrem a violência, tanto em relação aos que a praticam, independentemente da categoria de instituição fechada.

Não por acaso, os autores que produziram obras sensíveis sobre a temática experimentaram na carne, ainda que temporariamente, a violência e o controle de uma vida institucionalizada. Posso citar como exemplo Eugène Minkowski, oriundo de família judia, médico, cientista, militante político e pai da fenomenologia psiquiátrica. Suas principais produções - dentre elas Psychopathologie des schizoïdes et des schizophrènes (1927), Le temps vécu (1933) e o Traité de psychopathogie (1966) - são resultado de suas experiências como psiquiatra e como voluntário no exército francês, em 1915 e na Segunda Guerra Mundial. Foi no campo de concentração que vivenciou muitos fenômenos de natureza temporal:

O calendário objetivo, nas linhas de combate, era também substituído por um mais apropriado à situação. Os dias da semana perdiam seu significado objetivo e imediato para os sobreviventes. $\mathrm{O}$ número de jornadas transcorridas em relação às que faltavam para o retorno ao acampamento servia de referencial temporal. Momentos de monotonia, de tédio, de melancolia nas trincheiras eram vivenciados como um tempo imóvel, sem perspectiva, e, consequentemente, dificultavam a noção de duração, sucessão e continuidade do tempo, naturalmente presentes na organização cotidiana da vida. (Costa e Medeiros, 2009, p. 378) 
Tais vivências o instigaram a reflexões importantes sobre a desorganização no horizonte temporal na esquizofrenia. Costa e Medeiros (2009) apontam que as obras construídas por Minkowski sobre a noção do contato da realidade e a percepção do tempo também tiveram uma grande influência da filosofia de Henry Bergson (18591941). Ao contrário das correntes materialistas, evolucionistas e deterministas que predominavam na época, ele afirmava que o tempo não era um dado, mas uma abstração construída a partir da experiência. Essa distinção entre tempo vivido e tempo cronológico, a noção de consciência corporal e o presente como sensação e movimento (sensório-motor) foram conceitos que trouxeram contribuições importantes na teorização de Minkowski sobre a crítica aos manuais de psicopatologia clássica.

Outra figura que merece ser mencionada é Nise da Silveira - a arqueóloga dos mares. Nordestina, nascida em 1905, iniciou o curso de medicina na Bahia com apenas quinze anos, numa época em que a mulher não tinha lugar na sociedade, especialmente na psiquiatria. Ativista política, foi presa no governo de Getúlio Vargas e, na mesma cela de Olga Benário, sentiu o peso da tortura. Após seu encareramento, mudou o nome e permaneceu por quatro anos escondida no norte do país. Certamente o impacto dessa experiência afloresceu seu entendimento sobre a reclusão do interno, revolucionando a visão sobre "os inumeráveis estados do ser" - termo que utilizava para se referir à esquizofrênia. O produto dessa sensibilidade foi nítido em sua posição de enfretamento firme e incessante em relação aos métodos agressivos no tratamento psiquiátrico da época.

Mas, afinal, o que há em comum nessas figuras aparentemente tão distintas? Ambos tiveram as narrativas de suas histórias interrompidas por determinações políticas, estavam coagiados a viver em um outro tempo e espaço para que suas ações pudessem ser reprimidas. Provavelmente o confinamento e o perigo do não retorno desse tipo de viagem deixaram na boca um pouco do gosto amargo do que poderiam ser as embarcações dos loucos. Há quem diga, a despeito dos riscos, que toda viagem sempre traz o potencial de ampliação do campo da percepção, já que, inevitavelmente, as referências e as amarras da rotina são suspensas, tornando possível sentir e pensar de um modo diferente. É claro que a abertura de novos horizontes e a transformação de si é facilitada quando o viajante possui sua liberdade intacta para contemplar o 
estranho e explorar o novo mundo. No entanto, quando se é prisioneiro da passagem o cenário muda, as potencialidades se comprimem e não há nenhum deslumbre na poeira e na pouca luz do calabouço.

Vale lembrar que Nise da Silveira e Eugène Minkowski não eram exatamente viajantes, nem prisioneiros da passagem, eram estranhos ao seu mundo porque estavam "a frente de seu tempo". Mesmo enfrentando dificuldades pelo pensamento contra-corrente que apresentavam, eles tiveram a capacidade de converter suas experiências sensíveis e particulares advindas do enclausuramento em discursos inteligíveis. Foi por meio de suas histórias vividas de "corpo inteiro" e da produção de sentidos arranjados linguisticamente que eles desenvolveram uma proposta revolucionária para pensar o sofrimento humano em sua complexidade.

Suas construções teóricas, como toda produção intelectual, não poderiam existir de modo desincorporado ou dissociadas da experiência sensível, pois estas surgem a partir de um instrumento cognoscente, um corpo reflexionante. Em outras palavras, o corpo textual se constituiu somente a partir do corpo consciente, num encontro entre o percebido e o reflexivo, num mesmo ato (Lima, 2007). Do mesmo modo, as emoções realizam registros simbólicos afetando o corpo e a subjetividade.

A indissociabilidade entre as faculdades sensíveis e intelectuais é inerente a esse corpo que adquire consciência de si mediante a percepção do espaço e do tempo (Lima, 2007). Desse modo, a experiência do enclausuramento, caracterizado por um forçado deslocamento espacial e pela imposição de uma outra organização temporal, é incompatível com a percepção de si no mundo e poderia compor um alto potencial desorganizador. Ainda que o processo do sofrimento seja advindo de uma complexa rede de eventos anteriores, as portas fechadas das instituições totais podem representar a porta de entrada para a produção de sintomas. Não são raros os casos de pessoas em situações de privação de liberdade que, em função da perda do contato com a realidade, desenvolvem alterações da percepção, do pensamento, do raciocínio e/ou da memória, conforme a classificação psiquiátrica.

Vale lembrar que essas alterações, tais como os delírios, alucinações, comportamento bizarro e despersonalização, são fenômenos da experiência psíquica do sujeito e, quando fragmentadas em domínios como "memória", "pensamento", "afetividade" e "senso-percepção, acabam por introduzir "uma artificialidade incompatível com a complexidade do processo psíquico observado em sua 
totalidade." (Pereira, 2004, p. 127). Nessa perspectiva, a abordagem fenomenológica de Minkowski propõe a descrição da totalidade do fenômeno, ou seja, a análise de sua estrutura enquanto uma consistência fenomenológica.

É nessa perspectiva, também, que Minkowski assume resolutamente a concepção de que a psicopatologia constitui uma psicologia do patológico e não uma patologia do psicológico. Essa última proposição obriga o clínico e o pesquisador a recorrerem a uma incerta referência à noção de "normalidade", concebida como padrão absoluto a partir do qual se definem os desvios mórbidos da vida mental. (...) Com tal atitude teórica e metodológica, Minkowski aborda o fenômeno esquizofrênico visando exprimir o fundo existencial sobre o qual este transcorre, antes de realizar um recenseamento de sintomas e de alterações das faculdades da alma. (Pereira, 2004, p. 128)

Desse modo, os sintomas - fenômenos secundários - nada mais são que tentativas de compensação da desorganização psíquica, ou seja, meios que o sujeito encontra para se inscrever subjetivamente em um cenário novo, incomprensível e fragmentado que lhe imprimem sensações de medo e de angústia. Desviando-se da leitura psiquiátrica clássica, Minkowski propõe pensar a esquizofrenia enquanto ruptura radical com o mundo, em que o sujeito é levado a reconstruir, de forma forçada e artificial, uma nova percepção de seu corpo e de sua existência. É pela perda do contato vital com a realidade que o sujeito mergulha em uma vivência de absurdo e de sem-sentido (Pereira, 2004).

Em Le trouble essential de la schizophrénie et la pensée schizophrénique, Minkowski (1927/2002) nos traz uma metáfora sobre o desmoronamento de um edíficio que apresenta uma tradução muito mais próxima do processo esquizofrênico que as próprias definições atuais da psicologia:

Tentando ter uma ideia do processo esquizofrênico, nós mesmos nos deparamos, mais de uma vez, com a imagem de um edifício feito de tijolos e de cimento; os tijolos podem desmoronar, o cimento também; o edifício passa a não se sustentar mais e entra em colapso (...) as ruínas não serão mais as mesmas, nem terão o mesmo aspecto, nem o mesmo valor (...). Minkowski (1927/2002, p. 105, tradução da autora).

Segundo o autor, o uso dessas metáforas não seria um passa-tempo, mas um modo de provocar nosso espírito de precisão para reconhecer que, todo um lado de nossa vida, e não o menos importante, escapa ao pensamento discursivo. A consciência também pertence a essa ordem de fatos que não deve ser "racionalizada", mas compreendida sur le vif. O contato vital com a realidade parece estar relacionado aos fatores irracionais da vida, no entanto, não refere-se a sensação ou reação motora, 
ou a excitação ou os demais conceitos ordinários elaborados pela fisiologia e pela psicologia; afinal, os cegos, os mutilados ou paralisados podem viver em contato muito mais íntimo com o ambiente que aqueles que tem todos os seus membros preservados. O contato vital é, portanto, "um fluxo de movimento que nos rodeia de todas as partes e que constitui o meio sem o qual nós não saberíamos viver" (Minkowski, 1927/2002, p.106).

Sendo assim, a quebra do contato vital com a realidade corresponde a uma perda do dinamismo íntimo da vida e não uma dissociação cognitiva, como proposto por Bleuler. Na perda de um dos fatores essenciais da vida psíquica, o sujeito busca um rearranjo possível para rencontrar um novo equilíbrio. Ainda que esse reagrupamento revele características mórbidas, o aspecto humano é salvo. (Pereira, 2004). Na esquizofrênia o élan vital ou ímpeto vital é demasiado forte e esse processo de recriação faz com que o sujeito elabore uma obra absolutamente própria, uma estratégia para tornar sua existência mais suportável, mas que rompe radicalmente com o laço social.

Tal como Minkowski, penso que a metáfora é a palavra/imagem que consegue melhor traduzir o intraduzível, já que não se encerra nas definições. Pelo mesmo motivo, acredito que a figura da nau dos loucos tem a capacidade de evocar de maneira bastante apropriada o rompimento do sujeito com o mundo e a quebra temporal e espacial no seu modo de existir.

\subsection{1 - A espacialidade}

Sobre essa relação espaço-tempo, vale a pena mencionar brevemente algumas considerações de Merleau-Ponty (1999/2005). Para o autor, o conceito de espacialidade seria entendido não como um meio objetivo, mas como um meiohumano. Nessa perspectiva, é superado o entendimento da dimensão espacial geográfica como um mundo externo, material, único e absoluto.

Segundo abordagem fenomenológica, a paisagem não pode ser apreendida por uma atividade individual, ou seja, o mundo não é percebido de modo independente e solipsista como se sujeito se tornasse espectador de uma única realidade possível. Do mesmo modo, o pressuposto de um eu interior como substância pensante também é abandonado. A consciência não é uma propriedade subjetiva como supõe o cogito cartesiano, mas sim "um estado (de consciência) que compreende percepções 
sensoriais, intelectuais e emotivas instituídas numa relação entre o eu e o objeto" (Lima, 2007, p. 75).

A filosofia cartesiana teve um papel fundamental na construção do paradigma moderno de ciência: a certeza do cogito postulada por Descartes implica uma compreensão de corpo e pensamento como entidades independentes. A distinção entre a substância espacial e a substância pensante foi formulada no intuito de "resolver o problema do conhecimento sem, no entanto, conseguir libertar-se do modelo sujeitoobjeto que constituía o problema, propriamente dito, na fundamentação do conhecimento" (Maciel, 1997, p.19). Esse pressuposto dicotômico produziu e produz repercussões graves na divisão das ciências sociais entre a psicologia e as outras disciplinas. Além de muitas vezes essa separação produzir um estudo descontextualizado do sujeito, tornar a consciência individual objeto privilegiado da psicologia impossibilita uma análise complexa que só a transdisciplinaridade poderia oferecer (Mauss, 1924/2000; Segato, 2003).

Ao criticar o mito da subjetividade, Merleau-Ponty (1999/2005) busca estabelecer uma comunicação entre fisiologia e psicologia pelo conceito de corporeidade em que corpo e alma fazem parte de terreno comum que é a existência. Ambos são constituintes do processo de ser-no-mundo, enquanto ser-corpo. Portanto, corpo e consciência não devem ser entendidos como partes separadas, mas intregrantes de um sistema, em que essas partes estão no todo, e o todo está nas partes simultaneamente. Esse raciocínio é essencial para compreender não só a ruptura do dualismo na fenomenologia da corporeidade, mas também a indissociabilidade entre social e individual na construção subjetiva do sujeito.

É por intermédio do corpo que nos instalamos no mundo da percepção: o corpo se faz revelar a significação do mundo percebido. As significações nascem do corpo, é ele que exerce um papel de mediação entre nós e o mundo. "Ele é natureza e, ao mesmo tempo, cultura. (...) É por isso que o corpo deixa de ser visto como mero mecanismo biológico, uma mera soma de manifestações causais, para ser visto como expressão de sentidos." (Peixoto, 2014, p. 318)

Tal proprosição, aparentemente simples, está muito além de meramente admitir que o corpo é espaço ou que o corpo está situado no espaço. Dela deriva a conjectura segundo a qual a indissociabilidade entre tempo e espaço, expressos respectivamente em seus correlatos ontológicos ser e estar, 
apresentam-se como formas elementares da existência. (Lima, 2007, p. 66).

Em resumo, pode-se dizer que o sujeito de propriedades geográficas é, primeiramente, um corpo, é por intermédio dele que somos constituídos no mundo. Na obra Fenomenologia da Percepção de Merleau-Ponty (1999/2005), o uso do termo motricidade nos indica que o corpo não se move pelo fato de existir espaço, como uma máquina que se movimenta por si; mas porque pertence a um meio-humano que o corpo responde com movimento e, assim, produz-se espaço, entendido dessa forma como um campo de possibilidades, como horizonte de significações.

No corpo habita a virtualidade, ou seja, há um conjunto de possibilidades que se abrem a um campo de experiências que propriciam o surgimento de novos sentidos. Pode-se dizer inclusive que "o próprio ato perceptivo já envolve um processo de significação." (Vieira \& Furlan, 2011, p. 132). O ordenamento de nossas percepções estabelece uma relação mútua entre corpo e espaço: enquanto a carne reúne as dimensões objetivas e fenomênicas do corpo numa mesma superfície de contato, o espaço é concebido como experiência do corpo e superfície da existência (Lima, 2007).

Assim, meu interesse em expor essas considerações sobre corpo-espaço não é de simplesmente propor uma transposição teórica acerca da superação do dualismo, mas de ressaltar o movimento e a multiplicidade de sentidos que um sentido pode ter. No entanto, apesar da constatação da existência de infinitas singularidades inerentes aos corpos e aos modos de existir no mundo sabemos que muitos escapam ao reconhecimento de uma manifestação humana legítima. Assim, como profetiza a psiquiatria: aqueles que não passarem pela porta estreita da norma estarão fatalmente condenados ao enclausuramento.

Relembrando a nau dos loucos e percebendo o funcionamento dos manicômios, observo duas tendências para um mesmo fim: a primeira trata-se do enclausuramento daqueles que, segundo Minkowski (1927/2002), já haviam perdido o contato vital com a realidade, antes mesmo de serem submetidos aos processos degradantes da institucionalização; a segunda tendência trata-se dos demais enclausurados, os não-loucos também recolhidos em obediência à ditadura da ordem social, que, ao experimentarem a vida institucionalizada, poderiam perder o contato 
vital com a realidade num movimento de sobrevivência à violência.

Vejo que as velhas e novas embarcações, atendendo aos apelos de uma suposta normalidade ofendida, continua a reafirmar sua decisão secular de apartar toda a diversidade do mundo. Num movimento de desintegração, abrimos mão de quem somos negando nossas partes. Esse ato esquizofrênico de fragmentação da sociedade produzido pelo excesso de institucionalização da vida nos conduz a uma perda do nosso contato vital. A própria invenção do enclausuramento é um sintoma desse rompimento.

Tecendo essa breve análise sobre o corpo como próprio sujeito da cultura, fica um questionamento: qual o destino da nossa cultura quando, em nome da ordem e da razão, continuamos a sacrificar tantos corpos em enclausuramentos? É verdade que a própria pergunta parece nos conduzir a uma resposta fatalista, no entanto, a postura mais adequada, ao meu ver, transcende qualquer visão pessimista ou otimista em relação às embarcações continuadas. A resposta está além desses dois pólos, ela se desloca a uma instância mais distante e convoca uma outra categoria temporal: a esperança.

A esperança se projeta na direção futuro-presente e alarga a perspectiva do futuro oferencendo-nos um horizonte de possibilidades (Costa \& Medeiros, 2009). Mas cuidado, esperança não é espera, não podemos nos limitar apenas à sua dimensão contemplativa, correndo o risco de se paralizar diante de seus horizontes infinitos. $\mathrm{O}$ alívio que a esperança nos oferece durante a espera pode se tornar mais fascinante do que a própria realização, já que esta encerra as possibilidades. O que deve ser destacado é que a esperança também é um elemento constitutivo e construtivo do advir, cabe a nós associar o sentir com o agir.

Para agir é preciso se deixar ser tocado pela história. O exercício filosófico em problematizar a corporeidade e o enclausuramento é mais que o reconhecimento do holocausto enquanto evento histórico, é na verdade, o reconhecimento de cada corpo privado, diagnosticado, torturado e oprimido. Quando imagino nos sessenta mil mortos vítimas do maior hospital psiquiátrico do Brasil, penso na morte de uma única pessoa, um evento lamentável e que se repetiu sessenta mil vezes. Assim, o primeiro passo para orientação da nossa ação no mundo é: 
descobrir o ser-aí por detrás do sintoma, uma vez que carne, sangue e nervos são apenas uma fina camada que envolve um segredo invisível, uma estória que mora em nós. O paciente não é um caso, e sim uma pessoa, cuja linguagem da alma se expressa no corpo, no tempo do relógio e no tempo vivido. (Costa \& Medeiros, 2009, p. 383)

1.2.2 - A temporalidade

A base natural do tempo, o dado sensível do correr do tempo, torna-se humana e social ao existir para o homem. (DEBORD)

Afinal o que é o tempo? Desde a antiguidade analisamos o tempo racionalmente, verificamos as repetições dos intervalos regulares no espaço, identificamos dia e noite, estações, meses, semanas, dando-lhes marcações númericas. Mas diante de toda essa organização objetiva, o transcorrer do tempo sempre me pareceu algo mais que o girar de um relógio, especialmente quando a morte mostra a sua face mais de perto. O fascínio em compreender algo de natureza quase incompreensível não é novidade no campo da filosofia. O desejo em saber sobre o tempo vêm desde os pensadores pré-socráticos e até hoje o tema não conseguiu ser completamente exaurido pelo conhecimento. Evidentemente não será possível percorrer aqui todas as proprosições filosóficas sobre o assunto (nem é este o propósito) por isso, farei um breve levantamento da compreensão de tempo segundo a abordagem fenomenológica minkowskiana.

O tempo refere-se a uma experiência primária e vital, uma consciência que dura em uma sucessão de momentos, uma continuidade vivida, um movimento. A isso, Minkowski chamou devenir. O tempo encontra-se na existência de duas formas: como "tempo assimilado ao espaço" ou a medida mensurável pela organização cronológica da vida; e como "tempo qualidade ou tempo vivido", o tempo da experiência, da instrospecção, tal como aparece à consciência. O entendimento de que o tempo não se reduz apenas às dimensões espaciais mensuráveis é o primeiro passo para considerar que a organização temporal não é homogênea, nem nos é dada naturalmente. Além disso, "pode-se vivenciar o tempo com "velocidades", intensidades e "extensibilidades" que se diferenciam em virtude das situações e sentimentos que delas decorrem." (Costa e Medeiros, 2009, p.378)

Na filosofia merleau-pontyana, influenciada pelo pensamento de Minkowski, o conceito de temporalidade também perde o seu caráter objetivo, pois é interpretado 
como construção humana, como horizonte existencial. O tempo depende de um desenvolvimento histórico autoconsciente, portanto as três dimensões temporais apresentam sentido quando o homem se projeta: no passado, a história do indivíduo sujeita a ressignificações; no presente, a experiência imediata, o tempo de ação; no futuro, as possibilidades vindouras. Dessa maneira, essas dimensões são experenciadas simultaneamente, atuando nesse ser-projeto (Maciel, 1997). Assim, tal relação retrospectiva e prospectiva não é mecanicamente medida do tempo, mas vivida existencialmente pela subjetividade do sujeito.

Percebe-se então que as experiências em si não são determinantes na história do indivíduo, pois a representação desses eventos se modifica de acordo com cada significado que lhe é atribuído. Através do olhar fenomenológico o presente, por exemplo, é concebido como um ato de muita complexidade que une o passado e o futuro, caracteriza-se pela duração, sucessão e continuidade ao tempo vivido. Poderia eu lembrar-me do passado e senti-lo mais vivo que o próprio presente ${ }^{2}$, e simultaneamente, projetar-me a uma perspectiva futura mais ampla. "A existência do presente como fruto de um passado do qual surge e de um futuro para o qual se dirige por intermédio de seus elementos estruturais e do fenômeno 'élan vital', que cria o futuro diante de nós." (Costa \& Medeiros, 2009, p. 382).

Significa dizer que o tempo é mais que uma dimensão do mundo, é a orientação significativa do ser, não determinada pelo passado, mas pelo horizonte existencial. Acredito que esse pressuposto já nos indica mais concretamente como a obra de Minkowski foi inovadora ao analisar a psicologia do patológico, e não o seu inverso. Sem dúvida, sua percepção da temporalidade trouxe contribuições importantes sobre as alterações da personalidade e a desestruturação implicadas na perda da duração do tempo vivido. Além disso, sua sensível perspectiva psicopatológica que valorizava o contato pessoal, também enriqueceu as discussões acerca do encontro clínico.

\footnotetext{
${ }^{2}$ Existe uma diferença entre o agora e o presente: "O presente tem a função de permitir que o agora se instale. O agora é pontual, é um instante, uma parte elementar do tempo, no qual não se observam os fenômenos da duração e da sucessão. (...) $\mathrm{O}$ agora é a consciência da existência no presente. Ele é um ponto muito denso, no qual se concentra, em um instante, o último momento do passado e o primeiro momento do futuro. Ele está no presente, anima-o e o torna vivo, mas não é o presente." (Costa \& Medeiros, 2009, p. 379)
} 
Ao apresentar perspectivas fenomenológicas em atendimentos clínicos, Antúnez (2012) faz um levantamento biográfico sobre Minkowski e suas obras. Um relato bastante interesse sobre a relação terapêutica entre Minkowski e um paciente me chamou a atenção. Na convivência durante dois meses, dia e noite, com um senhor de sessenta e seis anos diagnosticado com esquizofrenia e melancolia, surgem as impossibilidades de assumir a postura de médico em tempo integral. Através dessa relação, posteriormente descrita em Traité de psychopathogie (1966), o autor constatou melodias radicalmente desarmônicas.

Ele detecta naquele paciente com esquizofrenia melancólica o desacordo de duas melodias humanas - a do terapeuta e a do paciente - que se confrontam a maior parte do tempo e apresentam a estrutura do tempo vivido em cada um deles. No paciente, o tempo se fragmenta e ele perde a ressonância no contato com o outro, sua vida perde o colorido. O devir do paciente está barrado por suas ideias delirantes. O passado o imobiliza pelas ideias de culpa, o tempo presente aparece sob a forma de ideias indignas de ruína. Em nós, terapeutas, o devir está em aberto. Para ele (Minkowski) o paciente ou o outro é compreendido como um ser diferente e semelhante e não um doente (Antúnez, 2012, p. 42).

Essa postura de reconhecimento da alteridade é fundamental para que o profissional de saúde conheça as diferentes temporalidades possíveis, bem como suas diferentes velocidades. Se debruçar sobre o tempo vivido do outro, identificando as projeções futuras, as rupturas nas narrativas, a perda do efeito de duração e de continuidade são elementos que podem ter um importante valor clínico. O profissional da saúde compreendendo como o passado se faz presente na vida do sujeito poderia colaborar para o resgate do seu protagonismo sobre a própria vida na medida em que seus projetos existenciais fossem ressignificados e ampliados. (Costa \& Medeiros, 2009).

Penso que a legitimação de uma outra organização de temporalidade representa a própria legitimação do outro. O mesmo raciocínio vale para a análise do fenômeno da alucinação e do delírio que também devem ser entendidos enquanto manifestação radical da alteridade e expressão existencial. Como se sabe, a alucinação é uma experiência não compartilhada, não representável ou assimilável racionalmente. Em seus estudos sobre o conceito de alucinação em Merleau-Ponty, Campo e Coelho Jr. (2002) apontam que alucinar não se configura um fenômeno puramente simbólico, mas uma expressividade do corpo próprio. 
Todavia, nas aulas de psicopatologia ainda é forte a tendência à uma epistemologia objetivista em que a alucinação é determinada por um critério empírico. Defini-la como "uma percepção sem objeto" certamente atende aos interesses de previsão e controle da psicologia acadêmica clássica e da psiquiatria. É a esse referencial reduzido e desprendido de interesse compreensivo do fenômeno que Merleau-Ponty se opõe radicalmente. O sujeito que alucina tem noção da irrealidade de sua alucinação, diferenciando-a da percepção normal pela sua solidez e pelo seu sentido, ela não é percebida tão nítida quanto a realidade, mas é sentida como uma distorção na configuração existencial.

Essa diferenciação não torna a alucinação menos legítima, mas indica que os critérios objetivos não capazes para analisá-la de forma complexa, já que ela poderá ser explicada apenas em seu sentido existencial. Diante dessas impossibilidades, o mais aconselhável é substituir a busca por uma causa ou uma razão e o uso de constructos empíricos e idealistas, por uma outra categoria de entendimento que Merleau-Ponty denominou motivo. Essa alternativa compreensiva diz respeito a uma análise do sentido, considerando suas múltiplas significações. (Campos \& Coelho Jr., 2002).

Vale relembrar que a teorização metapsicológica de Freud, desde os estudos sobre a histeria no início da psicanálise, também inaugurou um campo de conceituações interessantes acerca da questão da alucinação. Se antes a percepção sem objeto era apontada como uma falha, com a visão interpretativista da psicanálise esses fenômenos passaram a ser investigados a partir da compreensão das pulsões e da vida simbólica do sujeito desejante. Sem dúvida, a importância dada a análise dos sentidos representou um grande ganho epistemológico, entretanto, a afirmação de um um modelo dinâmico universal de um desenvolvimento psicossexual ainda me parece bastante arriscada (Campos \& Coelho Jr., 2002). Por isso, para ir além de um enfoque intra-psíquico, a visão fenomenológica parece ser a mais adequada para lidar com fenômenos que se constituem a partir da corporeidade:

Sob a ótica da fenomenologia de Merleau-Ponty e longe dos determinantes objetivos que os definem classicamente, alucinação e delírio devem ser entendidos na ambigüidade intrínseca ao corpo e à temporalidade. São manifestações da estrutura primordial da existência enquanto intencionalidade enrijecida. Cortando os fios intencionais com o mundo e com a experiência 
intersubjetiva, o sujeito perde toda a significação em seu gestos. Isso é verdade também para a fala: o sujeito transborda todo o seu ser na atmosfera mórbida e faz da relação intersubjetiva uma relação de si para si, projetando em um outro imaginário sua própria potência comunicativa abstraída e desubstancializada. Despersonalizando-se, o sujeito alucina e a alucinação é resultado da estrutura mórbida da existência. A compreensão da alucinação, portanto, estende-se a um campo fundante da experiência. Dessa forma, a estrutura e o sentido da alucinação remetem, invariavelmente, à temporalidade, à espacialidade, à potência intencional, ao corpo e ao outro. (Campos \& Coelho Jr., 2002, p. 29)

Esses sintomas, entretanto, não representam uma destruição irreparável das faculdades psíquicas do sujeito. A noção de perda de contato de realidade traz consigo a possibilidade de restabelecer esse contato, seja inteiramente ou, ao menos, parcialmente. Assim, retomamos a pergunta lançada no título desse capítulo: seria a nau dos loucos uma viagem sem volta? Por mais longe que os tenhamos arrastados pelos mares, milhas e milhas até perdê-los de vista, não há um só prisioneiro da passagem que tenha perdido seu potencial para o retorno. Contudo, mais importante que atestar a possibilidade de reestabelecimento desse contato, é indicar de que maneira poderemos contribuir efetivamente para esse processo, afinal, o profissional da saúde também faz parte do mundo de seu paciente (Minkowski, 1927/2002).

No final de sua obra La schizophrénie, Minkowski(1927/2002) ao constatar a falta de contato afetivo com o esquizofrênico, nos interpela: não seria oportuno tentar estabelecer esse contato? ${ }^{3}$ Todo psiquiatra é uma presença que anuncia algo. Em alguma altura de sua carreira, a partir do momento em que ele considera seu paciente como incurável ou após tentativas frustradas, ele abandona a partida e torna-se outro. "Uma das cordas que se estende de homem a outro homem deixa de vibrar nele, deixando-o morrer num tom lastimoso" (p. 270, tradução da autora). É assim que, diante dele, não há nada mais que um alienado que se afunda cada vez mais em seu autismo.

A noção de esquizofrênia abre um campo mais vasto que as discussões mesmas acerca dos sintomas do paciente, ela nos indaga sobre nossa conduta vis-àvis, sobre a necessidade de uma postura ética ao endereçarmos ao paciente. Acredito que a reversibilidade se estabelece na própria intercorporeidade: ela se inicia no reconhecimento do outro como sujeito de potencialidades e, sem nos darmos

\footnotetext{
3 "Nous constatons que nous n'avons pas de contact affectif avec le schizophrène. N'est-ce pas dire que nous devrions essayer de l'établir?" (p. 270)
} 
claramente conta, nossa atitude acaba por produzir alguma influência sobre sua individualidade, sobre sua família, sobre o seu contexto e, assim, tende a diminuir essa força hostil que é a realidade para o paciente. (Minkowski, 1927/2002).

O convite à retomada do contato afetivo certamente altera a qualidade da relação médico-paciente e traz avanços visíveis no campo da saúde mental. Entretanto, me atrevo a uma postura mais radical: não há como se falar em processo de saúde se não há construção de vínculo entre essas partes. Por isso, parto do pressuposto que o único caminho para dar um outro lugar para "desrazão" é combater o próprio sistema da razão resgatando o que nele foi expurgado: o pathos. Para se trabalhar com os afetos é preciso desenrijecer as relações e, na medida adequada, se deixar afetar. 


\section{CAPÍTULO II - DIVISÃO DE MARES: O MUNDO DA RAZÃO/DESRAZÃO}

Les lois, la coutume vous concèdent le droit de mesurer l'esprit. Cette juridiction souveraine, redoutable, c'est avec votre entendement que vous l'exercez. laissez-nous rire. la crédulité des peuples civilisés, des savants, des gouvernements pare la psychiatrie d'on ne sait quelles lumières surnaturelles.Nous n'admettons pas qu'on entrave le libre développement d'un délire, aussi légitime, aussi logique que toute autre succession d'idées ou d'actes humains. (...) Les fous sont les victimes individuelles par excellence de la dictature sociale; au nom de cette individualité qui est le propre de l'homme, nous réclamons qu'on libère ces forçats de la sensibilité puisque aussi bien il n'est pas au pouvoir des lois d'enfermer tous les hommes qui pensent et agissent. (ARTAUD)

\section{1 - Pathos: os efeitos dos afetos negados}

Não se pode atravessar a vida sem sofrer, todos nós sofremos, faz parte da existência humana. O sofrimento não é um bem, nem um mal; em si mesmo, ele não tem nenhum sentido, "mas por meio dele coloca-se o problema do sentido da vida" (Minkowski, 2000, p. 157). Sofrimento, afecção, sentimento são tendências de uma certa duração da vida psíquica, afetiva, intelectual, imagética, relacionadas ao conceito originário de pathos. Apesar desse conceito ser comumente associado apenas à noção de doença, sua compreensão envolve possibilidades e problemas mais amplos (Martins, 1994). "O sofrimento, portanto, é um dos fenômenos polissêmicos por natureza, é uma experiência única, própria, intransferível, difícil, ela mobiliza profundamente, requer superação, aponta crescimentos, riscos ou oportunidades". (Costa, 2014, p. 24)

Assim, Martins (2004), propõe uma reabertura phática explorando os significados da origem desse conceito ${ }^{4}$, desde o espanto que impulsiona o filosofar até o efeito de exageração das paixões e suas passagens. Sua análise busca retomar dimensões do termo que foram pouco a pouco esquecidas. Talvez a mais intrigante das descobertas desse percurso tenha sido o reconhecimento do pathos na base da filosofia grega, a mesma que influenciou toda a construção de ciência e de mundo moderno. Se pathos e logos partem de um mesmo horizonte, "com efeito, logos e pathos não existiriam um sem o outro mesmo que nos deixemos ofuscar pela

\footnotetext{
4 "É interessante que a palavra empatia, que vem da palavra alemã Einfühlung (que Husserl usava) é composta por três partes. O núcleo fühl significa 'sentir'. A palavra grega pathos poderia corresponder a fühl, e significa 'sofrer' e 'estar perto'. " (Antúnez, 2012, p. 18)
} 
fascinação de objetos independentizados do sujeito" (Martins, 1994, p. 77).

Na análise de Foucault (1978), esse aparente antagonismo das categorias logos/pathos ou razão/loucura, também evidencia uma complementaridade referencial:

A loucura torna-se uma forma relativa à razão ou, melhor, loucura e razão entram numa relação eternamente reversível que faz com que toda loucura tenha sua razão que a julga e controla, e toda razão sua loucura na qual ela encontra sua verdade irrisória. Cada uma é a medida da outra, e nesse movimento de referência recíproca elas se recusam, mas uma fundamenta a outra. (Foucault, 1978, p. 35)

As formas de razão e formas da loucura se confundem revelando a fragilidade de seu limiar: como distinguir, numa ação prudente, se ela foi cometida por um louco, e como distinguir, na mais insensata das loucuras, se ela pertence a um homem normalmente prudente e comedido? (Foucault, 1978, p. 40). Significa dizer que os limites do patho-lógico estão muito além da definição de moderna de patológico na medicina atual, ela transcende as regionalizações dos saberes. Contudo, diante da complexidade inerente ao humano e ao pathos, por que insistimos em decompor suas categorias e privilegiar uma determinada dimensão em detrimento de outras?

Como Morin (1999) apontou, essa necessidade de isolar as dificuldades umas das outras para resolvê-las corresponderia a um dos pilares da segurança da ciência moderna denominado princípio da separação. Descartes foi, portanto, o fundador dessa noção de progresso do conhecimento que está intimamente ligada ao segundo pilar do saber cientifico: a idéia de um universo ordenado. Para tanto, a razão entraria como elemento indispensável para determinar uma coerência obediente aos princípios clássicos (da contradição, da identidade, do terceiro excluído) formando-se assim, o tripé da ciência. "O controle epistemológico, baseado na lógica, confirma a ciência clássica na sua própria verdade (...) Tudo que se desemboca em uma contradição é sinal de erro" (Morin, 2001, p. 277).

O problema se instala quando as unidades de análise tornam-se cada vez mais atomizadas e isoladas produzindo reduções graves tanto em relação aos fenômenos estudados, quanto em relação à realidade artificial que se fabrica em torno desses fenômenos. Essa realidade controlada laboratorialmente, fixa, a-histórica e ordenada 
por leis invisíveis e universais é o grande pilar do paradigma moderno ocidental. A construção de um inatacável sistema isomórfico passou ou a ignorar as emoções no campo científico ou a reduzi-las a processos fisiológicos ou a construções da linguagem. É assim que o conhecimento científico, numa pretensão objetivista, afastou-se de toda influência subjetiva a fim de extinguir todas as possíveis fontes de erro que pudessem invalidar seus procedimentos (Neubern, 2001; González Rey, 2005)

Desse modo, a dicotomia razão/emoção se fez presente no campo científico: se de um lado está a objetividade do conhecimento "superior", a estatística e a linguagem técnica; do outro lado está a subjetividade do sujeito e das relações humanas, a espiritualidade, a linguagem poética e outras formas de expressão. Situadas entre esses dois paradigmas, as ciências humanas e a própria psicologia enfrentam, desde então, grandes dilemas nesse campo pois embora almejem a legitimidade científica, também carregam o potencial para subvertê-la. (Neubern, 2001)

A questão fundamental é que, diante da necessidade de emancipação do modelo positivista dominante podemos ser conduzidos a uma cegueira epistemológica: do alto da técnica e da suposta neutralidade científica não se pode ver o imenso universo intersubjetivo que constitui toda a produção do conhecimento. González Rey (2005) aponta que o modelo quantitativo, empírico e descritivo que se baseia em evidências observáveis e estatísticas levou as ciências sociais a um metodologismo perigoso, em que instrumentos e técnicas tornaram-se os únicos critérios de legitimação da informação, excluindo a construção teórica e a reflexão do pesquisador. Dessa forma, a objetividade representada como uma pequena ponta de um iceberg torna-se uma imagem interessante para problematizar o aparente antagonismo entre objetividade e subjetividade (Neubern, 2001).

Tal como na discussão razão/loucura, objetividade e subjetividade se interpenetram, se constituem e se acusam. Ainda que analisemos o iceberg como um todo, parece que ainda esbarramos em algumas dificuldades: de seu topo a imagem que se tem do fundo é desfocada, nebulosa, uma infinidade escura diante do desconhecido; do mesmo modo, se estamos submersos e olhamos para a ponta, a imagem da superfície é distorcida e a sua claridade é incômoda à vista. Ao descrever 
qualquer uma dessas visões, automaticamente minha posição é revelada e com ela as limitações da perspectiva descrita. Ao ampliarmos o olhar e considerarmos o líquido que rodeia esse iceberg podemos supor a origem dessa visão. Aos mais desavisados, a água que separa o mundo subaquático do mundo terrestre parece fazer uma marcação rígida, uma crença que decepa essa enorme pedra de gelo em dois. Mas afinal, trata-se de uma diferença substancial ou estaríamos lidando com um mesmo elemento? As ideologias (água líquida), a objetividade (ponta do iceberg), a subjetividade (a base do iceberg) dizem respeito à vida. Outra vez a água, em seus múltiplos estados, parece nos ensinar sobre o nosso movimento e sobre as nossas limitações diante da complexidade dos fenômenos humanos.

Nesse caso, antes de afirmar que a ideologia, representada pela água líquida, corresponde a uma ilusão da realidade, é preciso lembrar que essa realidade ideológica, "é uma realidade social cuja própria existência implica o nãoconhecimento de sua essência por parte de seus participantes, ou seja, a efetividade social cuja própria reprodução implica que os indivíduos 'não sabem o que fazem'." (Zizek, 2010, p. 51). Tomando como base essa definição de "ideológica", Zizek (2010) faz um provocação: "Segundo Lacan, não foi ninguém senão Karl Marx quem inventou a noção de sintoma" (p. 42). Ora, o sintoma pode ser definido como uma formação cuja própria consistência impede que o sujeito a reconheça, ou em outras palavras, "o gozo do sintoma" é mantido pelo sujeito enquanto sua lógica não é revelada ou dissolvida pelo "sucesso da interpretação". A identificação de um desequilíbrio "patológico" na medida em que todo o universalismo dos "direitos e deveres burgueses" expõe sua falsidade. (Zizek, 2010). O problema é que, ainda que não saibamos o que fazemos, o fazemos.

Sobre essa metáfora do iceberg, percebe-se que o suposto distanciamento da subjetividade, tal como as emoções, provocam questões conflituosas:

"até que ponto é possível afirmar que a psicologia, na maioria das vezes imbuída de um forte teor de inspiração do paradigma científico ocidental realmente efetivou estudos e teorizações condizentes com a complexidade da subjetividade humana"? (...) "até que ponto a psicologia pôde desenvolver estudos e teorizações condizentes com a complexidade dos processos emocionais"? (Neubern, 2001, p. 154) 
O conhecimento não deve ser concebido como uma revelação da realidade, mas como uma construção de espaços de inteligibilidade sobre sistemas. A Teoria da Subjetividade desenvolvida por González Rey (2003) é, portanto, uma ferramenta auxiliadora para compreender o valor dos processos subjetivos na produção das experiências humanas, levando em consideração as emoções e os processos simbólicos como parte de um mesmo sistema. Trata-se de resgatar a subjetividade, não como oposição à objetividade ou como um elemento intrapsíquico, mas numa perspectiva dialética. Esse entendimento está assentado numa compreensão de um sujeito que possui desejos, sonhos e fantasias, mas que está permanentemente comprometido com suas práticas sociais e com seu posicionamento no mundo. Conceber a subjetividade como o sistema de significações e sentidos subjetivos que organiza tanto a vida psíquica o sujeito como a vida em sociedade, é entender o humano para além dos contornos atribuídos ao campo exclusivo da psique.

Vemos então que as questões levantadas pelo debate do pathos-lógico passam impreterivelmente pela a superação de diversas dicotomias: mente/corpo, subjetividade/objetividade, passional/racional, individual/social, interior/exterior, privado/público, sujeito/objeto, emoção/razão. Como vimos, a definição de pathos não comporta um fechamento em si mesma, ao contrário, pode-se dizer que a estrutura patológica se confunde com a própria subjetivação, sendo a possibilidade do sujeito em um dado tempo. Do mesmo modo que o sujeito encontra-se em constante movimento, todo o conhecimento que produzimos também é filho de seu tempo e está permanentemente sujeito a revisões, criticas e reformulações. Por esse motivo, os limites da ciência, especialmente a psicopatológica, consistem em nunca reduzir o humano a considerações puramente classificatórias e descritivas.

Entretanto, em consequência da pulverização do pathos na constituição de objetos de investigação científica, principalmente nas ciências empíricas modernas, a verdadeira questão do Ser foi se perdendo. Em vista disso, Martins (1994) marca a noção de pathos como uma disposição originária do sujeito, de caráter fundamentalmente humano. Essa dis-posição (posição na existência) diz respeito ao modo que o sujeito lidará com a realidade, ou seja, trata-se de uma disposição afetiva, subjetiva e individual que constitui seu modo particular de estar no mundo.

A valorização do aspecto pático (e não patológico) da existência também é marcante nos estudos de Minkowski. Sua atitude teórica e metodológica ao abordar o 
fenômeno esquizofrênico demonstra maior preocupação em conhecer seu fundo existencial do que enquadrá-lo em um catálogo de sintomas psiquiátricos clássicos (Pereira, 2004). De todo modo, vale lembrar que seus estudos sobre a psicologia do patológico deu ênfase à esquizofrenia pois, em função da extensão, tornou-se sinônimo da loucura; com a diferença que "louco" quer dizer "louco" e nada mais, ao passo que "esquizofrênico" remete a uma suscetibilidade de estar comprometido e de ser guiado. Certamente, como Minkowski (1927/2002) apontava, não havia nada de supérfluo na discussão sobre esses conceitos.

Mas até que ponto a criação de diferentes conceitos contribuíram efetivamente para a compreensão sobre tais fenômenos? Loucura, psicose, esquizofrenia parecem esbarrar sempre nos limites da nossa linguagem que, intencionalmente ou não, restringem as potencialidades de pathos. $\mathrm{Na}$ busca por uma unidade complexa de pensamento que não escorregue nas mesmas imprecisões conceituais, Costa (2003, 2010) adotou o termo sofrimento psíquico grave para se reportar a toda manifestação aguda de sofrimento. Diante das múltiplas possibilidades de estruturação das "psicoses" e todos os seus espectros diversos e imprecisos, a valorização da dimensão existencial dessas manifestações novamente se mostra como sendo o melhor caminho: conceber o sofrimento como parte do processo relacional, afetivo, histórico e social.

Sem dúvida, os conceitos tem uma enorme importância, afinal estes se constituem como uma mediação entre o nós e o mundo, no entanto, conceituar sobre o fenômeno dos afetos insuportáveis não é uma tarefa fácil. Não se pode medir em uma fita métrica o sofrimento, não se pode testá-lo laboratorialmente, nem admitir a mesma prescrição aos casos aparentemente semelhantes. A medida do sofrimento é sempre o próprio sujeito. Por esse motivo, os conceitos tornam-se indicadores de facetas, são recursos para entender como se organizam esses sistemas complexos, levando em consideração os limites da própria sistematização.

É preciso partir do entendimento que os sistemas de inteligibilidade que criamos através desses conceitos não são caminhos de chegadas, eles antes se intercruzam a todo o tempo com o senso comum e se refazem na presença do outro. $\mathrm{O}$ saber científico e o saber popular se constituem em circularidade, apropriando-se de ambos os pólos. "As representações sobre o corpo, saúde e doença populares influenciam diretamente na maneira como essa medicina lidará com os seus pacientes tanto na busca do diagnóstico como da terapêutica." (Ferreira, 1995, p. 103) 
Quando escuto falas como: "Olha, li numa revista uma reportagem sobre psicopatas. Eu estou com medo de ser psicopata, será que eu sou?", "eu tenho problemas em saúde mental" ou "meu psicótico está abalado", coloco em questão todos os nossos esforços conceituais. Será que atribuir novos nomes provocará mudanças concretas na vida cotidiana das pessoas? Ou devemos nos questionar ainda: quem somos nós para defini-los? Quanta violência foi usada para construir esse lugar de suposto saber? É preciso considerar que, por trás de cada uma dessas palavras, existe um longo percurso de disputas sociais, históricas e políticas, no entanto, a conclusão que chego é que essas diferentes nomenclaturas "louco", "doente mental", "usuário de saúde mental" parecem carregar pesos diferentes - ao menos academicamente - mas não tem o poder de livrar o estigma, essa identidade deteriorada tão minuciosamente arquitetada desde os tempos dos leprosários. Em outras palavras, "não se problematiza a diferença entre o conceito de 'paciente' e 'usuário', como se à afirmação semântica diversa correspondesse, automaticamente, uma abordagem de respeito e inclusão." (Oliveira \& Alessi, 2005, p. 201)

Ainda que consideremos a indissociabilidade entre a subjetividade e a objetividade e o trânsito de mão dupla entre a linguagem do médico e do paciente, no fim das contas, a quem serve toda essa produção científica? Há sempre uma violência epistêmica velada que busca neutralizar a fala do outro, expropriá-lo de qualquer possibilidade de representação. (Spivak, 2010) Ou seja, ainda que o sofrimento possa ser vivido por todos, existem certas particularidades que não podem ser mais ignoradas. Manicômio não tortura patrão, não prende branco, não mata burguês. Há um discurso colonializado que impõe a divisão entre o mundo da razão e o da desrazão, no entanto, essas categorias abstratas entre loucos e sãos é apenas a ponta do iceberg, é apenas mais uma entre tantas outras justificativas que são utilizadas para legitimar as desigualdades sociais.

Não tenho a pretensão em simplificar o debate da loucura a uma disputa de classes, mas já passa do tempo de olhar com mais profundidade para essas questões. Nesse sentido, o hiperfilosofar teórico-crítico sobre os conceitos essencialistas acerca da loucura não faz sentido algum se não estiver comprometido efetivamente com a realidade e com sua transformação. É preciso ser vigilante para não compactuar com 
uma reinserção dissimulada, para não encenar um protagonismo do Outro em que somente nós falamos por eles.

Estamos oficializando a visão de mundo dominante, mantenedora da ordem social injusta, ou estamos construindo um projeto civilizatório democrático? Acredito que o resgate da dimensão páthica pode ser um exercício para orientar nossas ações, um dispositivo ético obrigatório no campo da Saúde, no Direito, na Educação, na Comunicação, e demais saberes. A psicologia do pathos humano nos faz lembrar aqueles que foram intencionalmente esquecidos, ela retoma seus direitos, afirma sua autonomia e comunica a diversidade.

Partindo do pressuposto que o aspecto pático da existência faz parte da condição humana (Minkowski, 2000), por que alguns não são considerados "menos humanos" sob uma mesma condição? A resposta a essa pergunta não é simples, mas de alguma forma já sabemos como funciona, afinal, "a defesa da tese da inferioridade congênita ou adquirida, irreversível ou não, dos integrantes das classes subalternas é antiga e persistente na história do pensamento humano" (Patto, 2000, p. 77) ${ }^{5}$. A divisão de mares é, portanto, muito mais que a separação do mundo da razão e da desrazão, ela também se faz presente em nosso processo educacional e na nossa construção da cidadania.

Entretanto, esse corte não deve ser encarado de forma simplista, como uma formação binária de grupos radicalmente distintos: os que tem poder e os que não tem poder. Ao contrário, o poder está em todos os lados, não pertence a algo ou a alguém, ele não está localizado na figura do rei ou em um ponto fixo e permanente, mas se estabelece nas relações e se infiltra nos mecanismos da vida até tornar-se invisível. Desse modo, essa aparente dicotomia se constitui a partir de uma estrutura capilar de poder em que "ninguém é, propriamente falando, seu titular; e, no entanto, ele sempre

\footnotetext{
${ }^{5} \mathrm{~A}$ autora afirma que as diferenças individuais numa sociedade dividida em classes baseiamse em preconceitos e estereótipos sociais que tem como fundamento a defesa da tese da inferioridade persistente em toda a história do pensamento humano para justificar não só o fracasso escolar, mas também para atribuir uma explicação racional para uma ordem social injusta pautada nas diferenças sociais, políticas e culturais. "Às vezes, nem mesmo os pesquisadores munidos de um referencial teórico-prático estão livres dela." (Patto, 2000, p.74)
} 
se exerce em determinada direção, com uns de um lado e outros do outro; não se sabe ao certo quem o detém; mas se sabe quem não o possui." (Foucault, 1979, p. 75).

Um desses lados é um rosto conhecido, é uma população negra, de baixa escolaridade e com periférica inserção no mundo do trabalho (Diniz, 2013). Não por acaso são os rostos dos manicômios judiciários, são os mesmos dos presídios, dos hospitais psiquiátricos, da periferia, da miséria, do fracasso escolar; "(...) es imposible no ver que la vasta mayoría de los explotados, de los dominados, de los discriminados, son exactaente los miembros de las "razas", de las "etnias" o de las "naciones" en que fueron categorizadas las poblaciones colonizadas (...)" (Quijano, p.438). Se a racionalidade foi construída para dominar certas camadas da população, é preciso retirá-la desse lugar privilegiado. Acredito que a loucura, enquanto manifestação de resistência ao poder e à ordem hegemônica, tem um papel fundamental na civilização. Ela carrega uma potência subversiva capaz de afetar um dos pilares da estrutura violência da nossa sociedade: a Razão.

\section{2 - A crise da Razão e o declínio da modernidade}

"É para o outro mundo que parte o louco em sua barca louca; é do outro mundo que ele chega quando desembarca." (Foucault, A história da loucura, 1978, p. 16). Era assim que, afastando-se do caminho reto da razão, a navegação marcava a divisão rigorosa e a passagem absoluta entre o mundo da razão e o da desrazão. Entretanto, falar da história da loucura ou da desrazão implica em conhecer também a história da razão.

Japiassu (2006) afirma que a Razão, esse mito unificador do Saber, da Ética e da Política, "não é um dado natural, mas um conjunto historicamente construído de procedimentos, regras e coerções" (p. 30) que visam eliminar toda desordem e toda subjetividade. Essa vontade de possuir uma visão coerente dos fenômenos e do mundo está intimamente ligada à cultura ocidental, em especial às tradições grecoromana e a judaico-cristã que apoiavam-se no racionalismo, ${ }^{6}$ nas racionalidades e nas

\footnotetext{
6 "Se por Razão entendemos um método de conhecimento fundado no cálculo e na lógica para resolver problemas postos pelo espírito humano em função dos dados que caracterizam uma situação ou determinado fenômeno; por racionalidade uma adequação estabelecida entre uma coerência lógica (descritiva ou explicativa) e determinada realidade empírica; e por racionalização a construção de uma visão coerente e totalizante do universo com base nos
} 
racionalizações compondo um sistema absoluto, como único caminho para nos conduzirmos à Verdade.

O racionalismo das Luzes, por exemplo, carregava uma ideologia da emancipação e do progresso e, na luta contra as superstições, os obscurantismos e as religiões, surgia o princípio do universalismo e o princípio da liberdade, junto com a exaltação da ideia de homem, sujeito racional e esvaziado de toda afetividade. Apesar desses princípios universais aparentarem uma intenção emancipatória, sabemos que tais ideais ainda permanecem em um plano muito abstrato e "conduzem inconscientemente, à promoção de determinada homogeneização e à quebra de inúmeras diferenças (o diferente era considerado inferior)" (Japiassu, 2006, p. 31). A questão tornou-se ainda mais problemática quando as ideias humanistas foram colocadas de lado: os indivíduos, antes concebidos como sujeitos livres, passaram a obedecer à racionalidade do Estado, da Burocracia e do Mercado. (Japiassu, 2006)

Sem o humanismo, essa nova ordem racionalizadora toma conta do mundo ocidental. Ela converteu-se em puro instrumento do poder e de dominação, apagando tudo o que era potencialmente subversivo à ordem: a subjetividade, a afetividade, a irracionalidade. É assim que a ciência, ignorando o caráter sensível do mundo, estabelece princípios de disjunção, redução e abstração, inaugurando um paradigma simplificador. (Japiassu, 2006). É verdade que a ditadura racionalizadora moderna teve seu apogeu, mas não estaria ela entrando em colapso diante da complexidade dos fenômenos da atualidade?

Como pode o homem ser feliz no interior da lógica do sistema, onde só tem valor o que funciona segundo previsões, onde seus desejos, suas paixões, necessidades e aspirações passam a ser racionalmente administrados e manipulados pela lógica da eficácia econômica que o reduz ao papel de simples consumidor? (...) Sua racionalidade tecnocientífica não transformou os homens e seres mais humanos. Pelo contrário, converteu-os em burgueses interessados muito mais num progresso desenvolvimentista voltado para o produtivismo sem freios e para um consumismo desvairado. A Razão se transformou numa racionalidade instrumental prestando culto aos meios em detrimento dos fins. (Japiassu, 2006, p. 34-35),

dados parciais ou em um princípio único, perceberemos que a aventura da Razão Ocidental produziu, a partir do século XVII, um robusto racionalismo, várias formas de racionalidades e de racionalizações." (Japiassu, 2006, p. 30) 
As promessas de uma sociedade justa, livre e fraterna não se cumpriram e provocaram um sentimento de desconfiança em relação à Razão, revelando um mundo sem horizonte fixo. Stuart Hall (2006) argumenta que as velhas identidades modernas que davam ancoragem estável no mundo social estão em declínio atualmente, provocando um duplo deslocamento - tanto do lugar social e culturalmente definido, quanto dos indivíduos em si, sendo descentrados. Para explicar o nascimento e a morte do sujeito moderno, o autor distingue três concepções de identidade que predominavam em diferentes períodos: o sujeito do Iluminismo, o sociológico e o pós-moderno.

A primeira concepção de sujeito baseia-se num indivíduo centrado e unificado, dotado de um núcleo interior que emergia desde o nascimento e se desenvolvia permanecendo essencialmente o mesmo durante a sua existência. $\mathrm{O}$ sujeito moderno significou uma ruptura importante com o passado já que a nova concepção de individualidade libertou o indivíduo da ordem divina. O Humanismo Renascentista do século XVI, a Reforma e o Protestantismo e, particularmente, o Iluminismo do século XVIII, foram movimentos importantes que marcaram o aparecimento do "sujeito soberano" libertado dos dogmas da igreja, que ocupava o centro do universo, da racionalidade, da consciência e da ação (Hall, 2006). Como já vimos, a filosofia cartesiana também teve um papel fundamental na construção dessa concepção moderna: a certeza do cogito postulada por René Descartes propôs a existência de uma descontinuidade essencial entre mente e corpo. Por meio de demonstrações filosóficas e deduções lógicas, a partir de Cogito ergo sum afirmou-se o sujeito cartesiano situado no centro do conhecimento.

Com a crescente complexidade das cidades modernas, a ascensão do capitalismo e a democracia, mas também com o desenvolvimento das ciências sociais, uma nova concepção de sujeito emergiu: o sujeito sociológico. Nesse momento, a individualidade estava pautada em uma visão mais social, pois entravam em cena as leis da política, da economia, da propriedade, do contrato e da troca que garantissem os direitos do cidadão. O indivíduo passou a ser localizado socialmente a partir dos papéis que desempenhava no trabalho ou na vida cotidiana, e sua identidade passou a ser formada pelas relações que estabelecia entre o mundo pessoal e o mundo público. Sendo assim, “essa 'internalização’ do exterior no sujeito, e essa 'externalização’ do interior, através da ação social no mundo, constituem a descrição sociológica primária 
do sujeito moderno (...)" (Hall, 2006, p. 31). Vale lembrar que essa noção embora admitisse uma identidade construída pela interação entre o eu e a sociedade, ainda não abandonava por completo a ideia de que o sujeito possuía uma essência (psicológica), concebida metaforicamente como "interior".

Com os avanços na teoria social e nas ciências humanas observaram-se algumas rupturas no discurso do pensamento moderno, descritas também como descentramentos, dentre eles destacam-se cinco. Primeiramente, o marxismo buscou enfatizar as relações sociais de produção e exploração do trabalho descartando uma visão abstrata do ser humano, que considerava a essência universal atributo singular de cada indivíduo. O segundo foi produzido pela psicanálise que, dentre outras contribuições, permitiu entender a identidade como algo não acabado e não coerente com a lógica racional, além de admitir seu caráter contraditório e simbólico, a partir dos processos inconscientes. $\mathrm{O}$ terceiro pensamento importante para esse descentramento refere-se à virada lingüística que, ao perceber a impossibilidade de fixar os significados das palavras, reconhece igualmente a própria instabilidade ocasionada pela busca de uma forma final e as perturbações pela diferença, incluindo o significado atribuído à identidade.

O quarto avanço diz respeito aos estudos de Michel Foucault que, dentre tantos trabalhos, resgatou a história do sujeito moderno e o poder disciplinar das instituições coletivas. As análises de Foucault questionam a noção de sujeito soberano, ao indicar que o sujeito moderno como conhecemos é efeito de formas historicamente dadas de exercício do poder. As instituições sociais acabavam por individualizar ainda mais o sujeito através do controle, da vigilância e da regulação de seu corpo. O quinto movimento que produziu transformações foi o feminismo. A abertura da contestação política e social permitiu questionar a distinção entre o público e o privado; debater temas novos como a divisão doméstica do trabalho, a sexualidade, família; politizar a subjetividade através das discussões de gênero (Hall, 2006). Além do feminismo, os movimentos de igualdade racial, de direitos das minorias sexuais, de minorias étnicas, entre outros movimentos, produziram um questionamento amplo ao sujeito neutro e universal da política liberal e ao sujeito de classe da política marxista. Estes movimentos foram nomeados conjuntamente como "políticas de identidade". A apresentação desses cinco descentramentos do sujeito 
moderno proposta por Hall (2006) criaram um esboço do panorama que favoreceu o surgimento do sujeito pós-moderno.

Outros autores também se dedicaram a analisar essas mudanças contemporâneas por diferentes óticas. Bauman (1999, 2005, 2007), tal como Lipovetsky (2007), apontam a inadequação do termo "pós-modernidade" já que este parece supor uma superação ou ruptura com uma época. A transição da modernidade sólida para a modernidade líquida (Bauman, 2007) ou da modernidade para a hipermodernidade (Lipovetsky, 2007) se dá de modo contínuo, ou melhor, trata-se de uma mudança muito bem adaptável aos moldes do capitalismo em sua versão mais voraz. Esses pensadores desenvolvem interessantes reflexões sobre uma sociologia da pós-modernidade - o que é diferente de uma sociologia pós-moderna. Não apresentarei aqui a síntese de todos esses pensamentos, mas há um valor didático em apontar algumas características gerais que predominam em cada um desses dois períodos. Mesmo se tratando de autores europeus, suas contribuições ajudam a esclarecer algumas dificuldades enfrentadas no processo político, econômico e social no contexto brasileiro.

Para Bauman (1999), o projeto moderno seria o plano de controle do mundo através do ordenamento racional e técnico tendo como base o controle estatal. Significa dizer que era o Estado que fornecia os critérios para avaliar a realidade, ele tudo conhecia e tudo categorizava, eliminando do mundo todas as ambivalências. "Esses critérios dividiam a população em plantas úteis a serem estimuladas e cuidadosamente cultivadas e ervas daninhas a serem removidas ou arrancadas" (Bauman, 1999, p.29). Em resumo: "A modernidade é uma máquina geradora de alteridades que, em nome da razão e do humanismo, exclui de seu imaginário a hibridez, a multiplicidade, a ambiguidade e a contingência das formas de vida concretas" (Castro-Gómez, 2005, p. 87)

Na modernidade sólida, a igualdade tinha um peso maior que a liberdade e a ciência igualmente contribuía para o controle e a eliminação das incoerências da vida. Assim, o ser humano passava a ser um objeto moldado tanto pela racionalidade legislativa quanto pela racionalidade científica e técnica. "O papel da razão científicotécnica é precisamente acessar os segredos mais ocultos e remotos da natureza com o intuito de obrigá-la a obedecer nossos de controle." (Castro-Gómez, 2005, p. 87) 
Nesse período, com a invenção de relógios e calendários padronizados, o tempo era ordenado: uma hora de trabalho de um indivíduo vale uma hora de trabalho de outro indivíduo. Tudo seria quantitativamente mensurável, jornada por jornada sob constante vigilância: "o tempo é tudo e o homem não é mais nada" (Minkowski, 1927/2002, p. 22, tradução da autora).

O surgimento do mundo das telecomunicações e da informática e a compressão espaço-tempo favoreceram a construção de novas culturas e, por consequência, o aparecimento de novas organizações subjetivas. As transformações advindas do processo de globalização (Hall, 2006), a lógica da sociabilidade líquida (Bauman, 2007) e espetacular (Debord, 1997) inauguram novas relações entre público e privado, legitimando uma cultura de observação do outro e exposição de si. A busca por novas maneiras de se viver incitadas pelo consumismo, o caráter provisório dos objetos de desejos, a constante insatisfação, o desprendimento são algumas das características que retratam a sociedade de consumo cuja lógica baseada na relação com produtos mercantis, é aplicada ao modo de se relacionar entre pessoas. Sendo assim, na "modernidade líquida", aquilo ou aqueles que não acompanham o ritmo frenético das tendências é imediatamente descartado, tornam-se desatualizados, indesejáveis, representam o lixo social. Com o encolhimento do Estado e sua perda de controle das condições sociais as angústias contemporâneas parecem se alastrar: depressão, pânico, ansiedade (Bauman, 2007); uma explosão de diagnósticos patrocinados pela enorme indústria farmacêutica.

O Estado além de deixar de ser o garantidor da relação entre capital e trabalho, confirma a exclusão que se dá pelo jogo das relações sócio-econômicas. A esse movimento, Boaventura de Sousa Santos (1999) chamou de desnacionalização do Estado, em função da sua perda na capacidade de regulação da economia política nacional; e a desestatização do Estado, com uma nova articulação entre a regulação estatal e não estatal, entre o público e o privado, uma nova relação de trabalho entre o Estado, o mercado e a comunidade. "O trabalho perde sua eficácia como mecanismo de integração num sistema de desigualdade para passar a ser um mecanismo de reinserção, num sistema de exclusão." (p. 27)

Se antes a vida era organizada em torno do trabalho e da produção, hoje estamos sob a lógica da sociedade do consumo. "Não é necessário ser 'de esquerda' 
para observar o quanto as tendências econômicas e as inovações tecnológicas tem custado em matéria de instabilidade, desemprego e exclusão" (Alves, 2005, p. 26). Se antes o Estado que antes era portador de mensagens igualitárias e emancipatórias, torna-se simples gestor da competitividade econômica interna; se antes o proletariado precisava ser mantido com um mínimo de condições de subsistência, o pobre hoje é responsabilizado e estigmatizado pela própria pobreza. Consequência: a classe média num contexto de insegurança generalizada cobra dos legisladores penas aumentadas para o criminoso comum. (Alves, 2005). O excluído não é contemplado pela proteção mínima do Estado (Bauman, 2007). A lei não protege para aqueles que ela considera "fora da lei"; tal como a loucura, a criminalidade, a marginalidade, a pobreza, estão localizadas abaixo da linha de direitos humanos.

É notável que, em tempos de liquidez, volatilidade e incertezas, o próprio termo "direitos humanos" gera certo embaraço, pois parece remeter a um "humanismo metafísico" sem fundamento, ultrapassado e distante da realidade. Desprovido de capacidade unificadora, a política ineficaz passa a ser vista com maus olhos, pois abriga as corrupções; o Estado perde até mesmo sua função identitária e o indivíduo busca outros tipos de "comunidade" correndo o risco de transformar-se em fundamentalismos, tal como acontece com a política das identidades, por exemplo. Com a comunidade nacional inconsistente e a classe social fluida, uma comunidade internacional estaria em contradição com os particularismos de cada um. Num contexto de multiculturalismo, torna-se um grande desafio conciliar a irredutibilidade dos particularistas e a noção dos direitos humanos. (Alves, 2005)

Com a base da modernidade abalada, estamos vivendo um momento de crise do sujeito. Fala-se dela por todos os lados, por vezes caindo em uma certa banalização: a crise do capitalismo, a crise de valores, a crise existencial, a crise psicótica... Mas afinal, o que a crise representa? Para responder a essa questão é necessário ampliar o conceito e ir além das visões pejorativas sobre termo. Carregada de elementos, a palavra krisis em sua origem grega caracteriza um estado no qual uma decisão tem que ser tomada; kri, em sua origem sânscrita significa desembaraçar, purificar; em português, crisol, palavra de mesma origem, é o elemento químico capaz de purificar o ouro, limpando-o de outros elementos que se fixaram no metal pelo seu processo histórico. (Ferigato, Campos, \& Ballarin, 2007). Segundo Foucault (1979), a noção médica de crise era concebida como um momento da verdade em que a 
natureza profunda da doença subia e se deixava ver, uma ocasião estratégica: "é o momento em que o processo doentio, por sua própria energia, se desfaz de seus entraves se liberta de tudo aquilo que o impedia de completar-se e, de alguma forma, se decide a ser isto e não aquilo, decide o seu futuro - favorável ou desfavorável" (p. 114).

O rompimento da homeostase faz da experiência da crise uma oportunidade de crescimento, ela aponta para a possibilidade de superação de abstrações contidas na lógica da modernidade e indica a construção de uma nova subjetividade. Esse desequilíbrio transitório pode ser o momento oportuno para a fundação de uma nova episteme, não-dogmática e não-violenta. (Carbonari, 2007). "A crise atual da modernidade é vista pela filosofia pós-moderna e os estudos culturais como a grande oportunidade histórica para a emergência dessas diferenças largamente reprimidas" (Castro-Gómez, 2005, p. 87). Um momento para "desembaraçar" as amarras colonizadoras de nossa história e incluir outros sujeitos que tiveram seus direitos e afetos negados.

\section{3 - Colonialidade, modernidade e manicomialidade}

Sabemos que a Declaração Universal dos Direitos Humanos, proclamada pelas Nações Unidas em 1948, cumpriu um importante papel na história da humanidade, ela proporcionou base legislativa para lutas políticas pela liberdade, pela positivação dos direitos de cidadania e deu esperanças aos oprimidos. A Declaração que se fundamenta no reconhecimento da dignidade humana e "seus direitos iguais e inalienáveis" apresenta em seu artigo primeiro: "todas as pessoas nascem livres e iguais em dignidade e direitos. São dotadas de razão e consciência e devem agir em relação umas às outras com espírito de fraternidade". (Alves, 2005)

Apesar dos louváveis fundamentos da liberdade, da justiça e da paz no mundo, a Declaração Universal dos Direitos Humanos não foi "universal" sequer em sua gestação. Em um foro composto de 56 Estados ocidentais ou "ocidentalizados", a Declaração foi adotada sem consenso, deixando sem voz os países afro-asiáticos. A ideia de que os direitos humanos são de concepção “ocidental”, é inegável, afinal, ela está associada ao desenvolvimento histórico registrados na Europa e nos EUA. Todavia, essa leitura não implica em afirmar que o documento é irrelevante a sociedades com valores histórico-culturais distintos. O Direito é um discurso 
normativo de legitimação do poder estatal e de conformação da realidade. As pessoas não nascem "livres e iguais" e tais direitos não são respeitados em nenhuma comunidade nacional, real ou imaginada ${ }^{7}$. Vale lembrar que a Declaração não é uma fórmula mágica, é uma Grande Narrativa que precisa ser fortalecida ${ }^{8}$. (Alves, 2005)

Toda configuração do campo político-social está intrinsecamente relacionada à moral e a lei de nossa época. Significa dizer que as tradição, os costumes e os mecanismos de ratificação de leis são sistemas que interagem entre si, influenciandose mutuamente (Segato, 2006).

Ambos os sistemas normativos têm em comum o fato de que são positiváveis, substantivos, podendo expressar-se em um elenco de regras ou em uma lista de mandamentos estabelecidos, seja pela tradição e pelo costume, seja por intermédio de um contrato moderno - não necessariamente igualitário entre os setores que convivem e fazem parte de uma mesma sociedade. Esta positividade os fixa como repertório de normas, sem que isso exclua a possibilidade de algumas inconsistências e ambigüidades em ambos os sistemas (p. 220).

Partindo do pressuposto de que a lista dos direitos do homem se transforma conforme as condições históricas, sendo construída a partir das necessidades, dos interesses e das classes no poder, podemos afirmar que a lei é produto de lutas sociais e negociações (Segato, 2006). No entanto, o estabelecimento de leis não extinguirá, por si só, a produção de vítimas pela violação dos direitos humanos. Entende-se por vítima, em termos ético-filosóficos, como aquele

que está numa situação na qual é inviabilizada a possibilidade de produção e reprodução de sua vida material, de sua corporeidade, de sua identidade cultural e social, de sua participação política e de sua expressão como pessoa, enfim, da vivência de seu ser sujeito de direitos. (Carbonari, 2007, p. 170).

O não-reconhecimento da dignidade do sujeito que sofre a violação frequentemente desencadeia um paternalismo reprodutor da própria situação de vitimização. Para romper com esse processo, é fundamental compreender a fundo a problemática do sujeito de direitos, compreender a relação de reconhecimento de uma alteridade negada - corporeidade concreta, excluída e vitimizada - que exige diferenciação. Para tanto, devemos encontrar caminhos históricos, sociais, políticos,

\footnotetext{
${ }^{7}$ Ver discussão de Hall (2006) sobre Nação enquanto comunidade imaginada.

${ }^{8}$ Tal como foi nas grandes Conferências (de Viena, sobre direitos humanos; de Cairo, sobre populações; de Copenhague, sobre desenvolvimento social; de Beijing, sobre a mulher; de Instanbul, sobre assentamentos humanos). (Alves, 2005)
} 
econômicos e culturais capazes de viabilizar a superação da indiferença, das vitimizações propondo alternativas que emergem das próprias vítimas que se compreendem como sujeitos ético (Carbonari, 2007, p.170).

Acredito que para trilharmos tais caminhos precisamos aprender a constestar a própria lei, criar certo distanciamento de nosso leito cultural para refletir criticamente sobre os códigos morais que nos regem. Assim, torna-se indispensável incorporar à justiça um princípio distante tanto da moral quanto da lei, um princípio que nos permita desconfiar de nossas próprias crenças. A esse movimento inquieto, contrastante com estabilidade das normas, Segato (2006) denominou impulso ético. Essa pulsão amplia nossa disponibilidade existencial para um outro, assumindo um papel humanizador, uma função transformadora nas comunidades morais das quais nós fazemos parte.

Segundo a autora, no interior de uma mesma comunidade moral pode existir mais de uma sensibilidade com relação à ética, podendo ser dividida de forma simplista em em duas posições: a ética dos conformistas e a dos desconformes, a dos sensíveis às margens (o que se encontra do outro lado das muralhas de contenção da "normalidade" moral do grupo) e às vítimas e a dos não sensíveis a elas" (p. 223). Sendo assim, a ética da incomodidade ou ética da insatisfação nos interpela a uma abertura voluntária à perplexidade que abala nossas certezas em que o mundo dos outros é o apontador de nossa própria falibilidade.

Segato (2006) parte do entendimento de que ética não se resume um sistema de regras de comportamento ou de padrões positivos que poderiam justificar a desaprovação dos outros, ao contrário, a ética diz respeito à uma sensibilidade ou atitude com relação ao que é alheio aos nossos valores e às categorias que organizam nossa realidade. De forma semelhante, Carbonari (2007) abre mão de abstrações formais e regulações normativas para destacar a compreensão de sujeito de direitos enquanto construção relacional. A intersubjetividade e o reconhecimento dos sujeitos como seres livres e autônomos são pontos fundamentais para se discutir a noção de emancipação e alteridade. Trata-se de compreender a liberdade e a autonomia como processo de constituir-se com os outros a partir dos outros superando dimensões reducionistas de uma liberdade privada e privatista. Isso implica não só numa nova reconfiguração da concepção de liberdade enquanto construção substantiva da 
subjetividade aberta e relacional, mas um novo sentido de sujeito de direitos humanos, uma nova subjetividade e uma nova institucionalidade, numa perspectiva aberta, dialógica e participativa, com espaço para a diversidade solidária, em respeito ao sujeito quanto à sua singularidade (em sua trajetória pessoal, em sua corporeidade), sua particularidade (sua situação concreta, histórica, carregada de vivências) e seu universalismo (expressão da dignidade humana).

Essa discussão de uma nova cultura dos direitos humanos é imprescindível no campo da saúde mental para a proteção dos direitos e reparação de todas as formas de violação e precariedade. Utilizo esse último conceito apresentado por Butler (2006) para pensar a corporeidade nos debates de grupos subalternizados, em especial "o louco". "Vida precaria es un intento de aproximación a la cuestión de una ética de la no violencia, basada en la comprensión de cuán fácil es eliminar la vida humana" (Butler, 2006, p. 20). Nesse debate, também é preciso problematizar as representações midiáticas que nos autoriza a respondermos de modo insensível a essa vida que eliminamos, que é se localiza no campo de visibilidade publicamente reconhecido.

Ser um corpo é estar exposto a forças sociais e políticas, a exigências de sociabilidade tais como a linguagem, o trabalho e o desejo. No entanto, a capacidade epistemológica de apreender ${ }^{9}$ uma vida está parcialmente dependente de que essa vida seja produzida segundo a norma, sem distinções, para que nossa capacidade seja capaz de disserni-lo e nomeá-lo. A autora aponta que essas condições normativas para a produção dos sujeitos são construídas e desconstruídas segundo operações mais amplas de poder que determinam aqueles que são e os que não são reconhecidos completamente como sujeitos. As condições normativas de reconhecibilidade não são permanentes, não porque a vida apresenta em sua essência uma resistência à normatividade, mas porque tais construções demandam tempo para se constituir, são variáveis e históricas. (Butler, 2006).

A reconhecibilidade, segundo Butler (2006), não se caracteriza como um potencial humano e universal presente em cada indivíduo, já que, se assim o fosse, todos seriam automaticamente reconhecidos como sujeitos. A reconhecibilidade

\footnotetext{
${ }^{9}$ A autora demarca a diferença entre "apreender" e "reconhecer". Este último derivado de textos hegelianos, é um termo mais forte, enquanto a "apreensão" pode marcar, registrar ou reconhecer sem o pleno reconhecimento.
} 
precede o reconhecimento, ela caracterizará as convenções e as normas, ou seja, as condições mais gerais que moldam um sujeito para o reconhecimento e o tornam reconhecível. O entendimento sobre o funcionamento da reconhecibilidade e das normas é imprescindível para que sejam levantadas questões sobre a construção de uma sociedade democrática:

Sin embargo, se trata de saber cómo operan tales normas para hacer que otras sean decididamente más difíciles de reconocer. El problema no es meramente cómo incluir a más personas dentro de las normas ya existentes, sino considerar cómo las normas ya existentes asignan reconocimiento de manera diferencial. ¿Qué nuevas normas son posibles y cómo son producidas? ¿Qué podría hacerse para producir una serie más igualitaria de las condiciones de reconocibilidad? En otras palabras, ¿qué podría hacerse para cambiar los términos mismos de la reconocibilidad con el fin de producir unos resultados más radicalmente democráticos? (Butler, 2011, p. 20)

Os esquemas da inteligibilidade, condicionados pelo seu tempo, produzem normas de reconhecibilidade que preparam o caminho do reconhecimento. Cada caso de vida normativa é sombreada pelo seu próprio fracasso e, mesmo que essa transgressão torne-se viva, ainda não é reconhecida como vida, é uma alteridade interrompida (Butler, 2006). Nesse ponto, retomo o debate sobre a loucura, expressão humana que excede a inteligibilidade e a norma, marcando o contraponto do sujeito da Razão - pautado na racionalidade científica hegemônica baseada nos princípios de causalidade e previsibilidade. O sujeito que sofre, que delira, ainda é compreendido como o sujeito da desrazão e raramente ocupa a posição de cidadão. Sem dúvida esse assujeitamento trouxe e traz graves implicações no campo dos direitos humanos.

A desrealização do outro, conforme aponta Butler (2006), representa uma condição de espectro, um outro que não está vivo nem morto e, por isso, não se qualifica como vida, não merece ser sepultado pois é inseputável mesmo. Foucault (1978) afirmava que "a loucura é o já-está-aí da morte" (p. 21), já que, seguindo a continuação rigorosa da lepra, representava em vida a própria presença da morte. Entretanto, a questão central não se reduz a um discurso desumanizador que produz efeitos devastadores, mas também diz respeito sobre a própria existência de limites para o discurso que estabelecem fronteiras da inteligibilidade humano e um campo de visibilidade publicamente reconhecido. "No sólo se trata de una muerte pobremente marcada, sino de muertes que no dejan ninguna huella (...)." (Butler, 2006, p. 61). 
Vale lembrar, entretanto, que nem sempre a loucura foi sinônimo de isolamento e exclusão. No período da Antiguidade e da Idade Média, a loucura era experimentada livremente, fazia parte do cenário comum na Grécia e Roma. Nas famílias de posse, os loucos permaneciam em casa, frequentemente sob a guarda de um assistente especialmente contratado. Já os pobres, circulavam sobrevivendo através da caridade pública ou pequenos trabalhos realizados para particulares. Curiosamente, na América Colonial, os governos municipais remuneravam as famílias de lavradores que se dispunham a receber os loucos pobres não incapacitados. Tal prática foi precursora do sistema "assistência heterofamiliar" que apareceria mais tarde como parte do armamentário terapêutico psiquiátrico. $\mathrm{Na}$ análise desse período, é necessário levar em consideração que o próprio conceito de loucura era mais restrito àquilo que era diretamente observável, além disso, as populações reduzidas e a curta duração média de vida são fatores que nos levam a supor que o número de loucos era menor (Tundis \& Costa, 2000).

É interessante notar que a loucura até então não recebia o peso do estigma ${ }^{10}$ que conhecemos hoje. Um dos fatores que certamente contribuiu para esse configuração era a própria lógica peculiar das sociedades pré-capitalistas. A determinação do normal e do anormal não estava baseada no critério de aptidão e inaptidão para o trabalho. As formas de organização do trabalho nessas sociedades eram pouco discriminativas para as diferenças e acomodavam largas variações individuais. $\mathrm{O}$ artesanato, por exemplo, valorizava o ato de se exprimir diferentemente e talvez por isso esteja atualmente tão presente nas oficinas terapêuticas (Tundis \& Costa, 2000).

Seguindo a linha do tempo, no fim do século XV na Europa, a rotina rural foi drasticamente modificada com o fim do campesinato. Durante esse processo de migração ao cenário urbano novos personagens surgiram: mendigos, desocupados e vagabundos. O imperativo "viver para trabalhar" instaurava uma forte repressão aos

\footnotetext{
${ }^{10} \mathrm{O}$ estigma é definido por Goffman (1988) como um atributo profundamente depreciativo que pode servir para confirmar a normalidade de outro grupo. Será útil resgatar a distinção que o autor faz sobre três tipos diferentes de estigma. O primeiro diz respeito à abominação do corpo, a segunda são as culpas de caráter individual, e o terceiro relacionado às características sociológicas, quando o indivíduo apresenta uma característica diferente do que previam e, por consequiência, acaba sendo afastado de seu grupo. A própria proximidade com o grupo reconhecido como normal pode reforçar sentimentos como auto-exigências ou autodepreciação, eco das relações baseadas no seu não-reconhecimento.
} 
ociosos, aqueles que não se inscreviam na moralidade eram severamente punidos. Surrados com chicotes, marcação no corpo com ferro em brasa e até pena de morte eram práticas comuns. (Tundis \& Costa, 2000; Bezerra Jr, 2007). O sistema capitalista inaugurou uma nova utilização do corpo nas relações de trabalho, novas relações entre o domínio público e o privado, novos equipamentos sociais propagadores de ideais de uma burguesia. Surge então um modo-indivíduo de subjetividade voltado para o funcionamento (Torre \& Amarante, 2001).

Levando em consideração tais mudanças, conforme apontado por Torre e Amarante (2001), "analisar a história da loucura remete à análise de como a modernidade se constitui como forma de pensamento e organização social e como ela forja uma forma de lidar com a loucura como fenômeno humano e social" (p. 74). Significa dizer que as próprias configurações de saberes e do poder disciplinar como forma de controle é resultado de um processo contínuo de normatização dos corpos, em que o critério de exclusão dos desviantes torna-se parte da engrenagem do sistema moderno/colonial.

Sem dúvidas, a colonialidade é o outro lado da modernidade (Baldi, 2012; Segato, 2013; Castro-Gómez, 2005). Há de se reconhecer o estreito vínculo entre o racismo, eurocentrismo, capitalismo e modernidade articulados pela estrutura de colonialidade. Esse conceito não diz respeito apenas sobre dominação formal do colonialismo político, mas revela também a profundidade e continuidade de classificações sociais e relações hierárquicas de poder conformadas pela expansão colonial. (Castro-Gómez, 2005) Significa dizer que, apesar de sua origem datada, o colonialismo europeu fez emergir estruturas de poder globais que deram condições para a colonialidade, uma matriz que tornou-se estável e duradoura, que gerou um tipo de poder disciplinar característico das sociedades e das instituições modernas.

A "racionalidade moderna", o "Estado-Nação", a "família burguesa" são elementos que articulam-se juntos, compondo uma estrutura que Aníbal Quijano (2007), denominou de colonialidade do poder. Essa matriz de dominação, em relação íntima com o poder capitalista, funda a imposição de uma classificação racial/étnica, uma categoria mental moderna, em que a hegemonia eurocêntrica assume uma supremacia determinante sobre todas as demais classificações, uma suposta totalidade 
que governa o comportamento do todo e de cada uma das partes. Significa dizer que, a ordem explícita do colonialismo político, mesmo sendo eliminada, instaurou uma relação de dominação, exploração e uma sistemática repressão de todos os modos de existir que não servem ao modelo colonial.

"La represión recayó ante todo sobre los modos de conocer, de producir conocimiento, de producir perspectivas, imágenes y sistemas de imágenes, simbolos, modo de significación; sobre los recursos, patrones e instrumentos de expresión formalizada y objetivada, intelectual o visual. (...) Entonces, la cultura europea se convertió además en una seducción; daba acceso al poder. Después de todo, más allá de la represión, el instrumento principal de todo poder es su sedución. La europeización cultural se convertió en una aspiración" (Quijano, 1992, p. 438-439).

Foi assim que, através da expressão dos dominantes/colonizadores, foi fabricada uma imagem mistificada de padrões, baseada num modelo europeu universal, longe do acesso dos dominados. Os colonizados eram forçados a aprender a cultura dos dominadores para a reprodução da dominação, no campo da atividade material, tecnológica, subjetiva e religiosa. Significa dizer que a instrumentalização da razão pelo poder colonial não só produziu paradigmas distorcidos de conhecimento, mas opera, ainda hoje, um princípio constitutivo organizador de controle sobre a natureza, sobre os corpos, sobre o sexo, sobre o trabalho, sobre a identidade, sobre as formas de autoridade. (Quijano, 2007)

Acredito que o processo de apropriação da loucura pela medicina e o conceito de alienação assumem papel estratégico para a permanência de uma ordem hegemônica materializando-se em práticas, instituições e saberes. É importante compreender, mas não tomar como justificativa, como e porquê ainda existem influências tão fortes de modelos biológicos e laboratoriais em nosso campo de estudo. Nossas práticas ainda são orientadas para a busca de causas patológicas e orgânicas que culpabilizam o indivíduo a partir de perspectivas reducionistas. A psicologia é reconhecida pelo imaginário social como um campo propício para a “prevenção de desajustes" e para a adequação de indivíduos a comportamentos socialmente ajustados. As ciências, de modo geral, apesar de terem questionado o discurso teocêntrico e a autoridade religiosa, reproduzem práticas discriminatórias a partir de pressupostos de neutralidade e incontestabilidade da autoridade científica (Citeli, 2001). A isso soma-se ainda a relação (tensa) entre a mídia e o discurso 
científico. Portanto, essas teorias não refletem a natureza humana, mas sim, a ideologia daqueles que a criaram. A ciência projeta o universo cultural, moral e político de seu tempo como natural e, por isso mesmo, ajuda a legitimá-lo" (p. 143). Se o indivíduo é doente segundo a classificação e sua sociedade e de acordo com critérios e modalidades que ela fixa, pode-se dizer que a doença é um construção social (Ferreira, 1995).

A verdadeira superação de um modelo tradicional psiquiátrico implica na redefinição do lugar do sujeito da diferença na sociedade, ou seja, implica numa desmontagem político-social da construção do lugar da diferença como um lugar inferior e do papel social destinado ao alienado. (Torre \& Amarante, 2001). Pensar o sujeito que sofre como construtor de projetos e subjetividades, cidadão que participa e interfere no campo político pode parecer distante quando nos deparamos com a lógica contraditória e excludente de uma cidadania moderna.

A Reforma Psiquiátrica no Brasil é um processo político e social complexo em que diferentes atores, instituições e forças atuam em diferentes territórios: nos governos federal, estadual e municipal, nas universidades, nos serviços de saúde, nos conselhos profissionais, nas associações de pessoas com transtornos mentais e de seus familiares, nos movimentos sociais, nos territórios do imaginário social e da opinião pública (Brasil, 2005; Mesquita, Novellino, \& Cavalcanti, 2010). Para compreender os desafios que surgem nesse contexto e traçar estratégias eficientes no campo da saúde mental, é fundamental resgatar a história da loucura e da cidadania no Brasil.

A fim de evitar exaustivas reconstituições históricas afastando-se do tema central, apresentarei a seguir algumas tendências políticas pertinentes para essa discussão. Trata-se de uma breve contextualização para introduzir o debate sobre saúde mental e comunicação na atualidade.

\subsection{1 - A construção da cidadania no Brasil}

O fenômeno da cidadania é complexo e historicamente definido, teve sua origem datada da Revolução Francesa, no contexto de uma luta política nacional no seio do Estado-Nação. A cidadania em sua configuração ocidental, moderna e burguesa se descobra em três tipos de direitos: civis, políticos e sociais. Os direitos civis são os direitos fundamentais à vida, à liberdade, à propriedade, à igualdade perante a lei. Os direitos políticos se referem à participação do cidadão no governo da 
sociedade. Seu exercício é limitado a parcela da população e consiste na capacidade de fazer demonstrações políticas, de organizar partidos, de votar, de ser votado. Os direitos sociais garantem a participação no governo da sociedade, a participação na riqueza coletiva, incluem o direito à educação, ao trabalho, ao salário justo, à saúde, à aposentadoria. (Carvalho, 2002). A prática da cidadania é a expressão concreta do exercício da democracia. (Pinsky \& Pinsky, 2007).

Ser cidadão pleno é ter direito à vida, à liberdade, à propriedade, à igualdade perante a lei, entretanto, não podemos afirmar que exista uma sequência única e determinista no processo ampliação de direitos ao longo da história. "Cidadania não é uma definição estanque, mas um conceito histórico, o que significa que seu sentido varia no tempo e no espaço" (Pinsky \& Pinsky, 2007, p. 6). Do mesmo modo, Carvalho (2002) aponta que a evolução da cidadania não se dá forma linear e uniforme, mas é marcada por desvios, avanços e retrocessos de acordo com acontecimentos específicos de cada Estado-Nação.

Pode-se dizer que o processo de cidadania no Brasil se deu de modo inverso se comparado à cronologia e a lógica de outros países como a França, Inglaterra e EUA. De modo geral, a cidadania brasileira começou a se constituir a partir dos direitos sociais implantados em tempo de supressão dos direitos políticos e de redução dos direitos civis. (Pinsky \& Pinsky, 2007). Nossa trajetória peculiar e nossa política de excessiva valorização do Poder Executivo e de impaciência com o funcionamento geralmente mais lento do mecanismo democrático de decisão tem levado à busca de soluções mais rápidas por meio de lideranças carismáticas e messiânicas. Estabelecemos uma relação é verticalizada em que o Estado é sempre visto como todo-poderoso: na pior hipótese como repressor e cobrador de impostos, na melhor, como um distribuidor paternalista de empregos e favores. Vemos que essa inversão produziu diferenças qualitativas na configuração atual da cidadania nacional, resultado do peso do passado que ainda se fazem sentir no Brasil de hoje.

Em três séculos de colonização (1500-1822), os portugueses tinham construído um enorme país dotado de unidade territorial, lingüística, cultural e religiosa. Mas tinham também deixado uma população analfabeta, uma sociedade escravocrata, uma economia monocultora e latifundiária, um Estado absolutista. À época da independência, não havia cidadãos brasileiros, nem pátria brasileira. (Carvalho, 2002, p. 18)

A independência de Portugal em 1822 cumpriu seu papel comercial e deixou como efeito imediato dessa conquista a dominação e o extermínio, a escravização e a 
morte de milhões de indígenas ${ }^{11}$. A base escravista da sociedade colonial penetrava todas as classes: o Estado, os funcionários públicos, as ordens religiosas, os padres, todos eram proprietários de escravos. A falta do próprio sentido da cidadania e da igualdade era tão generalizada que o próprio escravo liberto, embora repudiasse sua escravidão, admitia escravizar os outros. A essa falta de consciência de direitos, tanto dos escravos, quanto dos senhores, somava-se ainda o descaso pela educação primária. Após a saída dos jesuítas em 1759, não havia iniciativa a favor da educação "não era do interesse da administração colonial, ou dos senhores de escravos, difundir essa arma cívica." (Carvalho, 2002, p. 23).

Aos escravos libertos não havia escolas, nem terras, nem empregos. Muitos regressavam às fazendas para retomar ao trabalho bruto por baixos salários. "A população negra teve que enfrentar sozinha o desafio da ascensão social, e frequentemente precisou fazê-lo por rotas originais, como o esporte, a música e a dança". (Carvalho, 2002, p. 53). Talvez esses sejam os primeiros indícios da arte e da cultura como recursos de resistência, tal como veremos na temática da saúde mental.

No período colonial, a preocupação da elite com a ordem social levou à escolha de uma solução monárquica que não se sustentou por muito tempo sem um sentido de nacionalidade e com a grande maioria da população excluída de seus direitos: "os direitos civis beneficiavam a poucos, os direitos políticos a pouquíssimos, os direitos sociais ainda não se falava, pois a assistência social estava a cargo da Igreja e de particulares" (Carvalho, 2002, p. 24).

Apesar de constituir um avanço no que se refere aos direitos políticos, a independência do Brasil não representou uma mudança radical no panorama. Com a ausência de um poder que pudesse ser chamado de público, ou seja, que garantisse a igualdade de todos, o povo, em posição de espectador, assistiu a manutenção da escravidão e suas consequentes limitações aos direitos civis. (Carvalho, 2002) A vida social no Brasil estava fortemente polarizada em dois extremos, de uma lado os senhores e proprietários, de outro lado, os escravos. Posteriormente, entre esses,

\footnotetext{
11 "Calcula-se que havia na época da descoberta cerca de 4 milhões de índios. Em 1823 restava menos de 1 milhão. Os que escaparam ou se miscigenaram ou foram empurrados para o interior do país. A miscigenação se deveu à natureza da colonização portuguesa: comercial e masculina." (Carvalho, 2002, p. 20)
} 
surgia uma população indefinida de maioria negra, mulata e mestiça. Não eram mais escravos, nem podiam ser proprietários, formavam uma subcategoria, a mais degradada, incomoda e nociva que tornou-se alvo de preocupações constantes das autoridades. (Tundis \& Costa, 2000)

No intervalo de 1822 até 1930 as eleições aconteciam ininterruptamente, mas, se por um lado representavam um grande avanço em relação à situação colonial, por outro, a população não alfabetizada era encurralada. Na sociedade rural, dominavam os grandes proprietários - os mesmos proprietários de escravos antes de 1888. Eles faziam aliança com comerciantes urbanos, que sustentavam a política do coronelismo que fazia do voto um ato de obediência forçada. Pouco a pouco os votantes ao perceberam a importância do voto para os chefes políticos começaram a vendê-lo mais caro: A eleição era a oportunidade para ganhar um dinheiro fácil, uma roupa, um chapéu novo, um par de sapatos. No mínimo uma boa refeição" (Carvalho, 2002, p. 35-36).

Os proprietários rurais que precisavam manter um grande número de dependentes para a finalidade eleitoral se preocupavam com o custo crescente das eleições queriam combater o voto ampliado. Foi assim que os avanços adquiridos com a Constituição de 1824 deram um passo para trás: o direito ao voto, agora direto, excluiu os analfabetos, as mulheres, os mendigos, os soldados, os membros das ordens religiosas. Com a lei liberal de 1881, o povo - e não as elites - foi responsabilizado pela corrupção eleitoral e teve sua participação política restringida. Mas a "república dos coronéis" não se extinguiria, as práticas eleitorais fraudolentas seriam então aperfeiçoadas. (Carvalho, 2002)

Seja no Império, seja na República o povo não tinha lugar no sistema político e nem havia um sentimento nacional consolidado. Pode-se dizer que movimentos reativos às medidas do governo indicavam um esboço de cidadão que, mesmo sem ter consciência clara do sentido do voto, tinha alguma noção sobre direitos dos cidadãos e deveres do Estado. Conforme Carvalho (2002), esse era o prenúncio de uma cidadania, ainda que em negativo.

Algumas mudanças sociais e políticas começaram a surgir a partir de 1930 até 1964, como a criação do Ministério do Trabalho, Indústria e Comércio e, com ele, a legislação sindical, trabalhista e previdenciária, o voto secreto e o direito de voto estendido às mulheres em 1934. Esse período de ampliação dos direitos sociais 
referiam-se basicamente aos direitos dos trabalhadores que cumpriam a função de estabelecer um contrato da força de trabalho. Essa intervenção estatal baseada num modelo de cidadania vinculado ao trabalho dividia a classe operária, pois acabava deixando de lado uma grande parcela da população que não seria reconhecida em lei. Diversos trabalhadores que exerciam atividades, como os trabalhadores rurais, não eram considerados cidadãos; ou ainda, em uma mesma categoria haviam desigualdades em relação ao acesso aos benefícios sociais. (Carvalho, 2002).

Nesses anos em que se estabelecia uma legislação marcada por ambiguidades, começava a aparecer o populismo, um fenômeno urbano que, na medida em que trazia as massas para a política, colocava os cidadãos em posição de dependência perante os líderes, pois votavam em lealdade pessoal pelos benefícios que esses supostamente lhes tinham distribuído. "A cidadania que daí resultava era passiva e receptora antes que ativa e reivindicadora" (Carvalho, 2002, p.126).

Se antes de 1964 observamos alguns avanços no sistema democrático, com o Golpe Militar os partidos políticos que existiam desapareceram, assim como os sindicatos; os meios de comunicação foram censurados e pessoas foram perseguidas, torturadas, fuziladas, marcando um cenário sangrento de repressão e coerção dos indivíduos. Até 1974, apesar dos governos militares investirem na expansão dos direitos sociais, as medidas repressivas restringiam os direitos civis e políticos. Esso Brasil viveu uma rápida expansão da economia brasileira e uma grande transformação demográfica em função do deslocamento de população do campo para as cidades. Entretanto, a composição da oferta de empregos beneficiou de maneira muito desigual os vários setores da população fazendo com que as desigualdades crescessem ao invés de diminuírem.

Felizmente, alguns fatos marcaram o despertar da consciência de direitos e serviram para a formação de lideranças políticas chegando ao auge da mobilização popular em 1984. São exemplos: o fim da censura prévia e a volta dos primeiros exilados políticos, em 1978; a enorme expansão dos movimentos sociais urbano, especialmente de moradores e favelados; a votação de uma lei de anistia, em 1979; fim do bipartidarismo forçado; criação do Partido dos Trabalhadores (PT); e as eleições diretas para governadores de estados. "A campanha das diretas foi, sem dúvida, a maior mobilização popular da história do país, se medida pelo número de pessoas que nas capitais e nas maiores cidades saíram às ruas" (Carvalho, 2002, p. 
188). O Movimento dos Sem-Terra (MST) também teve alcance nacional e mostrou que, através do direito de organização era possível entrar nas arenas políticas apontando caminhos de democratização do sistema.

Pode-se afirmar que o esforço de reconstrução, ou melhor, de construção da democracia no Brasil recebeu atenção após o fim da ditadura militar, em 1985. Após 178 anos de história marcada por avanços, retrocessos e ambiguidades para construir o cidadão brasileiro, ainda observamos problemas econômicos sérios como a desigualdade e o desemprego, problemas sociais também graves na educação, nos serviços de saúde e saneamento, além da violência urbana. Certamente a inversão dos direitos teve impacto na formação da cidadania brasileira e favoreceu uma visão corporativa dos interesses coletivos em que "os benefícios sociais não eram tratados como direitos de todos, mas como fruto da negociação de cada categoria com o governo. A sociedade passou a se organizar para garantir os direitos e os privilégios distribuídos pelo Estado" (Carvalho, 2002, p. 223). Infelizmente, o processo de prática política posterior à redemocratização mostra que as grandes corporações de banqueiros, comerciantes, industriais, todos se movimentam para que seus privilégios prevaleçam. Mais detalhadamente, pode-se dizer que:

A formação do cidadão como "sujeito de direito" somente é possível dentro do contexto e da escrita disciplinar e, neste caso, dentro do espaço de legalidade definido pela constituição. A função jurídico-política das constituições é, precisamente, inventar a cidadania, ou seja, criar um campo de identidades homogêneas que tornem viável o projeto moderno da governamentabilidade. A aquisição da cidadania é, então, um funil pelo qual só passarão aquelas pessoas cujo perfil se ajuste ao tipo de sujeito requerido pelo projeto da modernidade: homem, branco, pai de família, católico, proprietário, letrado e heterossexual. Os indivíduos que não cumpram com estes requisitos (mulheres, empregados, loucos, analfabetos, negros, hereges, escravos, índios, homossexuais, dissidentes) ficarão de fora da "cidade letrada", reclusos no âmbito da ilegalidade, submetidos ao castigo e à terapia por parte da mesma lei que os exclui. (Castro-Gómez, 2005, p. 89)

Se a representação política parece não funciona para resolver os grandes problemas da maior parte da população, Carvalho (2002) aponta como um caminho possível para a consolidação democrática o fortalecimento da organização da sociedade. $\mathrm{O}$ autor nos lembra que essa democratização do poder não deve ser feita contra o Estado em si, mas "ela deve ser feita contra o Estado clientelista, corporativo e colonizado" (p. 227). 
Diante das desigualdades sociais que seguem como herança deixada pela escravidão, pensar essa democratização requer um enorme esforço de articulação popular e consciência de cidadania. Entretanto, quando situamos essa discussão no campo da saúde mental, sabemos que as dificuldades para o "sujeito da desrazão" passar nesse funil são duplamente desafiadores. Aqueles que sofrem psiquicamente, sofrem também por questões sociais mais amplas que os atravessam, além de sofrerem pela própria alienação construída em torno do sofrimento.

\subsection{2 - Cidadania alienada: o sujeito de direitos é o sujeito do dinheiro}

O uso do termo alienação mental e a origem etimológica do termo traz nuances que merecem ser exploradas. Do latim alienare ou alienatio, encontramos diversos significados, entre eles destaco: aquele que vive à margem da sociedade; aquele que pertence a outrem; e por último, e mais interessante, tornar-se outro. (Amarante, 2013)

Tomando como análise a primeira definição, "aquele que vive à margem da sociedade", pode-se evocar novamente a história da nau dos loucos pela alusão àqueles que eram expulsos da terra para ficar às margens, em seu sentido literal e figurado. Entretanto, o alienado não se restringe a grupo de pessoas com transtornos mentais, o termo é aplicável a outros grupos igualmente segregados e subalternizados, ou seja, alienado é uma denominação que abarca todos os excluídos ou marginalizados. (Amarante, 2013)

Já a segunda definição, "aquele que pertence a outrem", põe em questão a noção de pertencimento ou de propriedade de forma mais ampla. Seja em função do seu território, sua razão, seu corpo ou sua liberdade. O alienado não é mais dono de si mesmo, torna-se coisa, objeto ou propriedade de um outro. Sabemos que a psiquiatria ao circunscrever muros em torno da figura do louco, demarcava aquilo que seria de sua propriedade, isolava o seu objeto para melhor analisá-lo. É possível expandir essa lógica em relação a outras condições que envolvem disputa ou perda de identidade de pertencimento, tal como os escravos, os refugiados, os prisioneiros, as mulheres, etc.

A terceira definição, "tornar-se outro", faz emergir uma produtiva confusão hermenêutica. A pretensão da psiquiatria e da psicologia de apropriar-se do ser 
humano enquanto objeto de estudo, produz inevitavelmente distorções em sua representação. Construir modelos abstratos e imprecisos sobre funcionamento psíquico tornou o sujeito um espectro de si, ajustando-o forçosamente a categorias de comportamentos desajustados. O alienado é, portanto, o outro assujeitado, a doença. Por outro lado, a tarefa compreensiva do psicólogo deve necessariamente passar por uma suspensão temporária de todas suas teorias e de suas pré-concepções para que, então, o outro possa surgir. Alienar-se parece ser a condição relacional para estar presente e disponível para o outro. O encontro de alteridades e reconhecimento mútuo é o primeiro passo para reverter o processo de alienação.

Sem dúvida essa postura equipolente, indispensável especialmente no campo da saúde mental, ainda se configura uma entrave para alguns profissionais que precisam lidar constantemente com seu estufado ego acadêmico, uma dificuldade herdada da ciências modernas. "Alienar-se", nesse sentido, é um mergulho profundo no sofrimento do outro por meio da atenção flutuante; é a capacidade de fazer o outro emergir, com intensidade e leveza, simultaneamente, com alguma segurança para não confundir-se completamente.

A alienação humana não é um conceito debatido exclusivamente no campo da psiquiatria. $\mathrm{O}$ termo teve sua origem na teoria marxista e refere-se a um modoindivíduo movimentado pelas engrenagens da máquina capitalista. A alienação é comumente entendida como o processo de individualização na fabricação de um produto a fim de minimizar o tempo de produção e maximizar os lucros. No período anterior ao surgimento da industrialização, por exemplo, o fabricante de cordas para violões também fabricava o violão, ele sabia como tocar e afinar o instrumento e participava de toda a sua construção. Com aceleração da produção, enquanto um operário fabrica as cordas, o outro fabrica o corpo e um terceiro, o braço. Não há mais necessidade do trabalhador aprender a tocar violão, em resumo, ele não necessita mais ter controle sobre aquilo que produz. O sujeito, então, se maquiniza.

A moderna máquina capitalista está assentada num regime de exploração: enquanto a elite branca acumula capital, o operário metalúrgico que trabalha colocando portas nos carros chega a conclusão que nunca poderá ter o produto que ajuda a produzir. Sob essa lógica, o trabalhor, que não faz mais parte da organização 
do trabalho, tem suas potencialidades reduzidas. $O$ ser humano torna-se completamente fragmentado e percebido apenas como uma ferramenta útil na produção de um produto. Vemos aí o objeto se sobrepondo ao sujeito.

O trabalhador não produz para si próprio, ele produz para um poder independente. O sucesso desta produção, a sua abundância, regressa ao produtor como abundância da despossessão. Todo o tempo e o espaço do seu mundo se the tornam estranhos com a acumulação dos seus produtos alienados. O espetáculo é o mapa deste novo mundo, mapa que recobre exatamente o seu território. As próprias forças que nos escaparam mostram-senos em todo o seu poderio. (...) $\mathrm{O}$ homem alienado daquilo que produz, mesmo criando os detalhes do seu mundo, está separado dele. Quanto mais sua vida se transforma em mercadoria, mais se separa dela. (Debord, 1997, p. 1920)

Debord (1997) apresenta o conceito de espetáculo como resultado e o projeto do modo de produção existente, como inversão concreta da vida ${ }^{12}$ ou o movimento autônomo do não-vivo. O conceito de espetáculo não deve ser entendido como complemento ao mundo real, ele é "o coração da irrealidade da sociedade real. Sob todas as suas formas particulares de informação ou propaganda, publicidade ou consumo direto do entretenimento, o espetáculo constitui o modelo presente da vida socialmente dominante." (p. 10)

Nesse sentido, o espetáculo, fomentado pelo crescimento econômico e expansão da produção industrial, se apoia na fabricação de alienação. Um sistema fechado que se apresenta como algo indiscutível e inacessível. "A forma e o conteúdo do espetáculo são a justificação total das condições e dos fins do sistema existente." (Debord, 1997, p. 10). Mesmo no tempo vivido fora da produção moderna, o trabalhador é seduzido a todo tempo pelo espetáculo e, quanto mais ele contempla inconscientemente esses modelos, menos ele vive, "quanto mais aceita reconhecer-se nas imagens dominantes da necessidade, menos ele compreende a sua própria existência e o seu próprio desejo". Isso é a alienação do espectador: quando "a exterioridade do espetáculo é incorporada de tal modo que os seus próprios gestos já não são mais seus, mas de um outro que lhos apresenta". (Debord, 1997, p. 19).

Confesso que as análises de Guy Debord, aparentemente tão distantes da

\footnotetext{
${ }^{12} \mathrm{O}$ autor, ao analisar a sociedade do espetáculo, reconhece que as condições modernas de produção e a acumulação de espetáculos provocam uma inversão da vida, em que "tudo que era diretamente vivido se esvai na fumaça da representação" (Debord, 1997, p.8).
} 
temática da saúde mental, revelaram uma impressionante proximidade em relação aos processos de institucionalização dos hospitais psiquiátricos. Sobre essa despropriação de si ou mortificação do $e u$, características da alienação, lembrei-me da fábula oriental contada por Basaglia em A instituição negada (2001):

Uma fábula oriental conta a história de um homem em cuja boca, enquanto ele dormia, entrou uma serpente. A serpente chegou ao seu estômago, onde se alojou e onde passou a impor ao homem a sua vontade, privando-o assim da liberdade. O homem estava à mercê da serpente: já não se pertencia. Até que uma manhã o homem sente que a serpente havia partido e que era livre de novo. Então, dá-se conta de que não sabe o que fazer da sua liberdade. [...] 'Em vez de liberdade ele encontra o vazio', porque "junto com a serpente saíra a sua nova essência, adquirida no cativeiro' [...]. (Basaglia, 2001, p. 132)

Essa analogia à condição institucional retrata uma relação forçosamente objetual entre o paciente e aquele que toma conta dele. Não há comunicação possível entre esses lados senão através de um rótulo. A sobreposição do objeto em relação ao sujeito e a retirada da subjetividade revelam uma realidade invertida: a questão não é mais a doença em si, mas a relação que se estabelece com ela. "A objetivação não é a condição objetiva do doente, mas se localiza no interior da relação entre doente e terapeuta, no interior, portanto, da relação entre o doente e a sociedade que delega ao médico sua cura e tutela" (Basaglia, 2001, p. 109).

Se na psiquiatria vimos a objetivação da doença desencadeando numa relação estritamente objetual, também observamos na lógica capitalista e espetacular esse mesmo apagamento do sujeito na produção maquinizada. Da sedação química à sedução do espetáculo, fica claro que a alienação tem um efeito paralisante e traduz uma relação de opressão e de violência entre o poder e o não-poder que, posteriomente, se manifesta em exclusão. "A violência e a exclusão estão na base de todas as relações que se estabelecem em nossa sociedade" (Basaglia, 2001, p. 101). As bases do capitalismo e as bases da psiquiatria se fundamento numa estrutura coercitiva, autoritária e hierárquica que transforma o sujeito em objeto de violência.

Retomando o termo "inversão da realidade" mencionado pelos autores, tanto Basaglia (2001), quanto Debord (1997) apontam como fator determinante para essa inversão a relação social estabelecida entre as pessoas. Para tornar mais clara a ideia de que as consequências da doença variam de acordo com a abordagem em relação a ela, Basaglia nomeia três tipos de relação: do tipo aristocrático, mutualista e 
institucional. Para exemplificar, vamos analisar os extremos. Na relação aristocrática o paciente possui um poder contratual que equilibra com o poder técnico do médico, ou seja, o valor econômico do sujeito sustenta sua não submissão e seu valor social. No entanto, perdendo esse poder contratual ou o seu valor de troca, ele pode iniciar a verdadeira "carreira do doente mental", estabelecendo uma nova relação: a institucional. Nessa abordagem não há reciprocidade alguma, domina o poder puro do médico em contraste e a anulação dos direitos do sujeito e, ao paciente, não há nenhuma outra alternativa de oposição exceto um comportamento anormal (Basaglia, 2001).

Nessa perspectiva, debater a alienação humana no campo da saúde mental, deve passar obrigatoriamente por uma análise política-econômica da nossa sociedade. "Um exame atento revela que a doença, enquanto condição comum, assume significados concretamente distintos segundo o nível social do doente. Isto não quer dizer que a doença não exista, mas sublinha um fato real que deve ser levado em consideração (...)." (Basaglia, 2001, p. 105) O gozo por meio do consumo, o espetáculo e a excitação em torno dos bens materiais parece ter redirecionado nossas paixões em torno do capital. "A primeira fase da dominação da economia sobre a vida social levou, na definição de toda a realização humana, a uma evidente degradação do ser em ter." (Debord, 1997, p. 13). Essa relação fetichista com o dinheiro é uma face da alienação, da exploração, da exclusão e, acrescentaria ainda, da colonialidade do poder.

Sob a lógica mercantil e medicalizante, sabemos que os pacientes que possuem valor econômico, especialmente para a psiquiatria e para psicologia clínica, tornam-se consumidores de tratamentos, terapias e medicamentos, são responsabilizados individualmente pelas suas questões, eximindo as famílias, os profissionais, as autoridades, os governantes e os formuladores de políticas. Basaglia (2001) afirma inclusive uma diferença entre o internamento "particular" e o hospital psiquiátrico. $\mathrm{Na}$ primeira instituição o paciente nem sempre tem sua vida interrompida, pois, assim que é superado o período crítico, pode ser facilmente reinserido na sociedade. Já na experiência verdadeiramente manicomial, o efeito é des-historificante, destruidor, institucionalizante e não deixa outras alternativas. 
Que valor técnico ou científico pode ter o diagnóstico clínico com o qual foi definido no momento do internamento? É possível falar de um diagnóstico clínico objetivo, decorrente de dados científicos concretos? Ou, antes, trata-se de uma simples etiqueta que, por trás da aparência de um julgamento técnicoespecializado, esconde, mais ou menos veladamente, um significado mais profundo: o da discriminação? Um esquizofrênico rico internado numa clínica particular terá um diagnóstico inteiramente distinto do de um esquizofrênico pobre, internado à força num hospital psiquiátrico público. (...) Não seria mais adequado concluir que estes doentes, devido ao fato de serem sócioeconomicamente insignificantes, são vítimas de uma violência original (a violência de nosso sistema social), que os joga para fora da produção, à margem da vida em sociedade, confinando-os nos limites dos muros do hospital? (Basaglia, 2001, p.108)

A partir desse trecho, reconhecemos uma dupla exclusão: o sujeito é excluído por não responder de acordo com a normalidade socialmente estabelecida e a falta de produtividade economicamente esperada. A consequência dessa combinação violenta é uma cidadania alienada em que só se considera sujeito de direito o sujeito de dinheiro. Sendo assim, não há como considerar a cidadania como instrumento e finalidade do processo de trabalho na reforma psiquiátrica sem antes refletirmos sobre essas questões sociais. Não há como pensar possibilidades de reinserção social ou de protagonismo se continuarmos a oferecer uma cidadania tutelada (Oliveira \& Alessi, 2005) aos cidadãos que estão em sofrimento.

Uso o termo cidadania alienada para referir-me a um tipo de cidadania que privilegia poucos, que reconhece os direitos civis, políticos e sociais apenas daqueles que atendem todas as condições normativas de reconhecibilidade de nosso tempo. A frase repetida por alguns grupos sociais minoritários "direitos humanos são para humanos direitos" descreve bem esse raciocínio excludente. É assim que a cidadania aliena-se, quando deixa de ser de todos e para todos e torna-se propriedade de uma classe, ou ainda, quando abandona seu potencial democratizador e torna-se outro meio de exercer a violência através da sua seletividade. A cidadania alienada é herança da modernidade, é a força opressora que exclui a multiplicidade, a heterogeneidade, a hibridez das formas de vida. Sua força colonizadora cumpre o papel de apagar todas as alteridades desviantes assumindo uma mentalidade manicomial que produz um aprisionamento de toda a sociedade.

Essa cidadania construída para atender ao poder disciplinar não está mais centrada unicamente no Estado, mas capilarizada em nossas práticas, instituições e 
saberes. Está ainda intimamente relacionada com a noção espetáculo que é ao mesmo tempo parte da sociedade, a própria sociedade e seu instrumento de unificação. Em seu capítulo intitulado A separação consolidada, Debord (1997) afirma que essa característica unificadora é a própria linguagem oficial da separação generalizada. "O sistema econômico fundado no isolamento é a produção circular do isolamento. $\mathrm{O}$ isolamento fundamenta a técnica, e, em retorno, o processo técnico isola." Se a própria fabricação industrial é individualizada e alienante, os bens selecionados pelo sistema espetacular, do automável à televisão, também reforçam as condições de isolamento. De um espaço fechado a outro, da fábrica ao hospital, da família à escola, sem dúvida, essas práticas de vida influenciam nossa consciência de cidadania. A cidadania alienada alimenta a discriminação, o preconceito, a exclusão e a violência, ela é o próprio produto da intersecção da colonialidade, da modernidade e da manicomialidade.

Há uma ligação evidente entre política mercantil e a polícia do internamento, no entanto, conforme aponta Foucault (1978), nos muros do internamento não há apenas a pobreza e a loucura. Não podemos supor que todo o sentido do internamento se esgota numa finalidade social de eliminar de um grupo seus elementos heterogêneos. A própria loucura não teve uma identidade imóvel ao longo da história, ela foi ignorada durante séculos, foi obscuramente apreendida durante a era clássica como desorganização da família, desordem social, perigo para o Estado e, posteriormente, foi concebida pela consciência médica como doença. Mas é notável perceber que os internos do século XVIII reconheciam-se num mesmo gesto da segregação o personagem contemporâneo do a-social. Ao analisar esse esquema de exclusões superpostas, Foucault (1978) revela a importância de estudar a arqueologia dessa alienação, buscando analisar como um mesmo golpe de segregação transformou perfis costumeiros em sombras, sem familiaridade ou semelhança com aquilo que o homem clássico reconhecia como sua própria imagem.

Os leprosos não foram caçados a fim de impedir o contágio; por volta de 1657 a centésima parte da população de Paris não foi internada a fim de que a cidade se livrasse dos "a-sociais". Esse gesto tinha, sem dúvida, outro alcance: ele não isolava estranhos desconhecidos, durante muito tempo evitados por hábito; criava-os, alterando rostos familiares na paisagem social a fim de fazer deles figuras bizarras que ninguém reconhecia mais. Suscitava o Estrangeiro ali mesmo onde ninguém o pressentira. Rompia a trama, desfazia familiaridades; através dele, algo no homem foi posto fora do horizonte de seu 
alcance, e indefinidamente recuado em nosso horizonte. Resumindo, pode-se dizer que esse gesto foi criador de alienação. (Foucault, 1978, p. 92)

Essa alienação ocorre no contexto imediatamente posterior à Revolução Francesa, momento em que Philippe Pinel dá início às transformações nos hospitais de Bicêtre e da Salpêtrière - asilos masculino e feminino, respectivamente, em que os loucos eram mantidos acorrentados em celas baixas e úmidas, fossem ou não perigosos. Baseado em seus métodos, o médico considerou as doenças mentais como resultado de tensões sociais e psicológicas ou de acidentes físicos, abandonando a crença de possessão demoníaca. Na substituição de um tratamento desumano para um "tratamento moral", Pinel anuncia um novo princípio universal: o isolamento.

Se num primeiro momento o louco parecia se dissipar numa apreciação geral do desatino e misturava-se com os os doentes venéreos, os devassos, os libertinos, os homossexuais num internamento geral de natureza filantrópica ou jurídico-política, com a política/polícia de internamento, essa mesma ideia de desonra abastrata sem nenhum indício de diferença, começou a tomar outras formas. Pinel atestava a necessidade de confiar os alienados a mãos estrangeiras, isolados do convívio de seus familiares. (Torre \& Amarante, 2001) Esse processo de institucionalização apoiava-se em dois argumentos básicos:

a) A noção de hospital como lugar de exame. $\mathrm{O}$ isolamento era concebido como princípio científico e como método de conhecer um fenômeno por meio de uma criação de um ambiente asséptico laboratorial, sem interferências, a fim de facilitar a observação in vitro dos objetos de investigação.

b) A noção de hospital como próprio instrumento de cura. $\mathrm{O}$ isolamento assumia uma função terapêutica na medida em que afastava todas as possíveis influências maléficas que poderiam agravar a alienação. Além disso, o afastamento servia para identificar e distinguir os indivíduos entre "mansos" ou "agitados"13, entre "melancólicos" ou "sórdidos", num tipo de lista classificável que evitaria que a diversidade na convivência pudesse agravar os quadros.

\footnotetext{
${ }^{13}$ Além das classificações baseadas em justificativas psiquiátricas, a prática do internamento foi permeada por uma lógica dual cristã: de um lado há a região do bem, que é a pobreza submissa à ordem, do outro lado o mal, insubmisso. Assim, o internamento se justifica a título de benefício e de punição conforme a valoração ética. (Foucault, 1978).
} 
Em resumo, "o isolamento é ao mesmo tempo um ato terapêutico (tratamento moral e cura), epistemológico (ato de conhecimento) e social (louco perigoso, sujeito irracional)." (Torre \& Amarante, 2001, p. 73). A noção de reeducação moral ou o tratamento moral correspondia a um processo pedagógico-disciplinar realizado no interior do hospício no qual a disciplina serviria para "dobrar o alienado à razão" e torná-lo, posteriormente, um sujeito de direitos, cidadão, pois enquanto fosse sujeito delirante, seria reduzido a objeto do alienismo.

Interessante notar que o enclausuramento devido à sua natureza supostamente terapêutica não era considerado como exclusão da cidadania, nem como uma violência ao direito do alienado, ao contrário, era concebido como inclusão ao direito a um tratamento. Surge, então, um paradoxo gritante: se a concepção de cidadania pressupõe a liberdade e a igualdade como seus atributos básicos, para o "doente mental" pressupõe o amparo social do Estado, implicando na interdição desses mesmos direitos. (Oliveira \& Alessi, 2005).

O "pai da primeira revolução psiquiátrica" é um personagem interessante a ser analisada, pois parece encarnar todas as ambiguidades do olhar médico sobre a loucura. Representado em diversos hospitais no mundo inteiro como o libertador dos loucos, Pinel não criou apenas o conceito de alienação, mas também foi um dos construtores do conceito de cidadania. Inspirado pelos modernos ideais revolucionários de sua época, ele parece ter se apoiado na própria figura do alienado como encarnação do negativo do cidadão para justificar o nascimento da instituiçãopsiquiatria. O louco, aquele dito como incapaz, perigoso para si e para os outros, não estaria mais confinado pelos muros e grades concretos e visíveis, estaria agora condenado a uma exclusão muito mais refinada e sutil, uma violência claramente espetacularizada pelo tecnicismo.

O asilo construído pelo escrúpulo de Pinel não serviu para nada e não protegeu o mundo contemporâneo contra a grande maré da loucura. Ou melhor, serviu, serviu muito bem. Se libertou o louco da desumanidade de suas correntes, acorrentou ao louco o homem e sua verdade. Com isso, o homem tem acesso a si mesmo como ser verdadeiro, mas esse ser verdadeiro só lhe é dado na forma da alienação. (Foucault, 1978, p. 575)

Assim, entre o castigo e remédio, entre gesto que pune e gesto que cura, a medicina e a moral se confundiam. O novo enclausuramento inaugurado por Pinel e o 
ideal de normatização produziu uma nova experiência do fenômeno da loucura. O conceito de alienação conferiu para o louco um lugar excluído do pacto social, retirando-o de toda a possibilidade de interlocução com sua redução ao conceito de "doente mental". A correção, o controle do tempo, a punição, a classificação de uns em relação a outros, as rotinas meticulosamente planejadas, a padronização dos indivíduos e a estrutura panotípica da instituição eram artefatos para "o espetáculo de autoridade científica". Na modernidade a loucura foi colonizada pela psiquiatria através de práticas manicomiais que inauguraram "territórios de segregação, morte e ausência de verdade". (Amarante, 1995, p. 25).

Entretanto, diante de tantos princípios teóricos e atos institucionais, nunca foi posto em questão a interferência da própria experiência da institucionalização na experiência da alienação. Em outras palavras, "o que a psiquiatria concebe como efeitos da cronicidade da natureza da doença mental não seriam efeitos largamente produzidos pela institucionalização?" (Torre \& Amarante, 2001, p. 78). A resposta, como vimos no capítulo primeiro, é que o corpo enclausurado vive uma experiência tão intensa e desorganizadora de quebra temporal e espacial do projeto existencial que poderia ser suficiente para o seu despedaçamento. Basaglia (2001) chega a conclusão que, através do efeito da hospitalização, não somente poderiam ver a doença tal como ela é, mas também produzí-la.

A degradação, a objetivação e o total aniquilamento que o caracterizam não são a pura expressão de um estado mórbido, mas antes o produto da ação destruidora de uma instituição cuja finalidade é proteger os são dos assaltos da loucura. Entretanto, uma vez despido o paciente das superestruturas e das inscrustações institucionais, percebe-se antes de ser um doente mental, ele é um homem sem poder social, econômico ou contratual: é uma mera presença negativa, forçada a ser aproblemática e acontraditória com o objetivo de mascarar o caráter contraditório de nossa sociedade. (Basaglia, 2001, p. 112)

A loucura foi alienada pela psiquiatria - e também pela psicanálise ${ }^{14}$. "'O que

\footnotetext{
14 "Freud fez deslizar na direção do médico todas as estruturas que Pinel e Tuke haviam organizado no internamento. Ele de fato libertou o doente dessa existência asilar na qual o tinham alienado seus 'libertadores'. Mas não o libertou daquilo que havia de essencial nessa existência; agrupou os poderes dela, ampliou-os ao máximo, ligando-os nas mãos do médico. Criou a situação psicanalítica, onde, por um curto-circuito genial, a alienação torna-se desalienante porque, no médico, ela se torna sujeito. $\mathrm{O}$ médico, enquanto figura alienante, continua a ser a chave da psicanálise. (...) a psicanálise não pode e não poderá ouvir as vozes do desatino, nem decifrar em si mesmos os signos do insensato." (Foucault, 1978, p. 554)
} 
se chama doença mental' é apenas loucura alienada, alienada nesta psicologia que ela própria tornou possível." (Foucault, 1975, p.61), afinal, nossa sociedade não quer reconhecer-se no conceito de doente que ela mesma persegue, negligencia ou reprime. Vale lembrar que o sentido de desvio da natureza para a doença e um status excludente atribuído ao doente são concepções datadas que possuem coerência apenas em determinado contexto já que "a doença só tem realidade e valor de doença no interior de uma cultura que a reconhece como tal. (p. 49)". Levar em conta essa afirmação é um grande passo desconstruir o paradigma científico clássico.

Para Basaglia (2000), o sujeito foi colocado entre parênteses, para então, analisarem a doença como fenômeno da natureza. Mas, e se esse processo fosse invertido? A proposta basagliana de colocar em parânteses a doença, e não o sujeito, não deve ser confundida como uma negação do sofrimento por ela causado. Trata-se de uma posição de recusa em relação ao poder psiquiatrico quanto à redução do fenômeno da loucura ou do sofrimento psíquico ao conceito de doença e a condição de estar institucionalizado. Esse ato representou uma ruptura epistemológica importante, indicando os próximos passos para por em funcionamento um dispositivo de desinstitucionalização.

\subsection{3 - Desconstrução, desinstitucionalização e desalienação}

A destruição de conceitos aprisionadores e redutores da complexidade dos fenômenos não se dará do dia para a noite. A desconstrução de todo um aparato psiquiátrico que envolve um emaranhado de relações de poder requer muita luta. Certamente percebemos em nossas práticas que ainda estamos contaminados pelo modelo ideológico da velha psiquiatria, especialmente no campo da psicologia.

Durante toda a primeira metade do século $\mathrm{XX}$, diversas matrizes teóricas na psicologia foram surgindo com diferentes enfoques: estudo dos processos sensoriais cognitivos, criação de testes, avaliação das capacidades e traços dos indivíduos, entre outros. Todos participavam da representação dominante marcada por uma visão individualista de seu objeto de estudo. Esse cenário só começou a mudar após as repercussões das duas guerras mundiais que trouxeram mudanças radicais nos 
sistemas de comunicação, nos avanços de outras ciências e, para a psicologia, um olhar mais atento aos aspectos sociais (González, 2002, 2003).

As novas questões colocadas nesse novo cenário histórico mundial também repercutiu em movimentos reformista na psiquiatria que buscavam superar a tradição pineliana. As experiências de reformas aconteceram em vários países e podem ser didaticamente organizadas a partir de um mapeamento cronológico. Segundo Amarante (2013) podemos dividir em dois grupos mais um: a psicoterapia institucional e as comunidades terapêuticas, reformas ainda apegadas à dimensão asilar; a psiquiatria de setor e psiquiatria preventiva, que representaram algum avanço efetivo em direção a um ambiente comunitário, extra-hospitalar; e a antipsiquiatria e as revoluções de Basaglia que marcaram uma ruptura com os movimentos anteriores.

Em resumo, pode-se dizer que o primeiro grupo reagia ao deteriorante espetáculo asilar propondo mudanças na própria instituição, mantendo a estrutura hospitalocêntrica. A comunidade terapêutica e a psicoterapia institucional acreditavam que qualificar a psiquiatria seria suficiente para torná-la um espaço terapêutico. Foi nesse contexto em que surgiu a "terapia ativa", mais conhecida hoje como terapia ocupacional, em que observou-se os efeitos benéficos do trabalho dos pacientes (Amarante, 1995, 2013). Uma "descoberta" coveniente que surgiu na década de 1920, a partir da necessidade de mão de obra para a construção de um hospital.

Assim, reavivada a ideia de que o trabalho recolocaria o sujeito na sociabilidade de produção, surge outra proposta nesse mesmo período: a integração dos pacientes em sistemas grupais. A criação de um novo complexo hospitalar gerido comunitariamente apresentava algumas limitações, conforme aponta Basaglia (2001). O princípio da "terapêutica ativa" buscava resgatar a função primordial da casa dos alienados: a cura. Se a instituição psiquiátrica tornou-se um lugar de descaso, de violência e repressão é porque havia se desviado de sua finalidade "terapêutica". Sendo assim, a comunidade terapêutica e a psicoterapia insitucional fabricavam uma pedagogia de sociabilidade e de artificialismos, uma microssociedade em que se pretendia regular todos os excessos passionais da loucura. Entretanto, instituir uma outra realidade, não compartilhada pela sociedade mais ampla, era negar a raiz da exclusão. (Amarante, 1995, 2013; Basaglia, 2001) 
O segundo grupo, reconhecendo o esgotamento desse modelo, apostava numa desmontagem asilar gradual, em que os serviços assistenciais iriam pouco a pouco diminuindo a importância e a necessidade do hospital psiquiátrico. A psiquiatria de setor a fim de evitar o isolamento e a segregação propunha uma terapia in situ levando em consideração a área geográfica e social do sujeito. Ainda que a possibilidade de assistência na própria comunidade se mostrasse terapêutica, a prática dessa experiência não alcançou os resultados esperados em função da resistência de setores mais conservadores. (Amarante, 1995, 2013)

Sobre o projeto de psiquiatria preventiva podemos afirmar que teve uma considerável contribuição na prevenção primária, secundária e terciária que visavam não mais a cura, mas a redução dos transtornos mentais numa comunidade, tratandoos precocemente na busca da readaptação do paciente à vida social. Além de incluir as contribuições da psicologia e da psicologia e sair do terreno específico da psiquiatria, esse novo modelo psiquiátrico compreendia a saúde mental em termos de coletividade, composta por equipes comunitárias, pela comunidade, numa perspectiva biopsicossocial. As propostas inspiradas pelo preventivismo deram os primeiros sinais de desinstitucionalização com a instauração de vários modelos assistenciais. Para alguns, apesar da implantação dos hospitais-dia, leitos em hospitais gerais, lares abrigados e demais políticas de desospitalização, a psiquiatria preventiva não deixava de ser um novo projeto de medicalização da ordem social e propagação dos preceitos médicos-psiquiátricos. (Amarante, 1995, 2013)

A psiquiatria toma então, explicitamente, uma feição ambígua. (...) Como Prevenção, ela se pretende uma disciplina articulada à psiquiatria geral, e mesmo à Medicina, pelo viés da Saúde Pública, mas é, ao mesmo tempo, uma produção do sistema estatal que erige alguma coisa como ideal normativo de saúde psíquica. Pocura-se costurar os termos desta disparidade denominando a Psiquiatria Preventiva como a realização dos anseios da "Comunidade". (Birman \& Costa, 1994, p. 54)

A visão polarizada entre saúde e doença, entre a adapatação e desadaptação social parte do pressuposto de que a comunidade corresponde a um sistema homeostático, de interações normatizadas, com características naturalmente cooperativas e espontaneamente terapêuticas. A psiquiatria torna-se, então, um instrumento reequilibrador das tensões "comunitárias" e o "psiquiatra torna-se uma espécie de funcionário burocrático do equilíbrio comunitário" (Birman \& Costa, 1994, 
p. 56). O risco se instala justamente quando a psiquiatrização da vida se banaliza em nome da promoção da saúde mental, no enquadramento do perfil do Homem Normal.

Já a concepção da antipsiquiatria - no tom encolerizado de Cooper (1974) chegou para inverter as normas do jogo psiquiátrico e subverter a ordem social burguesa repressiva. Ela veio para questionar esse processo de normalização baseado "no desejo de uma vida uniforme, progressivamente facilitada, segura, "feliz" e agradável que, sem dúvida, é uma espécie de morte" (p. 76). Para não deixar o paciente ser conduzido "a condição lamentável e desamparada em que o próprio psiquiatra caiu" (p. 71), a antipsiquiatria propõe uma renuncia a esses dispositivos normativos e, para tanto, deveria estar em constante revolução. Para romper com a lógica do "bem-adestrado-para-curar" se fazia imprescindível a substituição do papel unilateral do psiquiatra versus paciente, abandonando toda a estrutura infantilizante e paternalista para estabelecer uma relação de reciprocidade.

A antipsiquiatria, essa antítese à teoria psiquiátrica, foi sem dúvida um marco teórico-conceitual ${ }^{15}$, motivo que fez Amarante (2013) preferir separá-la das demais reformas, conferindo-lhe o devido destaque à sua inovação. Nessa perspectiva, a noção de desinstitucionalização distanciava-se da concepção norte-americana com o foco apenas desospitalizante, para adquirir características muito mais complexas. "Agora a doença, bem fora de parênteses, se revela como o lugar geométrico das incrustações judicirotrárias, diagnósticas e científicas aplicadas sobretudo, e sem contradição, às classes subalternas (Rotelli, 1990, p. 91)

Tais transformações foram influenciadas pela psiquiatria democrática protagonizada por Franco Basaglia. Nos anos de 1960, o psiquiatra italiano, juntamente com outros jovens psiquiatras, se propuseram a reformar o hospital psiquiátrico, em Gorizia. Após sua impressão de choque de sua primeira visita ao local - uma visão tal qual um campo de concentração - buscou transformar o tratamento e a reabilitação dos internos inspirando-se na experiências da comunidade terapêutica e na psicoterapia institucional. Embora criticasse essas propostas, inglesa e francesa, o princípio de democratização das relações e a ideia de territorialidade

\footnotetext{
${ }^{15}$ Amarante (2013) aponta que a ruptura radical com o saber psiquiátrico moderno acabou deslizando suas explicações para uma teoria da lógica das comunicações, uma explicação causal da esquizofrênia baseada nos problemas de comunicação entre as pessoas.
} 
foram conservadas. Com o tempo, percebeu que não seria simples reverter os efeitos da "serpente" por meio de medidas administrativas ou de humanização, essas estratégias seriam apenas de caráter provisório e intermediário à desmontagem da estrutura manicomial. (Amarante, 1995)

Na década seguinte, essa mesma equipe partiu para Trieste, onde começaram uma transformação radical da psiquiatria contemporânea. Os serviços substitutivos regionalizados que atuavam no território reconstruindo as formas como as sociedades lidavam com as pessoas com sofrimento psíquico, a criação de cooperativas de trabalho, a construção de residências para ex-internos, grupos musicais e de teatro, produtora de vídeos e outras oficinas são exemplos das mudanças desse paradigma que buscava resgatar a complexidade do fenômeno reduzido pelas antigas instituições.

Para nós, o objeto sempre foi a "existência-sofrimento dos pacientes e sua relação com o corpo social. O mal obscuro da Psiquiatria está em haver constituído instituições sobre a separação de um objeto fictício - a doença - da existência global, complexa e concreta do paciente e do corpo da sociedade. (...) Negação da instituição, bem mais que o desmantelamento do manicômio, foi e é, a desmontagem desta causalidade linear e a reconstrução de uma concatenação de possibilidade-probabilidade: como toda ciência moderna nos ensina diante de objetos complexos. (Rotelli, 1990, p. 89)

Se o manicômio é o locus do saber psiquiátrico e a metáfora concreta da exclusão, entendo que o desejo de desmantelamento do manicômio é a própria negação da instituição. Para além da extinção de organizações hospilares ou manicomiais, a desinstitucionalização é "a desconstrução de saberes/práticas/ discursos comprometidos com uma objetivação da loucura e sua redução à doença." (Amarante, 2013, p. 49). Essa desconstrução pressupõe uma superação de todos os paradigmas clássicos apoiados aos discursos de verdade e neutralidade nas ciências que concebiam a experiência psíquica diversa como sinônimo de erro.

Abalar os pilares da violência entre saber e poder e reconhecer a incapacidade da psiquiatria em curar o seu objeto de intervenção é o início do fim da manicomialidade. É a recusa à tecnificação e a relação de tutela instaurada pela psiquiatria e o reconhecimento existência-sofrimento do sujeito em relação com o seu contexto social (Amarante, 2013; Rotelli, 1990). Superar o modelo manicomial requer uma nova invenção da saúde, não basta apenas uma simples reforma das tecnologias antigas colocando outras novas no lugar, é necessário recomeçar tudo. 
Onde há relação tutelar, deve ser estabelecida a relação contratual; onde há interferência compulsória, entra a não interferência para fazer emergir a experiência em vez de encerrá-la; as hierarquias sociais transformam-se em sociabilidades horizontalizadas; a opressão abre-se para a interlocução; a passividade do corpo institucional encontra a criatividade do corpo próprio/pessoal/vivido; a exclusão reconhece um novo lugar para a loucura no mundo e um novo tipo de subjetividade que possa exprimir o devir-louco livremente. Toda essa desconstrução aponta para novas relações que se dão por meio da transformação institucional em que o sujeito marcado pelo exame clínico e pelo diagnóstico psiquiátrico percorre um trajeto de desenclausuramento para afirmar-se como usuário do sistema de saúde que luta por sua própria cidadania. (Torre \& Amarante, 2001). Luta sim, porque estamos nos referindo a um modo político de enfrentamento:

a luta contra as atuais estruturas psiquiátricas enquanto repressivo-custodiais; a luta contra as estruturas psiquiátricas, ainda que reformadas, mas lugar de institucionalização da doença; a luta contra a institucionalização do sofrimento através da doença; a luta contra o sofrimento como necessidade do mundo do capital e da sociedade de troca, isto é, do universo de não escolha, onde o sofrimento vem transformado em algo mercantilizável. (Amarante, 1994, p. 66)

A luta pela desinstitucionalização não se configura apenas uma reestruturação da assistência psiquiátrica, mas de todo um projeto civilizatório que nos convida a repensar a relação que estabelecemos com o sofrimento e com a diferença em nossa sociedade. Desse modo, a descontrução do manicômio extravasa seu contexto específico, já que também diz respeito às manicomialidades presentes nas demais instituições que reproduzem modelos abstratos e idealizados do ser humano. Por isso, devemos desinstitucionalizar não apenas os manicômios, mas também as famílias, as universidades, as escolas, as ciências, as mídias, as políticas, as identidades e todos os meios de opressão que se articulam a partir da mesma ordem disciplinar hegemônica. "A desinstitucionalização atinge então seu objetivo mais amplo de questionamento das instituições e subjetividades capitalísticas: é a desconstrução como transformação cultural" (Torre \& Amarante, 2001, p. 83)

A máquina institucional que pretendia fabricar indivíduos homogeneizados ou facilmente classificáveis nas categorias psiquiátricas tornou-se obsoleta já que não tem competência para a produção de subjetividades. Assim, não cabe mais falar de 
um ato terapêutico-médico sobre a doença em que as estratégias são previamente engessadas às rotinas burocráticas, mas sim em formas de organização coletiva carregadas de sentido, de movimento, voltadas para a produção de vida e de novas potencialidades. Pode-se dizer que o ponto chave do caminho da desinstitucionalização é criar um novo tipo de relação com a loucura e um novo lugar social para o sujeito em sofrimento psíquico. (Torre \& Amarante, 2001).

Tal como aponta Rotelli (1990), o trabalho terapêutico é o próprio trabalho de desinstitucionalização, de reconstrução das pessoas enquanto atores sociais, de descarte de todas as máscaras de uma identidade estereotipada e estigmatizada colocada sobreposta ao semblante do sofrimento. Nessa perspectiva, se tratar significa transformar os modos de viver,

então a terapeuticidade é a intencionalidade dos serviços que são intermediários materiais, capazes de colocar em movimento trocas sociais bloqueadas, de recolher e valorizar deslocando-os, desinstitucionalizando-os por paradoxo, os sintomas, os símbolos, os sentidos plurais do paciente. (p. 93)

As trocas plurais fazem parte do cotidiano da cidade. "Não existe para mim um centro de saúde mental mais bonito do que um mercado no Senegal ou em Marrocos." (Rotelli, 1990, p. 92). Ali as pessoas se olham, trabalham, se misturam diferentes classes num mesmo turbilhonamento, como qualquer bom mercado, os corpos circulam sem catracas, cada qual ao seu ritmo. É justamente o tom da participação singularizada de cada indíviduo que dá harmonia a essa sofisticada música urbana. Acredito que um dos caminhos possíveis da desinstitucionalização seja a multiplicação de espaços em que a coletividade saiba expressar seu acolhimento às singularidades, sem restrições. A redefinição do lugar do sujeito da diferença é o princípio da desalienação da nossa sociedade.

Infelizmente o que observamos é que o conceito da desinstitucionalização ainda não é compreendido com clareza no campo da saúde, repercutindo numa cidadania alienada. Enquanto essa incompreensão permanecer, corremos o risco de deixar os mecanismos do dispositivo psiquiátrico no controle. (Torre \& Amarante, 2001) Sair do manicômio é um passo mais fácil, difícil é o manicômio sair de nós. 
2.4 - A reforma psiquiátrica brasileira e a presença da manicomialidade

Conforme vimos, Trieste foi um verdadeiro laboratório de desinstitucionalização, o intercâmbio de papéis era experimentado o tempo todo entre artistas, artesãos, loucos e sãos; novas práticas surgiam a cada instante e assim, a produção cultural borbulhava, revelando um movimento muito além da proposição inicial da doença entre parênteses - conforme reconheceu o movimento numa análise auto-crítica. Vale lembrar que a experiência italiana demorou muito para acontecer, mas esse atraso foi o que fez com que a Itália pudesse aprender com os erros e acertos das reformas psiquiátricas dos outros países. (Amarante, 1995). Esse movimento denunciador e de reformulação das práticas manicomiais em torno do mundo moderno foi marcado por singularidades próprias de cada território, mas, em alguma medida, existem marcadores comuns a essas reformas.

Em vez de apontar as semelhanças da implementação e desenvolvimento da reforma psiquiátrica nos diferentes contextos, interessa-me conhecer as dificuldades enfrentadas no cenário da pós-desinstitucionalização. A ebulição dos movimentos que lutavam pelo fim das instituições asilares por vezes recebeu um balde de água fria quando viram que até o modelo "portas abertas" reproduzia condutas idênticas às instituições fechadas. A reforma é um campo heterogêno que age sobre diversas dimensões - clínica, política, social, cultural - (Tenório, 2002) mas todas parecem estar rodeada pelo mesmo fantasma da manicomialidade.

Se, mesmo com o desaparecimento do colonialismo permanece a colonialidade, pode-se dizer, do mesmo modo, que a extinção dos manicômios não extinguiu a presença da manicomialidade. A racionalidade carcerária está mais viva que nunca, especialmente nos debates sobre questões raciais e de saúde mental. O desejo de dominar, de subjugar, de oprimir não se encerra em um único ato de opressão, mas se repete, dia após dia no cotidiano dos serviços, com estratégias cada vez mais sutis. Os desejos de manicômio representam a pulsão vital da colonialidade, funcionando num movimento narcísico de constante afirmação da própria identidade hegemônica.

A despeito desses obstáculos, temos avançado. A influência basagliana também serviu para impulsionar o movimento reformista brasileiro a fim de construir 
uma nova maneira da sociedade se relacionar com a loucura, garantindo o status de cidadão ao usuário de saúde mental. Entretanto, os resquícios do colonialismo e da manicomialidade tornam essa mudança mais desafiadora no território nacional.

\subsection{1 - As especificidades da reforma psiquiátrica brasileira}

Foi com a vinda da Família Real Portuguesa, em 1808, que surgiram os primeiros asilos que funcionavam como depósitos de pessoas a fim de atender à lógica compatível ao desenvolvimento mercantil e as novas políticas do século XIX. Em 1852 vimos a inauguração do primeiro hospício no país que recebeu o nome do imperador D. Pedro II. Localizado na Praia Vermelha, no Rio de Janeiro, o manicômio encontrava-se num local afastado do centro da cidade sob o pretexto de proporcionar calma aos pacientes num lugar espaçoso e tranquilo. Com capacidade de receber 350 pacientes, a instituição atingiu a lotação com pouco mais de um ano de abertura. Esse foi o prenúncio do sequestro da cidadania que se perpetuou nos anos seguintes. (Mesquita et al., 2010)

Nos anos de 1960, com a criação do Instituto Nacional de Previdência Social (INPS), resultado da unificação dos institutos de pensões e de aposentadoria, o Estado passa a financiar a indústria de enfrentamento à loucura ao comprar os serviços psiquiátricos do setor privado. No entanto, o caráter privatista da política de saúde do governo central e a ineficiência da assistência pública em saúde geram insatisfação popular. A precariedade no atendimento psiquiátrico e as inúmeras denúncias do abandono, da violência e dos maus-tratos a que eram submetidos os pacientes internados, dão o pontapé para o período germinativo da reforma psiquiátrica no Brasil - não por acaso acontece num período de intensa redemocratização do país. Até o momento a crítica popular se restrigia apenas os excessos das práticas asilares e não aos seus pressupostos. (Mesquita et al., 2010)

Nesse período cresce o poder de corrupção no circuito de assistência psiquiátrica, os custos globais da psiquiatria chegavam a níveis desproporcionais em comparação às outras necessidades sanitárias, os hospitais conveniados incentivavam a cronicidade visando o aumento dos lucros. Para os profissionais, baixos salários; para os internos a sobra. Isso provocou "um movimento de protesto que se consolidou em torno de um desejo existente no País, por si só complexo, de cidadania e justiça 
social" (Amarante, 1995, p. 13)

No bojo de toda a movimentação político-social, no Rio de Janeiro, em 1978, surge o movimento dos trabalhadores da Divisão Nacional de Saúde Mental (DINSAM) que denuncia as práticas violentas de alguns hospitais psiquiátricos num tom crítico à conjuntura do subsistema nacional de saúde mental e à estrutura do saber psiquiátrico - marco que ficou conhecido como "crise da DINSAM". É nesse contexto que surge pequenos núcleos estaduais, especialmente em São Paulo, Rio de Janeiro e Minas Gerais, constituindo o Movimento de Trabalhadores em Saúde Mental (MTSM). Esse movimento de combate ao Estado autoritário, seu discurso humanitário e suas reivindicações trabalhistas tiveram uma grande repercussão no projeto de uma sociedade antimanicomial. (Tenório, 2002)

Enquanto isso, na Itália, em 13 de maio do mesmo ano, foi instituída a Lei 180, Lei de Basaglia, que, articulada com a lei italiana da Reforma Sanitária, garantia o direito ao tratamento psiquiátrico qualificado por meio de uma rede de cuidados em saúde mental. Tais normas legislativas tiveram um papel fundamental para a reestruturação da atenção psiquiátrica, um modelo que inspirou o Brasil a um objetivo semelhante, como por exemplo, o Projeto de Lei n. 3657 do deputado federal Paulo Delgado, do Partido dos Trabalhadores, em 1989. (Tenório, 2002; Mesquita et al., 2010)

Tal como na Itália, o movimento de reforma sanitária teve influência constitutiva no movimento de reforma psiquiátrica, já que a má assistência à saúde não era exclusividade da psiquiatria. Durante os anos de 1980, houve muita discussão sobre os direitos dos pacientes, focada na ampliação do direito à saúde como questão político-social. (Tenório, 2002) Desse modo, percebe-se que o debate sobre cidadania na sua relação com a loucura era limitado às macro-mudanças legislativas, jurídicas e administrativas. "O movimento de Reforma Psiquiátrica, na época, admitia a cidadania como relacionada ao resgate da dívida social para com os loucos." (Mesquita et al., 2010, p. 195) Ainda assim, a busca dos movimentos populares em garantir nos textos legais e oficiais não foram em vão, elas prepararam o terreno para o amadurecimento de uma outra perspectiva e para a operacionalização de novas práticas terapêuticas. 
Pode-se dizer que a apliação do sentido político-conceitual da proposta antimanicomial nasceu na década de 1980 com a concretização de várias eventos importantes. O primeiro deles foi a Conferência Nacional de Saúde Mental (I CNSM), que ocorreu em 1987, e o posterior II Encontro Nacional dos Trabalhadores em Saúde Mental que marcaram o fim da trajetória sanitarista e o início da desinstitucionalização. Surge em Bauru, São Paulo, o Movimento de Luta Antimanicomial com um novo lema: Por uma sociedade sem manicômios.

Estabelece um novo horizonte de ação: não apenas as macrorreformas, mas a preocupação com o ato de saúde, que envolve profissional e cliente; não apenas as instituições psiquiátricas, mas a cultura, o cotidiano, as mentalidades. E incorpora novos aliados: entre eles, os usuários e seus familiares, que, seja na relação direta com os cuidadores, seja através de suas organizações, passam a ser verdadeiros agentes críticos e impulsionadores do processo. (Tenório, 2002, p. 35)

Esse movimento libertário e social indicou novos caminhos, novos dispositivos e novas tecnologias de cuidado, articulando loucura e cultura. Sem dúvidas essa foi uma das estratégias para se combater a exclusão e favorecer a da tolerância e respeito pela diferença. Nesse sentido, não bastava defender os direitos civis, sociais e políticos daqueles que sofrem, era preciso promover uma reconfiguração profunda na sociedade e no modo como ela se relaciona com a alteridade.

Essa reconfiguração molda de maneira diferente nossa própria experiência subjetiva, na medida em que este Outro se expressa não apenas na experiência do louco, mas também nas fímbrias, desvãos e mistérios que habitam a experiência de todos nós. Esta perspectiva teórica, portanto, amplia o alcance ético e político contido nas propostas da Reforma, uma vez que seu horizonte ultrapassa os limites da simples assimilação do louco à realidade social compartilhada, projetando uma transformação profunda de nossas concepções e relações com a subjetividade. (Bezerra Jr, 2007, p. 250)

A partir dessas considerações, o terceiro momento da Reforma Psiquiátrica que compreendia um esforço de desinstitucionalização suscitou uma nova concepção de cidadania vinculada não apenas a atributo formal, mas a um projeto aberto, coletivo que deveria ser construído cotidianamente. Como aponta Oliveira e Alessi (2005), nesse período percebeu-se que "o mais importante não era reivindicar os direitos de cidadania, mas construir essa cidadania" (p. 196). Assim, pode-se dizer que a Reforma Psiquiátrica teve um papel fundamental no processo de construção da 
cidadania brasileira.

Conforme documento apresentado à Conferência Regional de Reforma dos Serviços de Saúde Mental: 15 anos depois de Caracas, o Movimento pela Reforma Psiquiátrica pode ser dividido em três fases: a primeira, entre 1978 a 1991, marcada por uma crítica ao modelo hospitalocêntrico; a segunda de 1992 a 2000, determinada não apenas em reduzir os leitos psiquiáricos, mas em qualificar, expandir e fortalecer toda a rede extra-hospitalar; e a terceira, de 2001 a 2005, que compreendia a reforma após a lei nacional. Hoje, fala-se de uma política nacional voltada para a desinstitucionalização a partir de um modelo descentralizado e de base comunitária. (Brasil, 2005)

Durante esses anos, alguns eventos merecem ser destacados, por exemplo, o surgimento do primeiro CAPS no Brasil, na cidade de São Paulo, em 1987; uma intervenção com repercussão nacional em um hospital psiquiátrico, a Casa de Saúde Anchieta, local conhecido pelos maus-tratos e mortes de pacientes; e a experiência do município de Santos. Essas foram ações concretas que demonstraram que a desinstitucionalização é possível e exequível. (Brasil, 2005)

Dentre as mudanças legislativas que deram base para alcançar esses avanços, está a Lei Federal 10.216/2001 que redireciona o cuidado em saúde mental, estabelece a extinção progressiva dos manicômios no país e regulamenta os direitos da pessoa com transtornos mentais. Foram 12 anos de tramitação no Congresso Nacional para que essa lei fosse aprovada e, é claro, ela foi alvo de muitas críticas, principalmente por parte dos proprietários de hospitais e clínicas privadas conveniadas ao SUS. Vale lembrar que o próprio percurso para a aprovação desse texto não foi fácil. Em janeiro de 2000, o projeto original teve um substitutivo muito mais tímido quanto à substituição asilar, um texto incoerente e ambíguo, pois autorizava explicitamente a construção de novos hospitais e a contratação de novos leitos em hospitais psiquiátricos nas regiões onde não exista estrutura assistencial. (Tenório, 2002)

Felizmente, a aprovação da lei representou um ganho, um novo impulso aos serviços desinstitucionalizantes que já apontavam na época, tal como os Serviços Residenciais Terapêuticos (SRTs) e o Programa de Volta para Casa (Lei Federal 10.708/2003). A intensificação do debate e a popularização da causa da reforma fez a 
luta avançar. (Tenório, 2002) Os demais serviços que surgiram para compor a rede de atenção psicossocial foram igualmente importantes, são eles: Núcleo de Atenção Psico-social (NAPS); Centro de Atendimento Psico-social (CAPs I, CAPs II, CAPs III, CAPsi, CAPsad); Centro de Atenção Diária (CADs); Hospitais Dias (HDs); Centros de Convivência e Cultura. Os CAPS, serviços substitutivos (e não complementares) aos hospitais psiquiátricos, assumiriam um papel estratégico na articulação da rede comunitária de cuidados, funcionando como porta de entrada para os demais serviços e atendendo aos critérios pulacionais e as demandas dos municípios. (Brasil, 2005)

Esses novos dispositivos para a redução dos leitos psiquiátricos e ampliação da rede extra-hospitalar buscam acolher as pessoas em sofrimento, estimular sua integração social e familiar e incentivar sua busca de autonomia. Não cabe nesse trabalho, contudo, especificar a função de cada um desses serviços em seus diferentes níveis, afinal, isso já está muito bem descrito nos diversos textos que compõem a Política Nacional de Saúde Mental ${ }^{16}$. Com toda a articulação das leis e portarias no sentido de direcionar recursos e atenção para as ações de cada área geográfica, interessa-me perceber quais são as dificuldades da implementação dessa rede no território - entendido como o conjunto de referências sócio-culturais e econômicas que constituem o sujeito no mundo.

Podemos tomar como exemplo a primeira Residência Terapêutica de Barbacena, criada em novembro de 2000 e ocupada por cinco pacientes do sexo feminino, provenientes dos hospitais conveniados ao SUS. Naquele ano, havia cinco hospitais psiquiátricos na cidade - um público e quatro conveniados - abrigando cerca de 1.500 pacientes. Esse processo foi realizado sem preparação prévia das pacientes, o que gerou problemas iniciais de adaptação, pois as moradoras não se conheciam,

\footnotetext{
${ }^{16}$ Redução dos leitos psiquiátricos (PT 251/2002 e PT 52 e 53/2004), ampliação dos serviços substitutivos, (PT 336/2002), Residências Terapêuticas (PT 106/2000 e PT 1.200/2000), programa "De volta para casa"(PT 2077/2003), a normatização dos serviços substitutivos no campo da assistência (PT 224/92), Lei 10.708/2003, Lei 10.216/2001. (Brasil, 2005). Bem como o própria própria Declaração de Caracas, documento que marca as reformas na atenção à saúde mental nas Américas. Além da Conferência de Caracas, há um outro documento político adotado pela Organização das Nações Unidas: "Princípios para a proteção de pessoas com problemas mentais e para a melhoria das Assistência à Saúde Mental", que visa assegurar os direitos da pessoa portadora de sofrimento mental, tratando-a, dessa forma, como cidadã.
} 
possuíam hábitos distintos e eram originárias de diferentes serviços hospitalares.

Já era previsto que a saída dos pacientes do hospital não seria capaz de garantir uma reinserção social bem-sucedida diante de tantos impasses como a falta de intensivo acompanhamento dos pacientes; a ausência de equipes capacitadas para intervenção em crise; o déficit de habilidades sociais e cotidianas decorrentes do longo enclausuramente; o abuso de substâncias ou interrupção da medicação o envolvimento em pequenos delitos e as reospitalizações frequentes. Nenhum desses problemas foge ao óbvio hiato entre a política e o cotidiano dos serviços de saúde, o mesmo abismo que vimos entre as classes sociais no Brasil.

Essas dificuldades do convívio entre os usuários (que existe em qualquer residência habitada) e o frequente descumprimento das leis já são desafios conhecidos, mas o que vemos para além do óbvio? A cartilha "Residências Terapêuticas: o que são para que servem" publicada pelo Ministério da Saúde, ao descrever o cotidiano nos SRTs aponta:

Ponto de vista dos usuários: deve-se considerar eventuais inseguranças em deixar o hospital, via de regra uma referência segura para eles. Há que se montar estratégias que permitam aos futuros moradores estabelecerem vínculos de confiança com os profissionais e com a proposta. (Brasil, 2004, p. $11)$.

Num primeiro momento, essas inseguranças parecem estar relacionadas tão somente aos vínculos afetivos e aos projetos perdidos daqueles que passaram por um intenso processo de institucionalização. Mas atenção, o medo não se concentra apenas no passado particular de cada sujeito, pois, ainda que este esteja fragmentado, seus sentimentos estão vinculados a um projeto existencial que se direciona para um desafio ainda maior: o de desinstitucionalizar a própria sociedade. Se o exercício subjetivo de reconfigurar o passado não é uma tarefa fácil para ninguém, certamente as histórias marcadas pelo sofrimento serão as mais necessitadas de um amparo psicossocial. Nesse momento de maior fragilidade, a sociedade vira as costas a essas pessoas e, para não ver-se tão de perto, deixa de reconhê-las como pessoas. Depois da traição do abandono, como é possível confiar novamente?

Conseguir construir um vínculo de confiança, apesar de todas essas memórias, é uma dádiva. Reconheço esse gesto como a expressão máxima de esperança, um 
movimento de ampliação das possibilidades que exige do sujeito uma força desumana para conseguir superar todas as desumanidades vividas. A construção desse vínculo entre usuários de saúde mental e profissionais é a parte fundamental do processo de desinstitucionalização, é a base do desenvolvimento da autonomia e da liberdade do sujeito. Logo, vemos que nossas dificuldades estão localizadas exatamente aí.

Ainda que considerássemos que a relação entre usuários e profissionais fosse satisfatória, há um outro fator preocupante, a sociedade. Seguindo o caso da primeira RT de Barbacena, foi diagnosticada uma forte resistência inicial da comunidade em razão da falta de informação sobre o que seriam as RTs e ao preconceito e medo em relação à "doença mental". Dessa forma, abrir as portas dos infernos manicomiais parece causar mais insegurança a quem? Por que há tanto medo em reconhecer a contra-natureza como parte essencial de nossa natureza? A despeito de todas as barreiras da reinserção em função do comprometimento da vida social, o sentimento de insegurança que acompanha a saída dos hospitais psiquiátricos atribuído à fala dos usuários de saúde mental parece ter sido mencionado de maneira bastante inapropriada. Desresponsabilizar os profissionais pela sua incapacidade de construir vínculo de cooperação e de co-responsabilidade com a comunidade, desresponsabilizar a sociedade pela sua incapacidade de acolher a diferença e responsabilizar apenas o usuário pelos seus medos é o caminho mais curto e o mais danoso.

Essa primeira experiência de RT fez com que as segunda e terceira casas foram formadas, respectivamente, em agosto de 2001 e junho de 2003, tivessem um preparo mais cuidadoso. Procurou-se identificar previamente as características e o desejo do grupo que seria desospitalizado e adotar como um dos critérios de seleção dos cuidadores não ter experiência anterior de trabalho em hospital psiquiátrico a fim de evitar vícios manicomiais. O grande prêmio da substituição da vida coletivizada das instituições totais pela vida coletiva na comunidade está em relatos como esse: "Uma casa... é o habitar da cidade. É você poder habitar a cidade, tendo um lugar para voltar... para voltar no fim do dia. Eu habito esta cidade!" (Brasil, 2004, p. 13)

Conforme apontado pela Organização Mundial da Saúde (OMS) há de se considerar os avanços no quadro de mudanças da reforma psiquiátrica, mas nossas preocupações, contudo, não desaparecem enquanto há riscos de que os hospitais 
psiquiátricos continuem a desenvolver o papel de "controlador da periculosidade e da cronicidade" psiquiátrica. Aspiramos por um modelo de serviços de saúde mental integrado, com medidas preventivas com foco na participação ativa da comunidade, para tanto, se fazem necessárias algumas intervenções objetivas - que acompanham o processo no seu crescimento - e subjetivas - que definem a propriedade do processo.

Primeiramente, as normas legislativas de reestruturação psiquiátrica aplicadas a todos os estados. Destaca-se a necessidade de uma rede alternativa ao internamento sólida e eficiente, com possibilidade de atendimento aos pacientes graves. A municipalização das ações de saúde é uma estratégia primordial para a descentralização do poder e obtenção da saúde pelas parcelas da população mais necessitadas, além de estimular a participação comunitária. A expressão ativa de usuários, familiares e comunidade são resultados desse processo. No entanto, para além de uma esteriotipada insistência da participação ativa desses grupos no projeto terapêutico antimanicomial maior, os caminhos para a produção social da saúde devem ultrapassar a própria crítica à psiquiatria tradicional. Destaco as palavras de Ernesto Venturini, diretor de Saúde Mental de Ímola (Ítalia), apresentadas no prefácio do livro Loucos pela vida (1995):

Eu penso, todavida, que os familiares e usuários devem desenvolver um papel mais incisivo que a simples representação formal, voltada para a defesa das necessidades de uma 'categoria'. O conceito de 'cidadania', por exemplo, assim prepotentemente afirmado nas instâncias inovadoras do Brasil, se coloca já em um nível mais profundo: rompe com o específico psiquiátrico e atrela o mundo da saúde mental àquele mais complexo da sociedade civil. (p. 15)

$\mathrm{Na}$ experimentação, entre erros e acertos, novas estratégias foram sendo encontradas para construir uma sociedade mais igualitária e inclusiva. Para seguir acertando, é necessário, antes de tudo, reconhecer que essa suposta divisão de mares não deve mais existir, afinal, estamos todos juntos no mesmo barco. O movimento de tomada de responsabilidade, tanto individual quanto coletiva, é o ponto de partida para a transformação institucional e para o processo de desconstrução.

Analisemos, assim, o mundo do terror, o mundo da violência, o mundo da exclusão, se não podemos reconhecer que esse mundo somos nós, já que somos as instituições, as regras, os princípios, as normas, as ordens e as organizações; já que não podemos reconhecer que fazemos parte do mundo da ameaça e da prevaricação pelo qual o doente se sente esmagado, tampouco somos capazes de entender que a crise do doente é a nossa crise... (Basaglia, 
2001, p.127)

2.4.2 - Os desafios da desinstitucionalização no plano sociocultural

Conforme aponta Bezerra Jr. (2007), para a Reforma Psiquiátrica não ser apenas mais uma proposta de modelo assistencial ou uma reforma administrativa, é necessário realizar uma verdadeira mudança paradigmática em diversos planos. $\mathrm{O}$ primeiro deles refere-se ao plano assistencial, em que devem ser pensadas novas formas inovadoras de organização da atenção, novos modelos de cuidado e intervenção adequados aos novos dispositivos. Planejar uma reforma contextualizada para os diferentes cenários socioculturais, uma ação específica para os pequenos municípios (como certas áreas amazônicas, por exemplo) e para as grandes megalópoles, baseando-se nas noções de rede e território.

$\mathrm{Na}$ esfera clínica, inerente ao plano assistencial, deve-se ampliar os dispositivos teóricos e a capacidade normativa psíquica, existencial e social do sujeito. Uma clínica ampliada que dialogue com outras categorias profissionais para aprimorar as estratégias terapêuticas. A esfera política envolve todo um esforço de consolidação do poder de indução que os órgãos de coordenação da atenção à saúde mental precisam exercer para estimular as transformações da reforma e avaliar o impacto de tais mudanças com critérios adequados para estimar subjetivamente e medir objetivamente o resultados das estratégias terapêuticas. A articulação entre os aspectos clínicos e políticos na atenção psicossocial, entre estratégias de cuidado e estratégias de responsabilização, são aspectos fundamentais nesse processo de transformação. (Bezerra Jr, 2007)

Nos planos jurídico e político a temática dos direitos humanos e da defesa da dignidade da pessoa deve ir além dos mecanismos de proteção jurídica baseada na argumentação médica, para discutir mecanismos jurídicos que possibilitem a inclusão civil e social, que ampliem a automomia do sujeito e sua inserção no campo da cidadania e do debate político. O plano sociocultural, o último apontado pelo o autor, também se vincula a essas dimensões, pois também exige ultrapassar as fronteiras do discurso técnico-psiquiátrico.

Ainda que Bezerra Jr. (2007) mencione esses desdobramentos da reforma com igual importância nos diferentes planos, considero o aspecto sociocultural o carro- 
chefe do ideário antimanicomial. O debate público sem os jargões e protocolos médico-psicológicos, a inclusão de diversos segmentos sociais, a valorização da dimensão existencial e humana do sofrimento, esses são os grandes catalisadores de uma transformação profunda em nossa sociedade. É impossível alavancar os demais campos sem antes dar a devida atenção a essa dimensão.

Apesar do lema "Um sociedade sem manicômios" representar um movimento social que requer a participação de todos, parece que a bandeira da luta antimanicomial diz muito pouco ou nada à população. Isso é grave. A própria luta, quando ainda consegue ultrapassar os corredores da saúde mental, continua enclausurada nos muros de um debate restrito aos profissionais da saúde. Como envolver toda a sociedade nessa luta se até a energia dos militantes se dissipa com as forças antagônicas no interior movimento?

Surgem então os impasses, do confinamento dos muros ao controle a céu aberto, o enclausuramento da loucura sendo reeditado através de um falso protagonismo. É através de cenas do cotidiano dos serviços, imagens, cenas que flagramos as engrenagens que mantêm o manicômio vivo. Alverga e Dimenstein (2006) apresentam de maneira muito clara essas forças antagônicas por meio de uma fotografia que apresentava dois planos: o primeiro correspondia a uma faixa com os dizeres "Loucura maior é o preconceito" e, no segundo plano, via-se uma corda de contenção aos usuários de saúde mental. Surgem então os paradoxos daqueles discursos mascarados de crítica ao preconceito e valorização social da loucura pelo direito de ocupação da cidade.

Dessa perspectiva, observa-se o movimento de forças instituintes circulando, buscando romper com a racionalidade da lógica manicomial, revitalizando o cotidiano de usuários no espaço urbano, fazendo a cidade e seus moradores experimentarem inquietações, mal-estar, o novo. Por outro lado, identificamos um movimento quase invisível coexistindo e expressando a manutenção de elementos que historicamente caracterizam o dispositivo psiquiátrico, evidenciados na corda, na contenção, no isolamento, no ordenamento, na massificação, no controle, na segregação dos loucos e dos "normais". (Alverga \& Dimenstein, 2006, p. 304)

A separação entre técnicos e usuários também era visível na dinâmica do refeitório dos serviços substitutivos. Embora comessem todos no mesmo cômodo, havia uma regra implícita que determinava a mesa como espaço exclusivo dos 
técnicos, a tarefa de lavar os pratos era destinada apenas aos usuários que curiosamente eram proibidos de entrar na cozinha. (Alverga \& Dimenstein, 2006) O funcionamento de tais práticas institucionais que encenam a inclusão, mostram o lado mais perverso dessa incessante disposição para a exclusão. Afinal, de boas intenções o manicômio está cheio. Diante desse quadro generalizado de cultura manicomial, não será um protagonismo ensaiado que mobilizará a população a ser apresentar a esta causa que lhe parece tão distante.

A saúde mental é a própria afirmação da vida. Ela está nos convívio em casa, nas relações com a comunidade, no trabalho, nos vínculos de amizade, nos espaços de lazer, no cinema, na música, na dança, no acesso à informação, na Constituição, na arquitetura da cidade, na expressão das artes, na alimentação, na relação com a natureza e com os animais, na sexualidade, no nascer e no morrer. As pessoas, de modo geral, não conseguem identificar a saúde em todos esses processos, já que não corresponde à saúde-que-aparece-na-mídia.

A mídia, ao publicizar certos fatos em detrimento de outros ou ao criar "seus fatos" coletiviza aquilo que lhe interessa. Ela transforma uma fato anônimo em um fato conhecido e compartilhado pela coletividade, ou seja, um fato coletivo. A questão central é que a saúde representada na mídia brasileira se revela apenas no corpo individual, da ordem do sofrimento privado, ou seja, "em regra geral, não instituem responsabilização solidária ou sentimentos de comunhão que, respeitando a diversidade, criem no receptor uma sensação de pertencimento a uma coletividade" (Lefèvre, 1999, p. 87). Apenas se discute Saúde Coletiva quando surgem as epidemias, momento em que o âmbito privado é suspenso temporariamente para que o Estado intervenha rapidamente no foco que ameaça a coletividade.

As caraterísticas da sociedade capitalista de consumo reforçam ainda mais essa dimensão individualizante. Ainda que a mídia informe a população sobre uma determinada doença, a recepção da mensagem torna-se privada pois o seu conteúdo remete a ação que cada consumidor deve individualmente seguir, os medicamentos a serem comprados, os tratamentos necessários, etc. Por outro lado, o plano midiático, ao controlar a falta de medicamentos em hospitais, por exemplo, mostra uma possível dialética entre o direito do cidadão e o dever do Estado. 
A saúde como um fato coletivo coloca em cena, necessariamente, o Estado e a Sociedade Civil porque a saúde, no plano coletivo, o que se entende vulgarmente por Saúde Pública, sempre foi e talvez continue sendo sempre, um "dever do Estado" (ainda que a ser exercido de variadas formas, nem sempre diretas) a ser "socialmente controlado" pela sociedade civil (Lefèvre, 1999, p. 89)

Esse panorama implica num aumento da tensão no binômio sociedadeloucura. Conforme dados do Ministério da Saúde, a estimativa de brasileiros que necessitam de algum atendimento em saúde mental corresponde a $12 \%$ da população, são 23 milhões de pessoas. Pelo menos cinco milhões de brasileiros, 3\% da população, são considerados transtornos mentais graves e persistentes. Essa enorme demanda, infinitamente desproporcional à oferta de serviços, pode estar associada às condições ecônomicas adversas, à violência urbana, além da falta de área recreativas nas grandes cidades brasileiras. (Gonçalves, et al., 2014) ${ }^{17}$ Se estamos falando de uma parcela considerável da saúde da nossa população, como não abordar esse tema abertamente com a sociedade?

Mesmo com o crescimento dos meios de comunicação de massa, especialmente a televisão e o barateamento dos aparelhos tecnológicos, tais informações continuam silenciadas. A ausência de uma cultura escrita por falta de condições educacionais e econômicas potencializou a repercussão da televisão aberta e do rádio, transformando-os em fontes de informação e de entretenimento. Presente em quase todo o território nacional, difundindo valores, costumes e comportamentos, a televisão teve um grande impacto social. O efeito da globalização/colonização reproduziu esquemas dominantes de significação e interpretação do mundo produzindo uma complexa circunstância cultural, com uma gama de identidades possíveis de serem desenvolvidas.

Como conseqüência disso, percebe-se o aparecimento de grupos que se

${ }^{17} \mathrm{O}$ estudo aponta a importância de se criar estratégias na educação que envolva competências nos profissionais que possam ir além do ato de diagnosticar e da gestão de medicamentos. O artigo conclui: "Finally, policy-makers must make efforts to reduce economic inequities and implement ed- ucational and public safety policies to overcome the vicious circle of poverty, urban violence and mental disorders, acting directly for promoting human wellbeing." (Gonçalves, et al., 2014, p. 629) 
constituem não pelos critérios de agrupamentos tradicionais como raça ou classe, por exemplo, mas se orientam segundo critérios de saúde, de performances corporais ou doenças específicas. Para distinguir essa nova forma de organização social que se difere do biopoder clássico, Ortega (2008) discute a noção de biossociabilidade. O autor explica que uma nova lógica sobre mérito, valores e reconhecimento é instaurada a partir de um ideal de saúde. Isso significa dizer que, através se faz uma avaliação individual, a boa saúde passa a ser um atributo moral. As bioidentidades são fortemente marcadas pela constante cuidado de si, pelos procedimentos médicos, corporais, higiênicos que fazem parte do autocontrole. Outro aspecto marcante é o corpo sempre modelado pelo olhar censurado do outro que vai reforçar a responsabilidade que o indivíduo tem sobre as suas escolhas e estilo de vida e a necessidade de buscar a perfeição corporal e afastar comportamentos de risco à saúde. A ênfase nessa noção de indivíduo autônomo e auto-suficiente reforça a ideia da dependência ${ }^{18}$ como algo vergonhoso. No entanto, a noção de autonomia individual, tão valorizada em nosso país, revela a fragmentação da assistência, devolvendo ao indivíduo a responsabilidade por sua saúde para desafogar o sistema público. As pessoas dependentes tornam-se indesejadas, passam a ser vistas como "parasitas sociais" (Ortega, 2008).

Se a força, a juventude, a beleza busca pela saúde e a autonomia do cuidado de si que são valorizados, a obsessão pelos corpos sarados, lipoaspirados, siliconados reforçam um padrão irreal de corpo ideal, que contribui desde a disseminação do preconceito com aqueles que não alcançam esse modelo até o aparecimento de doenças como a bulimia, anorexias e depressões. Restariam aos corpos subalternos duas saídas, a adequação ou o ocultamento dos seus modos de existir desviantes.

Essa disposição certamente contribuiu para que parcelas significativas da intelectualidade e das elites alimentasse preconceito contra a televisão, sendo encarada como um mero aparelho ideológico. Entretanto, o sentimento de resistência contra o monopólio dos meios de comunicação e a mercantilização da cultura parece se fundir ao de incompreensão sobre as novas sociabilidades. O grande problema é

\footnotetext{
${ }^{18}$ A dependência como algo vergonhoso interfere inclusive na representação da velhice, como algo deplorável. Em sociedades mais politizadas, a experiência de dependência de modo algum é encarada como humilhação, ao contrário, o senso de mútua dependência é entendido como base da ligação social.
} 
que, enquanto o tema da mídia continuar sendo desprezado nas pautas políticas desse país, estaremos desperdiçando um enorme potencial de transformação estrutural.

Tanto o sistema de saúde quanto o sistema midiático estão a serviço de interesses privados - seja dos próprios meios ou do poder político. A grande mídia constitui um importante poder econômico no Brasil e, no entanto, somente três grupos controlam cerca de $70 \%$ do mercado da comunicação. Como nos lembra o Fórum Nacional pela Democratização da Comunicação - FNDC, a família Marinho, por exemplo, proprietária do império midiático das Organizações Globo, soma a maior fortuna do Brasil: cerca de 29 bilhões de dólares. Essa concentração e a ausência de pluralidade e diversidade trazem implicações graves para as políticas públicas do país que usam a influência da mídia para pautar o debate público em benefício próprio, trazendo prejuízos aos interesses da maioria da população. 


\section{CAPÍTULO III - O DIREITO DE COMUNICAR A DIVERSIDADE}

\section{1 - Comunicação é direito de todos}

Já é sabido que a globalização é um processo não-homogêneo, desigual e instável (Hall, 2006) que, muitas vezes, colabora para a afirmação de culturas hegemônicas, reforça as relações de poder e a invisibilidade de grupos subalternos. No entanto, é justamente por meio da apropriação desses mesmos recursos tecnológicos e midiáticos que se torna possível subverter o jogo da exclusão. $\mathrm{O}$ mesmo instrumento que silencia certas vozes pode empoderá-las se o sentido da democratização da informação for resgatado em nossa sociedade como aspecto inerente à cidadania.

O acesso à informação e aos canais de expressão são direitos à cidadania e à cultura, muitas vezes, deixados em segundo plano. A interdição desses direitos alimenta preconceitos e mantém a população cega em relação a outras dimensões da cidadania que lhe são negadas. Tal direito circunscreve-se em três diferentes níveis: o de primeira geração, o qual corresponde à dimensão civil que assegura a liberdade de opinião e expressão de ideias; o de segunda geração, que prevê acesso aos bens; e o de terceira geração, que envolve a noção de direito coletivo, grupos, movimentos e suas diversidades. Esses diferentes níveis interpenetram-se, variando conforme o contexto. Se, em alguns espaços, estão em discussão direitos de quarta geração, em outros, ainda se lutam por direitos civis, políticos e sociais (Peruzzo, 2011).

Falar de acesso à comunicação, em tempos de globalização, refere-se a direitos que estão muito além da garantia do recebimento de informações. Ainda que estivesse sob análise o cidadão apenas como espectador, também é pressuposto o direito ao acesso a informações fidedignas e livres de preconceitos. No entanto, quando a mídia permanece concentrada nas mãos de grandes grupos econômicos e políticos, a garantia de que esses direitos sejam efetivamente exercidos de forma democrática torna-se um grande desafio, principalmente, quando se trata do acesso aos canais de comunicação, ou seja, do poder de comunicar.

A Constituição Brasileira de 1988, no capítulo de Direitos Individuais e Coletivos, inciso IX, expressa: "é livre a expressão da atividade intelectual, artística, científica e de comunicação, independentemente de censura ou licença”. Significa 
dizer que o acesso à comunicação, em seu entendimento amplo, é o próprio catalizador da cidadania, é o incentivador da participação direta do cidadão na esfera pública comunicacional. E ainda, no capítulo V, da Comunicação Social, fica explícito no Artigo 221 alguns princípios aos quais a produção e a programação das emissoras de rádio e televisão deveriam atender. São eles: I - preferência a finalidades educativas, artísticas, culturais e informativas; II - promoção da cultura nacional e regional e estímulo à produção independente que objetive sua divulgação; III regionalização da produção cultural, artística e jornalística, conforme percentuais estabelecidos em lei; IV - respeito aos valores éticos e sociais da pessoa e da família.

A partir desses trechos, torna-se evidente que todo cidadão, juntamente com suas organizações coletivas, pode (e deve) participar dos canais de informação e comunicação. Sem dúvida, "a democracia no poder de comunicar é condição para ampliação da cidadania" (Peruzzo, 2011, p. 34). A dimensão cultural é porta de entrada para colocar em questão a democratização nos âmbitos da economia e da política, evocando outras dimensões da cidadania. Além disso, a diversidade, como característica essencial da humanidade, deve ser valorizada e cultivada para que as capacidades e os valores humanos continuem promovendo o desenvolvimento das comunidades. A Convenção da Diversidade Cultural, produto da Conferência Geral da Organização das Nações Unidas para Educação, afirma que "a liberdade de pensamento, expressão e informação, bem como a diversidade da mídia, possibilitam o florescimento das expressões culturais nas sociedades" (UNESCO, 2005).

No relatório produzido pela UNESCO (2014) sobre as Tendências mundiais a respeito da liberdade de expressão e do desenvolvimento de mídia, foram utilizados alguns conceitosanorteadores: a liberdade, o pluralismo, a independência e a segurança. Resumidamente, A liberdade diz respeito aos fluxos de informação pública moldados pela mídia e pelo jornalismo. O pluralismo é conceituado como uma questão de propriedade e controle econômico referindo-se aos tipos e números de meios de comunicação disponíveis em um sistema político específico. Essa dimensão incorpora considerações sobre a diversidade de conteúdos de informação, notícias, opiniões políticas, questões de representação (assim como a presença equitativa de mulheres) e a consideração de interesses conflitantes. Em outras palavras, o pluralismo midiático envolve uma ampla gama de valores sociais, políticos e culturais 
baseada nos direitos humanos universais. Apesar do relatório apontar a importância da manifestação desses direitos nas plataformas públicas de mídia, reconhece que, "com algumas exceções, não tem havido progresso no apoio às rádios comunitárias e aos serviços públicos independentes de radiodifusão, como elementos de um cenário pluralista da mídia." (UNESCO, 2014, p. 21).

Outros conceitos abordados no relatório são: a independência, relacionada à liberdade de interferência externa, política ou comercial; e a segurança que protege o jornalismo de crimes. A ausência de segurança pode nos conduzir à autocensura, comprometendo o pluralismo. (UNESCO, 2014). Ainda que se fale em mídias democráticas, percebo que o jornalismo brasileiro ao limitar a extensão possível do pluralismo, não apenas compromete a independência editorial e exclui a escolha ética, mas prejudica o direito de toda a sociedade de se manter informada. $\mathrm{O}$ respeito a esses princípios relatados é a base para que certos temas, como a saúde mental por exemplo, pudessem ser abordados de forma aberta, sem manipulações ou constrangimentos.

A existência da liberdade de imprensa, em suas dimensões múltiplas de liberdade midiática, pluralismo, independência e segurança, fortalece a paz e os processos democráticos e de desenvolvimento. Esses bens sociais dependem de as pessoas poderem ser livres para falar sem medo e de serem informadas livremente sobre assuntos públicos. (UNESCO, 2014, p. 8)

Segundo Peruzzo (2011), apesar do direito à comunicação estar ganhando cada vez mais espaço, o tema enfrenta dificuldades quanto à mobilização popular. A defesa pelo direito à comunicação recebe menos importância em relação às questões dos direitos humanos, sendo encarada pelos governos e pela sociedade civil como uma demanda menos urgente. Além do Direito de Informação e do Direito de Comunicação serem áreas novas, a visibilidade dessa discussão parece estar ainda restrita àqueles que se dedicam especificamente à mídia e à comunicação.

Essa leitura - fragmentada pelos campos de conhecimento - revela que a cidadania é um termo em disputa. Desse modo, novas dimensões devem ser conquistadas e agregadas a uma noção de cidadania para uma leitura complexa e condizente com o cenário atual. Entretanto, a ampliação desse conceito ou o estabelecimento de direitos legais, por si só, não garantirá a igualdade de acesso desses direitos. Infelizmente, essa afirmação não é suficiente para reverter seus descumprimentos. 
Com o objetivo de democratizar a mídia para reformar a política, surge, a partir da mobilização de dezenas de entidades do movimento social brasileiro em São Paulo, em 2012, a campanha "Para Expressar a Liberdade - Uma nova lei para um novo tempo", uma iniciativa do Fórum Nacional pela Democratização da Comunicação (FNDC). Essa proposta é resultado de um processo fomentado desde 2009, quando a sociedade civil, o poder público e parte do setor empresarial discutiram propostas para a construção de políticas públicas para a comunicação do país na I Conferência Nacional de Comunicação (Confecom). Tal como na conferência em saúde mental, esse evento representou uma conquista importante dos movimentos sociais. Entretanto, as propostas aprovadas na Confecom permaneceram engavetadas, não existindo nenhum debate público estabelecido. A campanha é uma forma de debater com os mais amplos segmentos da sociedade os motivos pelos quais o Brasil tem urgência em ter uma nova lei para garantir o direito à comunicação.

\section{2 - Comunicação comunitária e saúde mental}

Se a construção da cidadania diz respeito a um processo histórico de lutas, a comunicação comunitária, do mesmo modo, teve seu surgimento no interior dos movimentos populares. A partir da organização de agrupamentos sociais com pautas definidas e com objetivos claros de conscientização, os meios de comunicação atenderam à necessidade de estabelecer um canal de comunicação entre os membros de um grupo e desse grupo com a sociedade. Esse tipo de processo comunicacional tem como objetivo defender os interesses de uma comunidade, visando a transformação social para uma sociedade mais igualitária (Peruzzo, 2011).

O fazer coletivo desse processo popular torna-se um espaço de participação ativa de pessoas pertencentes a classes subalternas que contribuem para a democratização da informação. Apesar de não ter o mesmo alcance que as mídias tradicionais, quando a voz subalternizada consegue falar para as grandes massas, o envolvimento comunitário é reavivado. A boa notícia é que, gradativamente, a comunicação comunitária vem ocupando seu espaço com mídias alternativas (por exemplo, a Tv Justiça, Tvs universitárias, etc) que já possuem representatividade local. (Peruzzo, 2011) Essa abertura pode ser entendida como resultado do processo contraditório de globalização. Se por um lado há um intenso crescimento da 
homogeneização cultural em função da sociedade do consumo ${ }^{19}$, há simultaneamente uma força de resistência que faz aparecer identidades locais e regionais que, até então, não apareciam (Hall, 2006).

Por sua vez, quando o tema da saúde mental é apresentado nas grandes mídias, não por acaso, observamos uma tendência a uma abordagem rasa na apresentação dessa problemática a fim de evitar um embate com os conceitos socioculturais predominantes. Os discursos libertários apresentados nas telas são, em geral, dissimulados e ignoram as contradições sociais inerentes ao campo. Nesse sentido, os dispositivos midiáticos funcionam como dispositivos ideológicos à medida em que obedecem à ordem do consumo e do mercado hegemônico, distorcendo a representação da realidade (Soares, 2004).

Percebe-se, portanto, que as mídias alternativas surgem justamente como uma resposta de resistência à homogeneização a partir da legitimação de novas produções de sentidos. Os meios de comunicação de uso comunitário, em especial, no campo da saúde mental, terão uma representação ainda mais forte: de espectador aprisionado pelo estigma da loucura, o usuário de saúde mental se torna protagonista de sua própria história de vida e o principal agente transformador da vida de outras pessoas.

Nos últimos anos, observa-se um crescente reconhecimento da capacidade dos usuários de saúde mental em exercer um papel mais ativo em relação a decisões sobre práticas e cuidados em saúde. A lei da Reforma Psiquiátrica (Lei n ${ }^{\circ} 10.216$ de 6 de abril de 2001), representa um avanço na transformação do paradigma psiquiátrico tradicional, pois na tentativa de abolir o sistema asilar, busca conservar, mesmo em tratamento, os direitos e deveres civis do sujeito em sofrimento psíquico grave.

Frente a esses avanços, por que o conceito de doença mental tem sobrevivido no imaginário social? Reduzir a loucura à doença mental implica em uma série de compreensões errôneas que limitam a compreensão do sofrimento existencial a um defeito de ordem neurológica, fazendo com que qualquer ação do sujeito confirme sua "falta de razão" (Szasz, 1980). A noção de incapacidade e de desrazão criadas por esse estigma, somada ainda a um potencial de periculosidade serve convenientemente

\footnotetext{
${ }^{19}$ A leitura de Bauman (2007) sobre as identidades contemporâneas indica que a individualização se tornou uma norma na sociedade de consumo e que a multiplicidade de estilos de vida se constitui como práticas seletivas de consumo, constitutivas de identidades provisórias. Ou seja, na sociabilidade líquida, as identidades ganham livre curso e são escolhidas no "supermercado cultural" de acordo com o poder de consumo. Na tentativa de construir uma identidade para si, os indivíduos acabam buscando as mesmas estratégias de vida e usando símbolos comuns produzindo uma homogeneização cultural.
} 
como justificativa para o isolamento e o abandono nas instituições psiquiátricas. Como vimos, paradoxalmente o manicômio, mesmo apresentando intenções não violentas, acaba se tornando uma instituição de violência já que, ao reduzir o complexo fenômeno da loucura à doença mental, retira toda a possibilidade de interlocução e exclui o sujeito de toda possibilidade de vida (Basaglia, 2001)

A mídia tem sua parcela de responsabilidade na perpetuação desse mito, pois reproduz práticas discriminatórias baseadas em pressupostos de neutralidade e incontestabilidade da autoridade científica. $\mathrm{O}$ não-questionamento e o silêncio sobre essas problematizações são sinais de conivência com a objetalização dos sujeitos e de obediência à ordem hegemônica. Além de manter os pilares da psiquiatria tradicional, o mito da doença mental sustenta um projeto civilizatório baseado num sistema de razão que incorpora a violência e a exclusão como uma necessidade ou uma finalidade educativa. Adaptar indivíduos à aceitação de condição de objetos de violência, cala não só o sujeito que está em sofrimento, mas silencia também os conflitos morais nas relações humanas e evita o confronto com nossa insegurança na própria condução da vida. Em outras palavras, o mito assujeita toda a sociedade.

Interessante notar que a população, em geral, entende o conceito de doença mental frequentemente associado a comunicações que expressam ideias inaceitáveis, organizadas dentro de uma linguagem incomum (Szasz, 1980). A mídia, enquanto instrumento político e pedagógico, pode se tornar um importante aliado da Reforma Psiquiátrica. À medida em que os meios de comunicação contribuem para a propagação de argumentos que desestabilizam o estigma da loucura, reconhecendo que a expressão humana excede a inteligibilidade e a norma, novos modos de se organizar e de existir no mundo podem ser percebidos como legítimos. Dar ao público a chance de conhecer e se reconhecer em sua diversidade é tornar a cidadania a linguagem comum em nossa sociedade.

Nesse sentido, a construção coletiva desse protagonismo, possibilitada pela atitude epistemológica proposta por Basaglia, tem como estratégia de intervenção não a cura ou reabilitação dos usuários, mas a promoção da saúde e de formas que produzam um usuário-ator, sujeito político (Torre \& Amarante, 2001). A desconstrução das práticas de institucionalização da loucura está muito além da implementação de serviços substitutivos em saúde mental, corresponde a uma efetiva 
transformação no campo da saúde mental capaz de interromper o processo de assujeitamento, tanto dos usuários quanto dos profissionais da saúde.

Significa dizer que para produzir essas mudanças na qualidade das relações humanas, não basta apenas humanizar a assistência psiquiátrica, mas envolver todo um cenário crítico em relação à neutralidade científica e a ideologia dominante que apaga toda forma de diversidade para atender às exigências de produtividade baseada em discursos normatizadores. Para romper com a lógica excludente, a Reforma Psiquiátrica deve ocorrer em um nível mais profundo, ou seja, deve interpelar a cada um de nós para o reconhecimento de nossos próprios manicômios mentais.

A Reforma Psiquiátrica, tendo como meta a desinstitucionalização, tornou evidente a necessidade de resgate dos direitos de cidadania dos pacientes psiquiátricos em nosso país. Ela se apoia num novo paradigma de cuidados em saúde mental envolvendo um conjunto de cuidados que tenha uma incidência efetiva no cotidiano das pessoas assistidas, desenvolvendo possibilidades expressivas diversas. Desinstitucionalização abrage todos os espaços que o sujeito participa, todas as instituições em que se estabelece uma relação entre a norma e a diversidade. Por isso, ao propor a reinserção do usuário de saúde mental ao ambiente social é necessário compreender outras questões de ordem social que estão implicados nesse campo, como por exemplo, o debate sobre as diferenças de classe, gênero, raça, idade, religião, etc. Reconhecer as particularidades de cada um desses recortes é o primeiro passo para compreender a realidade em sua complexidade.

A Saúde Mental vem se atualizando, certamente em um ritmo muito mais lento se comparado ao mundo das telecomunicações, mas continua a ampliar a própria a noção de tratamento, de terapêutica e de cuidados a partir da incorporação de novos mecanismos, instrumentos e conceitos em uma perspectiva mais horizontal de relações (Amarante \& Nocam, 2012). A inauguração de espaços de convivência que incorporam a política antimanicomial tem um papel importante na transformação social do estigma e na abertura de novas possibilidades de vida daqueles que estiveram antes privados de todos os seus direitos.

Em oposição ao modelo impositivo que impera na grande maioria dos hospitais psiquiátricos, os espaços de convivência dão espaço à liberdade de 
expressão dos sujeitos através de atividades desenvolvidas por meio de diferentes oficinas. Nesse sentido, se pensar o sofrimento mental hoje é inscrevê-lo num espaço criativo e inclusivo, a parceria entres núcleos de comunicação comunitária com esses espaços parece ser um caminho interessante que está muito além do registro e divulgação das oficinas, já amplia as possibilidades de transformação das relações, das subjetividades e da sociedade.

Os profissionais de saúde, familiares, usuários de saúde mental precisam acreditar que existe vida para além dos muros hospitalocêntricos, ou melhor, que uma nova vida possa se fazer existir com a inexistência dos muros - concretos e simbólicos. Nem sempre é fácil ir contra a correnteza, mesmo os militantes tem suas forças ideológicas esgotadas quando confrontados com a realidade, mas somos alimentados por histórias e, em alguma medida, ao ouvi-las permanecemos acreditando que todo esforço é válido para a construção de um modelo mais justo de sociedade. A experiência da Tv Sã é uma história que merece ser contada.

3.3 - Escutando as vozes: a proposta de uma tv comunitária em Saúde Mental

A TV Sã - Núcleo de Comunicação Comunitária em Saúde Mental do Distrito Federal - é um projeto interdisciplinar que visa a construção e divulgação de vídeos que incitam debates com a sociedade sobre a temática da saúde mental. O projeto nasceu na semana comemorativa da Luta Antimanicomial, no período de 14 a 18 de maio de 2008 em uma oficina de vídeo ministrada pela TV Pinel (RJ) que teve por objetivo por em funcionamento no Distrito Federal uma proposta inovadora no campo da saúde mental articulando diferentes espaços como a Inverso, CAPS, universidades, entre outros.

\subsection{1 - Tv Pinel: por uma nova imagem da loucura}

Desde 1996, a Tv Pinel vem produzindo programas com funcionários e usuários do Instituto Philippe Pinel, em Botafogo, com a parceria da Secretaria Municipal de Saúde do Rio de Janeiro. Entre quadros de humor e pararódia, reportagens sobre a luta antimanicomial e vinhetas, são organizados numa linguagem própria um tipo de revista televisiva. Os programas, quando não são interrompidos pela dificuldade financeira, ocorrem trimestralmente, além da exibições que acontecem em praça pública, em média, duas vezes ao ano. 
Na TV Pinel, não há a camisa de força do ibope, do mercado, da publicidade para ditar a produção. O tempo também não é o industrial, imposto pela produtividade em série, mas cria-se e re-cria-se no tempo comunal, isto é, no tempo dos usuários, técnicos, funcionários, corpo médico que, mesmo com responsabilidade e um cronograma a cumprir, deve ser respeitado. (Miranda, 2007, p. 200)

Nessa experiência em Tv comunitária, antes do resultado estético, está o valor ético que traz a marca da proximidade imagem-espectador. Os participantes protagonizam suas narrativas, contam sobre suas vidas cotidianas e estabelecem um vínculo com a comunidade. O eixo central não é a questão psiquiátrica da TV Pinel, mas o processo de realização de vídeos, um lugar de questionamento da experiência de ver e de produzir imagens. (Miranda, 2007) Por meio de uma metodologia participativa que busca materializar os desejos de usuários, técnicos, familiares e profissionais da saúde mental a partir de um roteiro audiovisual.

A Tv Pinel já recebeu várias premiações em festivais de vídeos nacionais e internacionais. Inicialmente recebeu financiamento pelo Ministério da Saúde e atualmente têm seus contratos efetuados via município. Técnicos de vídeo, jornalismo, câmeras e usuários que atuam em funções fixas e específicas, recebem pagamento pelo desempenho de seus trabalhos profissionais. (Soares, 2004)

Estabelecendo uma comparação com a Tv diária, ela instiga uma curiosidade no telespectador ao propor uma "outra" imagem, inabitual, sobre a loucura. Essa nova cara surge livre dos estereótipos, nasce de um engajamento coletivo, de um compromisso em discutir a democratização dos meios de comunicação e, ao mesmo tempo, reverter à exclusão (Miranda, 2007). Tal a Tv Pinel escreve em seu blog, "sua proposta é 'enlouquecer', 'delirar', transformar, reinventar a mídia televisa e possibilitar 'diferentes olhares da loucura' ”. (Tv Pinel, 2013)

\subsection{2 - ONG Inverso: espaço de re-criação}

A Inverso - Instituto de Convivência e Recriação do Espaç̧o Social - é um espaço inovador no campo da saúde mental. Construída em 2001 por militantes, pouco tempo depois da promulgação da Lei 10.216, a instituição abriu as portas para a desinstitucionalização chegar no DF, já que naquela época ainda não havia nenhum CAPS implantado. No caminho "inverso" às práticas manicomiais, esse espaço tornou-se um dispositivo de socialização e inclusão. 
Os Centros de Convivência e Cultura vem se destacando como um dispositivo inovador, concebido no território da cultura e da cidade que assume um pelo papel estratégico de expansão da Reforma Psiquiátrica e atenção substitutiva em saúde mental. Seu valor para a inclusão social reside no fato de ser um equipamento concebido fundamentalmente no campo da cultura, e não exclusivamente no campo da saúde. Sendo assim, não são assistenciais e tampouco realizam atendimento médico ou terapêutico. "São dispositivos públicos que se oferecem para a pessoa com transtornos mentais e para o seu território como espaços de articulação com a vida cotidiana e a cultura." (Brasil, 2005, p. 38).

Os usuários de saúde mental não são chamados de "usuários" na Inverso termo que, para muitos, está carregado de um sentido pejorativo associado a "usuários de drogas" - são, portanto, chamados de frequentadores. Os estudantes são frequentadores, assim como os profissionais e demais pessoas que ali estiverem. É um espaço livre, de exercício da conviência, aberto a toda a comunidade. Não há exigências burocráticas ou qualquer cadastramento para frequentar o local, assim como também não há obrigatoriedade de participação nas oficinas.

A autonomia e a liberdade está presente na Inverso simbólica e concretamente. A chave da instituição, o mesmo instrumento de aprisionamento da loucura, aqui abre portas. Alguns frequentadores tem a chave da instituição em sua posse, eles controlam o horário de abertura e fechamento, além de criar um sentimento de pertencimento, de responsabilidade e de cuidado com o espaço. A chave da instituição é chave da desinstitucionalização.

A Inverso parece ter uma boa receptividade na quadra - 408 norte. Os frequentadores são queridos pela vizinhança. No caminho até a Inverso, estão as amizades com os funcionários do bicicletário ao lado, da confeitaria da esquina, o apoio recebido pelo bar Pinella, entre outros. A esquina da Loucidez, espaço produzido com um trabalho de mosaicos dos frequentadores, também dá seu toque de arte e cultura.

Baralho, cigarro (e a negociação de onde se pode fumar), violão, conversa, jogos, debate, tudo faz parte das trocas sociais que se estabelecem entre os frequentadores. Fotografia, inglês, percussão, artesanato, são algumas das atividades que ocorrem durante a semana na Inverso, coordenadas por profissionais voluntários. Dentre elas, está a produção de vídeos do grupo Tv Sã. 


\subsection{3 - A experiência da Tv Sã}

A TV Sã - Núcleo de Comunicação Comunitária em Saúde Mental do Distrito Federal - é um projeto interdisciplinar que visa a construção e divulgação de vídeos que incitam debates com a sociedade sobre a temática da saúde mental. O projeto nasceu na semana comemorativa da Luta Antimanicomial, no período de 14 a 18 de maio de 2008 em uma oficina de vídeo ministrada pela TV Pinel (RJ) que teve por objetivo por em funcionamento no Distrito Federal uma proposta inovadora no campo da saúde mental.

A escolha do nome "TV Sã", bem como todas as decisões que envolvem o Núcleo, foi uma decisão coletiva feita por meio de votação. Até então, desde a sua criação, o grupo era chamado de Núcleo de Comunicação Comunitária em Saúde Mental do Distrito Federal. No dia sete de março de 2009, em uma reunião no UniCEUB, foi feito um levantamento de nomes possíveis, sugeridos por todos os participantes que quiseram contribuir e, em seguida, o nome TV Sã foi eleito, por ser um nome curto e revelador da proposta de geração de saúde por meio do exercício da cidadania e da inclusão social.

O Núcleo conta com a participação voluntária de usuários de saúde mental, familiares, profissionais da saúde e estudantes que se encontram semanalmente para o planejamento e execução de atividades. Trata-se de um grupo aberto em que as pessoas podem participar na medida de seu interesse e disponibilidade, assumindo as funções que lhes interessarem. A não obrigatoriedade nos trabalhos desenvolvidos não implica no descomprometimento dos participantes, ao contrário, contrastando com a experiência institucionalizada, a liberdade de escolha na participação das atividades é primordial para que a oficina se realize. Ainda que essa proposta leve à redução do número de voluntários, o engajamento do grupo deve se construir livre de forças coercitivas para que os vídeos não se tornem artificializados pela construção mecânica de um processo esvaziado de sentidos.

Por meio da realização das oficinas de vídeo, foram produzidos em 2008 duas curtas-metragens com a participação de técnicos e usuários de saúde mental de diversas instituições de saúde do DF (HSVP, ISM, CAPS Paranoá, CAPS AD Guará, Inverso, entre outras), e profissionais e estagiários de Psicologia e Comunicação 
Social do UniCEUB ${ }^{20}$. Para o Além e Vizinhos do Barulho representaram o pontapé inicial das produções da Tv Sã, sendo ambas as produções caracterizadas pela intervenção urbana em espaços públicos e colaboração espontânea de pessoas que compartilharam conosco suas impressões sobre a temática sugerida em cada vídeo.

Ainda no mesmo ano, junto à TV Pinel, foi finalizado o vídeo Efeitos Colaterais: Um Dia no Mundo dos Remédios, construído em parceria com os participantes da Inverso - Centro de Convivência e Cultura. A repercussão positiva dessa primeira experiência de parceria foi imprescindível na motivação e continuidade dos trabalhos do núcleo de comunicação comunitária. A TV Sã, com o objetivo de potencializar as modificações propostas pela Reforma Psiquiátrica, tornou-se um lugar de (re)descobertas: não só de novos espaços sociais (público, político), mas de novas habilidades criativas e relacionais.

Posteriormente a Tv Sã registrou as vozes da Marcha Nacional dos Usuários de Saúde Mental, evento histórico realizado no dia 30 de setembro de 2009 na capital do país que reuniu militantes, usuários e familiares de todo o Brasil. O vídeo $M e$ escuta, Brasília foi exibido no III Congresso Brasileiro de Saúde Mental em Fortaleza, além de debates e rodas de conversa em universidades brasilienses ${ }^{21}$. Outros eventos também foram filmados e fotografados, por exemplo o Desfile Dasloukas $^{22}$ e o Bloco do Rivotril. O último projeto realizado pelo grupo Tudo acontece em família (2015), inclui a participação dos familiares que compartilham suas histórias, falam sobre os desafios e as descobertas na convivência com pessoas em sofrimento.

A construção do vídeo Efeitos Colaterais: Um Dia no Mundo dos Remédios foi realizada por meio de pessoas sensíveis à luta antimanicomial e com habilidade para sensibilizar outras pessoas. Elias Lima e José Alves, por meio dos vínculos

\footnotetext{
${ }^{20}$ O Núcleo foi inicialmente sediado no UniCEUB - Centro Universitário de Brasília, instituição que, a partir de seus projetos pedagógicos de extensão, tem apoiado o grupo no sentido de oferecer o espaço para as reuniões e emprestar o equipamento audiovisual, quando é possível. Professores e alunos de Psicologia e Comunicação Social participaram voluntariamente da TV Sã, compondo uma aliança entre a instituição de ensino e as instituições de saúde.

${ }^{21}$ Universidade de Brasília (UnB), Centro Universitário de Brasília (CEUB), Centro Universitário IESB - Ceilândia e Universidade Católica de Brasília (UCB).

${ }^{22}$ Evento realizado no Hospital São Vicente de Paula (HSPV) em que os participantes das oficinas produzem peças de roupas e outros acessórios artesanais que são exibidos em desfiles, onde as passarelas estreladas pelos internos.
} 
afetivos construídos nas instituições, mobilizaram usuários de saúde mental a participarem do projeto e abrilhantaram o vídeo com suas atuações. Tânia Inessa contagiou seus estudantes com suas aulas de psicopatologia, compartilhando sua paixão pela saúde mental e levando, posteriormente, a experiência da Tv Sã a se transformar em um projeto extensão do curso de Psicologia. Eva Faleiros apoiou as atividades desenvolvidas com os frequentadores da Inverso e acompanhou todo o processo de perto. Profissionais da comunicação e estudantes de Psicologia também somaram forças. Foi assim que a roda de participantes foi crescendo, se diversificando e estreitando cada vez mais os laços da Inverso com a Tv Sã.

O suporte da Tv Pinel foi indispensável nesses primeiros passos de aprendizagem, inclusive para a definição mais clara de cada uma das etapas de construção do vídeo. No início do projeto, nenhum participante tinha conhecimento prévio sobre essas etapas, a novidade do mundo das comunicações colocou todos em condição igual de aprendiz. Ali, o conhecimento psiquiátrico não tinha nenhuma utilidade para manuseio correto dos equipamentos de filmagem ou edição. Nesse campo novo em que as participações dependiam unicamente da capacidade de estar com o outro e da disposição para descobrir novas habilidades, o poder do saber médico foi convidado a se retirar.

Durante os quatro primeiros anos da Tv Sã, o UniCEUB foi uma parceria importante para que o grupo pudesse utilizar pela primeira vez laboratórios de produção midiática. Com o auxílio de técnicos da comunicação aprendemos a editar vídeos e a entender o funcionamento básico de uma ilha de edição. Além disso, o grupo contou com o apoio da universidade para a confecção do primeiro DvD. Entretanto, a agenda apertada do departamento de comunicação e a parceria recémconstruída com a Inverso fez com que o grupo migrasse para lá, uma mudança que estreitou os laços com seus frequentadores.

Atualmente a Tv Sã também participa da comissão de comunição do Movimento Pró-Saúde Mental do Distrito Federal- MPSMDF e participa de vários outros espaços e serviços debatendo o tema da saúde mental. Essa história que teve início com a Tv Pinel foi ganhando autonomia. Hoje as edições acontecem numa "ilha de edição móvel", mas mesmo sem contar com recursos financeiros, o desejo do grupo é construir sua própria ilha de edição na Inverso e estabelecer novas parcerias. 
3.3.4 - As produções áudio-visuais do grupo

Considero válido descrever brevemente as principais produções áudio-visuais da Tv Sã para nos apropriarmos de mais elementos que revelam o seu funcionamento e sua relação com os serviços de saúde mental. Percebe-se que o intervalo entre 2010 e 2015 não houve nenhum outro vídeo produzido. Isso ocorreu em função de projetos iniciados a convite de algumas instituições, mas que não puderam ser concluídos pela falta de clareza e de apoio à proposta da Tv Sã. "Cobrir um evento" ou apresentar uma visão ingenuamente otimista sobre os serviços foge ao perfil do grupo que preocupase em defender prioritariamente os interesses do usuário de saúde mental.

A iniciativa de estabelecer parcerias deve contar com a participação da equipe dos serviços na divulgação da oficina de vídeo, no remanejamento na agenda da instituição e principalmente no incentivo à descoberta de novas habilidades. A postura de desinteresse da equipe técnica no projeto da Tv Sã e a descrença na capacidade dos possíveis participantes na produção de vídeos inviabiliza esse trabalho que tem como essência o envolvimento coletivo. Quando a voz da instituição parece mais alta que a voz das pessoas, então o projeto deve ser abortado.

Ainda que os usuários-participantes do projeto tenham um discurso excessivamente institucionalizado, é possível resgatar, em alguma medida, a dimensão pessoal de seu discurso que revelam a desumanização dos serviços. No entanto, resgatar a crítica pessoal da equipe técnica em relação à instituição é o mais difícil, pois em função de seu cargo, frequentemente pessoa e instituição se confundem. Tomado por um discurso político, o profissional de saúde, mesmo sabendo das violências rotineiras aos direitos dos usuários, anuncia ao público o "excelente" trabalho realizado nos CAPS, afinal, é preciso mostrar trabalho - mesmo quando ele não é feito. É claro que isso não se aplica a todos, existem profissionais efetivamente comprometidos com os interesses da população mas que, numa confusão de papéis, recebe a crítica ao funcionamento da instituição como uma crítica pessoal sobre a sua conduta, mesmo que os problemas sejam de ordem estrutural.

Nesse sentido, é fundamental que o profissional de saúde se desinstitucionalize em seu discurso para que possa representar a instituição de forma mais realísta intermediando com atenção os interesses da população e do governo, sem deixar que a voz do mais forte fale mais alto. Observando essas questões, é 
possível evitar que a manicomialidade impossibilite a realização de um projeto comunitário e coletivo. Ainda que alguns projetos não tenham sido finalizados, a experiência do erro também ensinou o grupo a aprimorar suas atividades e estreitar as relações com as instituições parceiras e com a população. A síntese sobre as produções áudio-visuais é exemplo de alguns acertos:

\section{Para o Além (2008)}

O que você faria se uma pessoa surtasse na sua frente? Para onde ela deveria ir? São essas perguntas que norteiam todo o processo do vídeo que retrata a pluralidade de soluções apresentadas pela população para lidar com essa situação de crise. Para conhecer a opinião das pessoas, foi realizada uma encenação na rodoviária do Plano Piloto. Ali, uma pessoa mostrava-se desorientada em meio à multidão, andando de um lado ao outro, gritando com uma voz que só ela estaria ouvindo. Em função de seu estado emocional, alguns olhavam preocupados, outros procuravam acalmá-la. Enquanto acontecia a cena, a equipe entrevistava as pessoas que estavam por perto. Quando indagados sobre o que estavam acontecendo, alguns diziam que "não sabiam de nada, estavam apenas esperando o seu transporte", outros afirmam ser um problema de ordem espiritual.

"Leve para o hospital psiquiátrico mais próximo", "chame a polícia" também foram algumas recomendações ouvidas neste episódio. Várias pessoas se mobilizaram, acreditando se tratar de uma situação real de surto do tipo psicótico. Em vez de encaminhar para uma possível internação, algumas perguntaram sobre o número da família para entrar em contato. Um vídeo que, a partir de um roteiro simples, retrata a complexidade de uma sociedade que oscila entre a solidariedade e o individualismo, entre o desejo de ajudar e a pressa do cotidiano de cada um.

Sem apresentar uma resposta única sobre qual encaminhamento apropriado a alguém que está numa situação de crise, é possível supor que essa falta de um direcionamento é reflexo de um quadro de desinformação generalizada sobre o tema da saúde mental. "O manicômio é bom porque lá ele é bem tratado" é uma fala que representa o desconhecimento da população sobre a realidade dos nossos serviços.

Diante de tantos encaminhamentos e recomendações apresentadas pelos passantes da rodoviária, o vídeo sempre provoca riso na público, especialmente dos universitários. Mas vale lembrar que, mesmo nas universidades, o imaginário social 
sobre a loucura ainda é perpassado por esses mesmos temas, muitas vezes carregados por crenças e atitudes de segregação. Talvez a resposta a este encaminhamento passe por essas questões religiosas, de polícia, de tratamento manicomial, mas, ao mesmo tempo, está além de todas elas.

\section{Vizinhos do Barulho (2008)}

No setor comercial de Brasília, entre os gritos dos feirantes e no meio do fluxo intenso de pedestres, começa uma cena. Três vizinhos discutem sobre um tema típico nas assembléias dos prédios: o barulho. A conversa começa com num tom de fofoca, "Você viu o barulhão que a vizinha do 302 fez ontem? Dessa vez veio parar até ambulância aqui!". A reclamação referia-se às frequentes crises de uma moradora que impedia que os outros moradores dormissem. Um dos moradores, argumenta que já estava esgotado, pois precisa se levantar bem cedo para seu trabalho e sentia seu sono prejudicado em função do tumulto. Entretanto, outra moradora lembra que, no mesmo prédio, também havia um barulho que incomodava muito mais, como as festas realizadas semanalmente no salão de festas do prédio.

A moradora questiona: "qual é a diferença do seu barulho para o barulho dela?". Na presença da câmera, alguns curiosos se aproximam para assistir a discussão dos vizinhos que se tornava mais fervorosa. O morador defendia que seu barulho não incomodava porque as pessoas gostavam da festa que ele fazia, todos saíam satisfeitos, além do mais, estava pagando pelo aluguel do salão. A discussão familiar a todos faz com que algumas pessoas que apenas observavam a cena também se envolvessem no drama. A equipe da tv pergunta o que seria possível para resolver a questão do barulho. Religião, livros de auto-ajuda, problemas de estresse, manicômio, todos esses elementos aparecem misturados às falas das pessoas entrevistadas.

A questão que se lê nas entrelinhas dessa produção é pensar a comunidade como um conjunto de pessoas que habitam um mesmo espaço, onde todos devem respeitar as mesmas regras de convívio. Não há como expulsar " os barulhentos" do prédio, afinal, eles também tem o direito de morar ali. Não há como excluir aqueles que incomodam, pois eles também tem o direito de viver. Assim, como numa grande assembléia, é preciso encontrar caminhos alternativos para construir uma convivência mais harmoniosa com os nossos vizinhos. 


\section{Efeitos Colaterais: Um Dia no Mundo dos Remédios (2008)}

O vídeo produzido em parceria com a Inverso trata o tema da hipermedicalização da vida com seriedade e bom humor, simultaneamente. O roteiro se apoia na representação do cotidiano e as dificuldades enfrentadas por aqueles que sentem os efeitos colaterais provocados pelos remédios psiquiátricos. O vídeo apresenta uma história cômica ficcional, além de depoimentos singulares de pessoas que fazem uso dessas substâncias. Para não reduzir a complexidade da temática, são apresentadas diferentes experiências em relação à medicação, desde os desafios em acordar com o psiquiatra uma dosagem adequada, até o manejo de seus efeitos.

O público que assiste Efeitos Colaterais: Um Dia no Mundo dos Remédios sempre se surpreende com algumas cenas que trazem a marca da qualidade criativa e crítica da proposta do vídeo. Entre elas, o peculiar relógio de pulso do protagonista: feito de papelão e caixas de medicamentos psiquiátricos, tem os números das horas substituídos pelos "tarjas pretas". O seu marcador não aponta mais para o tempo como o regulador da vida, mas a vida regulada pela medicação. Ao passante que the pergunta a hora, lê-se: são dez para Rivotril. Na hora do almoço, nosso protagonista vai até um self-service com um variado cardápio de cápsulas e comprimidos de todas as cores. Para finalizar, de sobremesa, mais efeitos colaterais. O relógio, desenhado pelo Carlos Augusto Vasconcellos, frequentador da Inverso, virou o símbolo do vídeo e foi utilizado no cartaz de divulgação do filme num evento realizado no Museu da República aberto a toda a comunidade.

Outro quadro bastante simbólico é a encenação de um atendimento psiquiátrico padrão. O ator que encarna a figura do médico conhece bem o papel que interpreta. A atuação baseada em sua experiência viva traz elementos autênticos e familiares a todos aqueles que já enfrentaram as demoradas filas para um curtíssimo atendimento. Certamente quem já passou pelo sofrimento e esteve em busca de cuidado, sabe reproduzir com muito mais sensibilidade todos os maneirismos automatizados de um profissional descompromissado. Em cena, o sujeito-ator veste "o sagrado jaleco branco" e denuncia ao espectador o que o usuário de saúde mental costuma observar nesses serviços: uma consulta cronometrada, despersonalizada e desumanizada. Ainda na sequência da representação, no canto da sala à direita do médico, há uma presença sutil de um personagem importante: o laboratório. Após os poucos minutos de conversa, um gigantesco número de receitas são prescritas e várias 
sacolas de medicamentos são entregues ao protagonista. Ao final da consulta, diante do lucro da indústria farmacêutica, o laboratório regozija-se e revela um sorriso irônico.

Remédios para acordar e para dormir, para controlar a euforia e a tristeza, para frear as paixões e inibir a dor. Sonolência, insônia, aumento de peso, impotência, diabetes são alguns dos efeitos colaterais comuns entre os remédios psiquiátricos, muitas vezes prescritos indiscriminadamente. O vídeo além de propor uma reflexão sobre os interesses capitalistas que (des)orientam nosso sistema de saúde, também apresenta os efeitos da medicalização da vida, compartilhando histórias reais de pessoas como eu e você.

\section{Me escuta, Brasília (2010)}

Em 30 de setembro de 2009 cerca de 2.300 pessoas marcharam em Brasília por uma Reforma Psiquiátrica Antimanicomial. Movimentos sociais integrados por usuários de saúde mental, familiares, simpatizantes e profissionais da saúde se uniram por uma extensa a pauta de reivindicações que vem sendo ignoradas no campo das políticas públicas: participação na vida social e trabalho, criação de moradias e de projetos culturais, ampliação do número de usuários do Programa de Volta para Casa, programas de capacitação para os profissionais da área de saúde, a garantia de implantação de ações de apoio no atendimento do usuário de saúde mental como a atenção à crise nos serviços abertos, a ampliação da rede de atenção 24 horas, o urgente fechamento de leitos em hospitais psiquiátricos, entre tantas outras solicitações encaminhadas aos Ministérios da União. (Conselho Federal de Psicologia, 2010)

A Marcha dos Usuários pela Reforma Psiquiátrica Antimanicomial representou a construção de um grande coletivo nacional que incluiu a participação dos usuários no poder público. De diferentes estados do Brasil, todos se reuniram em Brasília para protagonizar sua cidadania, discutindo as necessidades de uma política nacional de saúde mental intersetorial e integral.

São eles os usuários que podem trazer com clareza, na memória dos seus corpos e almas, quais são as necessidades vividas no cotidiano, quais são as suas urgências e preferências. Que a sua voz possa ser adequadamente ouvida em 
todas as conferências municipais, estaduais e nacional, de forma livre, sem tutelas, mas com o apoio solidário de todos os militantes antimanicomiais. (Rede Nacional Internúcleos da Luta Antimanicomial - RENILA em Conselho Federal de Psicologia, 2010)

Para escutar todas essas vozes, a Tv Sã confecionou dois "orelhões" para a repórter usar enquanto brincava com seus entrevistados: "Essa orelha grande é do lobo bom, não é do lobo mal não, viu?". Contando ainda com uma numerosa equipe de estudantes na produção do vídeo, foi possível acompanhar o evento durante o dia inteiro, coletando vários relatos breves, desde experiências positivas de diversos CAPS a inexistência de serviços a certos grupos populacionais, alguns cantaram músicas em homenagem ao serviço, outros se emocionaram ao pedir por mais humanização. Todos marcharam pela saúde mental e gritaram "Me escuta, Brasília".

Esse ato político culminou na IV Conferência Nacional de Saúde Mental, passados oito anos da III Conferência e da aprovação da Lei 10.2016/01. Esse evento representou uma importante avaliação da política de saúde mental e das políticas a ela intersetoriais. Ainda que essas reinvindicações não tenham sido atendidas, sem dúvida foi um momento histórico na históra da saúde mental no Brasil, apresentado inclusive nas mídias tradicionais. A Tv Sã não só teve o privilégio de registrar esse momento, mas também de participar e protagonizar com toda a equipe de estudantes, profissionais, e principalmente usuários, seu próprio olhar sobre a Marcha.

\section{Tudo acontece em família (2015)}

No debate realizado após a exibição do vídeo Efeitos Colaterais no Museu da República, uma pessoa conta um relato emocionado sobre a experiência de ser mãe de uma pessoa com uma diagnóstico psiquiátrico. "É aquela velha história: a gente casa, tem um filho, não imagina que ele vai ter um problema, mas a vida vai nos ensinando...", assim ela inicia sua reflexão sobre as dificuldades do cuidar. Esse momento, que provavelmente tocou outros familiares presentes, serviu de inspiração para a construção de um vídeo que abordaria um tema tão complexo, especialmente para a saúde mental: a família.

O roteiro coletivo desse projeto foi construído a partir de histórias comuns vividas em hospitais e clínicas psiquiátricas, mas que teve como aspecto diferencial a participação ativa de familiares. Não seria coerente falar sobre a importância da 
família sem incluí-la efetivamente nessa produção. Sendo assim, a Tv Sã criou uma narrativa entre a ficção e a realidade, combinando elementos de drama, suspense e comédia, intercalados por depoimentos de profissionais e outros familiares. O vídeo contou com a participação de mãe e filho que encenaram parte de suas histórias, dramatizadas na mesma casa e cômodo em que a primeira crise aconteceu. Mesmo tendo uma conversa anterior com os futuros atores desta produção, as filmagens foram conduzidas de forma cuidadosa e leve para não desencadear emoções fortes sobre o episódio, já que esse não era o objetivo.

O vídeo inicia com uma cena comum ao universo lúdico-infantil: na loja de brinquedos uma criança é incentivada a comprar "os bonecos do ano". De cabelos longos e loiros, com pele clara e olhos azuis, a barbie vinha acompanhada com seu "par ideal" numa mesma caixa onde se lia "perfeição". A valorização do padrão estético da boneca é anunciada pelo comerciante que felicita a família pela sua compra. Em casa, a criança - sempre observada pela mãe - começa a experimentar outras combinações de casais. Mesmo ocupada com as tarefas domésticas, "os desvios" não passavam despercebidos e, insistentemente, a mãe corrigia sua filha a cada arranjo que não correspondia ao modelo da caixa: "Essa não é par para ele, veja como é pobrinha", "essa não pode porque está faltando perna", "brinque com o casal certo". Com o tempo, a criança abre mão de suas descobertas para atender os desejos da mãe, aprende que há um modelo a ser seguido e que toda a transgressora manifestação da diversidade estaria categorizada como erro. Assim cresce essa criança com um modelo de referência idealizado e empobrecido.

Ao tornar-se mãe, se depara com uma realidade distinta. O mesmo modelo de perfeição consumido durante toda a sua vida, se mostra fragilizado quando seu filho entra em crise. Na sala de tv, entre alucinações e delírios, a família se sente completamente perdida naquela situação de instabilidade. Na busca por uma solução imediata, a mãe chama a ambulância, acompanha seu filho até o hospital psiquiátrico, mas é orientada a deixá-lo só, sob os "cuidados médicos"23. Contrariado, o novo paciente tem suas mão atadas e amarrado a um CID que passa a justificar todas as suas ações cotidianas. De volta para casa, o saber psiquiátrico invade a vida familiar:

\footnotetext{
23 "As instituições totais são também incompatíveis coro outro elemento decisivo de nossa sociedade: a familia." (Goffman, 1974, p.22)
} 
seu nome passa a ser "CID-7020".

Na busca de alternativas mais humanizadas, a mãe começa a acompanhar seu filho numa instituição de saúde mental que supostamente apresentava uma proposta alternativa. Mesmo ali, a mãe observava a falta de um acompanhamento singularizado, já que a equipe, visivelmente departamentalizada, sabia muito pouco sobre seu "cliente" e não conseguia alcançar nenhuma melhora qualitativa na vida dele. A postura denunciativa da mãe provocou um grande incômodo nos profissionais que reagiam de forma defensiva: "Você está muito ansiosa, quer um remediozinho?" ou "Você está esperando muito dele, precisa ter paciência". Diante do fracasso dos serviços e do discurso médico reducionista, vem a reviravolta dessa história. De mãos dadas com o seu filho, a mãe diz: "De agora em diante, você é o Rodrigo".

Reconhecer todo o potencial do sujeito sem limitá-lo ao diagnóstico é um grande desafio para a família que foi historicamente excluída do cuidado no processo de enclausuramente da loucura. $\mathrm{O}$ saber psiquiátrico escuta muito pouco sobre o que a família observa em relação aos efeitos de cada medicação no cotidiano do paciente, sobre as estratégias mais criativas que eles encontram para resolver situações de crise, e tantas outras experiências positivas descobertas com a família. Retomá-la como parceira igualmente importante nesse processo é fundamental para o reestabelecimento do sujeito, não só por ela representar a primeira referência do mundo simbólico e social do sujeito, mas também porque toda família precisa igualmente de cuidados, só assim é possível torná-la melhor cuidadora.

Esse vídeo foi exibido em eventos de saúde mental e universidades, mas o local que teve uma repercussão mais intensa foi na assembléia do CAPS - Taguatinga que reunia familiares e usuários de saúde mental. De forma surpreendente, muitos se comoveram com as cenas iniciais do vídeo da criança e sua liberdade podada, despertando reflexões sobre suas próprias histórias. As representações sobre a internação também foram assistidas atentamente por todos. "É exatamente isso que acontece lá dentro, foi isso que eu vivi", comentou um usuário de saúde mental.

Nas duras críticas direcionadas aos serviços ditos alternativos, a equipe se sentia numa posição desconfortável. Mesmo assim, após a apresentação do vídeo, muitos depoimentos, com um forte teor religioso, surgiam em agradecimento à caridosa assistência oferecida pelo CAPS. O mais interessante foi observar a 
mobilização que vídeo provocou na assembléia, fazendo com que muitas pessoas falassem sobre suas histórias e revelassem várias demandas urgentes que estavam aguardando apenas um estímulo para se pronunciarem.

\subsection{5 - O processo de construção de um vídeo}

Em todas essas produções citadas, o grupo construiu uma dinâmica própria de construção de vídeos e estabeleceu etapas que deram a base para o processo criativo acontecer. Do mesmo modo que os manuais psiquiátricos foram deixados de lado, tais etapas de construção do vídeo também não têm a pretensão de seguir a risca os manuais da comunicação. Trata-se de um saber moldado e enriquecido a cada novo projeto coletivo, capaz de se reinventar a partir das experiências com a comunidade. As etapas podem ser dividas em:

a) Roteiro coletivo: $O$ grupo define uma temática específica a ser trabalhada a partir das necessidades da comunidade, de uma instituição ou de um grupo de pessoas. $\mathrm{Na}$ fase inicial dessa etapa é feito um brainstormming, ou seja, todos os participantes expõem livremente ideias sobre temas que merecem ser trabalhados, cenas específicas que poderiam ser retratadas ou aspectos gerais sobre a produção. Algumas perguntas servem para nortear o trabalho e delinear o que se pretende fazer, como por exemplo: O que se pretende filmar? O filme está direcionado para qual público? Qual o objetivo? Que tipo de estrutura narrativa será utilizada? Que cenas, personagens e situações devem ser mostradas? A partir dos elementos trazidos pelo grupo, as cenas começam a ser organizadas em uma ordem temporal, podendo ser reposicionadas conforme o aparecimento de novas ideias. $\mathrm{O}$ roteiro deve ser registrado por escrito como guia para as etapas seguintes. Pode ser inspirado a partir de um projeto de vídeo imaginado por um único participante ou mesmo à convite de uma instituição, a decisão fica a critério do grupo. $\mathrm{O}$ caráter principal do processo é o incentivo à participação de todos para que a produção seja efetivamente coletiva. A construção do roteiro é um momento único que pode ser realizado em mais de um encontro. Nas reuniões, o grupo se conhece melhor através do exercício de escuta do outro, o compartilhamento de histórias de vidas parece surgir naturalmente e diferentes relatos são transformados em uma narrativa comum a todos. Os fragmentos de discursos são reorganizados numa nova temporalidade e a linguagem dissociada transforma-se em linguagem cinematográfica. As vivências comuns propiciam um processo de 
identificação entre os membros do grupo que podem manifestar suas opiniões, representações, sentimentos e percepções. A noção de pertencimento de grupo facilita o restabelecimento do elo social perdido, além de favorecer a circulação da informação. Os relatos podem atuar na prevenção de possíveis situações de controle, intimidação, discriminação que passam a ser reconhecidas pelo sujeito como expressões de violência.

b) Produção: A parte logística da produção bem realizada é fundamental para a qualidade do filme. A equipe de produção deve estar empenhada na organização antes, durante e depois das filmagens. A coleta dos termos de consentimento de uso da imagem dos atores, a autorização para gravar em determinados ambientes, o planejamento dos cenários, dos figurinos, o agendamento dos dias de filmagem levando em consideração as condições climáticas são algumas das tarefas dos responsáveis pela produção. Uma equipe de produção atenta durante a filmagem pode ser determinante no aproveitamento das imagens durante a edição. Organizar eventos é um talento a ser desenvolvido por todos, exige sintonia no trabalho em equipe e capacidade de divisão do tempo. É mais que um ajuste de todas as agendas, a responsabilidade de estar na produção implica numa relação de confiança e reciprocidade com o outro e com o grupo. É etapa em que o trabalho coletivo ganha força total, quanto melhor a comunicação entre os produtores, mais imprevistos são evitados ao longo do trabalho.

c) Filmagem: Enquadres por planos, posição das câmeras e perspectiva da imagem, manejar contrastes claros e escuros, são algumas noções necessárias para essa etapa. A Tv Sã já contou com a participação de alguns técnicos que fizeram as filmagens para o grupo. Contar com a ajuda profissional tem um valor muito maior que a utilização mais precisa dos equipamentos. Através da participação desses técnicos o tema da loucura é, pela primeira vez, apresentado a partir de uma ótica desestigmatizante. Não são raras as vezes em que os técnicos de filmagem ou edição passam a sentir-se à vontade em compartilhar histórias entre as gravações, são histórias de um amigo "meio pirado", de um tio distante que "endoidou" ou até de um familiar próximo. Ao ver a loucura através do visor da filmadora, é possível enxergar um novo universo e compreender que ele desde sempre fez e faz parte do mundo em que vivemos. Quando a filmagem está sob responsabilidade de um usuário de saúde 
mental também há vantagens. Ele não só já conhece o roteiro coletivo, mas entende a história-viva que ele representa. O operador da câmera deve não só encontrar os melhores ângulos, mas também ter sensibilidade quantos aos enfoques, quando mover a câmera, o corte e a altura em que a cena é filmada, pensando na experiência do expectador ao assistir o filme. $\mathrm{O}$ observador externo da cena que registra a história narrada deve estar aberto a se identificar com ela, deve estar predisposto a se ver e se representar em captura de imagens. É um exercício de observação, identificação e representação.

d) Atuação: Se na construção do roteiro a experiência vivida pelo sujeito se transforma em texto; na atuação, o texto se enche de vida e é ressignificado pelo corpo. Muitas vezes os efeitos da supermedicalização e a objetificação dos sujeitos confinam o corpo à inércia e à passividade e é a atuação que convida o sujeito a movimentar-se, a explorar toda a sua capacidade de ação pela representação. Desse modo, essa etapa não representa apenas o deslocamento da linguagem textual em corporal, mas marca o desenvolvimento histórico autoconsciente daqueles que atuam. A linguagem, enquanto processo simbólico social permite reorganizar a percepção de si no mundo no seio de um projeto existencial. Significa dizer que, quando há encenação de uma experiência já vivida, o sujeito que está em cena exercita o protagonismo - em todos os seus aspectos. Ver sua história materializada em narrativa coletiva e reinterpretá-la à sua maneira, torna mais concreta a possibilidade de ação efetiva sobre os próprios projetos de vida. Além disso, a interpretação de um papel permite ao ator refletir a partir de outras posições. O corpo sempre modelado pelo olhar censurador do outro, aqui ganha expressão. O paciente psiquiátrico veste $\mathrm{o}$ jaleco e nos revela: na sociedade de controle, em que todos os nossos atos estão sob constante suspeita de anormalidade, os padrões fixos de norma e de desvio podem se confundir quando há espaço para a livre manifestação da criatividade.

e) Edição: Corresponde a um dos momentos essenciais da construção do vídeo em que as imagens são reorganizadas, os tempos são modificados e uma infinidade de efeitos sonoros e visuais podem ser utilizadas para dar o toque estético e a identidade final do projeto. A expressividade e a criatividade são amplamente exploradas pra extrair todo o potencial do material bruto. É possível corrigir ruídos, incluir narrativas, fundo musical, títulos e créditos. Na parte inicial dessa etapa é realizada a 
découpage, geralmente realizada com todo o grupo, em que é decidido o que entra para o filme e o que é descartado. É o primeiro recorte para reduzir o material e prepará-lo para uma edição mais fina. Apesar de ser uma parte mais técnica, todos dão sugestões de transição de cenas e diferentes montagens. Assim como na filmagem, a utilização dos recursos do programa de edição envolve aprendizado, mas ainda que apenas uma pessoa domine as técnicas, o consenso do grupo sobre a construção do vídeo permanece sendo a chave-mestre.

f) Divulgação: A divulgação é um momento de celebração de um projeto finalizado, é o resultado final de todo um esforço coletivo. Quando o vídeo é exibido pela primeira vez publicamente, é contagiante o orgulho de todos que participaram. Os amigos convidados também exibem sua alegria em ver os atores da Tv Sã no telão do auditório. Amizades que muitas vezes se construíram no interior de uma instituição de saúde mental, espaço compartilhado pela condição de sofrimento, experimentam nessa etapa um novo sentimento, fora dos muros podem confraternizar suas alegrias e compartilhar esperanças. A divulgação tem como objetivo fazer o encerramento formal de um projeto, tornar conhecida a oficina de vídeos e os demais trabalho do grupo, apresentar à sociedade a loucura sob uma ótica desestigmatizante, e por último, mas não menos importante, ocupar a cidade.

É importante lembrar que as etapas descritas servem para orientar o trabalho, mas não devem estar restritas à sua obediência. Produzir um vídeo sob a lógica antimanicomial é desfazer-se da amarras da burocracia, da automatização, sem abrir do valor estético das produções audiovisuais. Na criação dos vídeos, todo o processo é marcado pelo fazer coletivo, pelo exercício da tolerância, do respeito, em que todos assumem responsabilidades e descobrem habilidades. Ainda que as oficinas não tenham um cunho terapêutico, em seu sentido estrito, a qualidade das relações dos participantes do grupo entre si amplia-se para as demais relações sociais estabelecidas fora do grupo. Apesar da rara participação de familiares de usuários em saúde mental nas oficinas, as mudanças podem acontecer indiretamente quando os conflitos relacionais são amenizados pelo reconhecimento da sua atividade artística-cultural.

A mudança é percebida não só na vida daqueles que estão em sofrimento intenso. A Tv Sã já foi para alguns estudantes de psicologia o primeiro contato com a saúde mental. Pela convivência, os alunos foram despindo-se de seus próprios 
preconceitos e ampliando suas trocas simbólicas em direção a uma atuação profissional mais ética. A cada reunião do grupo, pelo encontro de alteridades, a loucura foi pouco a pouco sendo desmitificada. Os receios quanto a periculosidade ou incapacidade se mostravam cada vez mais descabidos à medida que o sofrimento era entendido como um fenômeno complexo, fundamentalmente humano, em que todos são potencialmente capazes de vivenciá-lo em diferentes intensidades. 


\section{CAPÍTULO IV - PARA DESBRAVAR NOVOS CAMINHOS}

\section{1 - Aspectos éticos e metodológicos da pesquisa}

O conhecimento não deve ser concebido como uma revelação da realidade, mas como uma construção de espaços de inteligibilidade sobre sistemas. No entanto, superar algumas as noções de objetividade, neutralidade e causalidade presentes na ciência, parece não ter sido suficiente para libertar o pensamento psicológico ainda dominado pelo paradigma da simplicidade que sustenta princípios isomórficos herdados de um modelo positivista que rejeita outras inteligibilidades que destoam dos parâmetros laboratoriais. O status de reconhecimento e de confiabilidade parece ainda estar restrito ao campo das ciências duras, provocando um incômodo às ciências humanas e sociais. (Neubern, 2001). Em resumo, vemos que o paradigma científico dominante ainda possui fortes raízes na modernidade/colonialidade.

A fim de romper com esse imperialismo epistêmico, parto de que a verdade absoluta jamais será conhecida, pois todo processo de conhecimento nos leva a um acesso sempre parcial, limitado e guiado pelas nossas práticas. (Morin, 1999) "Deste modo, quando eu digo ciência, eu não estou dizendo verdade, estou simplesmente dizendo processo: a ciência é um processo de produção do conhecimento da verdade" (Löwy, 1991, p. 110). González Rey (2005), de modo semelhante, afirma que a pesquisa é um processo de comunicação, um processo dialógico construtivointerpretativo. Nessa perspectiva, assumir a dimensão humana da produção do conhecimento é reconhecer a realidade como um domínio infinito, e não como um sistema externo.

A pesquisa é um processo de comunicação que se organiza progressivamente e que permite e estimula a expressão dos sujeitos por meio do lugar por eles ocupado em tal processo e também por vias mais significativas para ele(a), as quais vão sendo conhecidas no curso da própria pesquisa (González Rey, 2005. p.42).

Löwy (1991), em sua obra Ideologias e Ciência Social, traz importantes reflexões e críticas sobre as questões que perpassam a relação ciência e ideologia. Numa perspectiva marxista, o autor aponta que as ideologias não são idéias isoladas, mas um conjunto orgânico, uma superestrutura criada pelas classes, entretanto, destaca que não podemos nos deixar ser levados por um "reducionismo sociológico", 
reduzindo toda produção científica à posição social. Além disso, não é aconselhável essencializar o ponto de vista de uma categoria, já que esta também recebe influências externas. Seguindo a proposta de Löwy (1991), adotar o ponto de vista de determinada classe corresponde à tomada de consciência de interesses históricos. Significa dizer que, para representar determinado grupo não preciso, necessariamente, compartilhar as mesmas experiências, mas ter consciência das políticas de conhecimento as quais eu me vinculo enquanto pesquisadora.

Sem dúvida, o campo científico é um campo em disputa. Se sabemos que teorias não refletem a natureza humana, mas sim, a ideologia daqueles que a criaram, se sabemos que não há uma separação clara entre "ciência pura" e ideologia, torna-se, então, imprescindível uma vigilância epistemológica constante para ampliar nosso horizonte intelectual, reconhecendo os próprios limites de nossa ideologia. É necessário policiar nossos desejos de controle com o campo estudado, para que os fenômenos possam surgir a partir de sua própria lógica. Abandonar essas forças colonizadoras não é uma tarefa fácil, implica um olhar atento sobre as referências da relação eu-mundo, tanto do sujeito, quanto do próprio pesquisador.

A reflexividade é um recurso fundamental para que tais relações sejam mapeadas. Esse princípio é o elemento que acrescenta o teor ético à pesquisa, indicando que toda informação é proveniente de processos sujetivos. Assim, o processo de pesquisa deve reconhecer os contextos e as subjetividades, deve admitir o caráter relacional e romper com a separação sujeito-objeto. O pesquisador deve constantemente questionar a si mesmo em termos teóricos e sócio-culturais para reconhecer que também é atravessado pela subjetividade do pesquisado. Dessa forma, a realidade aqui estudada é um recorte social específico, condicionado pelo momento histórico, pelo lugar e pela organização econômica.

A metodologia da pesquisa é, portanto, um regime de verdade de produção de conhecimento. Pode servir como um importante instrumento de poder e de contra hegemonia com potencial para evitar as consequências mutiladoras, reducionistas e unidimensionais de um pensamento simplificador. Tem como objetivo abrir novas possibilidades para estudar espaços de inteligibilidade fundamentando-se em construções teóricas que possam ser posteriormente articuladas em modelos cada vez mais úteis para gerar novos conhecimentos e reconhecimentos de sujeitos até então invisíveis ou estigmatizados. 
À luz dessas considerações, gostaria de esclarecer meu papel enquanto pesquisadora. Em termos etnográficos, meu trabalho de campo na saúde mental, mais especificamente na Tv Sã, iniciou-se em 2009, no contexto de um projeto de extensão da graduação em Psicologia. Mesmo formada, segui no grupo, observando, registrando, participando e sentindo. Tal como a "perspectiva da antropologia fenomenológica enfatiza o envolvimento corporal do etnógrafo no mundo do nativo, um mergulho a um só tempo sensorial, motor, afetivo e cognitivo" (Bizerril Neto, 2004, p. 155), também me deixei afetar para entrar em contato com esse universo. Aprendi a "fazer com" e ensinei outros a fazerem conosco. Posso dizer que a construção desse vínculo afetivo foi indispensável na construção dessa pesquisa qualitativa. Sendo assim, as análises apresentadas nessa pesquisa não se referem apenas ao dados coletados no momento da entrevista, mas implica uma percepção construída a partir de uma relação estreita e cotidiana. Do mesmo modo ocorre no campo da antropologia, sem o estabelecimento de uma aliança, pacto ou relação de cooperação e confiança entre o etnógrafo e seus colaboradores nativos é impossível fazer pesquisa. A essa relação de reciprocidade pautada nas ligações emocionais, Bizerril denominou "vínculo etnográfico".

Nessa perspectiva, a figura do pesquisador como um observador externo se desfaz quando é posto em evidência o valor dos processos subjetivos na produção das experiências humanas, levando em consideração as emoções e os processos simbólicos como parte de um mesmo sistema. É preciso que o pesquisador possua uma boa capacidade de escuta e observação, que esteja familiarizado com as teorias relevantes à pesquisa, mas, principalmente, tenha capacidade de estabelecer ligações emocionais e relações de reciprocidade. Algumas vezes tais relações ultrapassam a situação de campo e seguem como amizades. (Bizerril Neto, 2004)

Durante esse percurso de quase seis anos na Tv Sã, ficou claro que é exatamente a importância dada às relações humanas que favoreceu a emergência do sujeito, fazendo com que ele se pronuncie sobre a sua validade. O cuidado em falar com e não falar por marca a diferença fundamental entre a pesquisa que busca colonizar e a que busca compreender. Por esse motivo, escolhi a metodologia do Discurso do Sujeito Coletivo como ferramenta de caráter interativo que instiga essa expressão, sem preestabelecer qualquer sistema de categorias para atribui-lhe significado. Com o objetivo de evitar qualquer epistemicídio (assassinato do 
conhecimento do outro), esse método nos ajuda a perguntar melhor, pois nós não podemos afirmar nada pelos outros, mas com os outros.

Devo dizer ainda que minha participação ao longo desses anos também me transformou profundamente. $\mathrm{O}$ confronto com o universo da diferença e a abertura a esse novo mundo extraordinário ocultado pelos modelos convencionais produz reflexões não só sobre o Outro, mas sobre o si-mesmo-como-um-outro. Dada essa permeabilidade, afirmou Bizerril (2004) "não é possível abrir-se a outro mundo cultural e voltar totalmente incólume" (p. 60).

Diante do exposto e utilizando a reflexividade, assumo a minha dimensão humana como parte integrante do processo de conhecimento. Se por um lado o vínculo estabelecido com o grupo agregou valor qualitativo à pesquisa e envolveu as pessoas emocionalmente facilitando o aparecimento dos sentidos subjetivos; por outro lado, enquanto participante do grupo, torna-se mais difícil analisar criticamente tais expressões simbólicas, tanto por conhecê-las no contexto específico da história de cada indíviduo e de seus familiares, como também na relação intersubjetiva estabelecida comigo como membro do grupo.

Seguindo minha postura ética-epistemológica defendida ao longo desse trabalho, cabe assumir todos os sentidos de pathos envolvidos nessa pesquisa e darlhes o devido tratamento teórico. Em razão de eu ser um dos membros mais antigos, é fácil perceber um forte sentimento de pertencimento à Tv Sã e, talvez, uma sensação de responsabilidade com o grupo, pois percebo que essa pesquisa é também um trabalho de co-autoria com esse coletivo. Devido a essa relação de carinho e graditão que coexiste na figura da pesquisadora/participante, torna-se incoerente assumir uma posição clássica de distanciamento científico. Não nego que minha paixão e minhas expectativas no crescimento desse projeto sobrevoam esse estudo, mas não deixo que minha escrita as imprima sem nenhum filtro.

Sendo assim, o mais apropriado nesta situação de pesquisa é realizar uma "negociação entre a necessária cientificidade do trabalho e a indispensável responsabilidade ética e política" (Bizerril Neto, 2004, p. 157). Levando isso em consideração, a relação pesquisadora/participante/militante não assume necessariamente uma posição de contrariedade, mas de complementariedade. É exatamente o fato de reconhecer essas diferentes posições que ocupo enquanto pesquisadora que torna essa negociação mais clara. 


\section{2 - Discurso do Sujeito Coletivo}

Ainda pemanece no imaginário científico alguns argumentos que privilegiam o uso de instrumentos quantitativos, dentre eles, destaca-se: qualquer tipo de pesquisa empírica evolve generalizações e que não é possível generalizar sem quantificar; pesquisas que investigam o pensamento de uma coletividade (como é o caso) devem ser primeiramente transformadas num objeto quantificável; a melhor alternativa é a aplicação de questionários fechados, com alternativas de resposta. Mesmo que tais argumentos persistam, fica evidente que as pesquisas empíricas apenas quantitativas não são adequadas para lidar com objetos de natureza discursiva, como o pensamento, as crenças, as representações. (Lefèvre, Lefèvre, \& Marques, 2009)

Sendo assim, para analisar a expressão do pensamento coletivo sob forma de discursos coletivos, a metodologia que melhor preenche essas lacunas epistemológicas é a abordagem qualitativa. Por isso, a proposta do Discurso do Sujeito Coletivo (DSC) de reunir distintos discursos ou pensamentos de conjuntos de indivíduos em uma única categoria se mostra como a opção mais adequada para essa pesquisa. O fator determinante na escolha do DSC como instrumento é a sua qualidade operacional que, mesmo com o processo de categorização, não deixa de lado o caráter intrinsecamente discurso do pensamento.

O DSC é uma ferramenta útil para que o pensamento coletivo se expresse, é uma técnica que processa, reune e analisa depoimentos sob a forma de um único discurso, redigido na primeira pessoa. Baseia-se na organização e tabulação de dados qualitativos de natureza verbal coletados a partir dos depoimentos, extraindo-se deles suas ideias centrais. Essa técnica qualiquantitativa, inspirada pelos fundamentos da teoria da Representação Social, foi desenvolvida por pesquisadores da USP, consolidada no final dos anos 90 e hoje é amplamente utilizada em pesquisas sociais empíricas. (Lefèvre et al., 2009)

O DSC utiliza as seguintes figuras metodológicas:

a) Expressões chave $(\mathrm{ECH})$ : trechos ou transcrições literais de cada resposta que devem ser destacados pela sua importância de conteúdo das representações.

b) Ideias Centrais (IC): expressão que revela de maneira mais sintética e precisa o sentido de uma resposta. Cada resposta pode apresentar mais de uma ideia central. 
c) Ancoragem (AC): Algumas expressões chave $(\mathrm{ECH})$ não remetem exatamente a uma ideia central (IC) correspondente. A AC é a expressão explícita de uma dada teoria, ou ideologia, ou crença que o autor do discurso utiliza para "enquadrar" uma situação específica.

Resumidamente, a proposta do DSC é produzir um discurso síntese, ou seja, reconstituir de uma entidade empírica coletiva na forma de um sujeito de discurso, respeitando a dupla condição qualitativa (enquanto representação de um conteúdo ampliado e diversificado) e quantitativa (número representativo de indivíduos). Desse modo, o discurso do sujeito coletivo se organiza na primeira pessoa compatível com o regime natural das representações sociais ${ }^{24}$ em que os sujeitos opinam e expressam suas crenças individualmente. É importante esclarecer que "os DSCs, portanto, não são as representações sociais, mas buscam apenas constituir uma camada delas" (Lefèvre \& Lefèvre, 2006, p. 52)

Para que a opinião coletiva seja reconstituída artificialmente e convertida em um objeto qualitativo, será fundamental utilizar os construtos metodológicos adequados. Sendo assim, os dados qualitativos serão organizados através de uma técnica de tabulação que permite sistematizar os depoimentos sem reduzi-los. Entretanto, há de se considerar que qualquer pensamento coletivo sob forma de um discurso é um constructo que implica algum artificialismo.

Mas este necessário artificialismo é, sem dúvida, bem menos artificial que aquele presente nas pesquisas tradicionais, de corte quantitativo, onde os pensamentos dos indivíduos são, desde o início do processo de pesquisa, profundamente violentados em sua natureza discursa (e, portanto qualitativa) quando apresentados pelo pesquisar ao pesquisado. (apresentação do DSC no Qualiquantisoft)

Desse modo, construir o DSC não corresponde a uma mera soma dos pensamentos dos participantes. Nesse sentido, o software Qualiquantisoft serve para

\footnotetext{
24 "As representações sociais são esquemas socio-cognitivos de que as pessoas lançam mão para emitirem, no cotidiano de suas vidas, juízos ou opiniões, que são condições necessárias para viver e se comunicar em sociedades complexas. Estes esquemas sociocognitivos, acessáveis através de depoimentos individuais, são entidades virtuais que, por isso, precisam ser reconstituídas através de pesquisas sociais que comportem uma dimensão qualitativa e quantitativa." (Lefèvre, Lefèvre e Marques, 2009, p.1196).
} 
ordenar as entrevistas e transformá-las em um único discurso síntese que possa ser estudado, ou seja, os pensamentos individuais são "coletivizados" soob uma forma qualitativa. A partir do material verbal apresentado pelos participantes, serão analisadas as idéias centrais ou ancoragens, indicando a densidade semântica nas representações sociais do grupo (Lefèvre \& Lefèvre, 2006).

\subsection{1 - O Software Qualiquantisoft}

O Qualiquantisoft é um facilitador de pesquisas qualitativas nas quais é utilizada a técnica do Discurso do Sujeito Coletivo. Trata-se de um recurso da informática que facilita principalmente as pesquisas que possuem uma grande massa de depoimentos, já que, com a ajuda do instrumento, o investigador pode economizar tempo e aumentar da eficácia da investigação, para dedicar-se à parte mais importante da pesquisa que é a detecção e análises dos sentidos das falas dos entrevistados.

Esse software trouxe um grande avanço nas pesquisas sociais pela sua capacidade de associar pensamento, crenças, representações a características como gênero, idade, escolaridade. Contudo, esse recurso não substitui o papel do pesquisador, tal como é mencionado na página de apresentação do programa "O Qualiquantisoft não faz nada pelo pesquisador, mas faz muita coisa para o pesquisador". O software permite arquivar dados e banco de dados relativos aos entrevistas, pesquisas, perguntas, além de imprimir os principais resultados das pesquisas para facilitar a visualização.

\section{3 - Condução da pesquisa}

Em relação aos aspectos éticos e concordância com a Resolução no 196/96 do Conselho Nacional de Saúde - CNS, que trata de diretrizes e normas regulamentadoras de pesquisas envolvendo seres humanos, o projeto desta pesquisa foi submetido à Plataforma Brasil e analisado pelo Comitê de Ética em Pesquisa do Instituto de Ciências Humanas da Universidade de Brasília - CEP/IH. O longo processo de análise do projeto envolveu a submissão de uma série de documentos que visaram resguardar os processos éticos da pesquisa: carta de revisão ética, aceite institucional da Inverso, carta de encaminhamento da pesquisadora, perguntas norteadoras e o Termo de Consentimento Livre e Esclarecido - TCLE. Para realizar a pesquisa, o TCLE foi lido e assinado por todos os participantes, garantindo-lhe a 
confidencialidade dos dados coletados, bem como o retorno dos resultados da pesquisa.

Algo que merece ser destacado durante esse processo é o fato dos participantes desejarem manter seus nomes próprios nesta pesquisa. Em função da postura clássica das pesquisas que preocupam-se em respeitar a privacidade de seus participantes, especialmente a importância dada ao sigilo no campo da psicologia, foi perguntado aos participantes se eles desejariam preservar suas identidades alterando seus nomes reais para nomes fictícios. Com exceção da mãe de um dos usuários, todos optaram por manter seus nomes. Conforme disse Elias: "Eu não sou uma ficção, minha história é real".

Esclarecido esse ponto, deu-se início à coleta de dados realizada por meio de um grupo focal. Os integrantes da $\mathrm{Tv}$ Sã foram entrevistados grupalmente promovendo um debate aberto e acessível sobre temáticas de interesse comum a todos. Ao final da entrevista, agradeci a presença de todos.

\section{4 - A entrevista qualitativa e o grupo focal}

A entrevista qualitativa é mais flexível, íntima e aberta. O início e o final não são predeterminados nem definidos claramente, do mesmo modo a ordem das perguntas não obedece uma sequência rígida, mas é adapatável à participação dos participantes. Assim, o ritmo e a direção da entrevista é compartilhado com o entrevistador. Procura-se estabelecer um caráter mais amistoso e elaborar perguntas mais neutras já que se pretende obter pontos de vista, experiências e opiniões detalhadas dos participantes em sua própria linguagem. (Sampiere, Collado, \& Lucio, 2013)

Os grupos focais são utilizados na pesquisa qualitativa em todos os campos do conhecimento e funcionam como uma espécie de entrevistas em grupo, geralmente composto por grupos pequenos ou médios ( 3 a 10 pessoas). $\mathrm{O}$ grupo focal incentiva a interação dos participantes através de um ambiente tranquilo e informal. A conversa sobre um ou vários temas deve conduzida por um especialista em dinâmicas de grupo que trabalhará as experiências, emoções, crenças, categorias, acontecimentos ou temas que interessam na formulação da pesquisa.

Essa forma de entrevista vai além da elaboração de perguntas aos vários participantes, pois o que se quer é gerar e analisar é a interação entre eles. A unidade 
de análise é o grupo, para tanto, é necessário estimular a participação de cada pessoa, evitar possíveis agressões. O roteiro de tópicos dos grupos focais pode facilitar o pesquisador a obter seus dados qualitativos. Ele pode se organizar de modo estruturado, semiestruturado ou aberto. (Sampiere et al., 2013)

Em um estudo dessa natureza, é possível ter um grupo em uma só sessão como foi o caso. Nessa pesquisa que contou com a participação de 6 integrantes, o roteiro de tópicos utilizado foi aberto, abrangendo os seguintes tópico norteadores:

- Analisar como são desenvolvidas as atividades pelo grupo;

- Compreender a importância da Tv Sã na vida dos participantes do projeto;

- Investigar os aspectos motivadores na entrada dos participantes neste projeto;

- Investigar os fatores que influenciam a permanência ou a saída dos participantes;

- Analisar como grupo Tv Sã percebe as relações que estabelece com outras instituições (família, serviços de saúde mental, ONGs e universidades).

De modo geral, o grupo focal foi bastante positivo tendo em vista que todos os membros participaram de maneira descontraída, sem que a discussão fosse direcionada por apenas um participante. As análises sobre a dinâmica do grupo e o conteúdo dos das entrevistas serão explorados no capítulo seguinte.

\section{5- Análise sobre a dinâmica da entrevista grupal}

Antes de analisar propriamente o Discurso do Sujeito Coletivo Tv Sã, considero válido apontar algumas situações e falas de alguns participantes. A entrevista realizada em julho contou com a participação de seis integrantes: Fabiana, recém-formada em psicologia; Elias e Léo, usuários de saúde mental da rede pública; Rodrigo e Henrique, da rede privada; e Maria, familiar. $\mathrm{O}$ grupo focal teve início às 15h30, conforme informado por telefone aos participantes, e teve duração de aproximadamente duas horas e meia.

Maria, mãe de um dos frequentadores da Inverso, chegou um pouco atrasada, mas mesmo assim, puxou uma cadeira e sentou na mesma do grupo que já continuava o debate. Ao ser apresentada ao contexto da pesquisa e ao tema que discutíamos no momento - sobre os motivos de ter se interessado pela tv - Maria disse que preferia não falar, justificando saber muito pouco sobre Tv Sã. "Você sabe igual" retrucou Fabiana. Diante da sua importante contribuição tanto no grupo, quanto na pesquisa, negociei com Maria um nome fictício ao final da entrevista, de modo a deixá-la mais confortável. Concordando com esses termos, ela assinou o TCLE. Talvez pelo fato de 
ser a primeira e única familiar a participar do projeto, pode-se dizer que sua posição na pesquisa traz características particulares.

Diante da pergunta disparadora, a participante em vez de relatar sua experiência, tal como fez os demais participantes, questionou sobre a viagem que alguns profissionais da Inverso fizeram juntos a Trieste, com o objetivo de conhecer os efeitos da reforma psiquiátrica naquela cidade. Mesmo se tratando de um passeio turístico, financiado pelos próprios voluntárioss durante o período de férias da instituição, Maria queria saber porque não houve nenhum momento de troca após o retorno, já que "aqueles que ficam no país esperam alguma novidade", como ela colocou.

As reuniões da Tv Sã acontecem no espaço da Inverso, mas ao mesmo tempo, parece ser uma atividade mais ou menos autônoma em relação às demais programações do local. A oficina de vídeos faz parte da lista de atividades que o centro oferece, ela se organiza a partir do calendário da instituição e respeita as mesmas regras de convivência acordadas com todos os frequentadores, tal como o uso da chave, horário de funcionamento, etc. No entanto, a história do núcleo de comunicação teve seu início fora da Inverso, estabelecendo com ela uma relação de parceria. Esse duplo lugar de pertencimento - de dentro e de fora - traz um outra faceta para o grupo da Tv Sã, conferindo-lhe um papel de intermediária das questões latentes que surgem sobre a ONG. Vale lembrar que nem todos participantes da oficina de vídeo são frequentadores da Inverso, alguns estão vinculados exclusivamente à Tv Sã.

Além de prestar informações à comunidade sobre as demais oficinas que acontecem no mesmo centro, a Tv Sã deve promover uma discussão que dissolva as hierarquias entre os saberes dos estudantes ou profissionais da psicologia e os saberes dos familiares. Após a realização do vídeo Tudo acontece em família, ficou ainda mais evidente a necessidade de encontros específicos para essas trocas, para desconstruir os lugares de poder do saber científico representado como o "tudo" e o saber popular como o "nada". "Pra vocês que estão estudando não tem muita novidade que apesar de você não ter ido lá você sabe tudo. Mas pra nós que não sabemos nada sobre saúde mental desse modelo de lá que veio pra cá. (...)". Ainda nessa fala, chama a atenção a ênfase dada ao modelo italiano como aquele que é "de lá", aquele que, sendo estrangeiro e desconhecido, provoca expectativas para novas mudanças "pra 
cá". Mas será que para encontrar melhores caminhos precisaremos sempre recorrer às experiências européias? Por que o curso "de lá pra cá" ainda nos parece mais proveitoso e sedutor que o seu inverso? Ainda que o intercâmbio cultural seja uma oportunidade de crescimento para descobrir novas estratégias de desinstitucionalização, é preciso reconhecer os riscos de adotar a referência estrangeira como norte. Não podemos desconsiderar a diversidade das mais ricas experiências antimanicomiais brasileiras e incorrer a um movimento colonizador.

Ainda analisando a posição de Maria, destaco outro trecho de sua fala que revela seu dedicado monitoramento sobre a frequência dos frequentadores da Inverso. "Eu fico vendo 'Elias, tem vindo? Elias não tem aparecido mais'. Não está vindo, eu digo assim, 'tem qualquer coisa acontecendo'. Eu pergunto "Rodrigo, Elias veio hoje? Elias veio hoje?". Eu fico monitorando (risos)." A vigilância sobre a assiduidade dos frequentadores e o sentimento de suspeita, de que algo está fora do previsto quando eles não vão, nos oferece indicadores para supor que o não comparecimento às oficinas é percebido como algo negativo. A não obrigatoriedade das atividades mune o sujeito de liberdade, ele escolhe se deseja ir ou não à instituição. Significa dizer que o frequentador que não está diariamente na ONG pode estar envolvido com outra atividade que ele considere mais interessante ou que não sinta mais necessidade de frequentar o espaço.

O desejo da instituição, conforme explicou Fabiana, participante da Tv Sã, é "que as pessoas não precisassem da Inverso, que elas se emancipem, que elas ocupem os lugares. Então aqui é um lugar de passagem, de transição, não um lugar pra ficar. A ideia é essa, as pessoas tem que entender. Não é que é ruim isso." É possível inferir que, ainda que a Inverso não exiga a participação obrigatória e não necessite controlar o tempo do frequentador na instituição, essa dinâmica aparece no discurso dos familiares. Acredito que esse estranhamento sobre a oscilação nas participações pode estar associado à incorporação do funcionamento regrado de outros serviços de saúde mental. Abrir mão de uma rotina rigorosamente ordenada pela instituição pode gerar algum incômodo aos familiares que precisarão encontrar o seu próprio modo de organizar o tempo.

Na Tv Sã, o modo de convivência possui características bastante acolhedoras. Existem alguns participantes se expressam espontaneamente, se posicionam diante das votações, mas apresentam um discurso extramamente desorganizado. Acrescento 
aqui que, embora o fenômeno da para-resposta tenha surgido durante as entrevistas focais, em nenhum momento ela foi desconsiderada pelos demais participantes. Esse tipo de linguagem indicativo de um sintoma esquizofrênico (Dalgalarrondo, 2009) é recebido pelo grupo como uma disposição criativa do modo-de-ser do indivíduo. Ainda que a fala caótica possa desestabilizar a linha de pensamento durante a discussão do grupo, o conteúdo dessa fala geralmente é incluído como forma de legitimar e incentivar a participação de todos. Evidentemente, é preciso considerar que os lapsos de sentido e o momento em que esses aparecem não surgem por acaso, mas está ligada a história de vida singular de cada sujeito.

Durante o relato de Fabiana sobre a importância de sair dos lugares fixos que a sociedade estabelece para nós, Rodrigo interrompe a fala dela para acrescentar seu comentário. Os outros participantes também acolhem seu pensamento e reconhecem nele sua legitimidade e importância para ampliar as questões do debate:

R: As vezes o pessoal acha que é uma coisa e é outra, uma pinga, por exemplo, a cerveja... A pinga e a cerveja é "destinado" da natureza, as coisas boas da vida vem da natureza. Vem do verde, vem da vida, ne? Um prazer que muitas vezes as pessoas criticam, muitas vezes não sabem.

F: É interessante você falar isso porque, assim, essa semana eu pensei nisso..

H: Ayahuasca também tem verde...tem um negócio de cura com isso aí.

F: É pois é (risos). Olha só, você vai ter que cortar um monte de coisa dessa entrevista, mas só pra puxar esse papo da pinga natural e da ayahuasca, por exemplo, eu estou com um recém-nascido da minha irmã e quando ele acorda, ele acorda berrando, mas não é chorando não. Solta uns gritinhos, se espreguiça. Isso aqui é teatro, é canto, é tanta coisa. O bebê, a criança, trabalha tanto o corpo e a voz e a gente vai ficando rígido, rígido, rígido e vai perdendo essa espontaneidade. Igual você falou o lance da cana, da raiz... Então a gente vai saindo desse contato com as coisas mais naturais mesmo, a gente sente falta disso. Aí eu acho que esses trabalhos com coisas criativas puxam uma naturalidade até do corpo, de sair um pouco dessas estruturas rígidas.

Não cabe aqui supor que a fala de Rodrigo esteja associada à proibição da sua mãe sobre o uso de cigarro. Nos interessa analisar a dinâmica do grupo em relação à sua fala aparentemente desconexa. Levando em consideração que alguns participantes mais comprometidos costumam se expressar menos, o grupo também dá a mesma atenção a essas falas, mesmo que elas apresentem alterações mais notáveis, como os neologismos patológicos, as estilizações, rebuscamentos e maneirismos. O fluxo verbal deorganizado não é um problema para as sessões de brainstorm, afinal, são nesses espaços que eles podem ser ouvidos, fazendo com que sua linguagem assuma suas funções de afirmação do eu, de comunicação e sua dimensão artística e lúdica tão 
pouco exploradas nas instituições. Ressalto ainda que valorizar a expressão desses participantes não significa ignorar os indicativos de desestruturação esquizofrênica, mas sim, escutá-los antes de buscar incessantemente as definições correspondentes aos manuais psiquiátricos.

Vários estudantes estagiários, na ansiedade de comprovar seu aprendizado, com frequência me procuravam após as reuniões da Tv Sã questionando "Qual é o diagnóstico dele? Ele é esquizofrênico?". No contexto do mestrado, ao acompanhar alguns alunos nas visitas dos serviços em saúde mental pude observar um resultado bastante positivo. Tive o prazer de encontrar alguns rostos conhecidos nas reuniões do MPSM-DF e tantos outros compondo a organização de eventos de luta antimanicomial em diversos espaços, articulando debates em universidades e comunidades. Entretanto, nem sempre o interesse dos estudantes por essa temática passa automaticamente por uma sensibilização. Certa vez, terminada mais uma reunião da Tv Sã, uma aluna entusiasmada com seu primeiro encontro tête-à-tête com usuários de saúde mental, compartilha comigo seu fascínio pela sua capacidade em reconhecer a listagem dos sintomas psiquiátricos em uma pessoa. Mesmo compreendendo a sedução que o saber circular desperta ao encontrar mecanismos para justificar a redução da vida ao diagnóstico, não hesitei em cobrá-la uma postura ética em relação ao outro - afinal, o sofrimento psíquico está muito além de um catálogo de sintomas psiquiátricos clássicos. O sentimento de poder ao afirmarmos algo sobre outro deve ser feito com bastante cautela para não agirmos de forma alienadora.

O modo de funcionamento da Tv Sã claramente coloca a doença entre parênteses e valoriza o sujeito como autor de sua própria história. Ainda que as frases de auto-definição, como "sou bipolar" ou "sou esquizofrênico", não tenham completamente desaparecido, percebo que os discursos tiveram alguma mudança qualitativa, atribuindo maior ênfase às atividades que eles desenvolvem. "Doente" e "paciente", "usuário" por exemplo, são palavras quase nunca utilizadas, em seu lugar vemos "pessoa com problemas em saúde mental". A meta é que mais participantes saibam recusar o rótulo dos diagnósticos e qualquer outro rótulo que não reconheçam como seu.

P: E você, Elias. Membro fundador né?

E: Não. 
F: Isso deixa ele constrangido, eu acho que isso que deixa ele preocupado com a fala dele.

E: Essa história de membro fundador não cola, não cola!

P: Você está desde o início da tv sã...

F: Oxi, na minha entrevista você disse "Eu sou o presidente, eu sou o grande rei". Brincadeira! (risos)

E: (risos) Deixe de conversa!

Nesse trecho, vemos que o título de "membro fundador" atribuído a Elias, mesmo sendo o membro mais antigo do grupo, para ele "não cola". Ainda que sua participação como diretor no vídeo Me escuta, Brasília tenha rendido repetidas parabenizações pela equipe, ele prefere estabelecer uma relação de igualdade em relação aos demais participantes. Elias, participante assíduo das reuniões, percebe hoje, a partir de um olhar retrospectivo as transformações de sua própria história. Diante de tantos desafios enfrentados em relação a família, os serviços e a sociedade, as oficinas de vídeo sem dúvida o ajudaram, mas o mérito é todo dele. A voz que quase não se ouvia nas reuniões foi se tornando mais forte e frequente, e hoje também é voz no setor de Comunicação do Movimento Pró-Saúde Mental. É voz, é corpo, é sujeito e cidadão.

Atualmente é possível observar o usuário de saúde mental tornando-se um ator social expressivo no campo político. Talvez, os profissionais desses serviços ainda não acompanharam essa tendência na mesma proporção. Conforme aponta Oliveira e Alessi (2005), os trabalhadores da área ainda atuam como agentes da repressão refletindo muito pouco sobre sua função social. "A percepção de si mesmo como cidadão é, portanto, esvaziada ou ausente, nesses profissionais, como de resto é também em grande parte da sociedade atualmente." (p. 198). Se a consciência de cidadania parece não ter sido aflorada para a maioria da população, consequentemente o protagonismo dos usuários dos serviços não é legitimado como deveria. Esse engajamento político parece ser um movimento tão inusitado para alguns que, parece mais lógico crer que, aqueles que militam e conhecem a legislação, só podem ser servidores, e não usuários do serviço.

Elias conta na entrevista grupal que vê graça quando algumas pessoas pensam que ele é um profissional militante na área. Por acompanhar a maioria dos debates em saúde mental e estar envolvido nas mesmas reuniões que estão presentes trabalhadores reconhecidos no campo, às vezes ele é confundido com os demais profissionais, mas esclarece a diferença: 
E: Aí eu tive que explicar para ela que eu não fico envolvido o tempo nas reuniões que a Juliana Pacheco se encontra porque nem tudo que ela faz é o que eu faço. Porque ela faz na maioria das vezes como profissional, e eu não. Eu faço exatamente para poder lutar pela causa. É o que muitas vezes eles não conseguem entender, eles pensam que eu tenho um profissionalismo ao ponto de saber as coisas, de me envolver como um profissional da mesma área.

F: Mas eu acho que isso também é válido. Como você realmente já adquiriu bastante conhecimento, você saiu da posição de que é colocado como aquele que precisa de ajuda para uma pessoa que está ajudando e está transmitindo conhecimento. E aí quando uma pessoa te reconhece como um profissional, é ótimo. Não tem problema não.

H: Aí você tem nome, você tem voz para colocar...

O que esses rótulos nos revelam? Usuários de saúde mental não são engajados em debates políticos, não conhecem seus direitos e, portanto, não tem voz para colocar. Do outro lado, estão os profissionais, os verdadeiros protagonistas que dominam a lei, tem conhecimento e sabem transmiti-lo. O profissional que não surta, o usuário que não pensa. O profissional que tudo sabe sobre a lei e a loucura, o louco que nada sabe sobre e si e sobre o mundo. Por que a coexistência desses papéis numa mesma pessoa parece ser tão contraditória?

A figura do usuário de saúde mental que conhece seus direitos e luta para garantí-los é irreconhecível em seus próprios contornos, ela transgride o convencional. Mais que isso, essa personagem revela a impermanência da linha imaginária entre o mundo da razão e da desrazão e levanta questões sobre a construção de uma sociedade democrática. Ora, na verdade essa linha que divide esses dois mundos é como traçado na areia. Para aqueles que vêem de longe o debate, a demarcação ordena claramente o que há de um lado e o que há do outro, não havendo dúvida sobre a qual espaço cada um pertence. Mas quem se aproxima com cuidado dessa linha, observa que o próprio traçado, fragilmente montado na superfície da areia, está composto por infinitos grãos, por uma existência concreta de milhares de "trizes" que apontam a penetrabilidade dessa divisão até então intransponível. À distância de um triz de um lado, à distância de um triz do outro. Ao movimento de um sopro tudo se desfaz.

Mesmo que muitos profissionais não se reconheçam como agentes de transformação - e reconhecem menos ainda os usuários de saúde mental - essa "militância do oprimido" vem com força para abalar essas convições incapacitantes. A naturalização dessas posições hierarquizadas é sim uma situação problemática. Que tipo de democracia queremos quando só os profissionais tem voz? Que tipo de 
protagonismo estamos incentivando quando apenas o usuário letrado pode falar? Os usuários devem ser reconhecidos pela sua capacidade de atuar no campo político, independentemente de sua escolaridade. Valorizar a democracia é permitir que todos possam falar.

Ainda que existam profissionais comprometidos com a luta antimanicomial, inevitavelmente eles também são atravessados por interesses particulares da categoria, como por exemplo, a redução de jornada de trabalho sem a redução salarial. Existe uma diferença na participação do profissional-militante e do usuário-militante, essa demarcação é expressa em "ela faz na maioria das vezes como profissional, e eu não. $\mathrm{Eu}$ faço exatamente para poder lutar pela causa". Uma causa que não vem travestida de saber psicológico, mas se apresenta para todos em uma sincera nudez, que não se contabiliza em horas de uma jornada, mas se faz na jornada de uma vida.

Ao longo da entrevista grupal, ficou evidente que essa luta está além do desejo de reformar o sistema da saúde mental, ela engloba questões sociais mais amplas, envolve um desejo de mudança. Trazer para discussão temas atuais, como a proposta de redução da maioridade penal, indica que o grupo está a par dos debates políticos, se posicionando no mundo de forma crítica e exercendo sua cidadania. Longe de ser uma conversa rasa e desprendida, a lucidez na argumentação dos participantes trouxe uma análise bastante complexa sobre a nossa realidade, sempre apoiada em elementos factuais da comunidade.

E: A mídia joga pra você como se você fosse obrigado a aceitar tudo o que ela está mostrando. O principal problema que ela está mostrando atualmente é exatamente com relação ao adolescente. (...) Esses jornais da Record e do canal 6 só falam que o jovem é problema, mas quando a gente vai ver no correto, eles se esquecem que a educação não existe, o professor é esquecido, a melhoria para a família poder ter base e vida não existe, os direitos humanos não aparecem para ajudar a pessoa a vencer esse problema. A principal vontade deles é que essa pessoa vá parar na cadeia, porque lá é o melhor lugar para ela ser reeducada. Como é que eu vou reeducar uma pessoa se eu não dou para ela uma chance de vida? (...) Porque se ele tivesse a educação desde o princípio, com certeza, no futuro dele, não se tornaria exatamente a pessoa que comete atos infracionais. A educação é uma base para a sociedade.

O debate sobre a redução da maioridade penal se propagou pelas redondezas. Elias relatou que sua vizinha, telespectadora desses canais citados, sempre mostrava uma diferente da sua, apresentando panfletos e documentos na internet com conteúdos a favor da redução. Contrário a esse pensamento, Elias exemplifica seu 
posicionamento contando a história de seu sobrinho que, sem o apoio da família e do Estado, "acabou se bandeando pro lado errado". Assim, ele conclui que a falta de incentivo à educação também foi um fator determinante no seu caminho.

O desenrolar dessa discussão, mesmo não tocando explicitamente o tema da saúde mental, trouxe um raciocínio pertinente para esse estudo. Criticar o modo como as mídias representam o adolescente em conflito com a lei é reconhecer que a perspectiva individualizante, desvinculada do sistema que o constitui, jamais resolverá o cerne da questão. A cadeia como solução ignora toda a cadeia de fatores implicados nessa problemática. Ao substituirmos a figura do adolescente pela do louco, percebemos que o ponto é o mesmo: se educar não é prender; então cuidar não é trancar.

Deixar o grupo conduzir o assunto de modo espontâneo, abordando inicialmente a questão da redução da maioridade penal, foi uma estratégia de pesquisa que produziu um resultado bastante positivo. Por conseguinte, o raciocínio desenvolvido durante a discussão sobre essas questões subjacentes à saúde mental provocaram uma reflexão muito mais aprofundada sobre a nossa realidade que certamente forneceu componentes ricos para a construção do discurso coletivo. Além disso, por se tratar de um grupo cujos participantes pertencem a classes sociais distintas, esse método permitiu que o tema fosse explorado sem desconforto, tanto para aqueles que frequentavam hospitais psiquiátricos públicos, quanto para aqueles vinculados às clínicas particulares.

O dinamismo e a boa interação do grupo trouxeram um outro ponto interessante. Seria a educação a grande salvadora do nosso futuro? A verdade é que o mito da escolaridade como a principal garantidora de empregos não tem mais valor, os jovens mais pobres não se iludem mais, afinal, "ter estudo não garante que se vá trabalhar, e ter trabalho não garante que continuará trabalhando." (Novaes, 2006, p. 107). O imperativo "viver para trabalhar" que repria a ferro e a fogo os ociosos a ferro é hoje introjetado pelos indíviduos com a mesma violência. Agora recaí para o próprio indíviduo a responsabilidade - antes atribuída ao Estado - de contornar os efeitos das desigualdades sociais. "Todo o remédio que eu tenho que comprar não tem no hospital público. Tem mês que eu gasto 600 a 800 reais com os remédios, às vezes eu recebo bem menos do que isso pelo INSS, eu vou ter que trabalhar."

L: A educação, lógico, é fundamental, mas ela se atrela junto com a cultura. Se tiver, por exemplo, oficina de artes junto com as escolas, oficinas de vídeo, 
de informática, de música, essas coisas, desenvolvem talentos nas crianças, nos adolescentes. Eles vão querer se profissionalizar em outras áreas, nas áreas artísticas e nas tradicionais também - administração, medicina, outras áreas. Acaba abrindo um leque maior pras pessoas se profissionalizarem.

De modo complementar, Léo aponta a influência da cultura na continuidade de uma futura carreira profissional desses jovens. O estímulo à produção artística e critativa pode ser um espaço de descobertas de talentos, de valorização desses jovens e inserção no mercado de trabalho. Vale lembrar que a escola também é uma instituição normativa que funcionar como instrumento de controle social e alienação ou como instrumento de libertação, de emancipação. Tendo em vista o predomínio de uma concepção bancária de educação, torna-se fundamental resgatar a dimensão cultural para por fim a ideologia da opressão. A cultura traz ao processo uma força transformadora, ela reconecta os indivíduos à realidade, modifica as palavras alienantes e alienadas em pensamentos originais repletos de significados. A cultura rompe os esquemas verticais, questiona os "argumentos de autoridade" e abre caminhos para uma educação libertadora. (Freire, 1997). Frente a um cultura educacional que busca transformar a mentalidade dos oprimidos, e não a situação que os oprime, torna-se um desafio ainda maior lutar pela emancipação num contexto marcado pela dominação:

H: Porque assim, o que mais você vê é muita gente instruída cometendo crimes. A politicagem é muito criminosa. Só a falta, essa abstinência de recursos pra saúde mental é um grande crime que vem de pessoas muito instruídas, que tiveram educação, tiveram recurso, cultura, tudo que é necessário pra construção de um ser humano. Ou seja, educação de um lado, dos que tem o poder, não serve de nada pra quem está lá embaixo, quem não teve educação, sabe? Não tem essa interação, não tem essa ligação, não favorece em nada nesse negócio de saúde mental.

$\mathrm{O}$ acesso à educação não será o único determinante na formação pessoal e profissional do indivíduo. Ainda que pudessemos oferecer iguais condições de ensino a todos os indivíduos, transformando a escola em um verdadeiro espaço de desenvolvimento autônomo, de estimulação da criatividade e do pensamento crítico, não poderíamos supor que cada um fosse "ajustado" à mesma medida. Aprender envolve toda uma produção subjetiva cuja qualidade não está definida apenas pelas operações lógicas que estão na base desse processo. Felizmente, a intenção de converter a escola numa fábrica de indivíduos normais não é realizável diante da potência da singularidade dos sujeitos. A vida escapa às instituições. 
Não desprezando a importância do processo educativo para a construção de um projeto coletivo de uma sociedade mais justa, podemos resumir a fala de Henrique da seguinte forma: intruído ou não, rico ou pobre, todos podem agir corruptamente inclusive utilizando o próprio ensino como forma de alienação e reprodução de práticas excludentes. Essa constatação de que todo ser humano é virtualmente equivalente, levantou um questionamento crucial para o debate: por que existem encaminhamentos diferentes para condições sociais/econômicas diferentes?

A loucura é para todos, mas como já dizia Basaglia (2001), louco pobre e louco rico não são recebidos pela psiquiatria do mesmo modo. Essas disparidades nos levam a perceber que a luta pela reforma psiquiátrica é movimento social mais amplo de combate às formas de opressão e de exclusão

Portanto, é um processo de desinstitucionalização do social, do nosso apego às formas de vida institucionalizadas, onde é preciso produzir um olhar que abandona o modo de ver próprio da razão, abrir uma via de acesso à escuta qualificada da desrazão, e considerar outras rotas possíveis que possam não apenas lutar contra a sujeição fundante da sociabilidade capitalista, mas também instigar a desconstrução cotidiana e interminável das relações de dominação. (Alverga \& Dimenstein, 2006, p. 303)

Para desconstruir essas relações de dominação é preciso ouvir os gritos mudos de desesperança no cotidiano dos serviços. A exibição do vídeo da Tv Sã Tudo acontece em Família no CAPS - Taguatinga presumia despertar um fervoroso debate sobre as dificuldades enfrentadas nas relações com os familiares e com a instituição. O grupo percebeu que, embora muitos relatassem sobre seus conflitos em casa, ninguém mencionou diretamente os conflitos no serviço de saúde mental. Alguns declaravam uma enorme gratidão, abençoando a vida dos servidores que prestavam assistência. Não houve nenhum descontentamento explícito sobre alguma medida tomada pelo CAPS.

Há um clima aparentemente de "harmonia" entre os trabalhadores e entre esses e os usuários. A submissão do mais fraco ao poder do mais forte é tacitamente realizada, em função da percepção da realidade, por parte dos usuários, de que não pode haver qualquer outro encaminhamento para essas situações (...) tentar uma aliança com o mais forte é o recurso comumente encontrado pelos oprimidos; a aliança com o usuário - tão prejudicado e oprimido quanto os servidores de nível médio que permanecem no serviço mesmo na ausência do médico - é descartada em favor de uma observação tácita e implícita de que o mais forte/opressor é inacessível e inatingível e, em sendo assim, resta se aliar a ele na opressão do outro. (Oliveira \& Alessi, 2005, p. 200) 
Logo após a reunião no CAPS, o grupo compartilhou as impressões sobre esse silêncio. O tema voltou a aparecer na entrevista grupal e os participantes elaboraram hipóteses sobre a razão desse fenômeno. Desvendar o segredo da "convivência harmoniosa" nos serviços é romper com a naturalização da violência que sustenta o sistema da manicomialidade. Expor essas cartas é fundamental para acabar com o jogo da dominação.

E: O problema é eles saberem que aquilo ali precisa ser exposto pra trazer conhecimento e mostrar para o profissional que ele não é o dono daquele local onde ele presta serviço.

M: Tem reclamar numa ouvidoria onde as pessoas não fazem parte porque ali sempre tem as pessoas que fazem parte. Porque se falar certas coisas a pessoa pode perder o cargo.

E: Mas ele não perde o cargo, muitas vezes ele sai daquela função ali e vai pra um outro local fazer o trabalho. Isso acontece com muitos profissionais, eles saem daquela função, daquela área ali e vai pra outra. Eles (usuários) não tem coragem de falar exatamente por isso, porque parece que tem medo de perder aquele atendimento.

L: Ninguém nunca denunciou um tipo de serviço totalmente precário que é lá (HSVP). Lá não é limpo, a maior parte do tempo é sujo, comida no chão...e é um hospital. Ninguém nunca denunciou, sempre estão acreditando que lá é um paraíso. Por que não denuncia? - essa é a minha dúvida.

M: As pessoas que passaram por lá pra denunciarem, é muito arriscado.

L: É, pra denunciar eu preciso ter fotos, vídeos, essas coisas.

Logo na primeira fala, vimos a necessidade do técnico desapropriar-se da sua posição de poder para permitir que as falhas sejam apontadas e reparadas. Quem quer ser o primeiro delator de situações que poderiam inclusive justificar uma demissão? Que implicações essa denúncia traz para o denunciador? O técnico não perde efetivamente seu cargo, ele é remanejado, o usuário, por outro lado, pode ficar desassistido. Se no CAPS a inconformação é velada, no HSVP o quadro é ainda mais precário. Trazer a tona as torturas e os abusos que acontecem ali "é muito arriscado". Acredito que estamos mesmo diante de um risco real em que o usuário pode ser, por diferentes formas, definitivamente calado.

Se nas décadas de 1960 e 1970 as denúncias de abandono, de violência e de maus-tratos nas instituições psiquiátricas fomentaram o início da reforma psiquiátrica no Brasil, significa que devemos continuar a fazê-las. É a força da denúncia, do relato da experiência vivida, que põe em risco a estrutura psiquiátrica manicomial. Vídeos, fotos e fatos para embasar essas queixas são recursos que podem ampliar a visibilidade dessas questões para a população. As paredes do HSVP ocultam muitas 
histórias de violências que permanecem sob o sigilo da instituição. É tempo de revelálas e interromper ciclo.

Pensando nisso, a Tv Sã tem se reunido para elaborar um novo roteiro cujo personagem principal será o próprio HSVP. O antigo HPAP - Hospital Pronto Atendimento Psiquiátrico, como é popularmente conhecido ainda hoje, tem uma história peculiar. Nessas mesmas instalações, muito antes das tentativas frustradas em fazer funcionar Hospital-Dia, já funcionou uma maternidade. Muitas pessoas, inclusive usuários de saúde mental, se supreenderam ao descobrir que nasceram ali. Eles foram acolhidos no mundo através da medicina, da passagem do escuro protegido do útero à condição mais dependente e frágil do primeiro momento da vida. A mesma ciência que, à luz da psiquiatria, retirou-os do convivívo para enclausurá-los no vazio solitário do hospital, marcando o início do processo de mortificação. Explorar o claro e o escuro, o nascimento e a morte são elementos interessantes para representar os paradoxos dessa trajetória da instituição. Na história do HSVP, muitas verídicas serão contadas através da interpretação de atores/estudantes que dramatizarão os depoimentos de ex-internos. Sem dúvida é um grande projeto que trará contribuições valiosas para o processo de desinstitucionalização.

\section{6 - O Discurso Coletivo da Tv Sã}

Nem um grupo terapêutico, nem uma reunião de usuários de saúde mental, o grupo Tv Sã é um coletivo, "um dispositivo participativo propício e potente ao exercício de protagonismo". (Costa \& Paulon, 2012) Nesse modo de funcionamento, o grupo estabelece uma vinculação afetiva entre seus membros, ou seja, o trabalho coletivo não refere-se a uma linha de montagem, mas a uma experiência de troca e de criação. Desse modo, a construção de vídeos deve passar pela produção de sentidos incorporados à identidade de cada participante. Significa dizer que o objetivo da existência da Tv Sã está além do desejo comum em potencializar as modificações propostas pela Reforma Psiquiátrica, mas também diz respeito ao desejo singular de cada sujeito.

Nesse sentido, para analisar o objetivo desse coletivo a partir do discurso de cada participante, as falas serão organizadas em categorias construídas a posteriori. Esse método de categorização, estabelecido a partir das expressões chave e as idéias centrais, é facilitado pelo software Qualiquantisoft que sistematiza todas as informações, compondo, num segundo momento, o DSC. Segue, como exemplo a 
tabela 1, referente à primeira pergunta disparadora. As demais tabulações estão localizadas nos anexos desse trabalho.

\section{Tabela 1 - Discurso do Sujeito Coletivo 1}

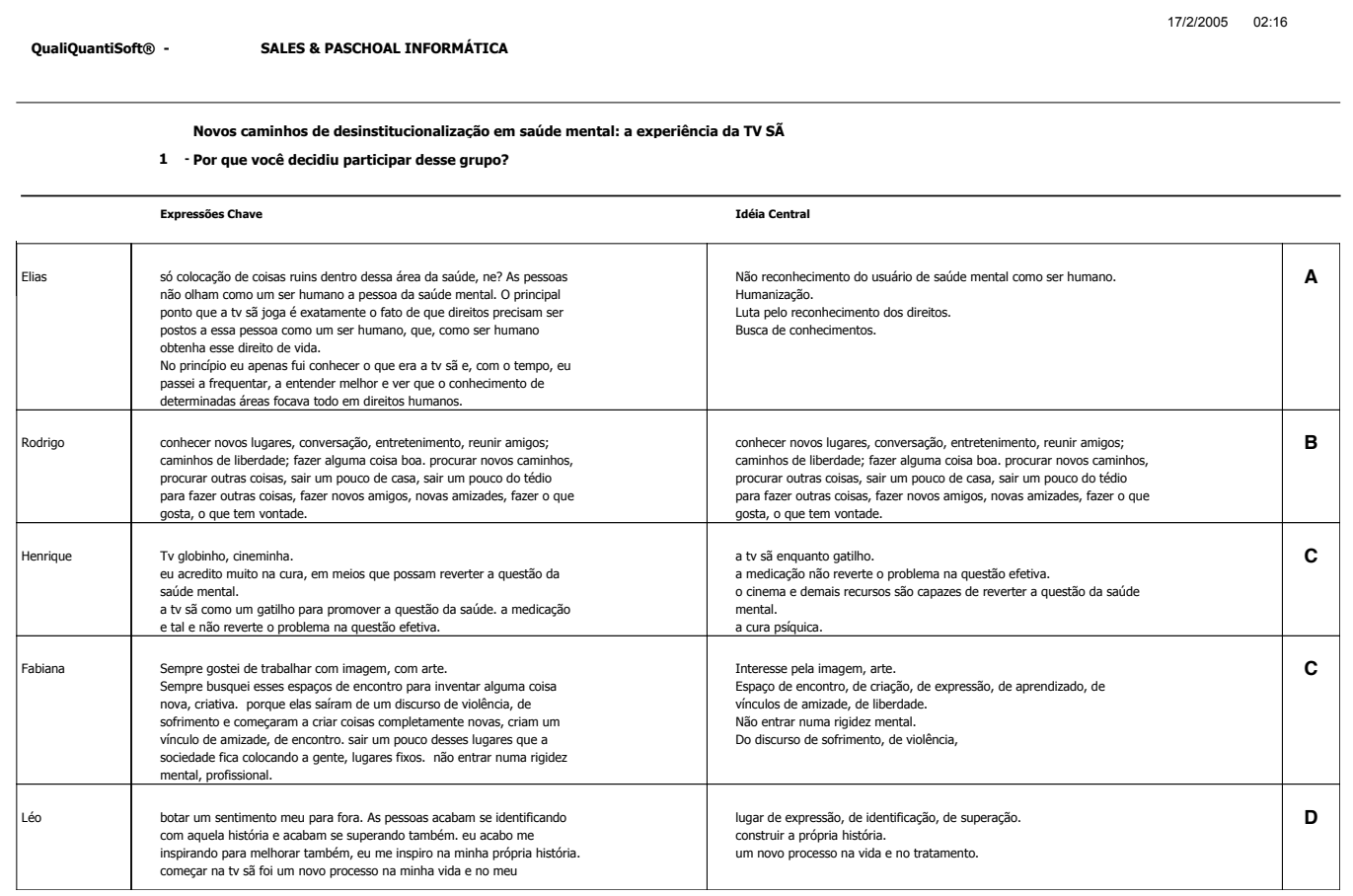

A pergunta "Por que você decidiu participar desse grupo?" produziu três categorias de resposta: a) Reconhecimento dos direitos de cidadão; b) Vínculos e trocas; c) Expressão, cultura e criação; d) Processo de identificação e crescimento. Para a leitura da tabela, é importate lembrar: nem todos os participantes respondem à questão colocada para o debate e diferentes respostas podem ser agrupadas numa mesma categoria, não implicando em prejuízos para a construção do DSC. É possível constatar que a investigação sobre motivações de cada participante em entrar na Tv Sã resgata a dimensão subjetiva e afetiva, delineando os objetivos do coletivo de modo mais profundo, sem recorrer a discurso artificializado de um coletivo homogêneo. A partir da categoria A, produziu-se o seguinte discurso:

DSC1A: As pessoas não olham como um ser humano a pessoa da saúde mental. O principal ponto da tv sã é mostrar exatamente a importância de que os direitos precisam ser postos a essa pessoa, como qualquer ser humano que tem direito de vida. No princípio eu apenas fui conhecer o que era a tv sã e, com o tempo, eu passei a frequentar, a entender melhor e ver que o conhecimento de determinadas áreas focava todo em direitos humanos. 
O leque de oficinas na rede de atenção psicossocial no DF normalmente é bastante reduzindo, integrando sempre as mesmas atividades de baixo custo, como artesanato, desenho, colagem, etc. Conhecer uma tv comunitária em saúde mental provavelmente é uma proposta que desperta a curiosidade. Alguns perguntam "qual é o canal? Vou ficar famoso?". Claramente a Tv Sã não tem estrutura para transformar um anônimo em celebridade, mas tem potencial para problematizar o campo de visibilidade do publicamente reconhecido. Ou ainda, de transformar as normas de reconhecibilidade para finalmente reconhecer a humanidade daqueles que sofrem.

Nesse sentido, a participação no grupo abriu as portas para um novo campo de conhecimento até então inacessível, os direitos humanos. A figura desumanizada do louco é desfeita e se constrói em seu lugar o sujeito da diferença enquanto sujeito de direitos. O funil da cidadania que deixava passar apenas o sujeito requerido pelo projeto da modernidade, agora se alarga.

Os direitos, assim como o sujeito de direitos, não nascem desde fora da relação; nascem do âmago do ser com os outros. Nascem do chão duro das interações conflituosas que marcam a convivência. Mais do que para regular, servem para gerar possibilidades emancipatórias. (Carbonari, 2007, p. 177)

Conforme aponta Carbonari (2007) tal emancipação refere-se ao ser livre e autônomo. Uma liberdade que nada tem a ver com uma noção privatista "minha liberdade vai até onde inicia a do outro", mas que relaciona-se com a construção de uma subjetividade aberta e relacional. A dimensão dos vínculos afetivos e das trocas de experiência constitui a categoria "b":

DSC1B Tem a ver com conversação, entretenimento, fazer alguma coisa boa, procurar novos caminhos. Conhecer novos lugares, reunir amigos, sair um pouco de casa, sair um pouco do tédio para fazer outras coisas, fazer novos amigos, fazer o que gosta, o que tem vontade. São caminhos de liberdade.

O manicômio é o lugar zero da sociabilidade. A internação e a tutela tem como objetivo diminuir as trocas e aumentar as relações de dependência pessoal. (Rotelli, 1990). "Os caminhos de liberdade" seguem em direção oposta aos descaminhos da institucionalização. Transitar por outros espaços e construir novos vínculos apontam para uma desconstrução do manicômio que extrapola o contexto institucional específico. O sujeito rompe com a lógica do isolamento e faz o caminho inverso ao da "carreira moral" dada pela instituição. O sentimento de inferioridade instaurado pelas 
crenças deformadas a respeito de si e dos outos, na convívência, poderão ser gradualmente desfeitas. O corpo institucionalizado, enrijeicido e mortificado, se reestabelece pelo retorno ao toque e à afetividade. Agora, o corpo pessoal explora sua vontade própria, podendo inaugurar novos lugares para além da barreira que as instituições colocam entre o mundo interno e o mundo externo. (Goffman, 1979)

A categoria "c" que envolve expressão, cultura e criação, está intimamente relacionada com os vínculos sociais/afetivos estabelecidos no gupo e o processo criativo na produção áudio-visual.

DSC1C: Eu acredito em meios que possam reverter a questão da saúde mental já que só a medicação não é efetiva. Sempre busquei esses espaços de encontro para inventar alguma coisa nova, criativa, para não entrar numa rigidez mental, profissional, pessoal. Trabalhar com imagem, com arte, sair um pouco desses lugares que a sociedade fica colocando a gente, desses lugares fixos. A Tv Sã pode ser um gatilho para promover a questão da saúde mental.

No lugar do sujeito da razão entra o sujeito da criação. Este, é um sujeito livre, multifacetado, em constante fluxo. Aquele é sujeito colonizado, moderno e fixo. A arte é um campo fértil para desenvolver o sujeito da criação, para questionar as proposições modernas que limitam o potencial humano. Em relação à saúde mental, reconhecer as limitações da ciência, desmontando-a desse lugar absoluto, representa uma abertura aos "caminhos de liberdade". Apenas a medicação não poderá trazer transformações efetivas para questões tão complexas. Como aponta Peixoto (2014) à luz de Merleau-Ponty: "o corpo não é uma coisa, não é uma máquina, nem é pura ideia, mas movimento, sensibilidade e expressão criadora." (p. 315).

O corpo é lugar privilegiado para a expressão de sentidos. Pela a arte e pela imagem é possível apresentar à sociedade este corpo-próprio, livre de estigmas. O movimento produzido pelo sujeito da criação é capaz de reverberar em outros corpos. Pode-se dizer que esse é um dos objetivo da Tv Sã: ser a faísca questionadora sobre as manicomialidades. A expressão criadora funciona como um disparador que produz mudança no corpo social, como "um gatilho para promover a questão da saúde mental". 
O curso que conduz o sujeito de criatura à criador, também envolve um processo de identificação e crescimento, que nos remete à categoria "d":

DSC1D: Começar na tv sã foi um novo processo na minha vida e no meu tratamento. Colocar um sentimento meu para fora, as pessoas acabam se identificando com aquela história e acabam se superando também. Eu acabo me inspirando para melhorar também. Eu me inspiro na minha própria história.

A narrativa de si mobiliza constantemente o reavivamento de lembranças. Essas recebem uma nova reissignificação a partir da emocionalidade. Vale lembrar que a escrita autobiográfica se estabelece não só a partir da inserção individual da memória, mas fundamentalmente na relação com o social e com a história de vida de quem narra. É por meio da produção de sentidos arranjados linguisticamente que as identidades são representadas e reconhecidas no complexo sistema simbólico social. Ou seja, quando as memórias das experiências vividas são ordenadas numa temporalidade criamos narrativas constituintes de uma ou várias identidades. É pela narrativa autobiográfica que o sujeito abre suas possibilidades de reinvenção durante o percurso de reconhecimento de si pela retomada reflexiva de suas ações e criações.

Esse tipo de relato o autobiográfico nunca aparece de forma isolada, nem pressupõe uma relação de linearidade entre o social e o individual, ao contrário, tratase de inter-relações entre o eu e o outro, caracterizando tal processo pela constituição mútua entre as dimensões. Assim, a linguagem é um dos pontos centrais capaz de expressar as múltiplas condições do sujeito enquanto ser social, discursivo e psicológico em sua forma de se apresentar ao mundo e de representá-lo.

Assim, compartilhar a própria história de vida é abrir-se ao um campo de virtualidades $^{25}$. Segundo Lévy (1996), esse conceito existe de forma latente ao atual, acompanhando as situações não enquanto ato, mas enquanto potência. Ou seja, a virtualidade $^{26}$ constitui uma dimensão importante da realidade já que é a partir dela que as potencialidades da atualidade são indicadas. Esse conceito traz ainda uma perspectiva dialética que deve ser considerada ao resgatarmos o debate sobre o público-privado e suas prováveis transformações nas relações intersubjetivas e facilidades para tornar público o que antes permanecia interiorizado.

\footnotetext{
${ }^{25}$ A origem da palavra virtualidade vem de virtualis, do latim medieval, derivado de virtus, significa força, potência.
} 
A passagem do privado ao público e a transformação recíproca do interior em exterior são atributos da virtualização que também podem ser muito bem analisadas a partir do operador semiótico. Uma emoção posta em palavras ou em desenhos pode ser mais facilmente compartilhada. O que era interno e privado torna-se público. Mas isto é igualmente verdade no outro sentido: quando escutamos música, olhamos um quadro ou lemos um poema, internalizamos ou privatizamos um item público. (Lévy, 1996, p. 73)

É interessante para essa pesquisa pensar o virtual não a partir de uma perspectiva comum, como aquilo que se opõe ao real, mas sim ao atual, como propõe Lévy (1996). Virtualidade e atualidade são maneiras diferentes de ser. Para explicar essa diferença o autor utiliza uma metáfora simples: a árvore encontra-se virtualmente na semente. Possivelmente essa semente se tornará árvore se consideramos que nada mude em sua determinação. No entanto, não podemos chamar o possível de virtual, pois esse já está todo constituído, como um real fantasmático, ou seja, como uma solução fechada. "O possível é exatamente como o real: só lhe falta a existência (...). O real assemelha-se ao possível; em troca, o atual nada se assemelha ao virtual: responde-lhe" (LÉVY, 1996, p. 16-17). O virtual, então, pode ser entendido como o "complexo problemático" ou o "nó de tendências" que acompanha uma determinada situação ou uma entidade e faz apelo a uma resolução: a atualização ${ }^{27}$. Sendo assim, a semente corresponde a esse problema já que a árvore se transformará e se inventará a partir de suas circunstâncias. Novamente, essa construção se dá a partir de uma perspectiva dialética, pois se "por um lado a entidade carrega e produz suas virtualidades (...), por outro lado, o virtual constitui a entidade (...)” (LÉVY, 1996, p.16).

Isso nos dá ferramentas para compreender as novas configurações de tempoespaço que se organizam nessas narrativas construídas em que a identidade pode constantemente se reconfigurar a partir de suas possibilidades de criação. É através de um complexo procedimento de um ato de criação que o sujeito pode alcançar essa nova configuração. A emoção intensa, tão somente, não é capaz de criar. É necessário antes de qualquer técnica que sirva como ferramenta para superar ou solucionar o sentimento que ali se expressa.

\footnotetext{
${ }^{27}$ Para Lévy (1996), a atualização pode ser definida como o movimento inverso da virtualização. No entanto, vale ressaltar que a virtualização "não é uma desrealização, mas uma mutação de identidade" (p. 17).
} 
Tornar público esses sentimentos por meio de palavras e imagens suscita uma serie de emoções, entre as quais a estética é apenas decorativa. Conforme aponta Vygotski (1970/2007), o papel da arte reduz não se reduz ao entretenimento e à diversão, mas envolve a capacidade de contagiar pessoas com os sentimentos. Um sentimento individual se transforma em social, mas um sentimento social que se converte em individual a medida que cada um vive ou sente a história que se conta. Significa dizer que a arte não apenas propaga sentimentos, mas também os transforma, ampliando suas possibilidades. "El arte representa más bien una organización de nuestra conducta para el futuro, una disposición hacia delante, una exigencia que, quizá, no llegue a realizarse jamás, pero que nos impulsa a aspirar por encima de nuestra vida (...)" (Vygotski, 1970/2007, p. 353)

Vale lembrar que a arte não se configura como uma atividade mística que envolve algum dom (Vygotski, 1970/2007), mas acredito que ela seja capaz de despertar todas as virtualidades da nossa realidade. Não é o mérito da questão discutir se é arte ou não a produção de vídeos da Tv Sã, se tem valor estético ou não. O interesse desse coletivo é promover uma potência criadora de espaços de liberdade. Diante da ditadura do belo ainda tão presente nas oficinas terapêuticas, fica a questão levantada por Alverga e Dimenstein (2006):

como pode a vida se expressar em toda a sua potência sob o crivo da clausura do belo? como poderia a arte escapar dos condicionantes impostos pela aspiração de se tornar mercadoria a ser consumida pelo olhar estrangeiro a procura do exotismo? (p. 313)

Como dizia o pintor Pablo Picasso "O belo não me interessa". Os juízos estéticos não podem falar mais alto que o potencial de criação e subversão da arte. (Alverga \& Dimenstein, 2006). A razão não pode dar limites à criação. Há muito ainda o que se explorar para que a arte seja percebida como uma técnica organizadora de sentimentos e narrativas que buscam saídas para tensões dolorosas e, por esse motivo, reconhecida como um campo fértil de estudo para a psicologia mergulhar nos sentimentos sociais mais profundos que trazem consigo revelações de novas possibilidades identificatórias e de potenciais educativos que visem desafiar a posição privilegiada das identidades hegemônicas ao denunciar as situações de opressão em nossa sociedade.

"Por que esse debate para o público por meio de vídeos?", é a pergunta que 
norteia o segundo momento do DSC dessa pesquisa. As categorias das respostas estão intimamente ligadas à discussão apresentada acima. São elas: a) Incluir toda a sociedade no debate da saúde mental, b) Troca de conhecimentos entre o grupo, c) Promover a diversidade na mídia. Complementando o que foi expresso no DSC1D, é possível inferir que a construção de vídeos age simultanemente na identidade narrativa e pessoal, assim como nas identidades coletivas. A Tv Sã funciona como um espaço de troca que, aliado ao trabalho de criação, produz sentidos que são incorporados à identidade de cada participante, ampliando sua autonomia.

DSC2B: É bom que você aprende a ver pontos de vistas dos outros. Aprende outros problemas, outros transtornos e outras formas de lidar. Por exemplo, tem situações que eu encontrei um aperto assim, e aí você vê pessoas que tem aquele transtorno e passam por aquilo facilmente, tem uma outra forma de lidar com o mesmo problema que você tem. E fora que você aprende que há saídas, como buscar os recursos mais fundamentais para amenizar aquela situação, aquele problema.

A formação do grupo desperta um sentimento de identificação e pertencimento. Compartilhar experiências comuns, trocar informações sobre como cada um passou pela crise, sobre a medicação, é também um exercício reflexivo sobre as capacidades de cada integrante. Encontrar saídas ou outras formas de lidar, é um recurso precioso que é descoberto no próprio convívio. Evidentemente esse ganho não deve se restringir apenas entre o próprio grupo ou ao campo da saúde mental. É necessário que a transformação na identidade pessoal de cada sujeito abale a figura do louco, essa identidade coletiva estigmatizada ${ }^{28}$.

A construção social da identidade é marcada por um contexto de relações de poder, o que significa dizer que quem constrói e para quê é construída que determinará o conteúdo simbólico das identidades coletivas. Desse modo, Castells (2006) diferencia três formas de identidades. Resumidamente, a primeira, identidade legitimadora caracteriza-se pela dominação internalizada, padronizada e nãodiferenciada introduzida pelas instituições dominantes da sociedade. A segunda, $a$ identidade de resistência, é criada por atores que se situam em posições

\footnotetext{
${ }^{28}$ Goffman (1963/1988) afirma que o conceito de identidade social parece ser o mais adequado para refletir sobre os grupos estigmatizados já que inclui atributos morais e estruturais que podem não aparecer nas discussões de status. Percebe-se, assim, que não há um consenso na literatura quando o assunto são as identidades. Cada autor lança seu olhar sobre a temática, muitas vezes apresentando discussões semelhantes, mas adotando terminologias diferentes.
} 
desvalorizadas ou estigmatizadas devido à lógica da dominação. São, portanto, manifestações contrárias às ideologias dominantes, uma identidade defensiva. Já a terceira, identidade de projeto, busca a transformação de toda a estrutura social através de sua redefinição na sua posição na sociedade. Penso que essa última é a que mais se adequa ao debate da saúde mental, sessa forma, o sujeito ${ }^{29}$ pode a partir de uma identidade oprimida construir um projeto de vida diferente e um nova sociedade a partir de seu novo lugar.

Esse movimento dá espaço para que grupos sociais historicamente subordinados possam afirmar suas experiências, valores e histórias, além de lutar pelos seus diretos civis. Felizmente, esses grupos vêm ganhando maior visibilidade, controlando espaços culturais que historicamente pertenciam aos grupos dominantes, como os jornais, os livros, os currículos das universidades, o cinema, a televisão e a internet. Em DSC2C vemos que há muito ainda o que ser conquista no campo da saúde mental: "O que acontece com a mídia hoje em dia? A mídia joga pra você como se você fosse obrigado a aceitar tudo o que ela está mostrando."

As mídias de massa também assumem uma lógica manicomial de funcionamento. Todo o poder econômico e simbólico estão concentrados em mãos corporativas poderosas que dispõem de recursos maciços para manter sob clausura a diversidade. As produções da indústria da mídia, privadamente controladas e desigualmente distribuídas, utiliza-se dispositivos ideológicos bastante refinados, para garantir que o mercado hegemônico continue expandido, sem que os subalternos percebam tal violência. (Soares, 2004)

Desenvolvendo ao máximo a absorção e o controle das diferenças, balizados por diretrizes da ordem do consumo, a televisão cuida de apresentar os conteúdos com manobras decodificadoras específicas, impedindo que o diverso questione o telespectador, "chocando minimamente os preconceitos socioculturais das maiorias". (Soares, 2004, p. 15)

O público, pelo fascínio e pela imersão na imaginação, mergulha no processo de simulação da realidade. O telespectador é dirigido pelo movimento reflexivo das representações televisivas, cujo material simbólico tende a extrair as possibilidades de produção de sentido. Entretanto, utilizando-se desse mesmo meio, compatível com o

\footnotetext{
${ }^{29}$ Para Castells (2006), sujeito é um ator social coletivo que corresponde ao desejo de ser indivíduo a partir da significação dada ao conjunto de experiências da vida individual. Desse modo para o autor sujeito não o mesmo que indivíduo.
} 
processo global, "as iniciativas dos meios de comunicação comunitária se consolidam pela possibilidade de promover a conscientização sobre suas causas, reivindicação de cidadania e mudança efetiva de sua realidade." (Soares, 2004, p.16). Debater o tema da saúde mental através de vídeos é boa uma estratégia para que a loucura tenha direito à enunciação, para que o imaginário da loucura seja tocado pelas imagens da diversidade. A tentantiva é conseguir o efeito "bola de neve", conforme enunciado em DSC2A, fazendo o discurso proliferar, aumentar seu alcance para torná-lo cada vez mais popular e conhecido por todas as camadas da população.

A democratização da comunicação, a apropriação dos meios massivos para a efetuação de comunicação das minorias, a invenção de novos sentidos e dispositivos de expressão singulares tem sido apontada como forma alternativa de operar frente à massificação estética e ideológica de padronização e homogeneização das sociedades, solidificada pela grande mídia. (Soares, 2004, p. 19)

A comunicação comunitária é veículo de expressão das lutas populares que buscam melhores condições de vida, é um instrumento político das classes subalternas comprometido com o projeto de sociedade mais igualitária e socialmente justa (Peruzzo, 2011). Sem dúvida, a força contra-hegenômica dessas iniciativas encontram resistências para adentrar o mundo televiso. Todo cidadão tem direito ao acesso à informação e aos canais de expressão, tem direito à mídias que vincule mensagens fidedignas e livres de preconceitos; todo cidadão e suas organizações coletivas podem ascender aos canais de informação e comunicação. Mas por que isso não acontece? A concentração da mídia nas mãos de grandes grupos econômicos e políticos decorrem de contingências históricas. (Peruzzo, 2011)

DSC3B: O problema de desigualdade social está desde quando surgiu o Brasil, ne? Nós vemos que as pessoas que vieram construir a Bahia eram de uma classe miserável, sofriam muito. Hoje eu dia eles colocaram essas construções como símbolo da humanidade. Porque agora eles querem mostrar essas pessoas, porque agora elas já morreram? Quando vivas, levavam chicoteadas, porradas, tendo que trabalhar forçado. Eram só pessoas que eram pobres que tinham vindo da África pra poder trabalhar como escravos, elas não tinham vindo pra poder ser uma sociedade. Onde é que está o amor dentro da nossa sociedade quando chega a esse ponto? A cidadania é dada pra pessoas de nível social, com descendência de determinada áreas, como de Portugal e vários outros países de renome para o Brasil. Mas as pessoas que vieram e tem a descendência africana aqui, não é uma pessoa bem vista, é mal olhada pela própria sociedade. A sociedade olha você com um olhar diferenciado, não te 
olham como se fosse um ser humano, elas te olham como se você fosse um ninguém, ne?

No primeiro trecho do DSC apresentado, o grupo revela uma análise profunda sobre tais questões, articulando as consequências do colonialismo histórico na formação da sociedade atual. A categoria "b", Preconceitos e opressão, compreende as raízes das desigualdades enquanto processo histórico, uma discussão muitas vezes ignorada até mesmo no meio acadêmico. De modo a desnaturalizar as marcas da colonialidade ainda tão vivas no cotidiano, o discurso denuncia a herança escravocrata e a banalização da violência. Assim como apontou Butler (2006), trata-se de rostos esquecidos, desumanizados, cujas mortes não deixaram vestígio.

A dominação formal do colonialismo político, em relação íntima com o poder capitalista, trouxe repercussões avassaladoras na forma como a cidadania é compreendida no Brasil. Ainda que a Constituição se utilize de um enunciado igualitário, ser cidadão - em seus plenos direitos, é para poucos. Vê-se claramente que todos os modos de existir que não servem ao modelo colonial poderão ser punidos de alguma forma. A hegemonia eurocêntrica assume uma supremacia determinante sobre todas as demais classificações e estabelece uma estruturas de poder, uma matriz estável, que opera como um tipo de poder disciplinar que se infiltra em todas as dimensões da vida.

A colonialidade deixou um legado de desigualdade, de injustiça social e um legado espistemológico do eurocentrismo, produzindo - através da razão - paradigmas distorcidos de conhecimento que impede qualquer compreensão do mundo que seja pelo próprio mundo, pelas suas epistemes próprias. (Quijano, 2007). A divisão entre o mundo da razão e o da desrazão, a criação das instuições totais, as classificações psiquiátricas, as relações de dominação, de controle, o desejo de subjugar, de oprimir apontam o estreito vínculo entre a colonialidade e a manicomialidade. Essa constatação fica mais evidente na segunda parte do DSC:

DSC3B: Esse negócio da discriminação que vem desde lá dos portugueses, e que varia desde a questão da cor da pele e evoluiu pra questão da saúde mental, evoluiu pra questão da loucura, do delírio, da incapacidade e tudo mais. Se em pouco mais de 500 anos não mudou muita coisa que deveria ter mudado, não vai mudar da noite pro dia também ne? Não vai acontecer de súbito, de repente cai do céu. 
A gente está num país muito corrupto, a classe dominante não favorece a área de saúde mental como deveria favorecer. Até pode ser criada uma lei que possa reverter esse quadro da saúde mental, reverter o atendimento psiquiátrico dos centros de saúde, só que assim...O sistema já está formado. A gente não deve depender como se a força viesse deles, daqueles que estão lá cima dominando no legislativo, no executivo, no judiciário. Como se a força viesse deles pra trazer essas mudanças que na verdade são muito radicais. Porque poder pra fazer eles sempre tem, por que eles não fizeram?

Então a gente depende de ONGs assim, com pequenas ideias, exercendo essa circularidade, pra tentar mudar mesmo a questão da identidade, do pensamento, quanto a questão da saúde mental, do potencial daqueles que tem algum transtorno. E aí a gente pega atividades assim como a tv sã, a Inverso ou os CAPS ou uma intervenção urbana; e a gente vai moldando, lapidando essa questão da percepção geral da sociedade contra a discriminação. Pequenas intervenções, ações, uma aqui, uma ali, isso vai mesmo divulgando o trabalho e aprimorando a questão da influência. que são coisas que mobilizam sociedades inteiras. Essas pequenas mobilizações assim, geram revoluções.

Analisando o discurso acima, vemos que a colonialidade no Brasil estabeleceu raizes históricas, configurou-se como uma matriz estável e duradoura de difícil regressão. A bandeira moderna que proclama a ordem e o progresso oculta o vermelho sangue da dominação. A pátria brasileira constituída por uma população analfabeta, uma sociedade escravocrata e uma economia monocultora e latifundiária não permitia que qualquer pessoa pudesse "adquirir" sua cidadania. Ao longo desses anos, vemos que o poder de corrupção já invadia os espaços públicos e privados muito antes da política do coronelismo. Não se pode saber ao certo a origem de todo esse desvirtuamento, mas seus efeitos são perceptíveis na vida de milhões de brasileiros - principalmente nos descentes que tiveram suas vidas escravizadas.

Ainda que a desigualdade social seja uma questão urgente, não existem soluções imediatas para nossos erros históricos, não há medida capaz de reparar esses erros. Do mesmo modo, aguardar que a representação política resolva os grandes problemas da maior parte da população também não é conveniente. Se estamos diante "de um sistema formado", de um Estado clientelista, corporativo e colonizado, as transformações não serão concedidas de cima para baixo, mas serão conquistadas por todos os lados. A dominação e a opressão não cessarão por vontade própria, mas pela vontade de justiça do povo e seu imenso esforço de articulação. A consolidação democrática depende do fortalecimento da organização da sociedade, de "pequenas mobilizações que geram revoluções". É essa ideia que conduz o trabalho da Tv Sã. 
Sem dúvida, a memória do grande enclausuramento nos ensinou que recorrer a soluções simples para lidar com problemas complexos pode provocar repercurssões desastrosas para a humanidade. Não há uma única solução para nossos problemas estruturais, mas existem outros caminhos que podem ser percorridos. Trata-se de uma descoberta processual, condicionada pelo momento histórico, pela organização econômica, levando em consideração a enorme diversidade cultural deste país de dimensões continentais. Se estamos propondo um projeto civilizatório democrático, é preciso reconhecer as particularidades de cada contexto.

Essa atenção também deve estar presente na Política Nacional de Saúde Mental, nas noções de rede e território que não podem ser pensadas de forma generalista. "Não é possível construir um modelo assistencial que sirva igualmente para as megalópoles e as pequenas cidades do interior" (Bezerra Jr, 2007, p. 244). É igualmente importante valorizar as experiências antimanicomiais brasileiras, não nos restringindo ao modelo eurocêntrico como sendo a única direção correta. Embora seja muito mais dispendioso criar novas estratégias em saúde mental, é importante investir tanto a criatividade quanto a afetividade nesses processos. O mero rearranjo despersonificado não persiste no tempo.

A busca por soluções rápidas aplicadas de forma padronizada não ocorre apenas no plano da gestão, mas refere-se a um modo de sociabilidade adaptado aos moldes do capitalismo. Na terceira parte de DSC3B fica evidente o impacto dessa lógica na subjetividade do sujeito.

DSC3B: Parece que a sociedade que a gente vive está condicionada a sair dos seus problemas rápido: "estou em depressão, aí fudeu, agora vou tomar o meu remédio antidepressivo", sendo que a pessoa já guarda aquele problema há anos, debilidades emocionais e tal. Só que falta um empenho, uma dedicação para a pessoa reverter aquele quadro que é tudo uma grande estratégia da consciência, da estrutura, da força de vontade, e a pessoa se apoia na questão da psiquiatria, da medicina e da constituição, sendo que ela tem em si mesmo o potencial da reversão de qualquer problemática subjetiva que a pessoa tiver. A sociedade ofusca esse potencial, ela veda, camufla.

A medicalização passa a fazer parte da vida do sujeito como recurso indispensável, sem o qual ele não é capaz de controlar suas emoções indesejáveis, especialmente aquelas que o tornam improdutivo para a sociedade. Depreende-se desse discurso que o sujeito alienado e dependente dos artifícios da psiquiatria, acaba se entregando aos saberes já institucionalizados - como da medicina e da constituição. $\mathrm{Na}$ busca apressada pela normalização, o potencial contido na problemática subjetiva 
nem chega a ser explorado pelo indivíduo. Ademais, se a indústria farmacêutica representa um fatia considerável na economia do mercado mundial, haverá patriocinador interessado em promover a autonomia do sujeito? Ao lado dos empresários dos grandes laboratórios, estão os empresários das grandes mídias, esbanjando os lucros obtidos às custas do sofrimento e da alienação da população. Enquanto isso, a distância entre as classes sociais só vai aumentando:

DSC3A: O louco rico tem possibilidade de cura bem mais rápido porque a família tem condições de pagar um tratamento de 5 estrelas pra ele. O louco pobre já tem uma condição precária: falta médico, falta remédio pra ele, ele não pode comprar todos os remédios. O governo não supre as necessidades básicas.

Tais dificuldades também são sentidas na Tv Sã: um participante assíduo, engajado no último projeto de vídeo, começou a faltar as reuniões. Ele vinha relatando a falta de recursos financeiros para ajudar em casa, pois sua mãe, já idosa, sofria com muitas dores no corpo demando remédios que muitas vezes não tinha na rede pública. Certa vez, com muita vergonha, ele perguntou se eu não poderia dar uma pasta de dente. Sem celular, sem telefone residencial, a única forma de contactálo era através do número da vizinha. Após várias tentativas frustradas, o grupo foi até o CAPS que ele costumava frequentar para tentar encontrá-lo. Descobrimos que ele não participava mais da Tv Sã, nem das oficinas do serviço. O grupo pediu para que a assistência social fizesse uma visita à sua casa pra saber se ele estava bem. O pedido foi negado.

Preocupados com o desaparecimento repentino do participante, o grupo foi bater na porta de sua casa. Naquele humilde lar, não havia campainha, não havia porta. O participante que procuráramos não estava em casa, sua mãe, uma senhora quase sem audição, demorou a perceber nossa presença ali. Parecia estar muito feliz com a nossa visita e aproveitou para desabafar sobre alguns problemas da comunidade. Não conseguíamos entender tudo que ela dizia e acabamos voltando sem a resposta da ausência do nosso participante, então o grupo deixou uma carta avisando sobre a visita e sobre a falta que sentíamos dele. Meses depois ele retorna para a reunião, e conta sobre o seu sumiço: não havia dinheiro para a passagem de ônibus. A resposta diante de nós a todo tempo.

Pensando nessa história, o grupo começou a traçar algumas perspectivas para 
um futuro breve da Tv Sã. Desse debate, surgiram algumas categorias: a) Profissionalização, emprego e renda para os usuários de saúde mental; b) Parcerias com estagiários; c) Resgatar as potencialidades de cada pessoa; d) Circular por outros espaços e promover a vida. Todos esses aspectos revelam, em alguma medida, o desejo em promover a autonomia dos participantes e impulsionar o trabalho da Tv Sã. Para tanto, devem ser feitas algumas adaptações ao modo de funcionamento do grupo para driblar a falta de recursos. Por exemplo:

DSC4A: Oferecer certificado para as pessoas se profissionalizarem lá fora, pois ganha uma experiência aqui e usa lá fora. Estou pretendendo chegar a um trabalho voluntário aqui futuramente com as oficinas de edição, é um trabalho gratificante, uma experiência que eu vou estar ganhando e lá fora poder me profissionalizar na área. Eu sempre quis dar aula um dia, quem sabe eu possa dar a partir da experiência daqui. Além disso, é necessário que o governo crie projetos dentro do DF para que essas pessoas que não tem emprego, elas possam alcançar alguma renda aqui. Se ela não tem renda e não estão querendo dar pra ela, tendo uma cooperativa, poderá ter sua própria renda e não depender do salário que o Estado fica sonegando o tempo todo. (...) Porque eu estou na sociedade, posso estar sem recursos financeiros nenhum, mas eu sou um cidadão igual a todos.

Certamente o grupo ainda não consegue realizar as expectativas de todos os seus participantes, entretanto, pequenas inovações poderão estimular o engajamento deles na Tv Sã e fora dela. A emissão de certificados pode ser um início: se para alguns o certificado não passa de um pedaço de papel, para outros é a materialização de seu esforço e seu reconhecimento. Ainda que as atividades realizadas na Tv Sã sejam profissionalizantes, há um espaço rico para trocas e desenvolvimento de habilidades. Os participantes vão se responsabilizando por certas funções específicas de acordo com os seus interesses.

Recentemente o grupo tem pensando em incluir programações atrativas que deverão ser assumidas pelos próprios usuários. A primeira, trata-se de uma oficina de edição de vídeo que já foi previamente organizada com um de nossos participantes. A segunda, refere-se a um cine clube, ainda sem nome definido, com a exibição mensal de filmes escolhidos pelo grupo. Ambas as programações serão dirigidas pelos participantes da Tv Sã, recebendo o suporte necessário. A incitação da autonomia e do senso de responsabilidade consigo e com com o grupo facilita a divisão de tarefas, mas, principalmente, reafirma o seu lugar de sujeito. 
Essa é uma questão fundamental, pois é o movimento de tomada de responsabilidade individual e coletiva que se constitui como meio para a transformação institucional e para o processo de desconstrução. O trajeto que compreende da saída da condição de sujeitado, um corpo marcado pelo exame clínico e pelo diagnóstico psiquiátrico, até a transformação em um usuário do sistema de saúde que luta para produzir cidadania para si e seu grupo passa necessariamente pelo aspecto central da autonomia. (Torre \& Amarante, 2001, p. 81)

Aos poucos, a noção de cura - ainda presente no discurso de alguns participantes - é substituída pela noção de autonomia, desconstruindo a relação de tutela e a percepção de si como um indivíduo incapaz. Através desses novos projetos, o grupo inventa espaços de saúde, de cultura, de produção de vida, e o trabalho coletivo contribui para potencializar esses focos de autonomia. Conforme aponta Costa e Medeiros (2009), numa perspectiva minkowskiana, a atividade $^{30}$ é um fenômeno essencial da vida, é "a alegria imediata de viver, apesar das perdas e dos fatores de limitação" (p. 379).

A atividade é, portanto, uma energia temporal, transformada em matéria que se funde com a abertura, com a potencialidade de contato com o meio ambiente, preenchendo um vazio repleto de possibilidades diante do indivíduo. É um fenômeno original e neutro, que muitas vezes parece ser suficiente em si mesmo, pois, em muitos momentos, o eu se deixa simplesmente viver, aproximando-se dos fenômenos da sintonia e do repouso, embora deles se diferencie. Em outros momentos, ela é atenção e tensão, uma energia concentrada, pronta para explodir na ação ou na sequência de ações, garantindo o ser e se identificando com a sua expansão. (Costa \& Medeiros, 2009, p. 380)

Essa energia vital tem uma duração ativa, uma sequência, uma coerência e finalidade das ações que constituem o tempo na vida do sujeito. Trata-se de uma vivência imediata, direcionada ao futuro. Entretanto, quando vemos o futuro e esperamos que ele se faça presente, estamos diante de um outro fenômeno temporal, no mesmo nível que a atividade, mas que a ela se contrapõe: a espera. Enquanto a atividade remete a um eu presente que enfrenta os limites e resiste às forças externas, a espera fixa o sujeito provocando uma sensação de angústia, de morrer próximo, suspendendo-o momentaneamente a vida. "Enfim, se na atividade o eu se estende nos espaços vazios, tornando-se quase um todo, na espera o eu é reduzido à mais simples

\footnotetext{
30 "Essa categoria foi vivenciada por Minkowski (1965) quando se encontrava em situação de risco no campo de concentração, e paradoxalmente, experienciava a alegria de ainda estar vivo." (Costa \& Medeiros, 2009, p. 370-380)
} 
expressão, ficando sob ameaça de ser engolido, tornando-se quase nada." (Costa \& Medeiros, 2009, p. 380)

É necessário portanto que essas duas categorias, atividade e espera, se equilibrem. Há uma tendência a esperar que a Tv Sã abra caminhos, que o governo dê oportunidades a projetos para que então seus participantes sejam valorizados. $\mathrm{Na}$ busca por um emprego, por exemplo, alguns experimentam com mais intensidade essa sensação paralisante de não ter domínio sobre o seu futuro. Ainda que esse sentimento possa ser interpretado como um mal-estar característico de nosso tempo, é preciso dar condições mínimas para que o sujeito possa estar envolvido nas atividades, já que antes, ele foi privado de todas elas.

A despeito de todos esses direitos negados pelo Estado e da impossibilidade atual da Tv Sã em proporcionar alguma renda aos seus participantes, eles não deixaram de se reconhecer como sujeito de direitos: "posso estar sem recursos financeiros nenhum, mas eu sou um cidadão igual a todos." São agentes de transformação que resistiram e continuam a resistem à opressão, lutando pelo seu espaço, pela sua saúde, por uma sociedade antimanicomial. A Tv Sã seria apenas "um trampolim" para voar mais alto e mergulhar mais fundo.

DSC4C: Eu acredito em uma grande melhora, em um grande benefício por diversos recursos. Eu tenho a oferecer possibilidades de ajudar. A Tv Sã pode ser um trampolim para divulgação, para um alerta, não somente na área da cura $^{31}$ interior, subjetiva, potencial inerente da pessoa, mas a Tv Sã pode abordar diversas áreas voltadas para a saúde mental: do direito, da questão do preconceito, da inclusão, da inserção social, tanta coisa. É um trampolim pra muita coisa.

Trabalhar com vídeos permite comunicar de modo mais eficiente a mensagem dessa luta em todos os campos transversais ao da saúde mental, desterritorializando a discussão sobre a desinstitucionalização. De posse de uma ferramenta tão potente, como a Tv Sã pode alcançar seus objetivos de modo mais incisivo? Nesses sete anos de percurso, o grupo consegue perceber seus avanços, entretanto, o sentimento de

\footnotetext{
${ }^{31}$ Interessante notar que o termo "cura" ainda é um conceito presente na fala de alguns usuários, talvez porque ainda esteja presente na fala de alguns profissionais. "A cura cede espaço à emancipação, mudando a natureza do ato terapêutico, que agora se centra em outra finalidade: produzir autonomia, cidadania ativa, descons- truindo a relação de tutela e o lugar de objeto que captura a possibilidade de ser sujeito. (Torre \& Amarante, 2001,p. 18)
} 
espera parece estagnar as suas ações. Com um número reduzido de participantes voluntários, apenas um notebook servindo como ilha de edição, filmagens realizadas numa câmera fotográfica ou num celular, mostram que a falta de recursos, muitas vezes, torna a tv comunitária pouco interessante aos recém-chegados. A boa vontade e as boas ideias do grupo atraem novos participantes, mas com o tempo, muitos acabam desistindo do projeto.

No período inicial da Tv Sã, quando ainda estava integrada ao projeto de extensão do UniCEUB, alguns estudantes vincularam-se ao grupo. Alguns permaneceram durante até o final do semestre para cumprir a carga horária obrigatória, outros permaneceram até o final da graduação e, assim que formaram, seguiram seu próprio caminho. Naturalmente, alguns eram mais engajados que outros, mas todos acabaram deixando o grupo por diferentes motivos. Certamente essa impermanência de um núcleo fixo de trabalho produz um impacto no grupo. $\mathrm{Na}$ entrevista grupal, o assunto veio a tona, organizado na categoria "b", parcerias com estagiários:

DSC4B: A Tv Sã precisava de, não sei se é estímulo, o que é, porque as pessoas não podem ficar o tempo todo ali, um grupo só. As outras pessoas que passam pra ajudar, elas não dão conta de ficar por um ano ou mais. (...) Por exemplo, as pessoas que vem na Inverso pra fazer um estágio, eles tem um compromisso aqui. E aí na tv sã seria a mesma coisa, um compromisso - mas não verbal, por escrito - de pessoas de diversas áreas pra dar a sua contribuição, mas estar vinculado ao compromisso que irão ficar, vamos dizer, 6 meses. Depois entrariam outras pessoas. Talvez seja por isso que essas pessoas não ficam. Foram embora com seus problemas e tudo, acabaram saindo, não que não gostassem, mas é porque não tinham condições de assumir o tempo todo. Por outro lado, é interesse que as pessoas se aproximem de forma mais natural.

Devido à necessidade de um estímulo para a Tv Sã, o grupo apontou os prós e os contras da parceria com estudantes de diversas áreas. A exemplo da Inverso, percebeu-se que a presença de estagiários pode contribuir para o funcionamento da instituição, aumentando as trocas e a força criativa nas oficinas. A condição do estágio determina que o estudante deve cumprir uma carga horária no local, devendo apresentar documentos comprobatórios de sua presença na ONG durante, pelo menos, um semestre. Geralmente, o estudante, supervisionado por um professor, também deve produzir um relatório sobre sua experiência que contará como uma menção na disciplina cursada. Assim, o estagiário assume um compromisso com a Inverso e com 
a sua universidade. A vantagem desse tipo de acordo é dinamizar o trabalho do grupo e registrar continuamente as atividades desenvolvidas.

Deve-se considerar, entretanto, que nem sempre o cumprimento da carga horária no estágio revela um comprometimento do estudante com a proposta da $\mathrm{Tv}$ Sã, afinal, a obrigatoriedade da presença física no local não garante a disponibilidade para os outros efetivamente. Nesse sentido, tal exigência poderia afetar a qualidade das relações, produzindo uma artificialidade na convivência. Conforme apontou Elias: "apareceram alguns estagiários, só que eles só queriam saber a história da tv sã, não queriam participar (...). Foi passando o tempo, eu continuei não gostando e eles perceberam que aquilo não estava sendo muito agradável e deixaram a tv sã."

Desse modo, o grupo deveria preparar-se para duas situações: quando o estagiário não se vincula e quando o estagiário se vincula. No primeiro caso, é importante considerar que o grupo não deve tomar para si toda a responsabilidade da não-vinculação do estagiário, posto que tal dificuldade pode estar relacionada à questões pessoais do estudante, como por exemplo, a falta de interesse no campo de atuação escolhido. No segundo caso, o grupo deveria lidar com uma nova circunstância imposta pelo estágio, a alta rotatividade de participantes, como Léo descreveu:

Em questão da saúde mental lá no CAPS, por exemplo, os estagiários e estagiárias pegam amizade com todos os pacientes e a gente acaba tendo um momento de se despedir porque fica um semestre, 2 anos no máximo. Chega aquele momento de despedida todo mundo fica triste, chateado (...).

Desse modo, os encontros e as despedidas passam a ser encarados de modo natural, sem que o sujeito sinta-se abandonado. Perceber o caráter passageiro (e não descartável) da vida é oferecer liberdade para o outro e para si, é romper todos os lugares fixos que as instituições nos impõem. Em contraposição ao sujeito institucionalizado, o sujeito em movimento pode transitar para além dos caminhos alternativos, ele cria seus próprios caminhos. Assim, suas responsabilidades no grupo não podem se tornar um peso, mas um impulso para o seu crescimento: "esses dias eu estou indo fazer curso pra poder, ano que vem, prestar vestibular. No entanto, quando eu prestar vestibular, se eu passar, eu não vou estar vinculado totalmente à tv sã", disse Elias. 
O espaço da Tv Sã não é, nem deve ser uma preocupação ou um fardo para seus participantes, pelo contrário, a produção de vídeo deve ser como uma brincadeira. Nesse tipo de atividade lúdica é possível explorar uma liberdade incrível de tempo e espaço e uma nova conexão entre o eu e o mundo por meio de uma linguagem espontânea e de corpo inteiro. Dessa maneira, "brincar de vídeo" é a própria afirmação da vida, é extrair a leveza e a alegria em histórias marcadas pelo sofrimento. Se desde nossos primeiros contatos sociais, a brincadeira é um modo como o sujeito se apropria do espaço, então devemos recuperar esse aspecto lúdico para o cotidiano - especialmente para aqueles que tiveram uma infância de pouco brincar em razão do trabalho precoce ou demais obrigações.

Sobre esse tema trabalhado durante as entrevistas grupais, criou-se a categoria "espaço lúdico, debate sério" subdividido em: a) O humor como recurso para superar o sofrimento; b) O humor como estilo de crítica.

DSC5A: Eu costumo brincar muito com o meu surto. Quando eu comecei a surtar parecia um pesadelo que eu via na minha frente, hoje em dia eu dou risada das neuras que eu tive e tal. A gente deve tratar a saúde mental com espontaneidade, como que se não levasse a vida tão a sério, sabe? Mas nem tudo é só brincadeira, há o medo, o desespero, o constrangimento, mas se não levar na brincadeira a gente acaba sofrendo o tempo todo. Tudo que você faz com rigor, com aquela regência militar traz um negócio negativo. Por exemplo, a gente fazer sátiras do governo e discutir com humor o lado mau, das trevas, que rola dentro dos CAPS ou que rola dentro do HSVP - não que seja motivo de piada, claro, mas tratar com naturalidade, com uma postura descontraída - favorece mais do que você atirar pedra. Tem coisa que realmente você tem que apedrejar. (...) Aí se você vai criticando ou apontando as falhas, os defeitos com uma austeridade muito grande, uma opulência, acaba que o rendimento da discussão vai ser inferior. Com espontaneidade, com senso de humor, é tudo de bom.

Nesse DSC o humor surge com um importante recurso que atua em dois níveis simultaneamente: individual e institucional. No primeiro momento, o humor funciona como uma ferramenta para ponderar todas as emoções vividas em torno do sofrimento intenso, ressignificando o momento da crise, sem deslegitimá-lo. Provavelmente, a descoberta do humor requer do sujeito um tempo de calmaria para que ele possa elaborar o queimor de sentimentos que foram desencadeados. "O cômico parece só produzir o seu abalo sob condição de cair na superfície de um espírito tranquilo e bem articulado." (Bergson \& Castilho, 2007, p. 7). Significa dizer, que o sujeito passa a se ver como um espectador neutro assistindo sua própria vida, convertendo seus próprios 
dramas em comédia, num tipo de manejo existencial para ver, a partir de fora, a alma do personagem de si. "Portanto, o cômico exige algo como certa anestesia momentânea do coração para produzir todo o seu efeito." (Bergson \& Castilho, 2007, p. 8)

quando certo efeito cômico derivar de certa causa, quanto mais natural a julgarmos tanto maior nos parecerá o efeito cômico. Rimos já do desvio que se nos apresenta como simples fato. Mais risível será o desvio que virmos surgir e aumentar diante de nós, cuja origem conhecermos e cuja história pudermos reconstituir. (Bergson \& Castilho, 2007, p. 8)

Se por um lado a comicidade é uma característica propriamente humana, por outro, o cômico requer uma certa indiferença e o riso, a retirada da comoção. "Mostrem-me um defeito por mais leve que seja: se me for apresentado de modo a comover minha simpatia, ou meu temor, ou minha piedade, acabou-se, já não há mais como rir dele" (Bergson \& Castilho, 2007, p. 67) Sendo assim, até que ponto esse recurso pode ser interessante? Rir com, rir de, rir para? "Qual é a intenção da sociedade quando ri."? (p. 97)

Vale lembrar ainda que nem sempre uma narrativa bem-humorada sobre os fatos indica que o sujeito está bem, ao contrário, ele pode apenas estar correspondendo a um fundamento moral da felicidade, criando para si uma obrigação psicológica - típico na sociedade de hiperconsumo. Sendo assim, entendo o humor não como um recurso individual de resiliência, mas um aspecto indissociável do social que deve ser explorado. O riso tem uma significação social e o cômico certa inadaptação particular da pessoa à sociedade. A comicidade não existiria se estivessemos isolados, ela é essencialmente social. Vê-se aí uma questão embaraçosa: com o riso insinua-se a intenção inconfessada de humilhar e de corrigir. (Bergson \& Castilho, 2007)

Uma vez que eu comentei com um amigo meu bem assim "ah, eu tenho alucinações". Aí ele falou "Nossa, deve ser muito massa ter alucinações, você está num lugar e vê uma pessoa que não existe e começa a conversar sozinho". Aí eu: "é, é muito massa, é muito doido", mas por dentro eu fiquei constrangido com aquilo."

Através dos estudos de Bergson e Castilho (2007), é possível reconhecer as várias facetas do riso, nem sempre ele é justo ou benevolente. "A sociedade vinga-se através do riso das liberdades que se tomaram com ela. Ele não atingiria o seu 
objetivo se carregasse a marca da solidariedade e da bondade." (p. 92). Ele reprime a manifestações dos desvios e incita a correção dos "defeitos" ao ressaltar as ondulações que surgem na superfície da sociedade. De forma bastante poética, os autores descrevem a complexidade desse fenômeno com uma metáfora sobre o mar:

É assim que as vagas se batem sem trégua na superfície do mar, enquanto as camadas inferiores conservam uma paz profunda. As ondas se entrechocam, se opõem, procurando equilíbrio. Uma espuma branca, leve e alegre segue-lhe os contornos cambiantes. Às vezes a onda que foge deixa um pouco dessa espuma na areia da praia. (...) $\mathrm{O}$ riso nasce assim como essa espuma. Ele assinala, no exterior da vida social, as revoltas da superfície. Ele desenha instantaneamente a forma movente desses abalos. É também uma espuma salgada. Como a espuma salgada, ele crepite. E a alegria. O filósofo que a toma nas mãos para sentir-lhe o gosto há de encontrar por vezes, numa pitada de matéria, certa dose de amargor.

Tal metáfora traduz o exato gosto das produções da Tv Sã. O humor dos vídeos chega como uma onda de emoções, por vezes conflitantes: coragem, impotência; alegria, desânimo; alívio, exaustão. Em meio a essa agitação, o humor se descobriu como um estilo de crítica. Percebe-se assim, que o plano individual está inteiramente articulado ao plano social, só que, em vez do indivíduo ser apontado, é ele que apontará os desvios institucionais.

DSC5B: Ser crítico foi uma coisa que eu aprendi na Tv Sã. (...) Muitos acham que é só um vídeo brincalhão, mas ela não faz só brincadeiras, ela mostra exatamente a realidade do fato, de modo crítico. (...) A Tv Sã é acusadora mesmo, aponta aquilo que não estava servindo no serviço público. Mas falta as pessoas pensarem "nós precisamos melhorar". Se não tiver mais pessoas pra nos ajudar, nós não vamos conseguir ir dar a cara a tapa. Só que ninguém quer ir dar a cara a tapa.

Assim como foi mostrado no DSC5A, o humor é uma estratégia para que a discussão sobre o "lado mau" dos serviços seja explorada da melhor forma possível. O modo brincalhão como a Tv Sã conta as histórias, o exagero na interpretação, a troca de papéis entre médico e paciente, são artifícios para dar leveza e destaque aos temas e à denúncia. O humor, enquanto estilo de crítica, utiliza a espontaneidade a seu favor para deixar o participante mais à vontade para se expressar, afinal quem quer "proto- 
agonizar" ${ }^{32}$ ? Para romper com o silêncio e a alienação:

o resgate da dimensão heroica de pronunciar-se em um confronto público que o termo protagonismo guarda - requer a constituição de espaços em que os usuários possam experimentar a capacidade de pensar, sentir e decidir sobre suas vidas singulares em meio ao coletivo que constituem e que os constitui subjetivamente. (Costa \& Paulon, 2012, p. 581)

Dessa forma, a insurgência do coletivo é um dispositivo inclusivo e participativo capaz de potencializar a criticidade e o exercício de protagonismo do usuário de saúde mental. A força e a proteção desse coletivo reafirma a possibilidade do sujeito se enunciar, encorajando-o a ser o ator principal da transformação social ainda que a instituição psiquiátrica tenha tentado persuadí-lo do contrário. No seio de uma sociedade excludente e individualista, ecoa a denúncia mais contundente: "nós precisamos melhorar".

\footnotetext{
32 "Para a dramaturgia grega, ser o protagonista sinalizava ser o primeiro a entrar em cena. Por isso, ainda hoje, a etimologia da palavra protagonista guarda algo dessa disputa, pois 'proto' significa primeiro, principal, e 'agón' significa luta, disputa, discussão. O primeiro a falar na 'ágora' grega, portanto, o 'protoagonista', é justamente aquele que anuncia o que se irá discutir, o primeiro a pôr aquilo que está em disputa, em discussão, em cena. Não será mesmo isso - aquilo que não pode calar - que o usuário da saúde mental anuncia em sua demanda/agonia participativa? O que 'precisa' ser posto na roda?" (Costa \& Paulon, 2012, p. 577)
} 


\section{CAPÍTULO V - NOVAS TERRAS À VISTA}

\section{1 - Do corpo invisível ao corpo televiso}

No cenário contemporâneo, todos nós estamos implicados nas lógicas midiáticas, é nesse campo que as visibilidades e enunciabilidades são negociadas. Sobre a saúde mental o que está em jogo vai muito além do questionamento da limitada caricatura de um alienismo branco e sem miséria que aparece na tv de massa. Essa questão aponta para uma ampla alienação de todos nós, de todos os espectadores presos a um estado de contemplação em que "quanto mais ele contempla, menos vive; quanto mais aceita reconhecer-se nas imagens dominantes da necessidade, menos ele compreende a sua própria existência e o seu próprio desejo." (Debord, 1997, p. 19)

Não cabe aqui fazer um julgamento moral sobre as posições de protagonistas e espectadores, nem cabe polarizar os sujeitos em ativos e passivos como formas rígidas de ser. Este trabalho se propõe em fazer justamente o contrário, produzir movimento e diminuir a distância entre ator e platéia, fazendo com que todos participem do processo. Se de um lado temos a tv de massa que visa o sujeito consumidor e, do outro, temos a tv comunitária que promove o sujeito cidadão (Miranda, 2007), em todos os lados temos a imagem. É a imagem que circula fora dos confins, é através dela que nós podemos evadir os sentidos e revelar a fragilidade da norma. Ainda que não se possa libertar ninguém do enclausuramento, ela pode denunciar o sistema publicizando seus métodos violentos de um pensamento desraizado da vida.

Ciertos rostros deben ser admitidos en la vida pública, deben ser vistos y escuchados para poder captar un sentido más profundo del valor de la vida, de toda vida. Así, no es que el duelo sea la meta de la política, pero sin esa capacidad para el duelo perdemos ese sentido más profundo de la vida que necesitamos para oponernos a la violencia. (Butler, 2006, p. 21)

Assim, concluo que para alcançarmos a almejada "nova imagem da loucura", devemos antes questionar todos os limites do campo de visibilidade publicamente reconhecido. A questão é óbvia: a violência só poderá ser interrompida quando for percebida como violenta, a humanização nos serviços só acontecerá quando a expressão de sofrimento puder ser percebida em qualquer rosto humano, independentemente de sua cor, classe ou gênero. O resgate desse valor profundo da vida passa por um processo de sensibilização que rejeita todas as categorizações estigmatizantes que limitam a compreensão das realidades. 
Tal como o cinema, as realidades jamais se encerram, é um campo aberto. Entender o sentido de imagem depende daquelas que a precedem e daquelas que a sucedem, mas não equivale apenas a uma soma de elementos empregados, é mais que isso, é uma forma temporal. O filme surge, então, como uma forma extramente complexa, em que numerosas ações e reações se expressam a cada momento. Assim, como a realidade transborda ao pensamento, "le film ne se pense pas, il se perçoit" (Merleau-Ponty, 1996/2009, p. 22)

Segundo o pensamento bergsoniano, apresentado na obra de Merleau-Ponty, o real pode ser conhecido de duas formas: A primeira por um método científico de decomposição, de análise da sucessão de momentos estáveis, um princípio que, apesar de analítico, aniquila o movimento, o real como uma atualização de um possível. A segunda forma - que mais nos interessa - é a atenção dada ao aspecto criativo do real, à sua duração, conhecendo o devenir das coisas. Observando tais formas, o autor afirma, "le mécanisme de notre connaissance usuelle est de une nature cinématographique" (Merleau-Ponty, 1996/2009, p. 59) ${ }^{33}$. Mesmo reconhecendo que o cinema não teria a capacidade de reproduzir a trama viva da experiência vivida: "il nous offre directement cette manière spéciale d'être au monde, de traiter les choses et les autres, qui est pour nous visible dans les gestes, le regard, la mimique, et qui définit avec évidence chaque personne que nous connaissons." (Merleau-Ponty, 1996/2009, p. 22-23)

A percepção de tais condutas visíveis, os fatos psíquicos e os sinais corporais, nos remetem a um campo visual. Segundo Merleau-Ponty (1996/2009), a psicologia clássica por muito tempo determinou tal percepção como uma decifragem que passa pela inteligência, em que os signos que nos são dados são lidos e interpretados. O campo visual funcionaria como um mosaico de sensações estritamente determinadas pelas excitações na retina. Enquanto a psicologia clássica tem a tendência de absolutizar os cinco sentidos isolando-os, a nova psicologia considera um "sistema de configurações". A percepção não se refere a uma soma de sensações, mas ao reconhecimento dos significados, das formas que se comunicam umas com as outras. Merleau-Ponty (1996/2009), ao relembrar o desejo de Cézanne em pintar o cheiro das

\footnotetext{
${ }^{33}$ Ainda que o cinema seja um processo distinto da produção de vídeos no contexto de um tv comunitária, considero pertinente trazer tais reflexões contidas na obra Le cinèma et la nouvelle psychologie (1996/2009).
} 
árvores afirma:

"poder pintar o cheiro das árvores". Fantasia de artista? De forma nenhuma. Nós não deixamos de qualificar nossas impressões reconhecendo-as de um modo misturado. Esta cor nos parece "quente" ou "fria", aquelas soam como "aguda, brilhante, áspera ou macia" (...). "Eu percebo de uma maneira indivisa, com todo meu ser, eu compreendo a partir de uma estrutura única, uma maneira de existir que remete a todos os meus sentidos ao mesmo tempo." (Merleau-Ponty, 1996/2009, p. 41, tradução da autora)

Para o autor, o corpo é fonte de sentidos em que o pensamento e a ação correspondem a uma única unidade. O olho olhando, a mão gesticulando, não são reproduções mecânicas, não é mais em-si ou puramente tético, são pensamentos em plena realização no mundo, um movimento de transcedência. "A nossa ação é geradora de sentidos. Por isso ela pertence à dimensão da poiesis, da criação, é tessitura de expressividade." (Peixoto, 2014, p. 320) O corpo enquanto, natureza e cultura, não é mais mera passividade ou inércia, ele exerce um papel de mediação entre nós e o mundo.

Segundo Peixoto (2014), as concepções merleau-pontianas sobre corpo e existência apresentam um sentido formativo que rompe com as as concepções que dicotomizam o homem e o conhecimento e empobrecem a compreensão de mundo. Em sua análise sobre o fazer pedagógico, o autor reconhece na obra de Merleau-Ponty a sua grande importância para a descolonialidade:

é uma importante contribuição para que a pessoa desenvolva as suas próprias habilidades corporais e intelectuais, como processo de libertação da alienação, das ideologias, do consumismo, dos preconceitos e como afirmação da liberdade e da autonomia da pessoa. (p. 323)

Nesse sentido, a produção de vídeos, também nos remete a um fazer pedágogico, a uma formação aberta que valoriza o desenvolvimento do corpo, da sensibilidade artística e cultural, do espírito da crítica e da criatividade. É por meio das imagens que reaprendemos a ver o mundo em contato com a superfície do nosso ser. Para tanto, parto da compreensão de que a percepção visual não está vinculada a um pensamento de ver, mas a uma percepção, pois "quando eu percebo, eu não penso o mundo, ele se organiza diante de mim"(Merleau-Ponty, 1996/2009, p. 43, tradução da autora).

Segundo Soares (2004), o recurso de de dirigir-se e utilizar a imagem ganha 
dimensões essenciais no debate da saúde mental. Para a autora, a particularidade simbólica na(s) psicose(s) é marcada pela ruptura da partilha dos códigos sociais e pela desintegração psíquica, dessa forma, os recursos televisivos indicam uma possibilidade de remediar tal o percalço simbólico justamente por oferecer uma ancoragem possível.

Estudos de casos que inferem a ocorrência de um processo de estabilização psíquica através do uso do recurso da reprodução televisiva insinuam que tal recurso pode acenar para alguns sujeitos como "empréstimo" de elementos dos quais estruturalmente acham-se desprovidos. O recurso televisivo (ver-se projetado, aperfeiçoar a forma de exposição, elaborar textos, entrevistar, filmar, etc.) pode constituir-se em objeto capaz de dar consistência à imagem corporal, conferindo contornos ao corpo imaginado em fragmentos, através do centramento e da circunscrição da imagem televisiva (Soares, 2004, p. 18)

Esse trabalho de dar consistência à imagem corporal, pela sua própria significação e nomeação, "estaria acenando a 'tomada de enunciação' pelo sujeito, 'descompletando', assim, o saber absoluto do Outro a seu respeito." (p. 18). Soma-se a isso, a dinâmica de formação do processo grupal na prática comunitária que promove um de intercâmbio com a realidade e de reconstrução da imagem da loucura. Utilizar tais recursos em grupo abre espaço para uma gestão reinvidicatória, uma engrenagem importante para construção de uma cidadania intermediada pelo viés comunitário. É por meio da interação grupal, do dispositivo comunicacional, e da abertura a um um formato institucional que "não sabe" previamente que permite que o sujeito experimente a construção de um novo saber, um saber próprio. (Soares, 2004)

Alguns autores categorizam os quadros psicóticos como "doenças da comunicação" em função das alterações de linguagem, como por exemplo, os neologismos patológicos, as estilizações, os rebuscamentos, a salada de palavras. "Seria, então, um paradoxo proferir a convocação continuada desses sujeitos à participação no processo social mediante os mecanismos comunicacionais?" (Soares, 2004, p. 14). Certamente não. Conforme vimos no trabalho desenvolvido pela Tv Sã, essa inclusão do dispositivo grupal na esfera comunitária é o ponto chave para o caminho da desinstitucionalização.

A apropriação dos meios massivos e hegemônicos para comunicar a diversidade, é uma manobra estratégica para a democratização e protagonismo em que a linguagem televisiva é capaz de articular os meios globais com a participação local. 
Entretanto, "o empoderamento da mídia pelas classes populares é uma ousadia que exige o rompimento de entraves históricos e conjunturais de diferentes matizes." (Peruzzo, 2008, p. 178). Assim como a Tv Sã, a primeira Tv comunitária não era um canal de televisão, era apenas uma produção audiovisual exibida em praças públicas, sala, postos de saúde. A operacionalização desse tipo de tv atua no contra caminho da espetacularização, ela tem como finalidade a introdução de sentido - e não seu desfalecimento.

A situação dos canais comunitários é a mesma e a Tv Sã não foge a regra. Todas são criadas pela vontade mobilizadora de organizações locais sem fins lucrativos, mas enfrentam graves dificuldades para obter recursos para sua instalação, equipamentos, operação e manutenção, já que não encontra apoio do poder público para a sua realização, pois não se enquadra da lógica do mercado, nem depende de altos índices de audiência para operar. (Peruzzo, 2008) O foco está na força da participação social.

entendemos a participação social enquanto processo de afirmação de singularidades possíveis, forjado nos encontros, parcerias, embates e discussões que se dão no cotidiano do trabalho em saúde, tanto nos espaç,os instituídos formais, criados para que as pessoas participem levando suas reivindicações e delegando poderes, quanto nos encontros que compõem o dia a dia da vida de um usuário da saúde mental (...) (Costa \& Paulon, 2012, p. 576)

Entretanto, conforme nos alerta Soares (2004), não podemos imergir na "concepção de um triunfalismo" acreditando que a simples introdução de um meio popular seja algo essencialmente libertador. A luta é contínua: se a tendência é a reprodução de valores ideológicos, e não a sua transformação, precisamos avaliar constantemente os processos de comunicação em torno dos interesses coletivos dos sujeitos, especialmente aqueles que foram invisibilizados.

As atividades incessantes de questionamento e mobilização para a transformação do paradigma manicomial devem explorar todos os recursos que tem e os que não tem - à sua disposição. A saída da condição de usuário-objeto e a criação de formas concretas que produzam um usuário-ator, sujeito político depende de uma construção coletiva de protagonismo. Segundo Torre e Amarante (2001), uma das necessidades atuais é a de compor uma rede de comunicação capaz de fortalecer as 
trocas e os debates. Assim, concluo que um forte dispositivo de desinstitucionalização é a comunicação comunitária. Tornar o invisível televiso é legitimar outros modos de ser, é interferir no campo político. Desse modo, desinstitucionalizar é democratizar as mídias, é poder ver-se existindo e atuando no mundo como sujeito de direitos.

Por fim, a comunicação comunitária no Brasil, e no seu interior, a televisão comunitária, vem contribuindo para gestar um novo modelo de comunicação pública, o público-popular. Novo por que não se trata do modelo públicoestatal, nem o público de alta cultura, nem o educativo-cultural controlados pelos governos, por órgãos de gestão com representação civil e/ou pública ou por grupos privados, respectivamente. É uma comunicação que parte da sociedade civil, no âmbito das organizações comunitárias e de outros matizes, voltadas para o desenvolvimento social e ampliação do exercício da cidadania. (Peruzzo, 2008, p. 186)

5.2 - Cidadania ampliada: uma construção coletiva

O campo artístico-cultural representa mais que um potencial terapêutico, é um recurso de desenvolvimento político. O usuário de saúde mental ao recusar a identidade deteriorada que lhe é imposta e reivindicar sua posição como artista ou como participante de um projeto social, está comunicando à sociedade que também é sujeito de direitos. A Tv Sã é um projeto comunicacional que faz uma pequena diferença na vida de algumas pessoas - e não há nada maior que ver essas pequenas mudanças acontecendo.

Seria muito pretencioso acreditar que a psicologia ou a psiquiatria poderia dar voz ao usuário, se por muitos anos foram esses saberes que calaram os gritos de sofrimento, que puniram os corpos em prol de um projeto colonizador/moderno. Um ato de remediação não encobre o desejo manicomial aferrado às nossas relações. Portanto, a voz não deve ser dada, concedida ou devolvida aos usuários de saúde mental porque ela não deve estar submetida ao tempo da psiquiatria ou à maneira da psicologia. Não cabe nós regular o tom, cabe a todos nós escutar e compreender.

O próposito desse estudo foi exatamente este: escutar o discurso de uma tv comunitária em saúde mental. O uso da metodologia do Discurso do Sujeito Coletivo foi uma ferramenta importante para sistematizar essas falas e dar unidade ao grupo, entretanto, entendo que a construção dessa informação esbarrou em alguns limites que podem ser explorados em estudos posteriores. Tendo em vista que os usuários de saúde mental não correspondem à totalidade dos participantes da Tv Sã, há de se 
considerar que a expressão do pensamento coletivo também compreende as impressões dos familiares e estudantes. Do mesmo modo, entre os próprios participantes-usuários, há diferenças de cor, classe e escolaridade que, em alguma medida, trazem influências que poderiam ser escutadas de forma mais aprimorada. Levando em consideração o pequeno número de participantes e o curto prazo para a pesquisa, considero que a metodologia escolhida cumpriu o seu papel satisfatoriamente. Todavia, como a produção de conhecimento é um campo aberto, proponho para os próximos estudos a análise dos diversos tipos de sujeitos coletivos de modo a tornar mais evidente as nuances dos discursos dos usuários, dos familiares, dos estudantes, dos profissionais, dos artistas, entre outros.

Enquanto pesquisadora, entendo que o propósito dessa investigação cumpriu com os objetivos propostos. Enquanto integrante do projeto, fiquei surpreendida com a profundidade do debate que revelou facetas completamente novas sobre a dinâmica da Tv Sã. Analisar a constituição desse coletivo e o processo histórico e político subjacente fomentou ainda meu interesse em compreender como funcionam as engrenagens da colonialidade, modernidade e manicomialidade, especialmente na América Latina. Entender como se configura esse sistema de razão é uma forma de conhecer as ferramentas que temos disponíveis hoje para interromper essa lógica excludente de interdição do olhar à alteridade.

Dar visibilidade a essas questões é um dos objetivos da Tv Sã. Em tempos líquidos temos o retorno à convivência, aos afetos, aos vínculos de amizade. Para a reprodução da ideologia dominante, há a resistência, a expressão cultural. Diante de uma ordem social injusta, existe o reconhecimento do sujeito da diferença como sujeito de direitos. São esses caminhos que estão sendo experimentados nesse projeto, caminhos de liberdade. A busca pelo crescimento e pela autonomia dos participantes, a troca de conhecimentos para superar os obstáculos relacionados ao sofrimento ultrapassa o próprio grupo. Também é interesse do projeto incluir toda a sociedade no debate da saúde mental, questionar a representação estigmatizada da loucura na tv e incentivar a diversidade nas mídias.

O discurso coletivo da Tv Sã aponta a importância de articular o aspecto micro e macro das relações, pois para resgatar as potencialidades de cada pessoa é preciso garantir livre acesso a outros espaços sociais, é preciso, finalmente, ocupar a cidade. 
Se desde a nau dos loucos até os hospitais psiquiátricos a prática de marginalização vem sido naturalizada e perpetuada através de muros simbólicos, a desmontagem das identidades sociais estigmatizadas passa obrigatoriamente pela problematização do preconceito, da opressão, das desigualdades em suas dimensões subjetivas e sociais.

Tendo em vista que a luta antimanicomial é um movimento social amplo que combate todas formas de violência, sabemos que com a mera concessão de direitos como é típico da cidadania - não irá abolir as relações de dominação. Estamos diante da necessidade de uma reconversão global dos processos de socialização, afinal, o processo de desinstitucionalização é social. Refletindo sobre o conteúdo da entrevista grupal, ficou ainda mais evidente que o exercício individual de uma consciência cidadã, não rompe com as formas de vida institucionalizadas e com a sujeição fundante da sociabilidade capitalista. (Alverga \& Dimenstein, 2006)

é limitada a luta pela reforma psiquiátrica calcada na perspectiva da reinserção social, busca pela reafirmação dos ideais modernos de liberdade, igualdade e fraternidade, sem uma crítica (ruptura) radical aos fundamentos de um processo societal que se desenvolveu ancorado na rejeição de tudo o que não se identificava com a racionalização da vida cotidiana. (Alverga \& Dimenstein, 2006, p. 302)

Os autores alertam sobre os embaraços do paradigma da reabilitação psicossocial, um princípio tão presente nas reinvindicações dos tantos dos técnicos quanto dos usuários. O que há por traz da ideia? "A culpabilização do indivíduo colocado à margem, bem como uma avaliação da falta de adequação social e necessária adaptação ao que lhe marginalizou" (Alverga \& Dimenstein, 2006, p. 303). O termo reabilitação traz, em si mesmo, controvérsias: (re)habilitar seria voltar ao que se era antes? Como podemos reabilitar uma ruptura fruto de um desencadeamento psicótico, quando a estrutura do sujeito não será mais a mesma? Estaríamos apostando num retorno a um suposto estado anterior e desconsiderando a possibilidade de aprendizado de novas estratégias? (Guerra, 2004)

Segundo Guerra (2004), apesar de hoje a reabilitação ser encarada como uma exigência ética, estamos diante de um conceito ainda em construção mesclando diferentes proposições. Para fins didáticos, a autora identificou no debate da reabilitação psicossocial no Brasil três grandes modelos epistêmicos predominantes: os modelos psicoeducativos, os modelos sociopolíticos ou críticos e os modelos de 
orientação clínica. Nos primeiros, o foco é na aprendizagem de habilidades e manutenção de repertórios de comportamentos pelo sujeito e/ou a mudanças contextuais no modo de funcionamento da dinâmica familiar, visando o restabelecimento de um estado de equilíbrio e adequação entre indivíduo, família e comunidade. Já os modelos sociopolíticos consideram que, para além dos manuais de reabilitação, seria preciso conhecer as realidades locais para determinar as redes de intervenção. Trata-se de uma abordagem inclusiva que tenta romper com a lógica meramente produtiva, apoiando-se, principalmente, na dimensão política e social do processo reabilitador. Os modelos de orientação clínica rompem radicalmente com os modelos psicoeducativos e a proposta de uma intervenção voltada para a remissão de sintomas e comportamentos tomados como "inadequados". Nessa perspectiva, esses se aproximam mais dos modelos sociopolíticos por considerar importante a retomada da vida pública do sujeito dentro do seu campo de possibilidades. A ênfase à dimensão particular, única e irredutível valoriza a singularidade do sujeito e das intervenções, assim como a responsabilização do sujeito pelas respostas que apresenta.

Estamos em um momento de descobertas, de invenção e experimentação, cujas ações serão avaliadas a partir dos usuários envolvidos. Acredito na construção de uma cidadania possível, ampliando a capacidade contratual de cada sujeito para além da sua emancipação meramente política. (Basaglia, 2001) Desinstitucionalizar a própria cidadania é reconhecê-la como um campo aberto e relacional sob uma perspectiva dialógica e participativa com espaço para a diversidade. Portanto, proponho o deslocamento da cidadania alienada para a cidadania ampliada que visa:

uma emancipação pessoal, social e cultural, que permita, dentre outras coisas, o não-enclausuramento de tantas formas de existência banidas do convívio social; que passe a encampar todas as esferas e espaços sociais; que permita um olhar mais complexo que o generalizante olhar do igualitarismo; e busque a convivência tolerante com a diferença. (Alverga \& Dimenstein, 2006, p. 303)

O milagre da "cura" da alienação está na transformação do cotidiano. Se desejamos construir um novo lugar sociopolítico-conceitual-cultural para a loucura, é preciso levar em conta a gestão de uma série de fatores administrativos, financeiros, organizacionais, técnicos, afetivos, subjetivos, articulados à uma reflexão crítica sobre as formas de vida em sociedade. (Alverga \& Dimenstein, 2006) Significa dizer que, 
podemos inaugurar novos devires, não mais a serviço da conservação da alienação, mas a serviço da liberdade e do potencial humano. Por esse motivo, mais importante que dar velocidade para implementação da reforma psiquiátrica, é garantir que estamos caminhando na melhor direção, sem perder de vista o impulso ético do encontro das alteridades. 


\section{DAS FONTES QUE BEBI}

Alverga, A. R., \& Dimenstein, M. (2006, jul/dez). A reforma psiquiátrica e os desafios na desinstitucionalização da loucura . Comunicação, Saúde, Educação, 10(20), pp. 299-316.

Alves, L. (2005). Os direitos humanos na pós-modernidade. São Paulo: Perspectiva.

Amarante, P. (1995). Loucos pela vida: a trajetória da reforma psiquiátrica no Brasil. Rio de Janeiro: Fiocruz.

Amarante, P. (1994). Psiquiatria Social e Reforma Psiquiátrica. Rio de Janeiro: Fiocruz.

Amarante, P. (1995). Loucos pela vida: a trajetória da reforma psiquiátrica no Brasil. Rio de Janeiro: Fiocruz.

Amarante, P. (2013). Saúde mental e atenção psicossocial. Rio de Janeiro: Fiocruz.

Amarante, P., \& Nocam, F. (2012). Saúde Mental e Arte. São Paulo: Zagodoni.

Antúnez, A. E. (2012). Perspectivas fenomenológicas em atendimentos clínicos: humanologia. São Paulo: Tese (Livre-Docência - Departamento de Psicologia Clínica.) - Instituto de Psicologia da Universidade de São Paulo .

Arbex, D. (2013). Holocausto brasileiro. São Paulo: Geração Editorial.

Basaglia, F. (2001). A Instituição negada: relato de um hospital psiquiátrico. Rio de Janeiro: Graal.

Bauman, Z. (2007). Vida Líquida. Rio de Janeiro: Jorge Zahar.

Bergson, H., \& Castilho, G. d. (2007). O riso: ensaio sobre o significado do cômico.

Bezerra Jr, B. (2007). Desafios da reforma psiquiátrica no Brasil. 17(2), pp. 243-250.

Birman, J., \& Costa, J. F. (1994). Organização de instituições para uma psiquiatria comunitária. Em: P. Amarante, Psiquiatria Social e Reforma Psiquiátrica, pp. 41-72. Rio de Janeiro: Fiocruz.

Bizerril Neto, J. (2004, jul/dez). O vínculo etnográfico: intersubjetividade e co-autoria na pesquisa qualitativa. Universitas Ciências as Saúde (2), pp. 153-163.

Brasil, M. d. (2005). Reforma Psiquiátrica e Política de Saúde Mental no Brasil. Conferência Regional de Reforma dos Serviços de Saúde Mental: 15 anos Depois de Caracas. Brasília.

Brasil, M. d. (2004). Residências terapêuticas: o que são, para que servem. Ministério da Saúde, Secretaria de Atenção à Saúde, Departamento de Ações Programáticas Estratégicas, Brasília. 
Butler, J. (2011). Marcos de guerra. Las vidas lloradas. Política y Sociedad. Buenos Aires: Paidós.

Butler, J. (2006). Vida precaria: el poder del duelo y la violencia. Buenos Aires: Paidós.

Campos, É. B., \& Coelho Jr., N. E. (2002, junho). O conceito de alucinação em Merleau-Ponty: aspectos clínicos e psicopatológicos. Rev. Latinoamericana Psicopatologia Fundamental (2), pp.13-27.

Carbonari, P. C. (2007). Sujeito de direitos humanos: questões abertas e em construção. In R. M. Silveira, Educação em direitos humanos: fundamentos teóricometolológicos. João Pessoa: Universitária.

Carvalho, J. M. (2002). Cidadania no Brasil. O longo Caminho. Rio de Janeiro: Civilização Brasileira.

Castro-Gómez, S. (2005). Ciências sociais, violência epistêmica e o problema da "invenção do outro. Em: A colonialidade do saber: eurocentrismo e ciências sociais. Perspectivas latino-americanas, pp. 169-186. Buenos Aires: CLASCO.

Cooper, D. (1974). O que é a Anti-Psiquiatria? Em: Gramática da Vida, pp. 69-81. Lisboa: Editorial Presença.

Costa, D. F., \& Paulon, S. M. (2012, out/dez). Participação Social e protagonismo em saúde mental: a insurgência de um coletivo. Saúde em Debate, 36(95), pp. 572-582.

Costa, V. E., \& Medeiros, M. (2009, abril/junho). O tempo vivido na perspectiva fenomenológica de Eugène Minkowski. Psicologia em Estudo (14), pp. 375-383.

Dalgalarrondo, P. (2009). Psicopatologia e semiologia dos transtornos mentais. Porto Alegre: Artmed.

Debord, G. (1997). A sociedade do espetáculo. Rio de janeiro: Contraponto.

Diniz, D. (2013). A custódia e o tratamento psiquiátrico no Brasil: censo 2011. Brasília: Letras Livres/ UnB.

Ferigato, S. H., Campos, R. T., \& Ballarin, M. L. (2007). O atendimento à crise em sauúde mental: ampliando conceitos. Revista de Psicologia da UNESP, 6(1), pp. 3144.

Ferreira, J. (1995). Corpo e significado: ensaios de antropologia social. Em: L. OF, Semiologia do corpo (pp. 89-104). Porto Alegre: EduFRS.

Foucault, M. (1978). A história da loucura. São Paulo: Perspectiva.

Foucault, M. (1979). Microfísica do Poder. Rio de Janeiro: Graal. 
Freire, P. (1997). Educação" bancária" e educação libertadora. Em M. H. Patto, Introdução à Psicologia Escolar, pp. 61-78.

Goffman, E. (1988). Estigma - notas sobre a manipulação da identidade deteriorada. São Paulo: Perspectiva.

Goffman, E. (1979). Manicômios, prisões e conventos. São Paulo: Perspectiva.

Gonçalves, D., Mari, J. d., Bower, P., Gask, L., Dowrick, C., Toófoli, L. F., et al. (2014). Brazilian multicentre study of common mental disorders in primary care: rates and related social and demographic factors. Caderno de Saúde Pública, 30(3), pp. 623-632.

Guerra, A. M. (2004, jun). Reabilitação psicossocial no campo da reforma psiquiátrica: uma reflexão sobre o controverso conceito e seus possíveis paradigmas. Revista Latinoamericana de Psicopatologia Fundamental , VII (2), pp. 83-96.

Hall, S. (2006). A Identidade Cultural na Pós-Modernidade (11 ed.). (DP\&A, Ed.) Rio de Janeiro.

Japiassu, H. F. (2006). A crise da razão no Ocidente. Revista em Educação Ambiental, (1)1,pp. 27-41.

Lefèvre, F. (1999). A saúde como fato coletivo. Saúde e Sociedade, 8(2), pp. 83-91.

Lefèvre, F., \& Lefèvre, A. M. (2006, jul/dez). O sujeito coletivo que fala. Comunicação, Saúde, Educação, 10 (20), pp. 517-524.

Lefèvre, F., Lefèvre, A. M., \& Marques, M. C. (2009). Discurso do sujeito coletivo, complexidade e auto-organização. Ciência \& Saúde Coletiva, 14 (4), pp. 1193-1204.

Lévy, P. (1966). O que é o virtual? São Paulo: Editora 34.

Lima, E. L. (2007). Do corpo ao espaço: contribuições da obra de Maurice MerleauPonty à análise geográfica. GEOgraphia .

Lipovetsky, G. (2007). A felicidade paradoxal: ensaio sobre a sociedade de hiperconsumo. São Paulo: Companhia das Letras.

Tv Pinel. (2013). Rio de Janeiro, 18 nov. 2013. Disponível em: http://tvpinel2011.blogspot.com.br. Acesso em: 5 out. 2014.

Lowy, M. (1991). Marxismo. Em: Ideologias e ciência social. Elementos para uma análise marxista. São Paulo: Editora Cortez.

Machado, A. L. (2004). Reforma psiquiátrica e mídia: representações sociais na Folha de S. Paulo. Ciência \& Saúde Coletiva, 9 (2), pp. 483-491.

Maciel, S. (1997). Corpo invisível: uma nova leitura na filosofia de Merleau-Ponty. Porto Alegre: EDIPUCRS. 
Martins, F. (1994). O que é pathos? Revista Latino-Americana de Psicopatologia Fundamental, 2 (4), pp. 2-7.

Merleau-Ponty, M. (1996/2009). Le cinéma et la nouvelle psychologie. Paris: Gallimard.

Mesquita, J. F., Novellino, M. S., \& Cavalcanti, M. T. (2010). A Reforma Psiquiátrica no Brasil: Um novo olhar sobre o paradigma da saúde mental. Rio de Janeiro UFRJ, 2010 .

Minkowski, E. (2000). Breves reflexões a respeito do sofrimento aspecto pático da existência. Revista Latinoamericana De Psicopatologia Fundamental, vol. III, pp. 156-164.

Minkowski, E. (1927/2002). La schizophrénie. Éditions Payot.

Miranda, L. L. (2007, jan/jun). Consumo e produção de subjetividades nas tvs comunitárias. Revista do Departamento de Psicologia - UFF, 19 (1), pp. 199-214.

Moreira, A. F., \& Câmara, M. J. (2008). Reflexões sobre currículo e identidade: implicações para a prática pedagógica. In A. F. Candau, Multiculturalismo: diferenças culturais e práticas pedagógicas (pp. 38-66). Petrópolis: Vozes.

Morin, E. (1996). Epistemologia da complexidade. Em: D. F. Schnitman, ovos paradigmas, cultura e subjetividade (pp. 247-286). Porto Alegre: Artes Médicas.

Morin, E. (1999). O Pensar Complexo: Edgar Morin e a crise da modernidade. Rio de Janeiro: Garamond.

Neubern, M. (2001, maio/agosto). As Emoções Como Caminho Para Uma Epistemologia Complexa da Psicologia. Psicologia: Teoria e Pesquisa, 16 (2), pp. 153-164.

Novaes, R. (2006). Culturas jovens: novos mapas do afeto. Rio de Janeiro: Jorge Zahar.

Oliveira, A. G., \& Alessi, N. P. (2005). Cidadania: instrumento e finalidade do processo de trabalho na reforma psiquiátrica. Ciência \& Saúde Coletiva, 10, pp. 191203.

Ortega, F. (2008). O corpo incerto: corporeidade, tecnologias médicas e cultura contemporânea. Rio de Janeiro: Garamond.

Patto, M. H. (2000). A produção do fracasso escolar: histórias de submissão e rebeldia. São Paulo: Casa do Psicólogo.

Peixoto, A. (2014, maio/agosto). Razão, corpo, existência e formação em MerleauPonty: contribuições para a descolonialidade do fazer pedagógico. Revista de Educação Pública , 23 (n. 53/1), pp. 311-324. 
Pereira, M. E. (2004, junho). A perda do contato vital com a realidade na esquizofrenia, segundo Eugène Minkowski. Revista Latinoamericana de Psicopatologia Fundamental, VII, pp. 125-129.

Peruzzo, C. M. (2011). Direito à comunicação comunitária, participação popular e cidadania. São Paulo: Revista ALAIC 3.

Peruzzo, C. M. (2008, ul/dez). Televisão comunitária: mobilização social para democratizar a comunicação no Brasil. Em Questão , 14 (2), pp. 177 - 189,.

Pinsky, C. B., \& Pinsky, J. (2007). História da cidadania. São Paulo: Contexto.

Psicologia, C. F. (2010). Por uma IV Conferência Antimanicomial: contribuições dos usuários. IV Conferência Nacional de Saúde Mental - Intersetorial . Brasília: CFP.

Quijano, A. (2007). Colonialidad del poder y clasificación social. Journal of WorldSystems Research, 6(2), pp. 342-386.

Rotelli, F. (1990). A instituição inventada. In N. MF., Desinstitucionalização (pp. 8999). São Paulo: Hucitec.

Sampiere, R. H., Collado, C. F., \& Lucio, P. B. (2013). Metodologia de Pesquisa. São Paulo: McGraw-Hill.

Santos. (2005). Filosofia e as gentes - um estudo sobre a origem das diferenças. In D. J. Libório, Valores, preconceitos e práticas educativas. São Paulo: Casa do Psicólogo.

Santos, B. d. (1999). A construção multicultural da igualdade e da diferença. Coimbra: CES.

Segato, R. L. (2006, Abril). Antropologia e Direitos Humanos: o papel da ética na expansão dos direitos universais. Mana, 12 .

Soares, I. d. (2004). Comunicação e saúde mental: a democratização dos meios comunicacionais como veículo de reconstrução identitária. Psicologia: ciência e profissão , 24 (4), pp. 12-21.

Spivak, G. C. (2010). Pode o subalterno falar? (1 ed.). (S. R. Almeida, M. P. Feitosa, \& A. Pereira., Trans.) Belo Horizonte: Editora da UFMG.

Szasz, T. (1980). Ideologia e doença mental: ensaios sobre a desumanização psiquiátrica do homem. Rio de Janeiro: Zahar.

Tenório, F. (2002, jan-abr). A reforma psiquiátrica brasileira, da década de 1980 aos dias atuais: história e conceitos. História, Ciências, Saúde, 9, pp. 25-59.

Torre, E. H., \& Amarante, P. (2001). Protagonismo e subjetividade: a construção coletiva no campo da saúde mental. Ciência \& Saúde Coletiva, 6 (1), pp. 73-85. 
Tundis, S. A., \& Costa, N. (2000). Cidadania e loucura: políticas de saúde mental no Brasil. Petrópolis: Vozes.

UNESCO. (2005). Convenção sobre a Proteção e Promoção da Diversidade das Expressões Culturais. Disponível em: http://www.cultura.gov.br/politicas5//asset_publisher/WORBGxCla6bB/content/convencao-sobre-a-protecao-e-promocaoda-diversidade-das-expressoes-culturais/10913. Acesso em: 19 jan. 2015.

Vasconcelos, E. M. (2000). Reinvenção da cidadania, empowerment no campo da saúde mental e estratégia política no movimento dos usuários. In P. Amarante, Ensaios: subjetividade, saúde mental, sociedade (pp. 169-194). Rio de Janeiro: Fiocruz.

Vieira, M. G., \& Furlan, R. (2011, jan/jun). Algumas considerações sobre psicopatologia na filosofia de Merleau-Ponty. Ágora , XIX (1), pp. 129-141.

Vygotski, L. S. (2007). La tragedia de Hamlet: Psicología del arte. Madrid: Fundación Infancia y Aprendizaje.

Zizek, S. (2010). Como Marx inventou o sintoma? Em: S. Zizek, Um mapa da ideologia. Rio de Janeiro: Contraponto. 


\section{ANEXOS \\ ANEXO 1 \\ Termo de Consentimento Livre e Esclarecido}

Você está sendo convidado a participar da pesquisa "Novos caminhos de desinstitucionalização em saúde mental: a experiência da TV SÃ", de responsabilidade da pesquisadora Kéren Moreira de Alcântara, aluna de mestrado da Universidade de Brasília. O objetivo desta pesquisa é analisar as possíveis contribuições do projeto Tv Sã no campo da saúde mental. Assim, gostaria de consultá-lo(a) sobre seu interesse e disponibilidade de cooperar com a pesquisa.

Você receberá todos os esclarecimentos necessários antes, durante e após a finalização da pesquisa. Os dados provenientes de sua participação na entrevista ficarão sob a guarda da pesquisadora responsável pela pesquisa, não haverá divulgação das entrevistas dos participantes por qualquer meio de comunicação, exceto nas atividades vinculadas ao ensino e a pesquisa explicitadas acima. A coleta de dados será realizada por meio de entrevistas focais, ou seja, integrantes e exintegrantes do grupo Tv Sã serão entrevistados grupalmente promovendo um debate aberto e acessível sobre temáticas de interesse comum a todos. É para estes procedimentos que você está sendo convidado a participar.

Espera-se com esta pesquisa instigar reflexões sobre a participação de cada integrante no grupo e promover maior esclarecimento sobre os objetivos do projeto e a suas colaborações no processo social e político da Reforma Psiquiátrica. Além disso, a pesquisa também contribuirá para dar maior visibilidade ao trabalho realizado pelo grupo.

Os riscos dessa pesquisa são inerentes a procedimentos que envolvem depoimentos pessoais. Se alguma questão, temática ou evento produzir qualquer constrangimento ao participante da pesquisa, o procedimento será interrompido e o participante poderá receber acompanhamento psicológico individual, se assim desejar. Sua participação é voluntária e livre de qualquer remuneração ou benefício. Você é livre para recusar-se a participar, retirar seu consentimento ou interromper sua participação a qualquer momento. A recusa em participar não irá acarretar qualquer penalidade ou perda de benefícios.

Se você tiver qualquer dúvida em relação à pesquisa, você pode me contatar através do telefone 619117-6793 ou pelo e-mail keren.m.alcantara@gmail.com. A pesquisadora garante que os resultados do estudo serão devolvidos aos participantes da Tv Sã. Os resultados poderão ser publicados posteriormente na comunidade científica. Este projeto foi revisado e aprovado pelo Comitê de Ética em Pesquisa do Instituto de Ciências Humanas da Universidade de Brasília - CEP/IH. As informações com relação à assinatura do TCLE ou os direitos do sujeito da pesquisa podem ser obtidos através do e-mail do CEP/IH cep_ih@unb.br. Este documento foi elaborado em duas vias, uma ficará com a pesquisadora responsável pela pesquisa e a outra com o senhor(a).

Assinatura do (a) participante

Assinatura da pesquisadora

Brasília, de de 


\section{ANEXO 2 \\ INSTRUMENTO DE COLETA DE DADOS}

Pontos a serem investigados nas entrevistas focais:

- Analisar como são desenvolvidas as atividades pelo grupo;

- Compreender a importância da Tv Sã na vida dos participantes do projeto;

- Investigar os aspectos motivadores na entrada dos participantes neste projeto;

- Investigar os fatores que influenciam a permanência ou a saída dos participantes;

- Analisar como grupo Tv Sã percebe as relações que estabelece com outras instituições (família, serviços de saúde mental, ONGs e universidades). 


\section{ANEXO 3 \\ TRANSCRIÇÃO DA ENTREVISTA FOCAL}

Abreviações

P: pesquisadora
H: Henrique
R: Rodrigo
L: Léo
F: Fabiana
E: Elias
M: Maria

P: Vamos lá, eu vou ter que ficar de olho para ver se está gravando. Eu vou ler o termo, eu sei que o texto é grande...é um convite, vocês estão sendo convidados para participar da minha pesquisa de dissertação "Novos caminhos de desinstitucionalização em saúde mental: a experiência da TV SÃ". Chamei vocês porque cada um teve uma participação importante na Tv Sã. Eu até tinha entrado em contato com vocês antes para ver a possibilidade de filmar para a gente fazer um filme sobre a Tv Sã usando o material que foi gravado aqui. Depois eu me dei conta que, além de não ter nada a ver, se a gente for gravar um vídeo da Tv Sã, o roteiro tem que ser coletivo... A gente até poderia usar as imagens, mas não ficaria a mesma qualidade e também atrapalharia na aprovação do comitê. Então fica melhor gravar a entrevista oral e depois a gente pensa no nosso projeto. Então o que é essa pesquisa? (leitura do TCLE e coleta das assinaturas)

Essa pesquisa não tem um protocolo, não tem várias perguntas pré-definidas. A entrevista é grupal, a gente coloca vários assuntos e cada um vai falando e cada um vai falando o que que pensa. Um dos pontos que eu gostaria de investigar é o que motiva, o que que faz com que as pessoas se interessem pela Tv Sã? Por que participar?

H: Tv globinho, cineminha.

P: Mas você teve alguma participação antes?

H: Tive? Ah sim, na verdade me chamaram para fazer uma ponta, meu interesse foi mesmo no negócio do cinema mesmo, na tv globinho. E tipo...gosto de cinema e tal...

R: É bom conhecer alguns lugares também ne, por exemplo Unb. É ótimo, tem conversação, entretenimento, estar ali no meio do pessoal conversando, explicando algumas coisas, conhecer outros lugares, reunir...Procurar livros sobre isso, ir na biblioteca, conhecer alguma coisa mais profunda, é isso...(risos)

(simultaneamente)

H: E outra cara...

H: E outra assim, que eu acredito muito na cura, na cura (pruuu - barulho com a boca) psíquica. Eu acredito, cara... Em maneiras de encontrar, na verdade não é nem 
somente pela tv sã, na saúde mental, e a tv sã, também é um gatilho para divulgar ou enviar, tipo um veículo para promover esse negócio que eu acredito tanto que é a questão da saúde, aliás, da cura mental mesmo, da cura psíquica através de vários recursos que eles tem hoje, tipo meditação, PNL, plasticidade neural.

P: O que você está chamando de cura?

$\mathrm{H}$ : Cura mesmo, de transtornos mais graves tipo esquizofrênia, esse tipo de coisa que traz debilidade da mente... Então não somente pelo atendimento, mas isso também passa pela questão do atendimento da área da saúde, porque assim, eu acho que eles atendem assim, passa a medicação e tal e não reverte o problema na questão efetiva. Eu acredito em meios que possam reverter por completo, $100 \%$ a questão da saúde mental.

R: (falando algo simultaneamente)

P: Pessoal, eu esqueci de falar, mas para eu conseguir ouvir depois, o ideal é cada um falar por vez, mas é legal ter o formato debate. Rodrigo, eu ouvi que você estava falando alguma coisa...

R: É você conhecer outros lugares, se entreter, conversar sobre esses assuntos, conhecer novos caminhos, buscar outras coisas...

P: O que são esses novos caminhos?

R: Caminhos da liberdade... Afastar um pouco do problema, afastar um pouco da família porque a família também atrapalha um pouco. A família está ali para ajudar e ao mesmo tempo, às vezes, atrapalha. Então, procurar novos caminhos, procurar outras coisas, sair um pouco de casa, sair um pouco do tédio para fazer outras coisas, fazer novos amigos, novas amizades, fazer o que gosta, o que tem vontade.

P: Circular por outros ambientes... isso é o que te motivou a vir para a tv sã?

R: Conhecer a cidade...Foi, do lado da família, do outro lado amigos, conversação, bate-papo, conhecer novos livros, conhecer novas coisas, procurar outros lugares, procurar fazer alguma coisa boa.

P: E para os outros? O que motivou à participação?

L: Para mim, o que me motivou nessa participação foi de botar um sentimento meu para fora, por exemplo, publicar para as pessoas "eu me sinto de tal forma, eu passei por isso". As pessoas acabam se identificando com aquela história e acabam se superando também. E eu vendo aqueles vídeos, eu acabo me inspirando para melhorar também, eu me inspiro na minha própria história. Ou seja, começar na tv sã foi um novo processo na minha vida e no meu tratamento como usuário da saúde.

F: O meu interesse pela Tv Sã... Na verdade eu sempre gostei de trabalhar com imagem, com arte. Eu, na verdade, sempre busquei esses espaços de encontro na minha vida que saíssem um pouco de escola, trabalho e proporcionar...assim, encontrar pessoas para inventar alguma coisa nova, criativa. Eu fazendo psicologia, 
quando eu fiz um trabalho com mulheres que sofriam violência e a gente usou a ferramenta do vídeo para elas expressarem o que elas estavam vivendo, sentindo.... E foi ótimo porque elas saíram de um discurso de violência, de sofrimento e começaram a criar coisas completamente novas, criam um vínculo de amizade, de encontro. Então quando eu fiquei sabendo da tv sã, eu achei muito legal, é mais ou menos a mesma proposta... e o projeto já tinha acabado e eu vim conhecer a tv sã. Eu senti um espaço com a mesma ideia, um espaço de encontro, um espaço de aprendizado, de sair um pouco desses lugares que a sociedade fica colocando a gente, lugares fixos. Não só para quem, por exemplo, pra quem está nesse...

(simultaneamente)

R: As vezes o pessoal acha que é uma coisa e é outra, uma pinga, por exemplo, a cerveja... A pinga e a cerveja é destinado da natureza, as coisas boas da vida vem da natureza. Vem do verde, vem da vida, ne... Um prazer que muitas vezes as pessoas criticam, muitas vezes não sabem...

F: É interessante você falar isso porque assim, eu estou (risos), essa semana. Eu pensei nisso..

(simultaneamente)

H: Ayahuasca também tem verde...tem um negócio de cura com isso aí.

F: É pois é (risos). Olha só, você vai ter que cortar um monte de coisa dessa entrevista, mas só pra puxar esse papo da pinga natural e da ayahuasca, por exemplo, eu estou com um recém-nascido da minha irmã e quando ele acorda, ele acorda berrando, mas não é chorando não. Solta uns gritinhos, se espreguiça. Isso aqui é teatro, é canto, é tanta coisa. O bebê, a criança, trabalha tanto o corpo e a voz e a gente vai ficando rígido, rígido, rígido e vai perdendo essa espontaneidade. Igual você falou o lance da cana, da raiz... Então a gente vai saindo desse contato com as coisas mais naturais mesmo, a gente sente falta disso. Aí eu acho que esses trabalhos com coisas criativas puxam uma naturalidade até do corpo, de sair um pouco dessas estruturas rígidas. Eu entrei na tv sã não é só porque, enquanto psicóloga, eu acho um trabalho interessante. Pra mim eu acho interessante, de não entrar numa rigidez mental, profissional.

P: E você, Elias. Membro fundador né?

E: Não.

F: Isso deixa ele constrangido, eu acho que isso que deixa ele preocupado com a fala dele.

E: Essa história de membro fundador não cola, não cola!

P: Você está desde o início da tv sã...

F: Oxi, na minha entrevista você disse "Eu sou o presidente, eu sou o grande rei". Brincadeira.

(todos riram) 


\section{E: (risos) Deixe de conversa!}

$\mathrm{H}: \mathrm{O}$ mestre dos magos!

P: O que fez o Elias participar da Tv sã?

E: Bom, o que me fez participar desse núcleo de comunicação foi... O que vemos sempre é discórdias e só colocação de coisas ruins dentro dessa área da saúde, ne? As pessoas não olham como um ser humano a pessoa da saúde mental. Mas, ao meu olhar, o que falta mesmo e que motiva alguém a querer chegar a esse ponto é exatamente procurar fazer com que direitos possam chegar a determinadas pessoas. $\mathrm{O}$ principal ponto que a tv sã joga é exatamente o fato de que direitos precisam ser postos a essa pessoa como um ser humano, que, como ser humano obtenha esse direito de vida.

No princípio eu apenas fui conhecer o que era a tv sã e, com o tempo, eu passei a frequentar, a entender melhor e ver que o conhecimento de determinadas áreas focava todo em direitos humanos. Atualmente a gente vê até no debate com relação à política do governo em querer fazer de jovens pessoas que, no futuro, possam se tornar escravos da droga e do álcool que é o principal problema de nossa sociedade, ne?

Mas nós queremos que essas pessoas sejam tratadas com humanização e, para tratálas assim, é necessário um trabalho diferenciado para essa pessoa e não só pensar no básico para viver, sem ter a própria educação que é o futuro de tudo que nós precisamos.

E com o tempo que passei na tv sã fui cada vez mais adquirindo conhecimentos e fazendo que pessoas até se sentissem chateadas um pouco a minha presença, ne? Tem uma menina que ela pensa que eu trabalho em órgãos do governo. Ela fala comigo como se eu fosse uma pessoa que tivesse... esses dias ela...

R: condições. (risos)

E: Exato, ela pensa que eu tenho condições financeiras.

H: Mas é pecado?

\section{R: Pecado capital (risos)}

E: Não, não é um pecado, mas ela me trata como se... tem a Juliana Pacheco, ne? Ela é uma profissional de renome na saúde mental, quando ela sai pra qualquer local que seja assim de uma coisa mais abrangente, ela já acha que eu estou próximo dessa pessoa. Como se eu tivesse aquele conhecimento de estar próximo de uma profissional dessa que vai estar em um debate de saúde mental.... Ela vê que eu me envolvo nessa área e pensa que eu estou envolvido em todos os aspectos da saúde mental e qualquer reunião que tenha, de mínima importância ou que seja de grande proporção na saúde mental, eu vou ter que estar envolvido. Aí eu tive que explicar para ela que eu não fico envolvido o tempo nas reuniões que a Juliana Pacheco se encontra porque nem tudo que ela faz é o que eu faço. Porque ela faz na maioria das vezes como profissional, e eu não. Eu faço exatamente para poder lutar pela causa. É o que muitas vezes eles não conseguem entender, eles pensam que eu tenho um profissionalismo ao ponto de saber as coisas, de me envolver como um profissional da mesma área. 
F: Mas eu acho que isso também é válido. Como você realmente já adquiriu bastante conhecimento, você saiu da posição de que é colocado como aquele que precisa de ajuda para uma pessoa que está ajudando e está transmitindo conhecimento. E aí quando uma pessoa te reconhece como um profissional, é ótimo. Não tem problema não.

H: Aí você tem nome, você tem voz para colocar...

F: Mas é engraçado.

E: Quando a pessoa não se deixa conhecer (os direitos), ela acaba se escondendo pra vida. É uma pessoa que não procura a própria vida. Isso é ruim pra ela e pra todas as pessoas que pensam da mesma forma como ela. Ela se acha incapaz de ter conhecimento.

(simultaneamente)

R: Atrapalha, ne? É só ela, só ela, e os outros nada.

P: Vocês levantaram vários pontos: sobre a questão de circular por outros espaços, tornar pública a história e a outra questão é conhecer os direitos, ne? Por que é importante circular e dar visibilidade?

R: Vai aumentando, vai proliferando, vai aumentando, é uma bola de neve, é uma bola de neve.

P: O que vai aumentando?

R: (risos) As coisas vão aumentando, vai fluindo, vai tudo dando certo, vai tudo entrando nos conformes, vai tudo se ajeitando. Às vezes pode certo, às vezes pode dar errado, às vezes pode proliferar, às vezes pode atrapalhar. Às vezes uma coisa é diferente, uma coisa é outra, uma coisa pode, uma coisa não pode...ne?

H: É bom que você aprende a ver pontos de vistas dos outros, sabe? Aprende outros problemas, outros transtornos, outras formas de lidar. Por exemplo, você não sabe lidar com transtorno bipolar, eu sou bipolar, mas assim... Tem situações que eu encontrei um aperto assim, e aí você vê pessoas que tem aquele transtorno e passam por aquilo facilmente, tem uma outra forma de lidar com o mesmo problema que você tem.

P: Trocar experiências semelhantes?

H: Aham. E fora que você aprende que há saídas, como buscar os recursos mais fundamentais para amenizar aquela situação, aquele problema.

P: E como circular essas experiências na sociedade?

E: Um dos lugares que eu mesmo citei é a mídia. O maior problema nosso é a aceitação. O que acontece com a mídia hoje em dia? A mídia joga pra você como se você fosse obrigado a aceitar tudo o que ela está mostrando. O principal problema que 
ela está mostrando atualmente é exatamente com relação ao adolescente. Eu muitas vezes nem entro na casa da minha vizinha pra não entrar em confronto porque ela só assiste esses jornais que falam com muita acusação. Eles acusam demais o jovem como se ele fosse o problema da sociedade. Esses jornais da Record e do canal 6 só falam que o jovem é problema, mas quando a gente vai ver no correto, eles se esquecem que a educação não existe, o professor é esquecido, a melhoria para a família poder ter base e vida não existe, os direitos humanos não aparece para ajudar a pessoa a vencer esse problema. A principal vontade deles é que essa pessoa vá parar na cadeia, porque lá é o melhor lugar para ela ser reeducada. Como é que eu vou reeducar uma pessoa se eu não dou para ela uma chance de vida?

Para a menina que vem pra cá, a Helena, eu tive que falar com ela pelo whatsapp... eu coloquei esse ponto em uma colocação que a Kéren tinha salvado (no facebook) uma fala de uma determinada pessoa que fala sobre os pontos que nós devemos rejeitar sobre a redução da maioridade penal. Aí eu acrescentei o que não ajuda o jovem. Ela pegou e condenou, me mandou um panfleto que aquilo ali não ajudava, que era errado. Eu fui obrigado a mostrar pra ela por experiência própria: eu tive que pegar a causa do meu sobrinho em que ele estava numa casa que só tinha gente maior de idade mexendo com droga e eu percebi que ele tinha entrado no local. Eu cheguei e chamei ele pra não ficar no local e chamei pra ir pra casa. Só aí o que aconteceu, a família ficou contra mim e eu não podia ajudá-lo. Hoje em dia ele se transformou em uma pessoa como um vendedor de droga, mas não foi por minha causa, eu tentei ajudar. A família se tivesse tentado ajudar não teria se transformado nessa pessoa e estaria como uma pessoa com uma melhor aparência hoje. Mas, por não ter ajuda, acabou se "bandeando" pro lado errado.

P: Que relações você consegue ver entre essa medida punitiva de isolar ou prender o jovem pra resolver a situação e a questão da saúde mental?

E: Bom, o que a gente vê de semelhança é que eles querem afastar da sociedade a pessoa como se ela não tivesse... (simultaneamente R: Problema com família) Não tivessem que trazer exatamente pra ele a educação que ele precisa, que é o necessário para ele não se tornar essa pessoa, deixar de ser essa pessoa errada que ele é. Isso eles não procuram trazer para essa criança, a educação.

\section{P: Por que a educação é importante?}

E: Porque se ele tivesse a educação desde o princípio, com certeza, no futuro dele, não se tornaria exatamente a pessoa que comete atos infracionais. A educação é uma base para a sociedade. (simultaneamente L: educação e a cultura, ne?) A educação em si, ela já é o ponto base que te leva para entrar na cultura, porque quando você entra na cultura você já tem a educação em si. Mas para você chegar lá, você precisa do básico, e o básico está na educação e não na cultura. Ela é base para você não ter a necessidade de prendê-lo, de trancafiá-lo porque quando você não dá educação, no futuro vai se envolver com pessoas do tráfico de drogas, vai começar a vender drogas, vai pegar em arma, se achar auto suficiente na sociedade e vai até querer matar pessoas, isso é o que acontece atualmente. Mas se nós não damos chance pra ele ter base, como é que nós vamos conseguir culpá-lo de seus próprios erros? Com a sociedade atualmente faz, ela joga a culpa no jovem pelo seu ato infracional, mas não dá a ele a chance de viver uma vida digna de ter uma educação, que é o próprio Estado que deixa sem ter como essa pessoa ter. 
P: Vou passar pro Leo que falou sobre a cultura também.

L: Eu tenho muitas especializações pra área de cultura, não especializações extensas, essas básicas. Já trabalhei muito nessa área de cultura.

P: As nossas escolas também podem ser punitivas? Essa questão da cultura amplia...

(simultaneamente)

E: Não, eu não falo que você tenha que fazer punição. É que nem o que aconteceu hoje numa reportagem sobre Águas Claras. A escola está querendo punir os professores por determinado ato que eles cometeram dentro da escola e afastaram esses professores porque eles são muito punitivos com os alunos. Tem salas que são reservadas para alunos que eles dizem ser maus alunos. Isso já teve no colégio que eu estudei. Se eu bagunçasse, eu ia pra uma determinada sala diferente, eu não ficava naquela sala.

F: Deu pra entender a questão da educação e aí a gente cortou....O Elias colocou que a educação é uma coisa básica, e é mesmo, mas o Léo colocou que considera a cultura como algo importante, só pra falar da sua experiência.

L: Nessa parte da cultura eu só queria citar mesmo... Essa questão dos usuários de drogas, que ou eles estão nas cadeias ou eles estão nos hospitais psiquiátricos. $\mathrm{Na}$ minha última internação mesmo eu percebi que tinham muitas pessoas usavam drogas, acho que $99 \%$ das pessoas que estavam lá eram usuárias de drogas. E assim, por ser uma instituição pública eu acho que não deveria ter tantas pessoas usuárias de drogas lá dentro do local (HSVP). Eu já vi seguranças lá que proibiam a entrada de alimentos, mas os mesmos seguranças deixavam entrar drogas lá dentro. Eu até achava estranho, não pode entrar comida, mas pode entrar droga? Não faz sentido.

(simultaneamente no final)

R: A droga por um lado faz mal, por outro lado faz bem.

F: E a questão da cultura?

L: Sobre a questão da cultura eu acho essencial porque... a educação, é lógico é fundamental, mas se atrela ela junto com a cultura, se tiver, por exemplo, oficina de artes junto com as escolas, oficinas de vídeo, de informática, de música, essas coisas, desenvolvem talentos nas crianças, nos adolescentes. Eles vão querer se profissionalizar em outras áreas, nas áreas artísticas e nas tradicionais também administração, medicina, outras áreas. Acaba abrindo um leque maior pras pessoas se profissionalizarem.

F: Interessante que a maneira que o Léo colocou, complementa o que você (Elias) estava falando. Como a educação é muito normativa, punitiva, quando ele fala cultura já é uma mudança na própria educação. Abrir espaços nos espaços educativos de uma educação mais aberta mesmo pra essas outras áreas. 
H: O Elias estava falando um negócio aqui, que eu pensei agora um esquema diferente, cara. Porque assim, você baseou a criminalidade do seu sobrinho pela de educação que ele recebeu ou que ele não foi atrás... mais ou menos assim?

E: Não é isso, o que aconteceu com meu sobrinho foi o seguinte: Ele queria se envolver com pessoas que só mexiam com coisas erradas.

H: Sim, por que não tinha educação?

E: Porque ele se achava uma pessoa que precisava estar com pessoas diferentes. Primeiro, porque ele era sempre discriminado pela altura, uma das coisas que ele vê nele. Ele não cresceu direito e as pessoas, por causa do tamanho, colocam apelidos nele. Ele quer mostrar que mesmo sem tamanho ele pode fazer as mesmas coisas que eles fazem. Aí pronto, ele quer fazer exatamente na área da bandidagem, ele quer mostrar pra essas pessoas o que ele pode fazer lá no meio deles.

H: Mas se ele tivesse educação, você acha que....

E: Ele teria uma chance de evitar isso.

H: Porque assim, o que mais você vê é muita gente instruída cometendo crimes. A politicagem é muito criminosa. Só a falta, essa abstinência de recursos pra saúde mental é um grande crime e vem de pessoas muito instruídas, que tiveram educação, tiveram recurso, cultura, tudo que é necessário pra construção de um ser humano. No entanto, se abstém de muitas benfeitorias que poderia estar fazendo. Isso já é um grande crime que vem de pessoas instruídas. Ou seja, educação de um lado, dos que tem o poder, não serve de nada pra quem está lá embaixo, quem não teve educação, sabe? Não tem essa interação, não tem essa ligação, não favorece em nada nesse negócio de saúde mental.

E: Eu vou colocar a mesma coisa que eu coloquei pra Helena. Hoje em dia eles estão brigando pra fazer com que a redução da maioridade penal venha a ser de 16 anos, só que nós vemos que até hoje não houve melhoria na educação, nem em nenhuma área, fazendo dela capaz de instruir essas crianças e fazer com que elas não sigam esse caminho do qual você está querendo chegar.

P: Nós podemos criar um outro debate só para discutir a redução. Acho que tem muito pano pra manga... Mas isso me faz lembrar uma questão: que embora as pessoas tenham condições diferentes, elas estão sujeitas as mesmas coisas. Rica ou pobre, eu posso surtar; rica ou pobre, eu posso ser ética; rica ou pobre eu posso me corromper. Existem coisas que são independentes...

F: Com a educação também: com educação ou sem educação tem gente criminosa.

P: Sim. E na saúde mental, existem encaminhamentos diferentes para classes diferentes?

L: Na novela que passava na globo, não estou lembrado da novela, tinha até o Bruno Gagliasso que interpretava uma pessoa que tinha esquizofrenia. Eu quando eu descobri meu CID, ele passou bem próximo de esquizofrenia, era transtorno bipolar com sintomas psicóticos. De vez em quando torna-se o hipomaníaco, de vez em 
quando volta com sintomas psicóticos de novo, são situações bem parecidas com a esquizofrenia. Na novela ele estava numa clínica de luxo, tinha música e tal. Mas quando eu me vi pela primeira vez no hospital psiquiátrico internado, não tinha nada a ver. Era violência que tinha, uso de drogas... Um monte de coisas só tinha na novela, talvez tenha em uma clínica onde ricos estejam, não sei se tem, mas... O louco rico tem possibilidade de cura bem mais rápido porque a família tem condições de pagar um tratamento de 5 estrelas pra ele. O louco pobre já tem uma condição precária: falta médico, falta remédio pra ele, ele não pode comprar todos os remédios.

E: Bom, o problema de classe social está desde quando surgiu o Brasil, ne? Nos vemos que as pessoas que vieram a construir a Bahia eram de uma classe miserável, sofriam muito e, se nós prestarmos atenção no tipo de coisas que foram construídas, só tem a ver com essas pessoas. Foram construídos barracões que são exatamente o formato que essas pessoas viviam... Hoje eu dia eles colocaram como símbolo da humanidade porque agora eles querem mostrar essas pessoas, porque agora elas já morreram. É como se essas pessoas, depois de mortas, elas tem algum valor. Quando vivas, viviam levando chicoteadas, levando porradas e tendo que trabalhar forçado. Onde é que está o amor dentro da nossa sociedade quando chega a esse ponto? Você vê que ela não foi uma pessoa humanizada, que teve respeito por ninguém, desde o princípio no Brasil ne? Nós vemos isso no Brasil, no Rio de Janeiro....

F: Mas você está respondendo a pergunta do louco pobre e do louco rico?

E: Mas é exatamente isso. (F: Tá bom.) É porque a classe social do... eram só pessoas que eram pobres que tinham vindo da África pra poder trabalhar como escravos, elas não tinham vindo pra poder ser uma sociedade.

P: Você acha que isso teve influência na forma que a gente entende cidadania hoje?

E: Tem!!! Como ele vê a cidadania? A cidadania é dada pra pessoas de nível social que vieram de descendência de determinada áreas do.... (R: Panamá, Haiti, Colômbia)... de Portugal e vários outros países de renome para o Brasil. Mas as pessoas que vieram e tem a descendência africana aqui, não é uma pessoa bem vista, é mal olhada pela própria sociedade. A sociedade olha você com um olhar diferenciado na sua maioria, não adianta que isso acontece... As pessoas passam por você e não te olham como se fosse um ser humano, elas te olham como se você fosse um ninguém, ne?

P: Então você diz que tem um antecedente histórico...

E: Que faz com que isso acontece e muito!

H: Então, eu achei até bom o Elias falar esse negócio sobre o Brasil... A porrada come feio e tal. Como é mesmo? Esqueci a pergunta.

A gente está num país muito corrupto e tal. E aí, cara, além da classe dominante não favorecer a área de saúde mental como deveria favorecer, então a gente depende de ONGs assim, com pequenas ideias, exercendo essa circularidade, pra tentar mudar mesmo a questão da identidade, do pensamento, quanto a questão da saúde mental, do potencial daqueles que tem algum transtorno, alguma debilidade cerebral, neural. E não depender, ne... A gente sabe que esse negócio da educação não vai mudar da noite 
pro dia, não vai acontecer de súbito, de repente cai do céu. E aí a gente pega atividades assim como a tv sã, a Inverso ou os CAPS ou uma intervenção urbana; e a gente vai moldando, lapidando essa questão da percepção geral da sociedade contra esse negócio da discriminação que vem desde lá dos portugueses, e que varia desde a questão da cor da pele e evoluiu pra questão da saúde mental, evoluiu pra questão da loucura, do delírio, da incapacidade e tudo mais. E claro que a gente nunca vai bater de testa com essa galera que está ali no top, na classe dominante. Mas investir em pequenas ideias, sabe? Pequenas intervenções, ações, tv sã, uma ong aqui, uma ong ali, isso vai mesmo divulgando o trabalho e aprimorando a questão da influência... Aqui, aqui e ali, sem bater de testa, nem não precisa.

P: Por que a gente não consegue bater de frente?

H: O sistema já está formado. Pra mim assim, nunca mudou. Já teve Color, Lula, não sei o que. O sistema já está formado. Até pode ser criada uma lei que possa reverter esse quadro da saúde mental, reverter o atendimento psiquiátrico dos centros de saúde, só que assim.... Não é que a gente não deva bater de frente com eles, mas a gente não deve depender como se a força viesse deles, daqueles que estão lá cima dominando no legislativo, no executivo, no judiciário. Como se a força viesse deles pra trazer essas mudanças que na verdade são muito radicais. Porque poder pra fazer eles sempre tem, por que eles não fizeram?

L: Se em pouco mais de 500 anos o Brasil não mudou muita coisa que deveria ter mudado, não vai mudar da noite pro dia também, ne?

R: (risos) To brincando.

P: O que você falou, Rodrigo?

R: Não, é conhecer novas pessoas, conhecer novos amigos, novos povos, novos lugares. Se entreter, aproveitar um pouco da vida de outra forma, é bom de vez em quando.

(chegada da Maria, mãe de Rodrigo)* participante com nome fictício.

P: Só para contextualizar para Maria: (apresentação do TCLE, breve resumo dos pontos já discutidos pelo grupo). Perguntei a cada um, "por que entrar na tv sã?", e você?

M: Eu não queria ser entrevistada, primeiro por que eu não sei quase nada da tv sã pra poder estra falando.

F: Você sabe igual.

* inicialmente, Maria pediu para não participar, pois dizia saber muito pouco sobre a Tv Sã. Em seguida, disse que antes de participar, queria saber sobre a viagem realizada pelos profissionais da Inverso à Itália. A participante informou que precisava receber um feedback após o retorno, pois aqueles que ficam no país esperam alguma novidade. 
Também questionou sobre os estagiários que frequentam o espaço que, segundo ela, nunca tinham nenhuma informação sobre os acontecimentos da ONG. O pedido de esclarecimento sobre o funcionamento da Inverso nesses pontos específicos não tem relevância para essa pesquisa. Entretanto, o assunto fomentou uma discussão à respeito das cooperativas.

M: Tanta coisa boa que deve ter acontecido por lá...Porque assim ficou muito...Foram, ficaram lá muito tempo passeando e aí ficou aquela expectativa "como é que é lá?". Pra vocês que estão estudando não tem muita novidade que apesar de você não ter ido lá você sabe tudo. Mas pra nós que não sabemos nada sobre saúde mental de lá, que é modelo...Assim, porque quem tá estudando... Eu não estou estudando nada desse modelo de lá que veio pra cá.

F: Sabe qual é a novidade? Parece que eles querem trazer a ideia de cooperativa de trabalho, em vez de oficina (e a Eva me falou) é partir para cooperativas.

M: Eu fico vendo "Elias, tem vindo? Elias não tem aparecido mais". Não está vindo, eu digo assim, tem qualquer coisa acontecendo. Eu pergunto "Rodrigo, Elias veio hoje? Elias veio hoje?". Eu fico monitorando (risos). Sabe quais são os dias que ele vem aqui, eu te digo, sem eu saber, mas vamos ver se eu acerto: você vem no dia de terça-feira, que é o dia que a dona Eva está aqui.

E: Não. Eu só venho na segunda e na maioria das vezes na sexta.

M: E o resto da semana, não está mais aqui. Gente, o que é que o Elias não está mais frequentando.

E: Não, eles (os frequentadores) já tiveram essa pergunta.

F: Mas olha só, a Eva, outra coisa que ela colocou. Ela adoraria que as pessoas não precisassem da Inverso, que elas se emancipem, que elas ocupem os lugares. Então aqui é um lugar de passagem, de transição, não um lugar pra ficar. A ideia é essa, as pessoas tem que entender. Não é que é ruim isso.

(simultaneamente)

M: Eu já percebi isso. Eu estou falando pra Rodrigo e ele faz o inverso. (risos) Segunda, quarta, quinta e sexta.

F: Mas se ele não tiver nada melhor pra fazer, ótimo.

E: Deixa eu falar aqui, eu já prestei atenção no que aconteceu na reunião lá no Buriti e num colégio que tem lá próximo. O que acontece, lá foi a maioria do pessoal da saúde mental pra poder lutar pelo DF. Nós jogamos muitas coisas que estão em falta aqui. Uma das coisas que a Maiara (Caps Taguatinga) me pediu foi o seguinte: que eu lutasse por essa causa que a gente está comentando aqui. Por causas em que envolva cooperativas porque é pra fazer com que o governo crie projetos dentro do DF para que essas pessoas que não tem emprego, elas possam alcançar alguma renda aqui. Se ela não tem renda e não estão querendo dar pra ela, tendo uma cooperativa, poderá ter sua própria renda e não depender do salário que o Estado fica sonegando o tempo todo. 
H: O negócio é assim Elliot (brincadeira com o nome Elias): E se não criar, você vai bater de testa com o governo pra instigar ele a criar, ne? E se não criar? A Dilma quebrou o Brasil, cara. Ferrou cara.

E: No DF há um verba que tem que vir. Não tem esse negócio de Dilma dizer que não vai mandar porque a verba do DF é algo que a União já tem aprovado. Isso não sou eu que falo, é a Constituição que fala.

H: Olha, a própria Constituição que fala tanta coisa de você que deveria fazer em benefício seu, não faz. Você vai continuar confiando nessa Constituição.

P: Então lutar pelas garantias no papel, na lei, não é suficiente?

H: De jeito nenhum. Se fosse suficiente já teria resolvido muita coisa. Isso aqui já (risos), já estaríamos no Vaticano, saudando lá o Papa.

L: Ainda sobre essa questão do cooperativismo, do profissionalismo.... Eu lembrei das oficinas de edição, por exemplo. É uma coisa que a gente pode, por exemplo, oferecer certificado, não sei se vai ter essa possibilidade aqui. Isso é para as pessoas se profissionalizarem lá fora, pois ganha uma experiência aqui e usa lá fora. Eu já tive amigos que fizeram cursos, mini cursos, 4 ou 5 aulas, receberam certificado e avançaram pra outros cursos melhores. Gostaram dos cursos, foram pra outros cursos mais avançados e hoje já são profissionais na área. Um amigo meu, ele é fotógrafo e começou fazendo curso de fotografia básica, de edição básica e hoje virou fotógrafo já, pela própria ONG que ele estudou os cursos e ganhou dinheiro por fora também.

\section{M: A ONG ofereceu os cursos e dá o certificado?}

L: É. Aí ele é fotógrafo da ONG e trabalha pra fora também.

P: A reinserção sempre está vinculada à trabalho remunerado?

L: Não necessariamente. Mas por exemplo, você vai no hospital público pegar remédio, se não tem, você vai ter que comprar, você vai ter que ter o dinheiro. Todo o remédio que eu tenho que comprar não tem no hospital público, não tem de graça. Tem mês que eu gasto 600 a 800 reais com os remédios, às vezes eu recebo bem menos do que isso pelo INSS, eu vou ter que trabalhar.

E: Quem tem a renda de um melhor nível social não vai estar dependente da área pública como nós de classe mais indigna, como diz o povo. Nós dependemos da falta de médico, seja em qualquer área, nós dependemos dos problemas de excesso de gente num hospital público, nós vivemos a falta de médico em toda a área do governo, e isso não tem como negar. Isso já é um fato real que as pessoas convivem o tempo inteiro.

M: O governo não supre as necessidades básicas.

E: Não supre. Com isso, quem tem uma classe social a mais, ele só vai ter que tirar do que ele ganha pra poder pagar e ter um melhor atendimento. Isso não tem como a 
pessoa de um nível social abaixo pagar, porque ele não tem condições nem de ir ao local para ter o atendimento, como é que ele vai pagar?

M: Se ele aprender, se ele for treinado, dependendo da deficiência... Na APAE, eu já frequentei a APAE: "quem gostaria de trabalhar com flores para casamento?". Então aqueles que tem habilidade, pra isso você tem que tentar. Um recorta, outro vem faz assim, outro isso. No fim das contas chega a flor linda e maravilhosa. Eles tem uma cooperativa pra todo mundo conhecer. Cada um faz uma parte, não é que ele vai fazer tudo. Ele nessa cooperativa vai ganhar o dinheiro dele.

E: Ein, dona Maria, vou mudar um pouco o foco pra colocar exatamente na saúde mental, ne? No HSVP há muito atendimento, nem todas as pessoas que são atendidas lá fazem parte de oficina, nem no HSVP, nem em local algum. Pra eles, aquela pessoa é só alguém que vai pegar uma receita e voltar pra sua casa. Se eles disserem que vão dar oficina pra todo mundo, eles vão estar sobrecarregando, dizendo eles, o próprio SUS. É o dizer deles. Mas e aí? E essas pessoas que são atendidas não só no HSVP, como em todos os lugares aqui no Brasil. Elas tem condições de estar fazendo esse tipo de trabalho que a senhora mostrou, que esses meninos fazem. Existem outros a parte e não há atendimento nesses outro lugares. Isso é que nós queremos que essas pessoas tenham, no entanto, nós não vemos chegar para essas pessoas esse tipo de atendimento.

P: E na tv sã? Aqui ninguém recebe nada... O que faz as pessoas ficarem aqui?

L: Na minha última internação, acho que minha última internação foi muito marcante porque eu falo muito dela, ne? Foi o período que eu fiquei mais tempo também... Teve um dia que teve um pessoal pedindo fósforo para acender cigarro e o médico pegou o fósforo, riscou e jogou na caixinha. Queimou as duas caixinhas de fósforo que ele tinha e começou a falar: Vamos lá pra fora, vamos trabalhar. Só que às vezes a pessoa não tem experiência nenhuma, toma remédio psiquiátrico. Quem toma remédio quase sempre é discriminado pelas empresas: "ah toma remédio psiquiátrico, vai atirar pedra nos outros funcionários da empresa". Nem sempre é isso. Eu tomo remédio pra cuidar da minha saúde. O próprio entrevistador meu pode remédio pra cuidar de algum outro problema que ele tenha também. Todo mundo tem algum problema na vida, ele pode até não tomar remédio, mas tem algum problema também. Então assim, a tv sã é um trabalho voluntário. Estou pretendendo chegar a um trabalho voluntário aqui futuramente com as oficinas de edição, é um trabalho gratificante, uma experiência que eu vou estar ganhando e lá fora poder me profissionalizar na área. Eu sempre quis dar aula um dia, quem sabe eu possa dar a partir da experiência daqui. Então, a tv sã, com falaram aqui, é um lugar de passagem, ninguém fica pra sempre. No CAPS eu também morria de medo de sair do CAPS, hoje eu já rezo pra sair de lá (risos).

F: Mas é um lugar bom também, ne?

L: É um lugar bom, mas assim, eu pretendo voltar lá um dia pra trabalhar lá, oferecer algum trabalho voluntário, prestar algum serviço, dar um retorno pra eles também. Porque eu estou na sociedade, posso estar sem recursos financeiros nenhum, mas eu sou um cidadão igual todos. 
M: A tv sã, pelo pouco que eu sei, precisava de, não sei se é estímulo, o que é, porque as pessoas não podem ficar o tempo todo ali, um grupo só. Claro que tem que ter aqueles que são, não sei como é distribuído, se tem diretor, coordenador, mas as outras pessoas que passam pra ajudar, elas não dão conta de ficar, vamos dizer assim, 1 ano, 2 anos, 3 anos. Eu não sei como é essa estrutura, mas assim: "você tem um compromisso de ficar como voluntária?". Por exemplo, as pessoas que vem na Inverso pra fazer um estágio, eles tem um compromisso aqui. Ou faz direitinho durante quantos meses e vai embora. E aí na tv sã seria a mesma coisa gente, um compromisso, mas não verbal, por escrito, de pessoas de diversas áreas pra dar a sua contribuição, mas estar vinculado ao compromisso que irão ficar, vamos dizer, 6 meses. Depois entrariam outras pessoas. Talvez seja por isso que não ficam essas pessoas. Foram embora com seus problemas e tudo, acabaram saindo, não que não gostassem, mas é porque não tinham condições de assumir o tempo todo. São poucos que podem. Por que a Inverso sobrevive? Pelo pouco que eu não sei de nada, mas pelo pouco que eu sei, porque consegue estagiários. Eles vêm, fazem um contrato, sei lá, ficam aqui até tal dia. Acabou, tem uns que nem voltam mais, somem. Só vieram aqui pra cumprir aquela carga horária.

F: É um aprendizado, é um espaço de aprendizado. Não tem problema ir embora. Não é falta de amor ou de interesse. A proposta da tv sã é ser aberta mesmo.

M: Mas aí, e pra ela (tv sã) funcionar?

F: Essa questão de estágio eu não acho interessante. Inclusive, pela proposta da tv sã, tem que ser mais natural. Teve a oficina que a tv pinel tv e aí as pessoas participaram porque queriam também.

H: No fim das contas, não vou receber nada daqui, nem pretenderei mesmo. Acredito piamente na questão da cura psíquica... Não totalmente na cura, mas em uma grande melhora, em um grande benefício por diversos recursos. É isso.

(conversando com o Léo)

Eu já fui curado algumas vezes, eu voltei pro meu estado de calamidade porque eu fiz cagada comigo mesmo, eu já abandonei remédio, largar e nunca mais tomar. Eu não carecia mais de substância, uma experiência assim de sabotagem...

E: O que acontece com a questão do estágio na Tv Sã. Seu princípio foi exatamente esse ponto, foi criada com o propósito de alunos participarem como pessoas voluntárias na tv sã e seguirem o trabalho que tinham iniciado. Mas quando foi passando o tempo, parece que pra eles (estagiários) era algo banal estar na tv sã. Tanto eu como a Andressa (ex-participante), vemos vários problemas porque eles não queriam estar na tv sã. E nós não tínhamos esse negócio de ir atrás deles, se eles quisessem vir, vinham. Como eles não estavam querendo, o que aconteceu? Nós pensamos em sair do próprio UniCEUB e resolvemos vir para a Inverso, onde nós queríamos ter o trabalho com uma melhor qualidade para a Tv Sã, porque ela está próxima exatamente da área que ela estava lutando. Esse é o propósito nosso, lutar por causas e trazer pra eles a causa e fazer eles participarem. Com isso, apareceram alguns estagiários, só que eles só queriam saber a história da tv sã, não queriam participar. Eles me fizeram deixar de participar de vídeos com a Juliana Pacheco lá no Paranoá porque eles queriam estar aqui só batendo papo. Isso me deixava um pouco triste porque eles não queriam ir comigo, mas também não queriam deixar que eu fosse. Foi 
passando o tempo, eu continuei não gostando daquilo e eles perceberam (simultaneamente R: risos) que aquilo não estava sendo muito agradável e deixaram a tv sã. Aí foi quando a própria Fabi apareceu, ne? Quando a Fabi apareceu aí começou a avançar.

M: Quando Kéren e Fabi saírem, como fica?

E: É isso que a gente tenta explicar. A tv sã é coletiva, não sou eu, não é a.... Elas são participantes, eu também sou participante. No entanto, eu não sou o centro.

M: Mas você sozinho não vai conseguir...?

E: Mas aí é que está! Outra pessoa continua.

M: Não é fácil.

P: Assim como no estágio do CAPS ou qualquer estágio, quando você entra em um espaço novo, você estabelece vínculos com as pessoas e pode chegar um momento em que você tem que se desfazer, por vários motivos, por uma questão financeira, pessoal. Isso pode ser passageiro. Ainda que alguém saia, a ideia continua.

E: Um dos pontos que eu vou mostrar pra vocês: esses dias eu estou indo fazer curso pra poder, ano que vem, prestar vestibular. No entanto, quando eu prestar vestibular, se eu passar, eu não vou estar vinculado totalmente à tv sã.

L: Essa questão de estágios, eu percebo uma coisa. Eu trabalhava numa instituição de ensino há um tempo e pegava muita amizade com os estagiários. Hoje a gente só se fala pelo whatsapp. Todos se formaram já, estão fazendo pós-graduação, dando aulas, estão com condições às vezes melhores do que eu. Eu também cheguei a concluir a faculdade, graças a Deus, conclui esse ano e... Em questão da saúde mental lá no CAPS, por exemplo, os estagiários e estagiárias pegam amizade com todos os pacientes e a gente acaba tendo um momento de se despedir porque fica um semestre, 2 anos no máximo. Chega aquele momento de despedida todo mundo fica triste, chateado, vamos ter que sair daqui... Hoje eu vi uma ex-estagiária do CAPS, ela está fazendo estágio em outro hospital, mas de vez em quando ela passa lá de volta. Teve festa junina no hospital, ela foi lá prestigiar a festa, está sempre envolvida com os trabalhos do CAPS de novo. Vai lá de forma voluntária mesmo. Então, eu acho que aqui na tv sã, não sei se tem os estagiários ainda, que agora que eu estou conhecendo mesmo, mas se tivesse, voltariam porque é uma área que todo mundo se encanta, a área da saúde, principalmente da saúde mental. As pessoas acabam pegando amizade uns com os outros.

P: A saúde mental às vezes pode trabalhar assuntos tensos, mas aqui parece haver muita leveza... chega ser até uma arte.

R: (risos) Complicado, é russo, tem de tudo, ne? Tem que estudar um pouco porque senão não vai pra frente. Os melhores salários hoje em dia, que você vê no jornal, você nem acredita, você acha que é mentira. De uma pessoa formada que tem 15 anos, 20 anos de estudo, que tem entre 10mil, 15 mil, 8 mil. (simultaneamente M: Mais!) 
Uma pessoa pra passar um mês com aquela grana. Porra, "15 pau" por mês, se descuidar perde o emprego.

H: Deixa eu só recapitular... Era sobre o negócio sobre as pequenas ONGs, pequenas ideias, que são coisas que mobilizam sociedades inteiras. Até na questão da roupa, da moda. Um se veste de um jeito e chama a atenção de um, de um, de outro e vira aquela epidemia, aquela coisa descomunal. Essas pequenas mobilizações assim, geram revoluções. De nego bater panela e derrubar 2 governos. É muito forte... Voltando a questão da cura... Parece um assunto novo, mas não é, cara. Desde os xamãs (risos) usavam vários tipos de coisas de trabalhos emocionais, espirituais e químicos com o corpo e mente. É coisa das antiguidades, sabe? Eu acho que a galera não investe ou não acredita na capacidade de ser curado, que existem os recursos, as possibilidades pra trazer essa benfeitoria. Parece que a sociedade que a gente vive está condicionada a sair dos seus problemas rápido: "estou em depressão, aí fudeu, agora vou tomar o meu remédio antidepressivo", sendo que a pessoa já guarda aquele problema há anos, debilidades emocionais e tal. Só que falta um empenho, uma dedicação para a pessoa reverter aquele quadro que é tudo uma grande estratégia da consciência, da estrutura, da força de vontade, e a pessoa se apoia na questão da psiquiatria, da medicina e da constituição, sendo que ela tem em si mesmo o potencial da cura, da reversão de qualquer problemática subjetiva que a pessoa tiver.

P: Nossa sociedade faz com que esse potencial seja....(simultaneamente H: ofuscado).

$\mathrm{H}$ : A sociedade ofusca esse potencial, ela veda, camufla. Quem tem o recurso vai pro hospital brasília e tal e tem um atendimento, mas quem não tem o recurso, a disponibilidade, vai pro hospital de base, "Você não quer cura? Então é isso mesmo!". Então assim, eu estou na tv sã (risos) por que eu acredito na cura. Eu posso oferecer, não de mim mesmo, tão somente, claro que um pouquinho não faz mal (risos). Eu tenho a oferecer possibilidades de ajudar. A tv sã pode ser um trampolim para divulgação, para um alerta, não somente na área da cura interior, subjetiva, potencial inerente da pessoa, mas a tv sã pode abordar diversas áreas voltadas para a saúde mental: do direito, da questão do preconceito, da inclusão, da inserção social, tanta coisa. É um trampolim pra muita coisa. Eu pessoalmente, Henrique, estou aqui pela cura psíquica total, geral, ascenção. Ascenção, agora é minha.

P: Queria ouvir num nível pessoal também para os outros participantes. Quer falar (Rodrigo)?

R: Eu gosto, a pessoa sair um pouco de casa, por exemplo, ir pro shopping, passear no shopping, dar uma volta, ver as promoções. Chegar e dizer pra mãe, "Pô mãe, eu vi um tênis, a coisa mais linda, eu vi isso vi aquilo" (risos) Aí vira uma bola de neve, ne? Mas tem muita coisa boa. Ir no shopping passear, com a pessoa que você conheça, uma pessoa que você tem mais afinidade, vai dar certo. Dar uma volta, aí toma um guaranazinho, vai na rodô, toma uma guaraná, sai abastecido.

P: Por exemplo, você já foi na unb mostrar o vídeo da tv sã...

R: Vai na unb, tem a biblioteca da unb, tem não sei quantos livros, é uma tranquilidade aquele lugar, super tranquilo, dá pra estudar, né mãe? Unb, unb, novela, de vez em quando é bom. 
P: Eu assisti um documentário que se chama Tarja Branca que fala sobre o brincar. No filme fala que o brincar é uma coisa muito séria, porque quando a gente brinca, a gente está por inteiro, a gente afirma a vida, se expressa. Como a Fabi falou, a gente fica com os movimentos amarrados.

L: Lá no CAPS uma vez, eu lembro até hoje de um dia que teve uma terapia que a gente falou, sempre na sexta-feira a gente fala como que foi a semana. A primeira vez que a gente começou a falar disso, geralmente as pessoas levaram muito os problemas que tinham. Eu também os problemas que eu tinha e eu saí com um peso. As pessoas disseram que saíram mais leves, eu saí muito carregado, com um peso maior ainda porque aquilo foi pra mim uma coisa muito dolorosa, colocar as coisas que eu tava sentindo. Se fosse um dia, por exemplo, de contar piadas, eu sairia bem mais feliz e não sairia com esse peso todo que eu saí nesse dia. Hoje eu estou habituado já, isso se tornou uma rotina praticamente.

\section{P: Qual é a sugestão que você deixa?}

L: Eu acho que poderiam mudar as rotinas. Por exemplo, o grupo hoje é uma roda de conversa, tá bom, vamos conversar sobre alguma coisa que anima, uma história alegre, uma história de superação, que não tenha coisas ruins, uma coisa só positiva. As pessoas vão pensar, se aquela história foi positiva, a minha história pode ser de coisas positivas.

Nem todo mundo tem $100 \%$ do tempo pra gente, as pessoas também precisam de tempo pra elas. Às vezes é $10 \%$ de tempo pra mim ou 1\% pra mim, 1\% pra outra pessoa. Assim como eu também tenho que ter tempo pra mim, eu não vou ter tempo pros meus pais, pra minha irmã o tempo todo, pras minhas amigas, meus amigos, porque eu tenho milhões de amigos e amigas, minha família é enorme também. Então não é possível ter tempo pra todo mundo. Se reunisse todas as pessoas que eu conheço num lugar só, ia virar uma bagunça enorme (risos) porque no meu perfil do facebook deve ter 2 mil pessoas, eu acho. Não dá pra juntar todo mundo num espaço só.

H: Tudo de bom, tudo de melhor possível. (risos) Esse negócio do pesar, por exemplo: eu costumo brincar muito com o meu surto, sacou? Quando eu comecei a surtar parecia um pesadelo que eu via na minha frente, aquela ratazana, aquela parada coisa... Hoje em dia eu dou risada das neuras que eu tive e tal. A gente tratar a saúde mental com espontaneidade, como que se não levasse a vida tão a sério, sabe? Tudo que você com rigor, com aquela regência militar traz um negócio negativo, cara. A gente fazer, por exemplo, sátiras do governo, fazer coisas bem humoradas e discutir com humor o lado mau, das trevas que rola dentro dos CAPS ou que rola dentro do HSVP. Não que seja motivo de piada, claro, mas tratar com naturalidade, com uma postura descontraída. Favorece mais do que você atirar pedra. Tem coisa que realmente você tem que apedrejar. (simultaneamente R: forçar um pouco, ne?) Assim, você está debatendo as coisas que acontecem no HSVP, aí você vai criticando ou apontando as falhas, os defeitos com uma austeridade muito grande, uma opulência, acaba que o rendimento da discussão vai ser inferior. Até porque a gente está aqui ne, a gente não está lá dentro internado, estamos construindo uma coisa objetiva, está lá fora. Com naturalidade, com espontaneidade, com senso de humor, é tudo de bom, é assim. Outra coisa: o luar noturno arrebata o pesar. 
L: Essa coisa que o Henrique falou sobre levar o problema que a gente tem na brincadeira, eu lembrei de uma vez que eu comentei com um amigo meu bem assim "ah, eu tenho alucinações". Aí ele falou "Nossa, deve ser muito massa ter alucinações, você está num lugar e vê uma pessoa que não existe e começa a conversar sozinho". (simultaneamente R: risos). Aí eu "É, é muito massa, é muito doido", mas eu fiquei constrangido por dentro um pouco constrangido com aquilo. Só que assim, outro dia, por exemplo, eu tive uma alucinação lá em casa, tinha uma pessoa tentando me matar e eu fiquei super desesperado, acordei até os vizinhos. Foram parar os bombeiros lá em casa, fui parar no hospital, não foi no HSVP, graças a Deus, mas eu passei a noite todinha no hospital depois do surto. Durante o surto eu não lembrava muita coisa que tinha acontecido. Eu lembro hoje só de uma parte do surto, do surto completo eu não lembro. Então assim, é uma coisa que as pessoas levam na brincadeira, mas na hora do problema ali, quando está acontecendo, é uma coisa de assustar. Não dá pra levar na brincadeira, é uma coisa de desespero. Minha mãe ficou desesperada, meu pai ficou desesperado, meu sobrinho de 8 anos ficou desesperado. Então, nem tudo é só brincadeira, mas tem que levar na brincadeira depois porque senão a gente acaba sofrendo o tempo.

\section{P: É possível ser crítico e brincar ao mesmo tempo?}

E: Ser crítico foi uma coisa que eu aprendi na Tv sã. Foi algo que desde o princípio a Tv Sã mostrou que é algo que nós devemos mostrar e cobrar porque muitos acham que só é um vídeo brincalhão. Mas ele não faz só brincadeiras, ele mostra exatamente a realidade do fato e ele mostra com crítica. Ao mostrar com crítica, muita gente não quer ver esse vídeo. Muitos funcionários de determinadas áreas do DF, eles estão com vergonha de assistir. Eu já percebi que o pessoal do CAPS de Samambaia não estão querendo assistir esse vídeo. Quando eu estive no evento em Samambaia que eu fui apoiar, eu percebi isso no olhar das funcionárias. Elas me olhavam como se eu estivesse sendo alguém que estivesse trazendo uma problemática muito grande pra eles. Como eles me viam como problema, eles não querem levar pro CAPS isso. A Laila ela ficou me olhando e falou pra mim, não falou pra outra pessoa "Você tem que pegar mais leve com as pessoas". Mas ela já sentiu isso porque eu isso eu já falei pra ela com 150 pessoas no público, os meninos assistindo. Ela falou algo que eu descordo na saúde mental, quando ela falou eu era o próximo a falar e eu disse "Laila, me desculpe, mas não é isso que eu vejo". Porque ela falou que o CAPS dela era o melhor CAPS de Brasília. Eu olhei pra ela assim, fechei os olhos, fiquei triste e falei pra ela "Desculpe, mas não é isso que eu vejo". No tempo sabe quem era a pessoa da recepção de la? Uma pessoa que não tem nenhum conhecimento, como se fosse um funcionário terceirizado. Ele tinha jeito de uma pessoa que não tinha conhecimento nenhum. Ele atendia as pessoas... Não foi coisa que eu ouvi falar. Eu fui no CAPS porque eu já tinha ouvido falar mal por uma pessoa que frequenta a Inverso, ela me falou das coisas que acontecem lá, eu peguei e resolvi visitar. Eu ia até me encontrar com ela esse dia e nem consegui encontrar com essa pessoa. Mas eu consegui ver os problemas do CAPS e ela ficou chateada a Laila porque eu vi o problema. Eu vi os meninos sendo atendidos por essa pessoa e o cara falava com eles com ignorância. Eu peguei olhei pra ele assim, me deu vontade de falar uma besteira pra ele, mas eu evitei (risos) pra ele não ficar tão triste. Os meninos reclamam, mas não vai uma pessoa fazer jus à reclamação dele. É como a gente sobre o CAPS de Taguatinga, o que a Laila fala pra gente: há reclamações, mas elas não chegam a ser efetuadas. 
P: A Tv Sã já mostrou em seus vídeos alguns depoimentos que mostram a realidade dos serviços, o mau atendimento, o despreparo da equipe...O vídeo excita alguma coisa nas pessoas?

E: A Tv Sã é acusadora mesmo, ela traz com acusação aquilo não estava servindo como base para o serviço público.

Mas faltam as pessoas "maturizarem" e pensar "nós precisamos melhorar". Se não tiver mais pessoas pra nos ajudar, nós não vamos conseguir ir dar a cara a tapa. Só que ninguém quer ir dar a cara a tapa, esse é o problema deles.

P: Então tem a dimensão da equipe que não quer ver as falhas e a dimensão das pessoas que fazem usam do serviço e não sabem dos direitos...

E: Exato. Ele não raciocina que está saindo do bolso dele o pagamento daquilo.

P: Por que as pessoas não sabem dos seus direitos?

E: É do jeito que eu falei daquela menina...

(simultaneamente)

M: Eu não acredito nisso das pessoas não saberem, porque quanto mais elas precisam, mas elas sabem. Quem sabe se não é a forma que elas tem pra serem agradáveis, pra elas conseguirem as coisas lá. Porque elas sabem de tudo que é direito e vão atrás bonitinho, então, pra serem agradáveis, pra conseguir muito coisa ali, ficam no lugar de vítima, de que não entende, mas no fundo entende. É como se fosse um teatro porque as pessoas que mais precisam, elas sabem, podem não saber $100 \%$, (simultaneamente E: mas aí é que está o problema), mas elas sabem. Ela está convivendo ali, sabe como é que é deficiente, atendimento e tudo, mas quando elas querem seus direitos elas chamam logo rede tal, jornalistas pra denunciar. Não estou querendo dizer que são todos os casos. Como o sistema ele é deficitário e as pessoas precisam, pelo menos, do mínimo necessário porque elas nem sempre elas tem condições de pra pagar porque é muito caro. Então elas ficam numa posição cômoda. Uma posição cômoda é aquela que, está do lado de cá, abraça, "meu amorzinho, meu benzinho, minha queridinha" que aí ela consegue tudo que ela precisar ali pra um filho, pra um parente pra alguém. Na hora que ela quiser ficar do lado de cá, ela pune, ela vai e denuncia. Só que denunciar é o mais difícil porque se ela denunciar, ela não tem mais. (simultaneamente E: mas aí é que está o problema) Por que o povo não denuncia os CAPS, a situação?

Eu estou dizendo isso porque eu trabalhei numa área muito carente que é o Varjão. Você vai numa casa muito humilde, quando chega lá é como se nada acontecesse. Ouve. Aí quando você sai, é outra realidade. Aquela família ali, se você não estiver bem atenta, aquela família que não precisava de certas coisas ela recebe ajuda de muitas outras entidades, mas não abre a boca. Você só fica conhecendo a partir da conversa com os vizinhos, que aí você começa a tirar suas conclusões. É tipo assim, um teatro. Não estou dizendo que é tudo $100 \%$.

P: Então algumas pessoas não sabem de seus direitos, outras sabem e tem medo...

M: É, porque são punidas. 
E: Muitas fazem isso, mas o problema não é ela ter coragem de falar. O problema é eles saberem que aquilo ali precisa ser, na verdade, exposto pra trazer conhecimento e mostrar para o profissional que ele não é o dono daquele local onde ele presta serviço.

M: Tem reclamar numa ouvidoria onde as pessoas não fazem parte porque ali sempre tem as pessoas que fazem parte. Porque se falar certas coisas a pessoa pode perder o cargo.

E: Mas ele não perde o cargo, muitas vezes ele sai daquela função ali e vai pra um outro local fazer o trabalho. Isso acontece com muitos profissionais, eles saem daquela função, daquela área ali e vai pra outra.

Eles (usuários) não tem coragem de falar exatamente por isso, porque parece que tem medo de perder aquele atendimento. O pensamento deles sobre o seu bem-estar não é lógico: "Eu não quero isso pra Fulano".... Eu vou dar um exemplo que mostra exatamente o que acontece: Eu cheguei no mercado, o nome do mercado é Dia-a-dia, minha prima faz compras lá. O que acontece? Cheguei, ela queria comprar algumas coisas e eu estava a fim de um queijo. Eu tinha dinheiro e poderia pagar naquele momento. Só que no queijo, pelo que estava escrito, foi muito engraçado. Estava escrito "R \$0,00". Eu peguei o queijo "Oxe, esse queijo está com a etiqueta errado". Eu não tive culpa, eu sou consumidor. Nos outros queijos estavam todos com o preço $\mathrm{R} \$ 13,90$. Eu olhei, vi o queijo e pensei "Esse queijo está de graça, vou levar esse queijo". A lei do consumidor me dá esse direito. (simultaneamente M: Mas tá errado!). Mas aí é que está, a lei me dá esse direito! Eu fui lá, peguei o queijo e levei no caixa. A menina quis passar e apareceu o preço de $\mathrm{R} \$ 13,90$. Aí eu falei pra ela "Pode chamar o gerente pra mim, por favor". A minha prima tinha passado no caixa antes de mim, ela pegou as coisas que ela tinha comprado, não ficou perto de mim. Se eu te disser que ela não comeu do queijo (risos)... Chegou o gerente e eu falei "Amigo, esse queijo está com o preço zerado. Eu quero esse queijo". Aí ele olhou pra mim e falou "Ah, eu vou te dar esse queijo". Eu disse "Não, não! Você não vai me dar. A lei está dizendo que você tem a obrigação de me repassar ele porque vocês erraram. Eu não errei, eu sou consumidor. Perante a lei eu estou correto". simultaneamente M: Nas instituições você reclama, mas não adianta reclamar). Eu ainda vou te dizer algo: a cunhada dela (irmã) chegou lá com meu outro primo, eu tive que levar na casa da minha outra prima porque eles não tiveram coragem! O que acontece, ela falou que os filhos dela, filhos dessa minha prima, pegaram num estabelecimento grande como o Extra, viram o preço de 2 reais num determinado condicionador e trouxeram pra casa. Só que o preço não era esse, estava lá na hora.

L: Essa história aí dos preços, eu me lembrei de quando eu trabalha com cartão de crédito. Eu vendia um cartão de crédito que não tinha anuidade, ia totalmente gratuito pro cliente, só que tinha uns serviços, de sms, um monte de coisas. Aí ia cobrando 1,99 por um, 2,99 por outro serviço, 5,99, o seguro de perda do cartão. Aí tinham os preços que iam cobrando na fatura depois, mesmo que o cliente não fosse usar o cartão. O cliente pagava sem saber porque estava pagando.

Aí sobre a questão da denúncia, do não denunciar, eu lembrei do HSVP. Quando eu estava lá, tinham muitas pessoas que dizem, "eu estou aqui porque preciso relaxar, aqui é uma clínica de relaxamento". Aqui é uma clínica psiquiátrica, clínica de relaxamento é um spa, é bem diferente. Lá a gente não tinha acesso à televisão, à informação, não tinha rádio. Às vezes eles botam um rádio chiando, botava qualquer música tocando pra gente fingir que tava se divertindo. Botava pra dançar forró, mas 
não tinha nem como dançar com o tanto de homem que tinha lá. Ficava um dançando com o outro ali, era uma vergonha, eu não ia dançar com outros homem. A gente não sabe o que está se passando lá fora. Raramente a gente ia pra televisão, numa outra área lá, as vezes de tanto o pessoal mudar de canal, dava defeito. E assim, ninguém nunca denunciou um tipo de serviço totalmente precário que é lá. Lá não é limpo, a maior parte do tempo é sujo, comida no chão...e é um hospital. Ninguém nunca denunciou, sempre estão acreditando que lá é um paraíso. Por que não denuncia, essa é a minha dúvida.

M: As pessoas que passaram por lá pra denunciarem, é muito arriscado.

L: É, pra denunciar eu preciso ter fotos, vídeos, essas coisas.

P: E não pode filmar lá...

M: É, não pode entrar nada.

L: As únicas pessoas que podem entrar com o celular são os profissionais de lá. E eles não vão querer fotografar...

Após finalizar entrevista, Elias começa a contar uma história e eu solicito a permissão para gravar novamente.

E: Como eu ando na maioria das vezes? Sempre de camiseta bem arrumada e de calça jeans e tênis. Quando eu ando assim, eles ficam me olhando como se eu fosse uma pessoa, mesmo com a carteirinha. Eles não me olham como se eu tivesse problema, eles até ficam chateados quando eu passo. Agora, hoje eu peguei e coloquei essa camiseta, vesti uma calça jeans e fui. Cheguei lá o cartão não passou. O que eu quero te dizer, quando eu estou com uma aparência como o que eles acham ser uma pessoa que tenha qualquer problema, eles me tratam e querem me dar o direito de sair pela frente como qualquer pessoa que tenha problema. Mas se eu tivesse de camiseta social, calça jeans como eu gosto de andar, e estivesse vindo pra Inverso, com certeza eles ficavam me olhando e não deixariam passar, como já aconteceu. A aparência eles ficam olhando e muito. Foi uma das coisas que eu fiquei prestando atenção hoje na hora que eu estava vindo pra cá.

L: Essa questão da aparência, por exemplo, eles acham que a deficiência é só física, ou falta um braço ou uma perna. Às vezes a pessoa pode ser cega, ter algum problema de saúde mental, pode ser surda. Minha irmã, por exemplo, tem deficiência auditiva e não dá pra ver. Eu não vou andar com uma camisa de força porque eu tenho algum transtorno bipolar, por exemplo.

P: A blusa do Elias está escrita "luta antimanicomial", as pessoas sabem o que é isso?

L: É, eu também não tinha nem ideia o que era isso antes.

E: Mas minha camisa é simples, esse é o problema. As pessoas não sabem o que é luta antimanicomial. Esse é o maior problema deles, eles não sabem nada e ninguém leva eles informação sobre isso. 
P: As mídias passam o que sobre saúde mental?

E: Eles passam que você é uma pessoa ruim e que você tem que viver trancafiado, esse é o propósito da mídia. Se você olhar o que a mídia faz, é como faz com a pessoa que tem problema de álcool e outras drogas. Eles querem pegar essa pessoa e afastar da sociedade porque ela não é adequada a viver no meio social. É o pensamento deles. 
ANEXO 4

Tabela 1 - Discurso do Sujeito Coletivo 1

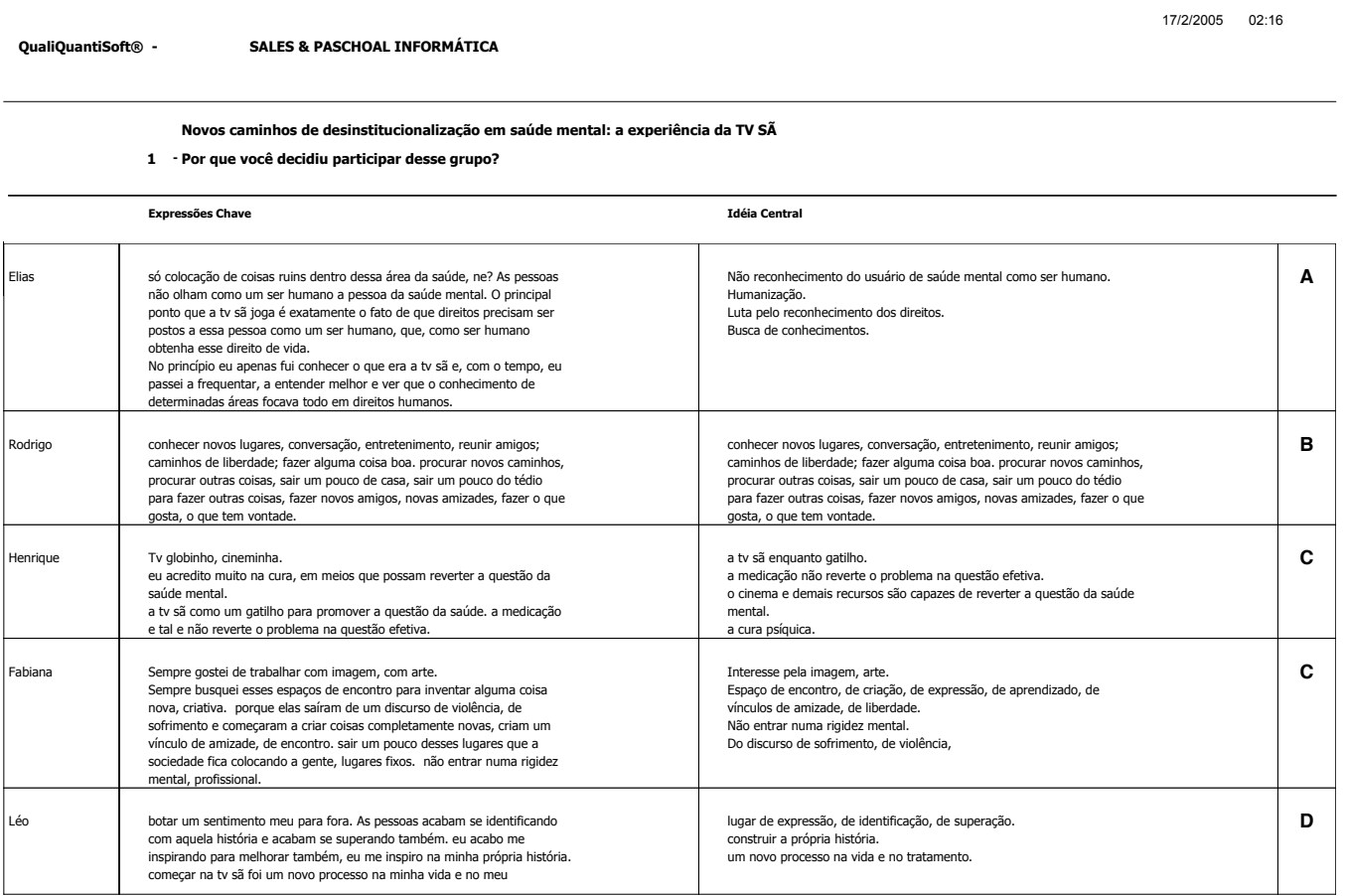

\section{Tabela 2 - Discurso do Sujeito Coletivo 2}

QualiQuantiSoft巴

SALES \& PASCHOAL INFORMÁTICA

Novos caminhos de desinstitucionalizaç̃o em saúde mental: a experiência da TV SÃ

2 - Por que trazer esse debate para o público por meio de vídeos?

\begin{tabular}{|c|c|c|c|}
\hline & Expressöes Chave & Idéia Central & \\
\hline Rodrigo & $\begin{array}{l}\text { Vai aumentando, vai proliferando, é uma bola de nevere é uma bola de } \\
\text { neve. As coisass vão fluindo, vai tudo dando certo, vai tudo entrando nos } \\
\text { conformes, vai tudo se ajeitando. As vezes pode certo, às vezes pode dar } \\
\text { errado, às vezes pode proliferar, às vezes pode atrapalhar. }\end{array}$ & Levar o debate para mais pessoas. & A \\
\hline Henrique & 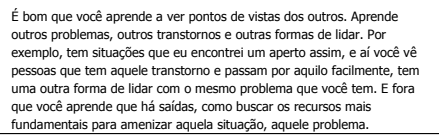 & $\begin{array}{l}\text { compartilihar experiências semelhantes e encontrar novos recurros para } \\
\text { superar as dificuldades }\end{array}$ & B \\
\hline Elias & $\begin{array}{l}\text { O maior problema nosso é a aceitação. O que acontece com a mídia hoje } \\
\text { em dią A mídiajogag pra você como se você fosse obrigado a aceitar tudo } \\
\text { o que ela está mostrando. }\end{array}$ & $\begin{array}{l}\text { Tornar público outros modos de ver a saúde mental. } \\
\text { Democratizar a midia. }\end{array}$ & c \\
\hline
\end{tabular}


Tabela 3 - Discurso do Sujeito Coletivo 3

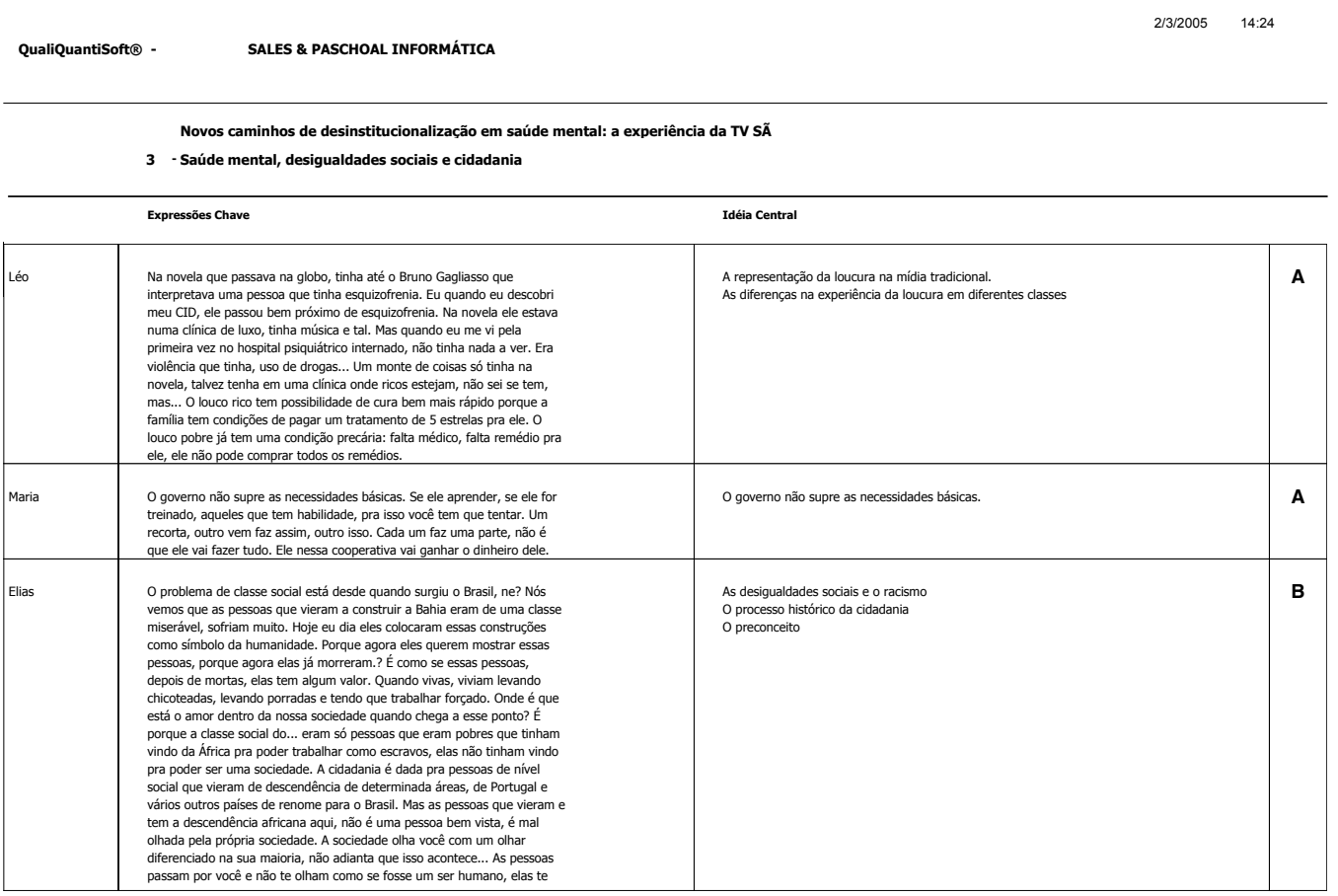

Tabela 4 - Discurso do Sujeito Coletivo 3.2

2/3/2005 $\quad 14: 24$

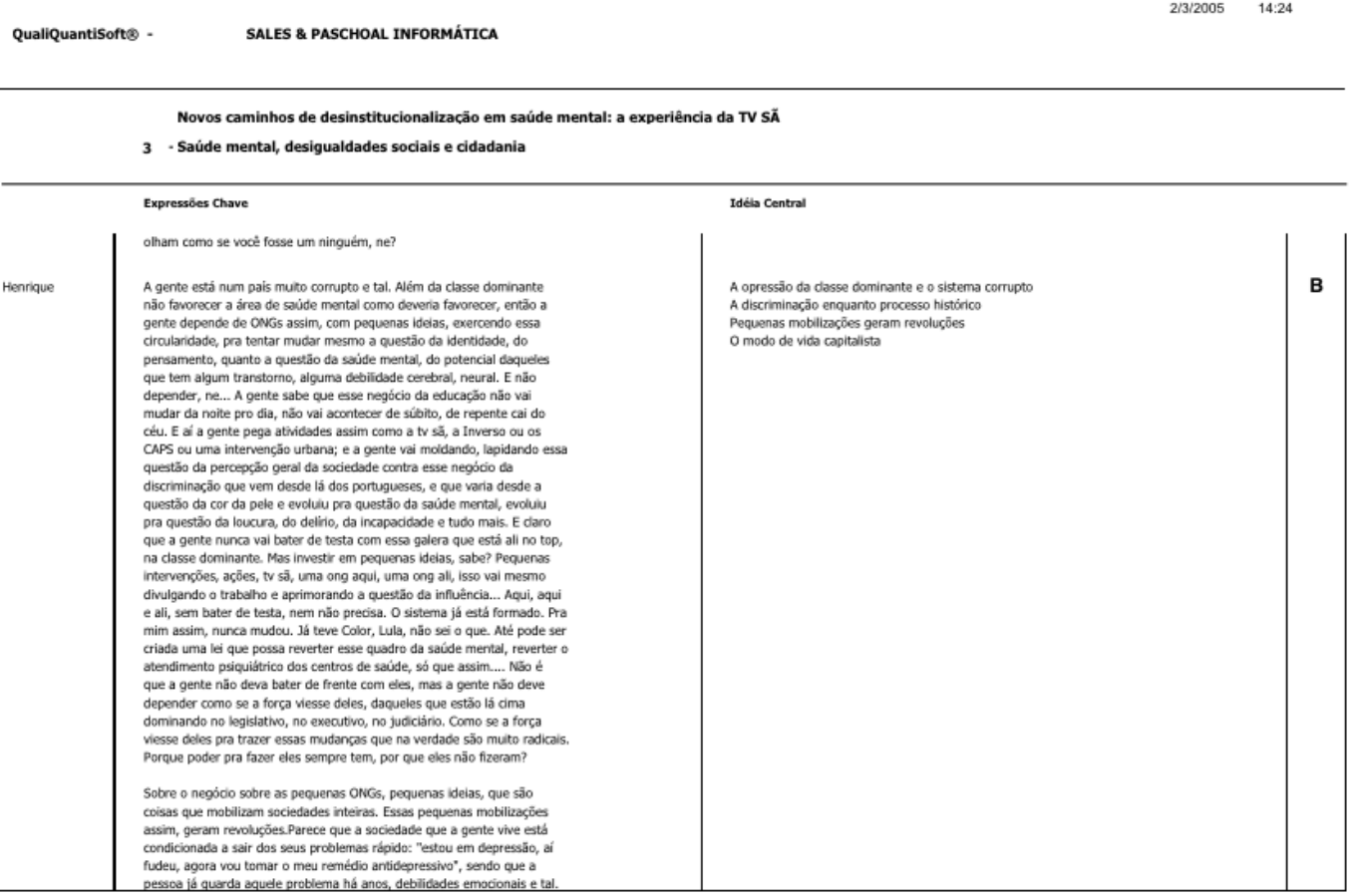


Tabela 5 - Discurso do Sujeito Coletivo 3.3

QualiQuantiSofti - SALES \& PASCHOAL INFORMÁTICA

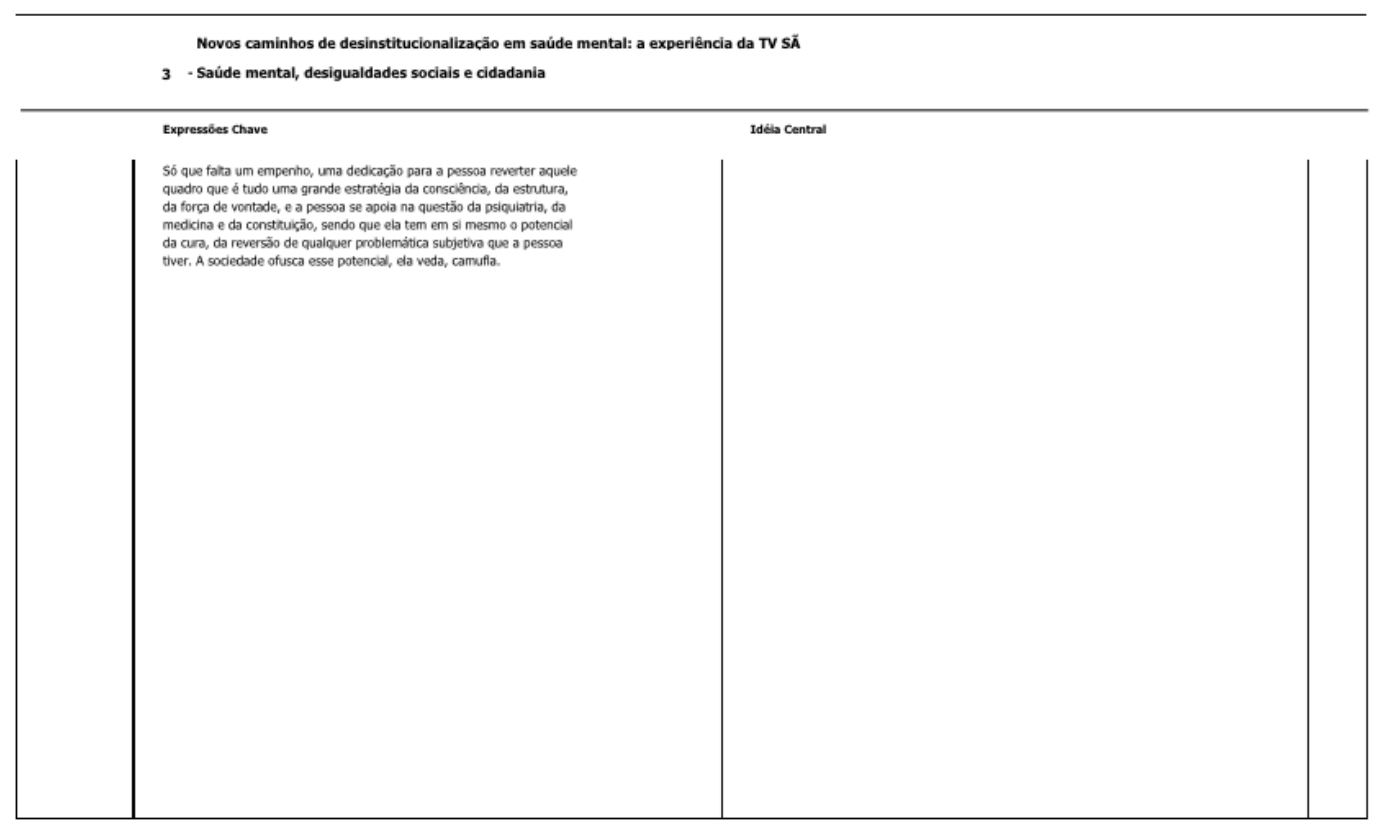

Tabela 6 - Discurso do Sujeito Coletivo 4

QualiQuantiSoft' - SALES \& PASCHOAL INFORMÁTICA

\begin{tabular}{|c|c|c|c|}
\hline \multicolumn{4}{|c|}{$\begin{array}{l}\text { Novos caminhos de desinstitucionalizacão em saúde mental: a experiência da TV SĂ } \\
4 \text { - Perspectivas para um futuro breve }\end{array}$} \\
\hline & Expresšbes Chave & Ideila Central & \\
\hline Elas & 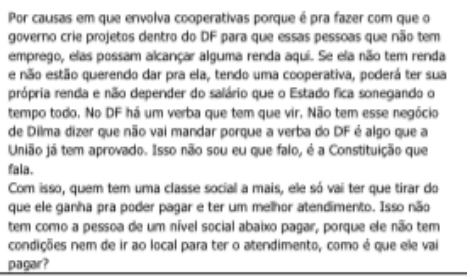 & $\begin{array}{l}\text { Criaçāo de cooperativas, empregabilidade e renda paro os usuarios de } \\
\text { saúde mental. } \\
\text { lguais condiçöes de atendimento ds differentes dasses. }\end{array}$ & A \\
\hline Leto & 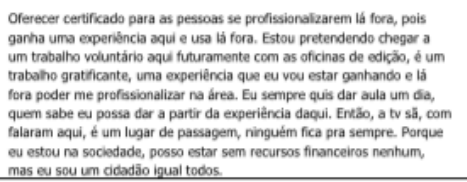 & 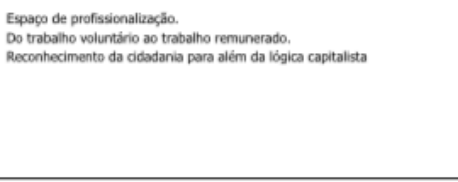 & A \\
\hline Maria & 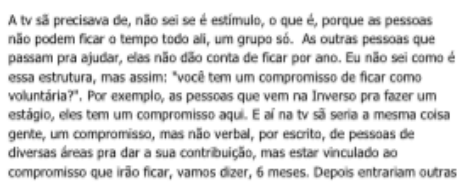 & 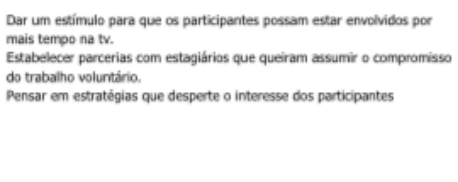 & B \\
\hline
\end{tabular}


Tabela 7 - Discurso do Sujeito Coletivo 4.2

17/2/2005 01:08

QualiQuantiSoft@ - $\quad$ SALES \& PASCHOAL INFORMÁTICA

Novos caminhos de desinstitucionalizaçăo em saúde mental: a experiência da TV SÃ

4 - Perspectivas para um futuro breve

\begin{tabular}{|c|c|c|c|}
\hline & Expressibes chave & Idelia Central & \\
\hline & 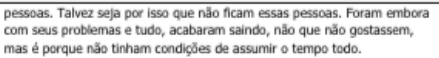 & & \\
\hline Fabliana & 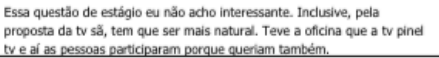 & Estabelecer parcerias com diversas pessoas, sem burocracias. & B \\
\hline Henriaue & 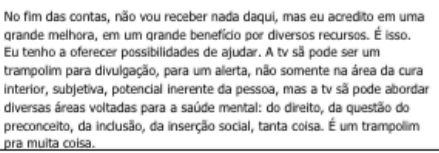 & 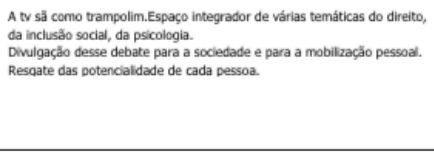 & c \\
\hline Rodrigo & 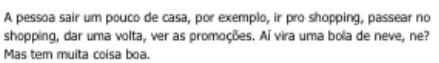 & Espaço de laze, de "tazer colsas boas". & D \\
\hline
\end{tabular}

Tabela 8 - Discurso do Sujeito Coletivo 5

QualiQuantiSoft $\circledast$ - $\quad$ SALES \& PASCHOAL INFORMÁTICA

Novos caminhos de desinstitucionalização em saúde mental: a experiência da TV SÃ

5 - Espaço lúdico, debate sério

\begin{tabular}{|c|c|c|c|}
\hline & Expressōes Chave & Idéia Central & \\
\hline Henrique & 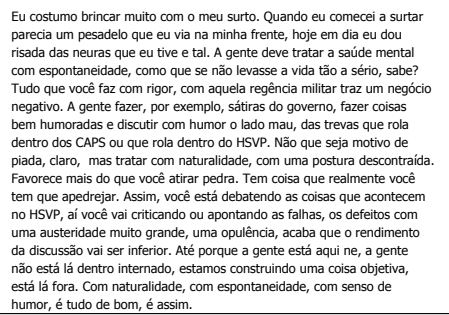 & $\begin{array}{l}\text { Abordar os temas com mais leveza, mas de forma séria } \\
\text { o humor como recurso para superar o soffrimento }\end{array}$ & A \\
\hline Elias & 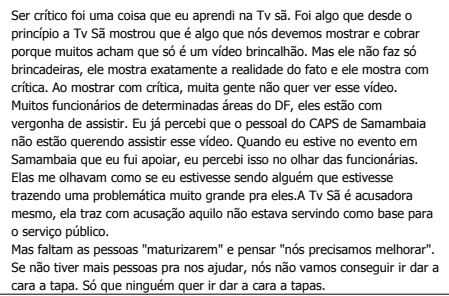 & $\begin{array}{l}\text { Teor critico nos vídeos. } \\
\text { Coragem daqueles que participam com seus depoimentos. }\end{array}$ & B \\
\hline
\end{tabular}


Tabela 9 - Discurso do Sujeito Coletivo 5.2

QualiquantiSoft@ - $\quad$ SALES \& PASCHOAL INFORMÁTICA

Novos caminhos de desinstitucionalizaç̃o em saúde mental: a experiência da TV SÃ

5 - Espaço lúdico, debate sério

\begin{tabular}{|c|c|c|c|}
\hline & Expresső̈es Chave & Idéia Central & \\
\hline Léo & 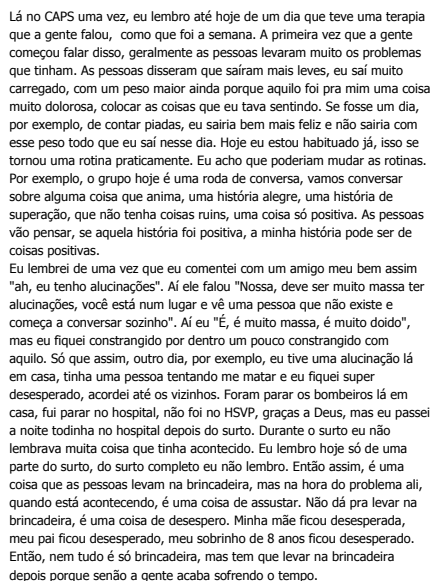 & $\begin{array}{l}\text { Mudanca nas rotinas das instituicōos. } \\
\text { Promoção de rodas de conversa, compartilhamento de histórias de } \\
\text { superação } \\
\text { O humor como um recurso para superar o sofrimento }\end{array}$ & A \\
\hline
\end{tabular}




\section{ANEXO 5 \\ Discurso do Sujeito Coletivo das Idéias Centrais}

\section{1 - Por que você decidiu participar desse grupo?}

A) As pessoas não olham como um ser humano a pessoa da saúde mental. O principal ponto da tv sã é mostrar exatamente a importância de que os direitos precisam ser postos a essa pessoa, como qualquer ser humano que tem direito de vida.No princípio eu apenas fui conhecer o que era a tv sã e, com o tempo, eu passei a frequentar, a entender melhor e ver que o conhecimento de determinadas áreas focava todo em direitos humanos.

B) Tem a ver com conversação, entretenimento, fazer alguma coisa boa, procurar novos caminhos. Conhecer novos lugares, reunir amigos, sair um pouco de casa, sair um pouco do tédio para fazer outras coisas, fazer novos amigos, fazer o que gosta, o que tem vontade. São caminhos de liberdade.

C) Eu acredito em meios que possam reverter a questão da saúde mental já que só a medicação não é efetiva. Sempre busquei esses espaços de encontro para inventar alguma coisa nova, criativa, não entrar numa rigidez mental, profissional. Trabalhar com imagem, com arte, sair um pouco desses lugares que a sociedade fica colocando a gente, lugares fixos. A Tv Sã pode ser um gatilho para promover a questão da saúde mental.

D) Começar na tv sã foi um novo processo na minha vida e no meu tratamento. Colocar um sentimento meu para fora, as pessoas acabam se identificando com aquela história e acabam se superando também. Eu acabo me inspirando para melhorar também. Eu me inspiro na minha própria história.

\section{2 - Por que trazer esse debate para o público por meio de vídeos?}

A) Vai aumentando, vai proliferando, é uma bola de neve. As coisas vão fluindo, vai tudo dando certo, vai tudo entrando nos conformes, vai tudo se ajeitando. Às vezes pode certo, às vezes pode dar errado, às vezes pode proliferar, às vezes pode atrapalhar. 
B) É bom que você aprende a ver pontos de vistas dos outros. Aprende outros problemas, outros transtornos e outras formas de lidar. Por exemplo, tem situações que eu encontrei um aperto assim, e aí você vê pessoas que tem aquele transtorno e passam por aquilo facilmente, tem uma outra forma de lidar com o mesmo problema que você tem. E fora que você aprende que há saídas, como buscar os recursos mais fundamentais para amenizar aquela situação, aquele problema.

C) O maior problema nosso é a aceitação. O que acontece com a mídia hoje em dia? A mídia joga pra você como se você fosse obrigado a aceitar tudo o que ela está mostrando.

\section{3 - Saúde mental, desigualdades sociais e cidadaniaA - As desigualdades sociais}

A) O louco rico tem possibilidade de cura bem mais rápido porque a família tem condições de pagar um tratamento de 5 estrelas pra ele. O louco pobre já tem uma condição precária: falta médico, falta remédio pra ele, ele não pode comprar todos os remédios. O governo não supre as necessidades básicas.

B) O problema de desigualdade social está desde quando surgiu o Brasil, ne? Nós vemos que as pessoas que vieram construir a Bahia eram de uma classe miserável, sofriam muito. Hoje eu dia eles colocaram essas construções como símbolo da humanidade. Porque agora eles querem mostrar essas pessoas, porque agora elas já morreram? Quando vivas, levavam chicoteadas, porradas, tendo que trabalhar forçado. Eram só pessoas que eram pobres que tinham vindo da África pra poder trabalhar como escravos, elas não tinham vindo pra poder ser uma sociedade. Onde é que está o amor dentro da nossa sociedade quando chega a esse ponto? A cidadania é dada pra pessoas de nível social, com descendência de determinada áreas, como de Portugal e vários outros países de renome para o Brasil. Mas as pessoas que vieram e tem a descendência africana aqui, não é uma pessoa bem vista, é mal olhada pela própria sociedade. A sociedade olha você com um olhar diferenciado, não te olham como se fosse um ser humano, elas te olham como se você fosse um ninguém, ne? Esse negócio da discriminação que vem desde lá dos portugueses, e que varia desde a questão da cor da pele e evoluiu pra questão da saúde mental, evoluiu pra questão da loucura, do delírio, da incapacidade e tudo mais. Se em pouco mais de 500 anos não 
mudou muita coisa que deveria ter mudado, não vai mudar da noite pro dia também ne? Não vai acontecer de súbito, de repente cai do céu.A gente está num país muito corrupto e tal, a classe dominante não favorece a área de saúde mental como deveria favorecer. Até pode ser criada uma lei que possa reverter esse quadro da saúde mental, reverter o atendimento psiquiátrico dos centros de saúde, só que assim...O sistema já está formado. A gente não deve depender como se a força viesse deles, daqueles que estão lá cima dominando no legislativo, no executivo, no judiciário. Como se a força viesse deles pra trazer essas mudanças que na verdade são muito radicais. Porque poder pra fazer eles sempre tem, por que eles não fizeram? Então a gente depende de ONGs assim, com pequenas ideias, exercendo essa circularidade, pra tentar mudar mesmo a questão da identidade, do pensamento, quanto a questão da saúde mental, do potencial daqueles que tem algum transtorno. E aí a gente pega atividades assim como a tv sã, a Inverso ou os CAPS ou uma intervenção urbana; e a gente vai moldando, lapidando essa questão da percepção geral da sociedade contra a discriminação. Pequenas intervenções, ações, uma aqui, uma ali, isso vai mesmo divulgando o trabalho e aprimorando a questão da influência. que são coisas que mobilizam sociedades inteiras. Essas pequenas mobilizações assim, geram revoluções. Parece que a sociedade que a gente vive está condicionada a sair dos seus problemas rápido: "estou em depressão, aí fudeu, agora vou tomar o meu remédio antidepressivo", sendo que a pessoa já guarda aquele problema há anos, debilidades emocionais e tal. Só que falta um empenho, umadedicação para a pessoa reverter aquele quadro que é tudo uma grande estratégia da consciência, da estrutura, da força de vontade, e a pessoa se apoia na questão da psiquiatria, da medicina e da constituição, sendo que ela tem em si mesmo o potencial da reversão de qualquer problemática subjetiva que a pessoa tiver. A sociedade ofusca esse potencial, ela veda, camufla.

\section{4 - Perspectivas para um futuro breve}

A) Oferecer certificado para as pessoas se profissionalizarem lá fora, pois ganha uma experiência aqui e usa lá fora. Estou pretendendo chegar a um trabalho 
voluntário aqui futuramente com as oficinas de edição, é um trabalho gratificante, uma experiência que eu vou estar ganhando e lá fora poder me profissionalizar na área. Eu sempre quis dar aula um dia, quem sabe eu possa dar a partir da experiência daqui. Além disso, é necessário que o governo crie projetos dentro do DF para que essas pessoas que não tem emprego, elas possam alcançar alguma renda aqui. Se ela não tem renda e não estão querendo dar pra ela, tendo uma cooperativa, poderá ter sua própria renda e não depender do salário que o Estado fica sonegando o tempo todo. No DF há um verba que tem que vir. Não tem esse negócio de Dilma dizer que não vai mandar porque a verba do DF é algo que a União já tem aprovado. Isso não sou eu que falo, é a Constituição que fala. Porque eu estou na sociedade, posso estar sem recursos financeiros nenhum, mas eu sou um cidadão igual todos.

B) A tv sã precisava de, não sei se é estímulo, o que é, porque as pessoas não podem ficar o tempo todo ali, um grupo só. As outras pessoas que passam pra ajudar, elas não dão conta de ficar por ano. Eu não sei como é essa estrutura, mas assim: "você tem um compromisso de ficar como voluntária?". Por exemplo, as pessoas que vem na Inverso pra fazer um estágio, eles tem um compromisso aqui. E aí na tv sã seria a mesma coisa gente, um compromisso, mas não verbal, por escrito, de pessoas de diversas áreas pra dar a sua contribuição, mas estar vinculado ao compromisso que irão ficar, vamos dizer, 6 meses. Depois entrariam outras pessoas. Talvez seja por isso que não ficam essas pessoas. Foram embora com seus problemas e tudo, acabaram saindo, não que não gostassem, mas é porque não tinham condições de assumir o tempo todo. Por outro lado, é interesse que as pessoas se aproximem de forma mais natural.

C) Eu acredito em uma grande melhora, em um grande benefício por diversos recursos. É isso. Eu tenho a oferecer possibilidades de ajudar. A tv sã pode ser um trampolim para divulgação, para um alerta, não somente na área da cura interior, subjetiva, potencial inerente da pessoa, mas a tv sã pode abordar diversas áreas voltadas para a saúde mental: do direito, da questão do preconceito, da inclusão, da inserção social, tanta coisa. É um trampolim pra muita coisa.

D) A pessoa sair um pouco de casa, por exemplo, ir pro shopping, passear no shopping, dar uma volta, ver as promoções. Aí vira uma bola de neve, ne? Mas tem muita coisa boa. 


\section{5 - Espaço lúdico, debate sério}

A) Eu costumo brincar muito com o meu surto. Quando eu comecei a surtar parecia um pesadelo que eu via na minha frente, hoje em dia eu dou risada das neuras que eu tive e tal. A gente deve tratar a saúde mental com espontaneidade, como que se não levasse a vida tão a sério, sabe? Nem tudo é só brincadeira, há o medo, o desespero, o constrangimento, mas tem que levar na brincadeira depois porque senão a gente acaba sofrendo o tempo.Tudo que você faz com rigor, com aquela regência militar traz um negócio negativo. A gente fazer, por exemplo, sátiras do governo, fazer coisas bem humoradas e discutir com humor o lado mau, das trevas que rola dentro dos CAPS ou que rola dentro do HSVP. Não que seja motivo de piada, claro, mas tratar com naturalidade, com uma postura descontraída. Favorece mais do que você atirar pedra. Tem coisa que realmente você tem que apedrejar. Assim, você está debatendo as coisas que acontecem no HSVP, aí você vai criticando ou apontando as falhas, os defeitos com uma austeridade muito grande, uma opulência, acaba que o rendimento da discussão vai ser inferior. Até porque a gente está aqui ne, a gente não está lá dentro internado, estamos construindo uma coisa objetiva, está lá fora. Com naturalidade, com espontaneidade, com senso de humor, é tudo de bom, é assim. Lá no CAPS uma vez, eu lembro até hoje de um dia que teve uma terapia que a gente falou, como que foi a semana. A primeira vez que a gente começou falar disso, geralmente as pessoas levaram muito os problemas que tinham. As pessoas disseram que saíram mais leves, eu saí muito carregado, com um peso maior ainda porque aquilo foi pra mim uma coisa muito dolorosa, colocar as coisas que eu tava sentindo. Se fosse um dia, por exemplo, de contar piadas, eu sairia bem mais feliz e não sairia com esse peso todo que eu saí nesse dia. Hoje eu estou habituado já, isso se tornou uma rotina praticamente. Eu acho que poderiam mudar as rotinas. Por exemplo, o grupo hoje é uma roda de conversa, vamos conversar sobre alguma coisa que anima, uma história alegre, uma história de superação, que não tenha coisas ruins, uma coisa só positiva. As pessoas vão pensar, se aquela história foi positiva, a minha história pode ser de coisas positivas.

B) Ser crítico foi uma coisa que eu aprendi na Tv sã. Foi algo que desde o princípio a Tv Sã mostrou que é algo que nós devemos mostrar e cobrar porque 
muitos acham que só é um vídeo brincalhão. Mas ele não faz só brincadeiras, ele mostra exatamente a realidade do fato e ele mostra com crítica. Ao mostrar com crítica, muita gente não quer ver esse vídeo. Muitos funcionários de determinadas áreas do DF, eles estão com vergonha de assistir. Eu já percebi que o pessoal do CAPS de Samambaia não estão querendo assistir esse vídeo. Quando eu estive no evento em Samambaia que eu fui apoiar, eu percebi isso no olhar das funcionárias. Elas me olhavam como se eu estivesse sendo alguém que estivesse trazendo uma problemática muito grande pra eles. A Tv Sã é acusadora mesmo, ela traz com acusação aquilo não estava servindo como base para o serviço público. Mas faltam as pessoas pensarem "nós precisamos melhorar". Se não tiver mais pessoas pra nos ajudar, nós não vamos conseguir ir dar a cara a tapa. Só que ninguém quer ir dar a cara a tapas. 